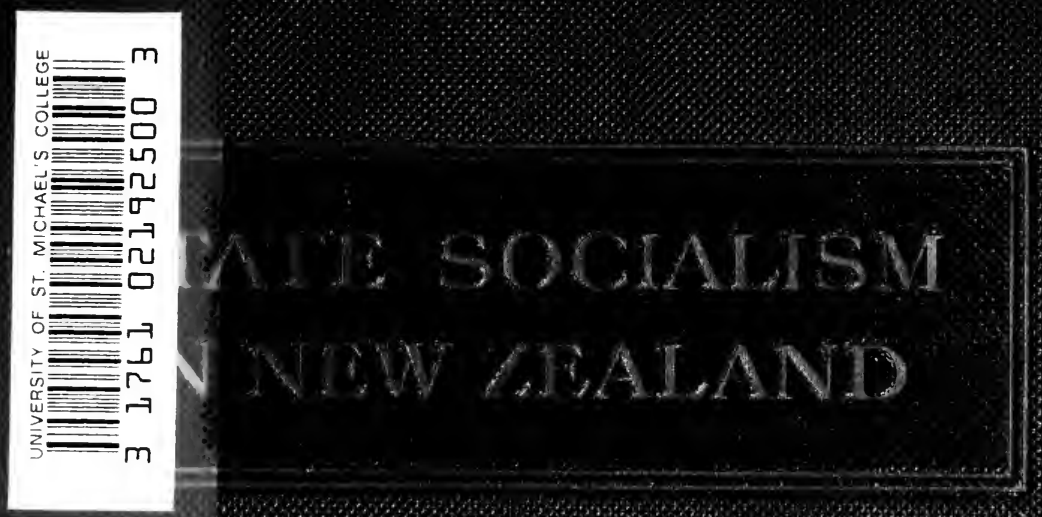

$\therefore$ Ho 



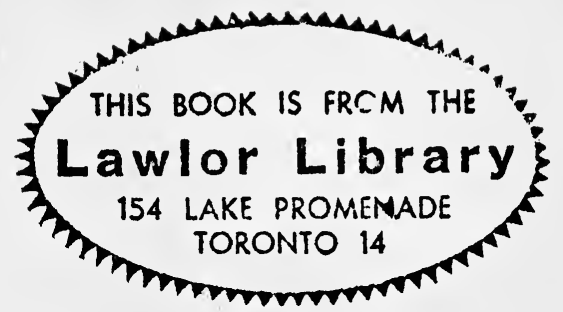




\section{Digitized by the Internet Archive in 2007 with funding from Microsoft Corporation}




\section{STATE SOCIALISM IN NEW ZEALAND}





\title{
STATE SOCIALISM IN NEW ZEALAND
}

BY

\section{JAMES EDWARD LE ROSSIGNOL}

PROFESSOR OF ECONOMICS IN THE UNIVERSITY OF DENVER

\author{
AND
}

WILLIAM DOWNIE STEWART

BARRISTER-AT-LAW, DUNEDIN, NEW ZEALAND

\section{LONDON}

GEORGE G. HARRAP \& COMPANY

9, Portsmouth Street, Kingsway, W.C. 


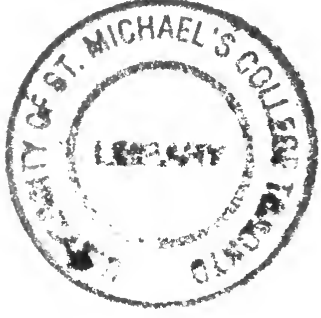


TO

\section{HENRY AUGUSTUS BUCHTEL}

CHANCELLOR OF THE UNIVERSITY OF DENVER SOMETIME GOVERNOR OF COLORADO 



\section{PREFACE}

IN giving a critical account of some phases of state activity in New Zealand, we have kept in mind the point of view of the foreign observer and that of the citizen of the Dominion who takes part in the discussion of public affairs. From the former point of view it is desirable that the workings of the various social experiments should be shown as they are, without exaggeration or concealment, if anything is to be learned of their success or failure, or any knowledge obtained that might be used in the cause of social reform in other countries.

From the latter point of view nothing is more important than the active discussion of public questions, for it is by this means that the conflict of interests results in compromise and legislation. But it is not enough to make a law and create a governmental department, for a department is no more to be trusted than a private corporation, and the struggle for good government must go on all the time, if abuses are to be corrected and the liberties of the people to be preserved.

It is well that members of Parliament and editors give time and thought to public questions; but manufacturers and merchants, farmers and labourers, and all the other classes must do the same, that no one set of interests be allowed to dominate the rest, and that all may work together for the common weal. In New Zealand, as elsewhere, most of the people are busy earning a living, and their leisure time is given to amusements of one kind and another, but there is an increasing number of good citizens who study the questions of the day, 
help to form public opinion and make democratic government possible. Still more might be accomplished if it were fully realized that the chief work of the schools and colleges is the training of citizens, and that the most important studies, after the elementary branches, are the new humanities: history, politics, economics, and sociology.

The chief authorities used in the preparation of this book have been government reports, parliamentary debates, and newspapers. Of the government reports, the most important are the excellent Year-Books, containing an enormous amount of information, and giving a fine statistical history from the year 1892. The best discussions of public questions are to be found in the Parliamentary Debates, and the newspapers also are very good, giving reliable news and excellent editorial articles. Of secondary authorities, by far the best are the admirable works of Mr. Reeves. The works of Lloyd and Parsons contain much information and interesting comment. The recent book by Mr. Scholefield, entitled "New Zealand in Evolution" and published by T. Fisher Unwin, is the best narrative of the industrial development of New Zealand. There is a conspicuous lack of monographs on special topics, although there is a vast, undeveloped field of research for University students and other investigators. The subject of industrial arbitration, however, has been carefully studied, and the works of Pigou, Gilman, Knoop, Clark, Broadhead, and Aves are especially valuable.

We desire to thank all those who have helped us in the preparation of this book, especially the Hon. Sir Robert Stout, the Hon. George Fowlds, the Hon. J. A. Millar, Consul-General William A. Prickitt, Professor Ernest Rutherford, Professor Frederick Douglas Brown, Mr. J. P. Grossman, Mr. Samuel Vaile, Mr. John MacGregor, 
Mr. Edward Tregear, Mr. E. J. von Dadelszen, and Mrs. Hastings Bridge. Particular thanks are due to Professor James Hight, of Canterbury College, who has read several of the chapters in manuscript and has made a number of valuable suggestions.

J. E. LE ROSSIGNOL.

W. D. STEWART. 



\section{CONTENTS}

CHAPTER

PAGE

I. The Functions of Government $\quad$ - $\quad$ - $\quad$ - 1

II. Land Tenure $\quad$ - $\quad$ • $\quad$ • $\quad$ • $\quad$ • $\quad$ • 20

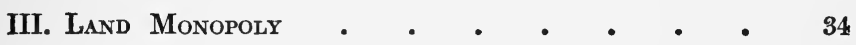

IV. Roads and Railways • • • • • • 52

V. Railway Finance • • • • • • • • 68

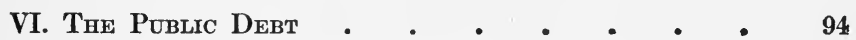

VII. The Land and Income Tax . • • • • 117

VIII. Local Taxation of Land . • • • • • 138

IX. State Life Insurance • • • • • • 153

X. State Fire Insurance • • • • • • 167

XI. Old Age Pensions •

XII. The Public Service - • • • • • 197

XIII. The Arbitration ACt • • • • • . . 216

XIV. Compulsory Arbitration in Theory and Practice 238

XV. Strikes . . . • • . • • • • 250

XVI. Wages And Cost of Living $\quad$ • $\quad . \quad . \quad$ • $\quad . \quad 269$

XVII. General Survey and Estimate of Results • • 284

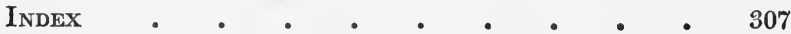



GrivalBn iatsion GWA 7ATE WJK

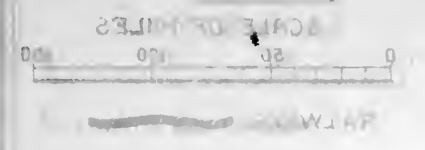




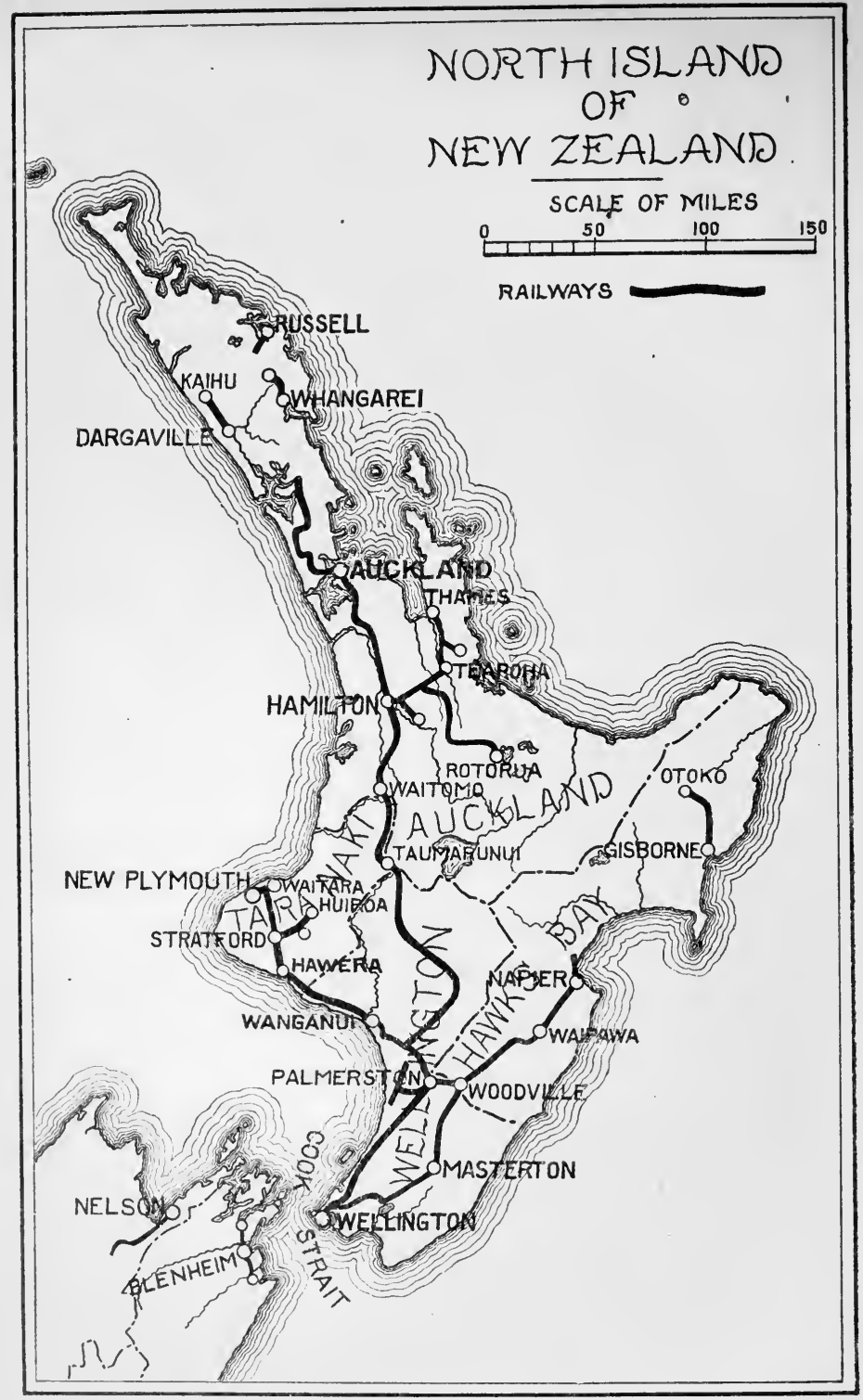




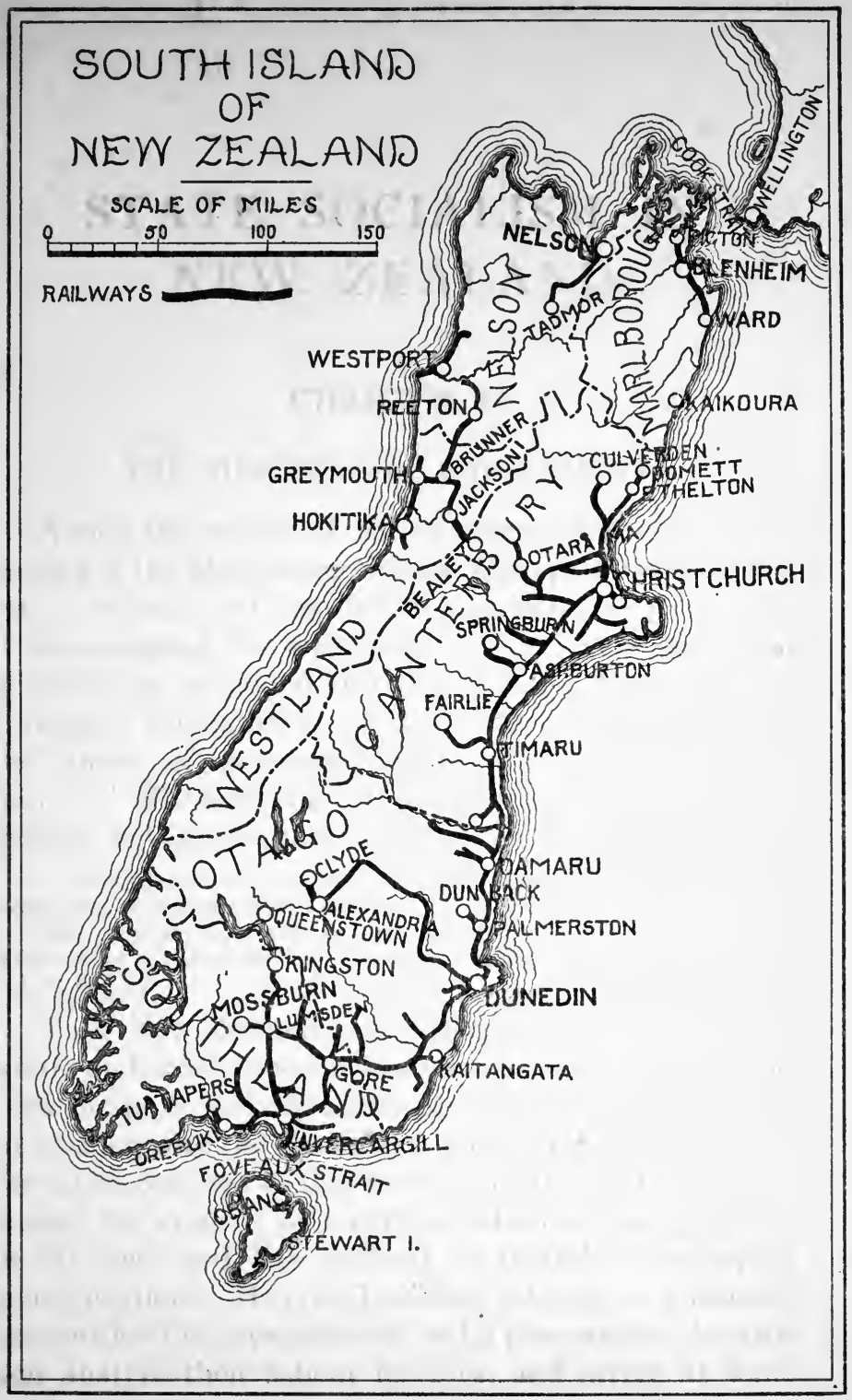




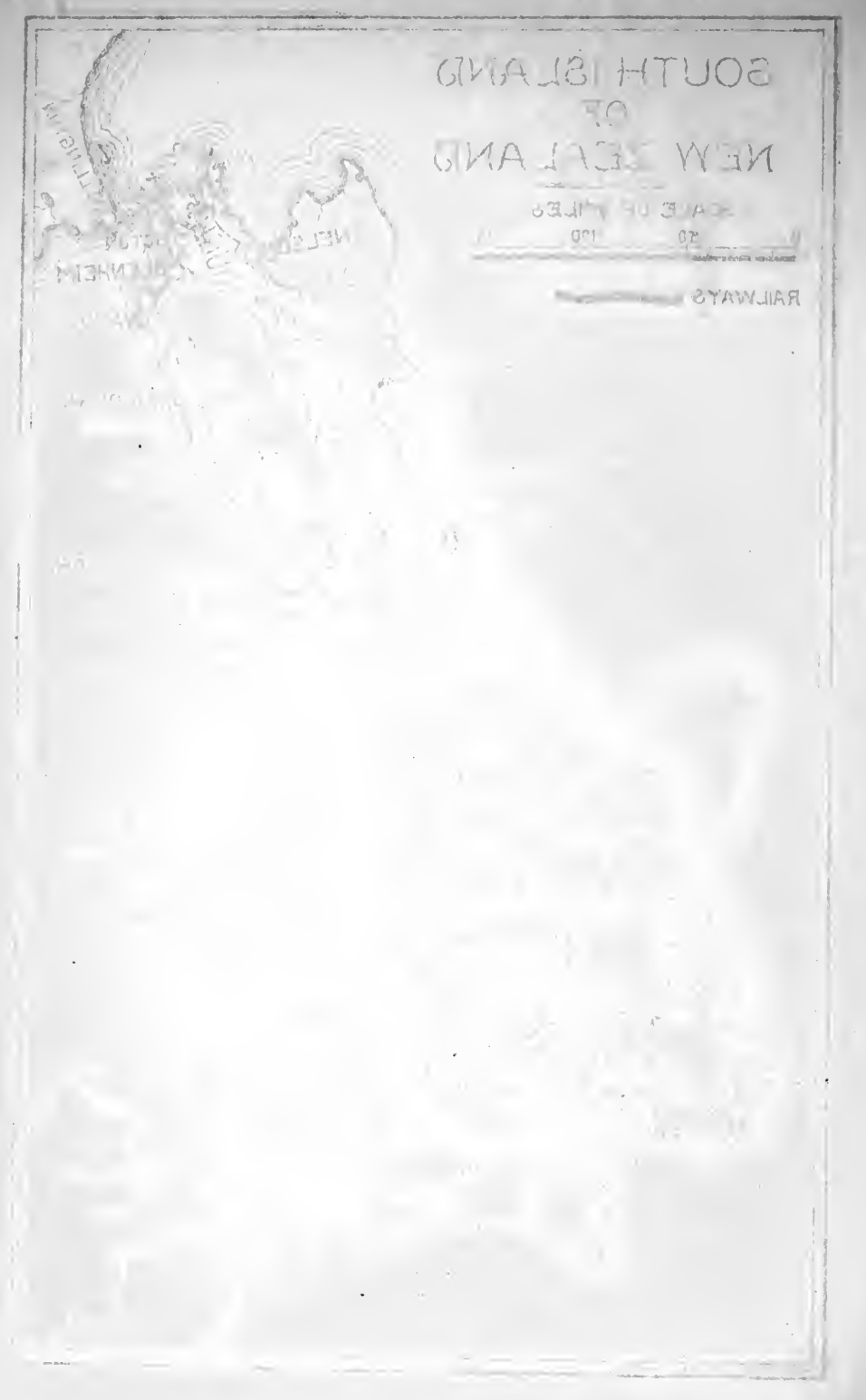




\section{STATE SOCIALISM IN NEW ZEALAND}

\section{CHAPTER I}

\section{THE FUNCTIONS OF GOVERNMENT}

Авоuт the middle of the nineteenth century, in the heyday of the Manchester School, when political economy was a science and free trade a gospel, it was common for writers on political The Policeman questions to propound theories of gov- Theory ernmental functions, to assign limits to the sphere of governmental activity, to say to the State: "Hitherto shalt thou come, but no further." Buckle, writing in 1858 , said:

"To maintain order, to prevent the strong from oppressing the weak, and to adopt certain precautions respecting the public health are the only services which any government can render to the interests of civilization." (" History of Civilization in England," vol. I, ch. 5.)

To a New Zealander of the present generation the words of Buckle sound like a voice from the tomb, and even the most individualistic American must be inclined to wonder why the State, like a policeman on his beat, should be confined to this narrow round of duties. Nowadays, the student of social evolution is less dogmatic in his tone and less inclined to indulge in sweeping generalizations. He is well satisfied if he can in a measure account for the appearance of social phenomena, describe and analyze their salient features, and arrive at some 
conclusions, more or less dubious, as to their apparent effects.

It is not easy to explain the causes which brought about the multifarious activities of the New Zealand Government. The settlers were chiefly Origin of State English, Scotch and Irish, like those Activities of British America in the early days, and

at the present time the canny Scot of Montreal and Pittsburg feels perfectly at home in Dunedin, the Canadian of Halifax and Toronto finds congenial friends in Auckland and Christchurch, and the American of New York can talk business and politics on an equal footing with the citizen of Wellington, even though they may not see eye to eye on all political and industrial questions. Since there is no essential difference between the New Zealander, on the one hand, and the Anglo-Saxon of the United States or Canada, on the other, the difference in regard to governmental functions must be due to differences in environment rather than in the character of the people.

Perhaps the early settlers, many of whom were brought out by the New Zealand Company and other associations, from I 840 onwards, had a sense of dependence which made them look to the Company, and, afterwards, to the State, to do things for them which the American settlers, unwilling to be taxed and unable to borrow, had to do for themselves. (Clark, "The Labour Movement in Australasia," pp. 34-39.)

And yet the settlers were, as a rule, enterprising and self-reliant people, the provinces were small and governed by the leading men, and the work of the provincial councils was the work of the settlers themselves, doing by means of associated activity what could not be done so well by individual effort. 
Indeed, for a number of years the provinces did not differ much from other colonies in regard to governmental enterprise. They administered the Crown lands, built roads, maintained Crown Lands schools, had their own police, and, although subject to the authority of the General Assembly, they carried on governments quite similar to those of the states of the Union or the provinces of Canada. The essential feature of the situation was that the provinces held and administered the Crown lands, and, like other landlords, were expected to make roads and otherwise improve their estates (Reeves, "State Experiments in Australasia and New Zealand," vol. I, p. 62). The settlers expected a good deal of such improvement, since the land was not given away, but sold at prices ranging from 5s. (\$r.25) an acre in Auckland to £2 (\$IO) an acre in Canterbury.

From the making of roads the provinces naturally passed to the building of railways. Railways, as well as roads, were needed for the development of the country, and yet they were not promising forms of investment for

Roads and

Railways private capital. Colonial capital was profitably employed in the exploitation of land and the commerce in wool, and British syndicates could not have been induced to build railways without large grants of land, which the people were unwilling to give. Only one course remained,- the provinces must borrow money and build railways themselves, and this they did. The first railway was begun by the Province of Canterbury in the year 1860 , and in 1876 , when the provinces were abolished, there were about 70 miles of open line to be taken over by the general Government.

The beginnings, then, of state enterprise were closely 


\section{STATE SOCIALISM IN NEW ZEALAND}

connected with governmental ownership of land and the building of roads and railways. The United States, on the other hand, took another line of development. Private capitalists were eager to establish railways in the relatively populous Eastern states, and when it was proposed to build railways in the West there was no serious objection to the chartering of private companies assisted by large grants of public land. A similar development has taken place in Canada, where most of the railways are owned by private companies and where the Government's experience with the Intercolonial Railway does not encourage the trying of further experiments in governmental ownership.

The provinces could not have gone far in the extension of governmental functions without coming into conflict with the general Government, in The Constitu- which rested the supreme power within tion Act the Colony, but the general Government itself was under no such limitations. The Constitution Act of $185^{2}$ ( 15 and 16 Vict., cap. 72) granted such large powers to the General Assembly that New Zealand became to all intents and purposes an independent republic, with power to regulate practically all its internal affairs and even to repeal or amend the Constitution Act itself, with the exception of certain specified provisions. (Constitution Act Amendment, 20 and 2 I Vict., cap. 53.)

In the United States, both state and federal laws are frequently declared unconstitutional because they violate some provision of state or federal

Absence of Constitutional Limitations constitutions, - they involve class legislation, they violate freedom of contract, they interfere with interstate commerce, they take private property without due process of law,- 
in one way or another they are null and void, because of the existence of constitutions in which are intrenched the individualistic principles of the eighteenth century. But the legislators of New Zealand are not troubled by obstacles of this sort. Provided that the Acts of the General Assembly are not "repugnant to the law of England," they are perfectly legal. The New Zealand Parliament, like that of England, can do practically anything it pleases, for the will of the people is not obstructed by constitutional checks and safeguards prescribed by the prejudice and timidity of a previous generation. In this respect New Zealand is far more democratic and less conservative than the United States.

But New Zealand did not go very far in the direction of state socialism before the political revolution of $\mathrm{I} 890$. Before that time the Government was largely controlled by the squatters and other well-to-do people, and the various Early State Activities governmental undertakings were designed chiefly for their benefit and not primarily for the good of the poorer classes. The establishment of the Postal Savings Bank in 1865 is perhaps an exception to this rule; also the creation of Village Settlements for the benefit of immigrants, a charitable undertaking, first begun in Canterbury in 1874 by the Hon. William Rolleston, and afterwards taken up by the general Government in I886. (New Zealand Official Year-Book, 1894, p. 205.)

The first electric telegraphs were begun by the provinces, but the general Government entered the field in I 865 and afterwards took over the provincial lines. This led to the establishment of telephone systems by the Government in I884. At the instance of Vogel, the Government passed a law in 1869 establishing the State Life Insurance Office. In 1872 the Public Trust 
Office Act was passed, also through the influence of Vogel, providing for the creation of a Public Trustee to administer estates. In I870, Parliament passed an Act providing for the establishment of the New Zealand University, and in 1877 the Education Act was passed, providing for the free and compulsory education of children.

In I870, Vogel, then colonial treasurer in the Fox Cabinet, brought forward his celebrated public works and immigration policy, which Parliament Vogel's Public endorsed in an Act providing for the borWorks and Im-
migration Policy within the next ten years, for the construction of railways, telegraph lines, water races for the gold fields, roads, and other public works, and for the encouragement of immigration. In fact, twice the proposed amount was borrowed and spent within the next ten years and a tremendous impetus was given to governmental enterprise, the effects of which have been felt until the present day.

Vogel had great faith in the future of New Zealand and still greater faith in the power of governmental credit. He had established the State State Credit Life Office on the basis of the Government's credit; a little later he was to found the Public Trust Office on the same basis; and now he proposed to borrow enormous sums for the development of the country, although the public debt was already more than the Colony could easily bear. But, as many a business man on the point of bankruptcy has been saved by a timely extension of credit, so the Government borrowed, private citizens borrowed, and the Colony enjoyed for eight or nine years a period of development, inflation and apparent 
prosperity, living on borrowed money. Then, in 1879 , came a terrible depression, from which New Zealand did not fully recover for more than sixteen years.

The policy of Vogel greatly strengthened the power of the general Government, particularly when, in 1876 , he had the provinces abolished, took over their lands and railways, and left the general Government supreme, with

Abolition of the Provinces a large civil service, a great annual expenditure from loans and taxes, and an enormous public debt. The Government had become the dominant financial power in the Colony. Still, with the exception of the work of the State Life Assurance Office and the Public Trust Office, the Government was doing practically nothing more than was being done by New South Wales, Victoria and other Australian colonies, and did not go much ahead of them until the new democracy came into power after the election of 1890 .

The political revolution of 1890 can be traced, with a considerable degree of certainty, to the methods of acquiring and holding land which had obtained since the time of the Wakefield colonies. Edward Gibbon Wakefield,

Theories of

Wakefield the founder of the New Zealand Company, held peculiar views as to the disposal of colonial lands. He thought it desirable to reproduce in New Zealand a fully developed society, with well-to-do people owning land and a sufficient supply of labour to do the developmental work of a new settlement. To that end he thought that land should be sold at a "sufficient price," and that poor but carefully selected labourers should be given free passage to the Colony, where, for a time, they would be willing to work for others, since they could not get free land from the Company. Under this 
system, capitalists would buy land, since they would be assured of a good supply of labour for the development of it. The money received from the sale of lands was to be spent on roads and other public works and on bringing out a further supply of labour. (Reeves, "State Experiments," vol. I, pp. 200-218; Scholefield, " New Zealand in Evolution," pp. I72-176.)

Perhaps, if Wakefield's whole scheme had been put into operation, and if there had been a sufficient supply of land, and if a few wealthy people had

Landless

Labourers not been allowed to acquire large blocks by purchase and lease, and if the Colony had been an agricultural rather than a pastoral country, the assisted labourers might have acquired land quickly instead of remaining labourers for years, congregating in the towns, especially during the winter months, discussing their grievances and clamoring for political reform. But the land was not only sold but leased in enormous tracts, and the new-comers, finding it more and more difficult to get land, were much dissatisfied and looked to the Government to redress their grievances.

The immigration and public works policy of Vogel, while it provided employment at high wages for a time, in the end increased the trouble, for the prices of land improved by the roads and railways increased so much as to be quite out of the reach of poor men, while people who had a little capital were tempted to buy too much land, chiefly with borrowed money, and had to give it up to the mortgagee when the time of inflation came to an end. Then the assisted immigrants, many of whom had been employed in building roads and railways, were thrown out of work, and either left the country or remained to curse the landowners and importune the Government. 
The statistics of immigration and emigration during these years throw much light upon the situation. In the year $1874,43,965$ persons arrived in the Colony, including 36,400 from the United Kingdom, of whom 3I,774 were assisted immigrants; in the year I88I there were only 9,688 arrivals, of whom only 103 were assisted; while from 1885 to 1891 there was an excess of emigrants over immigrants amounting to 19,938 (Year-Book, I894, pp. 7I-76).

If the whole of Vogel's policy had been accepted by Parliament, the amount borrowed for public works would have been less, and more land would have been available for settlement, for he proposed to defray a large part Foresight of Vogel of the cost of the railways by the sale or lease of six million acres of public land, much of which could have been taken up by relatively poor men. But the landowners defeated this part of his scheme while accepting the part involving enormous borrowing for railways and other public works which should add to the value of their lands without providing permanent occupations for the surplus population.

The long years of depression which followed the bursting of the boom were the worst that New Zealand has ever seen. Mr. Scholefield says:

"All the glory of the seventies had passed away. New Zealand was in a state

Years of

Depression of the utmost depression. Legislation was quite powerless to remedy evils which were economic and not merely political. Many colonies have had similar crises to face; but in New Zealand a position which would naturally have arisen at a certain stage of the Colony's development had been aggravated incalculably by the reckless and extravagant importation of certain classes of immigrants to whom the necessary avenues of occupation were closed. Thousands of disappointed men, efficient, industrious, and temperate, left the colony in despair. Of those who remained many had emigrated from the Old World a few years earlier, full of hope and enthusiasm. They were now inconsolable agitators. A revolution was at hand." (Scholefield, "New Zealand in Evolution," p. I69.) 
And yet it was during the dreary depression of the eighties that an invention was made which revolutionized the sheep-raising industry and laid the Frozen foundations for the extraordinary prosMutton perity of later years. This was the improvement of the process of refrigeration, at first applied to the freezing of meat, but later used in the shipping of dairy produce and fruit. The first attempts to export frozen mutton were made by Australian shippers, but the first really successful shipment was made from Port Chalmers in 1882 under the direction of Mr. Thomas Brydone, the general manager of the New Zealand and Australian Land Company, one of the largest holders of land in New Zealand. In this case, if in no other, the large landholders rendered a service to their country. Of this epoch-making event Mr. Scholefield says:

"The meat was landed in perfect condition and sold for $6 \mathrm{I}-2 d$. per pound - a price which has not since been reached. The "prodigious fact' was there, to quote The Times, that fresh meat from the antipodes had been landed in London in perfectly sound and wholesome condition. And prodigious it was for the colonial meat industry. For New Zealand it utterly revolutionized both agriculture and grazing." (Scholefield, op. cit., p. I29; Year-Book, I893, pp. I90-198.)

The importance of this new industry can hardly be over-estimated. Before $\mathrm{I} 882$ it was impossible to ship mutton to the European markets beAn Industrial cause of the long voyage across the Revolution tropics, and there was no market for mutton in the Southern hemisphere beyond the slight demand for local needs.

"At this stage the whole marketable product of a sheep was a few fleeces of wool, a pelt, and a boiled-down carcase. Except in the close environs of a town, cattle were useless except for the skin and the horns. Possibly some preserved meat brought in a little income, but more of ten the carcase was returned to the land from the animal fertiliser works." (Scholefield, op. cit., p. I2I.) 
Thousands of sheep were sold for sixpence a head, and many more were merely destroyed by the farmers when it no longer paid to keep them on pasture. Similarly, butter and cheese were made chiefly for the local markets, but with the advent of the refrigerator the dairy industry rapidly increased in importance until it took third place in the list of exports.

But it must not be thought that frozen mutton immediately took possession of the British markets. There was and still is a prejudice against frozen meat of any kind, although connoisseurs have declared that New Zealand frozen mutton is equal to the best home-grown mutton. The shipment of $\mathbf{1} 882$ was valued at $£$ r 9,339 $(\$ 95,000)$, and it was not until the year I 890 that the value of the exports of frozen meat exceeded £1,000,000 $(\$ 5,000,000)$, and the exports of butter and cheese did not exceed $£$ I,000,000 until the year rgor.

The following figures show the values of the exports of wool, frozen meat and dairy produce for the years I882, I892 and I907: (Year-Book, I909, p. 639).

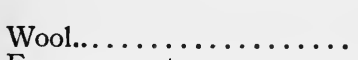

Frozen meat............

Butter and cheese........

Total exports.............. exclusive of Maoris...

\begin{tabular}{|c|c|c|}
\hline I 88 & I 892 & 1907 \\
\hline$£_{3, \text { I I } 8}$ & $£_{4,3} \times 3,307$ & $£_{7,657,278}$ \\
\hline & $\mathrm{I}, \mathrm{O}_{3}$ & 3,4 \\
\hline $\begin{array}{r}62,2 \\
6,253,3\end{array}$ & $3 I$ & 2,2 \\
\hline$£ 6,253,350$ & $£ 9,365,868$ & $£_{19,783, \mathrm{I}}$ \\
\hline & & \\
\hline
\end{tabular}

It is hard to say what New Zealand would have been without refrigeration. Certainly, the production of wool could not have increased as it has, no amount of legislation could have made small farming profitable, and in all probability most of the labour legislation would never have been enacted. Without doubt, refrigeration has done more for the small farmer and the workingman than all the legislation of the past twenty years put together. 
The only serious misgivings as to the continuance of this prosperity arise from the fact that New Zealand has no monopoly of refrigeration. AusPossibility of tralia uses the same process; also ArgenOver-production tina; and, since England is practically the only open market, it is possible that there may be an over-production of wool and mutton, prices may fall, and another period of hard times may be in store for New Zealand and other countries whose prosperity depends chiefly upon the export of a few staple products. The glut in the British market for frozen mutton in the year 1909, when the wholesale price in London dropped to 2 I I-I 6 d (5 3-8c) a pound, was severely felt in New Zealand, and would have had the most serious consequences if it had continued very long and if the prices of wool had not been well maintained. But wool, mutton and dairy produce are necessaries of life and not articles of luxury; the world's population is increasing; it seems likely that new markets will be opened, and that there will be a steady, if not increasing demand for all that New Zealand, Australia and South America can produce.

The full effects of refrigeration were not felt until well on in the nineties. Meanwhile, hard times continued, and resulted in the victory of the Liberal Political Revo- Party in the election of December 5, lution of 1890 I 890 . The land question was the chief issue, and Ballance and his friends rallied to the Liberal standard all those who wanted land and all who sympathized with them and were opposed to the monopolistic spirit of the great landholders.

This prejudice against large landholders has hardly existed in the United States and Canada, where land 
has been used more for agricultural than pastoral purposes, where small holdings have been the rule, and where large owners have usually been willing to divide their estates and sell at Small Holdings a profit to small farmers. New Zealand, in America on the other hand, is still predominantly

- a pastoral country; large estates are frequently more profitable per acre than small holdings; and wealthy people, who appear to have the English idea of acquiring a great estate and founding a country family, often refuse to part with their land at any price when the interests of the people as a whole demand closer settlement. In 1890 , there was an extraordinary concentration in the holding of land and even at the present time a large part of the land is held by a very few people. Writing of the condition of affairs when the Liberal Government came into power, Mr. Reeves says:

"Not half the 66 million acres of land which the islands contain were then settled upon even in the sparsest way. Yet 585 persons or companies owned between Io and I I million acres; 684 companies or persons owned or occupied real estate the unimproved value of which was only a little less than $£ 22,000,000$. Two-thirds of I per cent. of the landowners held 40 per cent. of the land values. Putting urban land on one side, a return of rural holdings of more than five acres in extent showed that one eightieth of the country landholders held two-fifths (in value) of the land. The price of land had fallen in I89I; some of the large owners were by no means prosperous; but pity for them did not get rid of the necessity for challenging monopoly, settling the soil, and peopling the country." " "Land Taxes and Rates and Valuation of Land in New Zealand," a memorandum prepared for the Chancellor of the Exchequer, 1909; YearBook, 1892, p. 94.)

The agitation against the large landholders was one of the two chief factors which brought about the victory of the Liberal Party; the other was the growing power of organized labour. Labour in The labourers of the towns fully agreed Politics with their comrades of the country as to the desirability of breaking up the great estates and 


\section{I4 STATE SOCIALISM IN NEW ZEALAND}

opening the land to closer settlement; but they had also grievances of their own. Wages had fallen since I879; there was much unemployment, particularly during the winter months; and in the larger towns conditions of employment had arisen very similar to the sweating system of the Old Country. The Sweating Commission, reporting in May, I890, disagreed as to the existence of sweating, but it was generally admitted that labour conditions were bad, especially in regard to the employment of women and children for long hours, at low wages, and in overcrowded, unsanitary workshops. Mr. Scholefield says:

"The evils which existed at that time were, of course, primarily due to the terrible depression under which the Colony had laboured for the last ten years. But their intensity was plainly the result of the absolute lack of any regulation." (Scholefield, op. cit., p. 197.)

The Knights of Labour and other organizations were quite active during the later eighties, and then, in 1890 , came the Maritime Strike, which united The Maritime the workingmen and prepared them for Strike the political struggle of the same year. Another thing which increased the political power of the workingmen was an Act passed in I 889 prohibiting electors from voting in more than one electoral district at any election for the House of Representatives. Previous to this, people owning property in several districts were allowed several votes, and this gave a great advantage to the propertied classes. The election of 1890 was the first election of members of the House on the one-man-one-vote principle.

The labourers were unsuccessful in the strike, which came to an end early in November, but on December 5 the Liberal Party, with the aid of the Unions, were victorious at the polls. It is interesting to note that organized labour in Australia, after being defeated in the 
Newcastle strike of 1909-I0, when several of their leaders were condemned to prison, won a still greater victory in the elections of April, I9I0, and Mr. Andrew Fisher, once a poor miner, became Prime Minister of the Commonwealth. Thus the Australian Labour Party, remaining independent, accomplished in a more thoroughgoing manner what the New Zealand labourers accomplished in 1890 through an alliance with the Liberal Party.

The Hon. John Ballance, who became Premier on January 24, I89I, was primarily a land reformer, as was also the Hon. John McKenzie, the Minister of Lands in the new Cabinet, but the Hon. William Pember Reeves, the

Labour

Legislation

Minister of Labour, had at heart the

welfare of the working class, and was the author of most of the labour legislation of the next five years. Among these Acts the most important were the following: The Employers' Liability Act Amendment Act, I89I; The Truck Act, I89I; The Factories Act, I89I; The Coal Mines Act, I89I ; The Contractors' and Workmen's Lien Act, I 892; The Shops and Shop-assistants Act, 1892; The Workmen's Wages Act, I 893; The Shipping and Seamen's Act Amendment Act, I 894; the Industrial Conciliation and Arbitration Act, I894; and The Servants' Registry Office Act, I 895. Most of these Acts have been amended many times, and constitute a formidable body of laws designed for the protection of workers in almost every field of industry. ("The Labour Laws of New Zealand," fourth edition, 1905.)

Since Mr. Reeves left the Colony in 1896 to become Agent-General of New Zealand in London, the only distinctive Acts that have been passed for the benefit of labour are The Old Age Pensions Act, I898; The Midwives Act, 1904; The Workers' Dwellings Act, 1905; and The Government Advances to Workers Act, 1906. 


\section{I6 STATE SOCIALISM IN NEW ZEALAND}

It might be thought that labour got more than its share of the benefits of the Liberal administration, if one did not consider the important series Land Reform of Acts designed to break up the great estates, to make it easy for poor farmers to purchase land, to relieve them of the burden of taxation, and to lend them money at low rates of interest. Of these Acts the chief were: The Land and Income Assessment Act, I891; The Dairy Industry Act, 1892; The Land Act, I 892; The Land for Settlements Acts, 1892; The Government Advances to Settlers Act, 1894; and the Government Valuation of Land Act, I896. These Acts have been amended from time to time, and some of the later amendments, like The Land Laws Amendment Act, 1907, have not been quite so favourable to the farmers as the earlier Acts.

Apart from Acts like these, which were frankly designed for the benefit of the labourers, on the one hand, and the small farmers, on the other, State Trading there was not much extension of governmental functions before the year I90I. In that year The State Coal Mines Act was passed, and the State began to mine and sell coal in competition with private companies. The Accident Branch of the Government Insurance Department was opened in I90I, and two years later the State Fire Insurance Office was opened. Besides these, a number of minor State enterprises have been undertaken from time to time, such as the purchase of the patent rights of the cyanide process, which the State leases to miners at a reasonable royalty; the placing of the Auckland oyster beds under Government management; the establishment of fish hatcheries; the stocking of the rivers with trout; and the establishment resorts for tourists and invalids at Rotorua, Te Aroa and Hanmer. 
Not only does the State do all these things, and more, but it is constantly being importuned to assume new functions, to invade new fields of private enterprise. Mr. Scholefield says:

"Scarcely a month passes without some convention passing a cheerful resolution demanding that the Government should step in and operate some new industry for the benefit of the public. Now it is banking: to-morrow bakeries: over and over again some moderate reformers have called upon the Government to become the controllers of the liquor traffic: once upon a time it was importuned to become a wholesale tobacco-seller: more than once to purchase steamers to fight the supposed monopoly of existing lines." (Scholefield, "New Zealand in Evolution," p. 258.)

But, notwithstanding these demands, the feeling seems to be growing that the Government should not move too rapidly in the direction of state socialism. The laissez-faire theory has never had much influence in New

Opportunist Zealand, nor has any socialistic doctrine had much to do with the increase of governmental functions. The people of New Zealand are not doctrinaires, and the academic question as to the proper spheres of governmental and individual activity is seldom discussed. The State has taken up one thing after another as the result of concrete discussion of concrete cases. Usually, if not invariably, abuses have been thought to exist, which the State has been called upon to remedy: the great landowners have stood in the way of closer settlement: wages have been low and conditions of labour bad: rates of interest, insurance premiums, prices of coal, and rents of dwellings have been thought to be high: the oyster beds have been depleted by private exploitation: taxation has fallen too heavily upon the poor: for one cause or another there has been complaint, complaint has grown into agitation, and agitation into legislation. 
If there is any prevalent theory as to the scope of governmental activity, it is a form of paternalism, which regards the State as the parent or

Paternalism guardian of the people, particularly of the poor and weak, for the sake of securing the greatest good to the greatest number. The Hon. Dr. Findlay, who is both scholar and statesman, recently said:

"Thought and experience have shown that in modern nations the system of natural liberty is not a policy of true progress; that, on the contrary, such progress can be attained only by limiting greatly individual liberty and by eliminating the struggle for a bare existence by checking and removing the competition and other conditions which give rise to it. This involves provision both for the ascent of capacity and the descent of incapacity. The true policy of progress in modern nations is not the mere protection by the State of legal rights, but provision by the State of the conditions which are essential to the welfare of the people. This means the securing for all who need it some measure of freedom of opportunity as well as protection." (Lecture by Dr. Findlay before the Philosophical Society at Palmerston North, April 21, I910.)

And yet, all careful observers recognize the fact that much of the legislation of recent years is still experi-

Need for Criticism of Socialistic Legislation mental in its character, and that it has yet to stand the test of a prolonged industrial depression. Not only must the workings of past legislation be critically examined, but every new proposal to increase the functions of the State must be subjected to a searching criticism, and it must be clearly shown in every case that the benefits to be secured are sufficient to outweigh the evils necessarily connected with a curtailment of individual liberty. Dr. Findlay may be regarded as expressing the general attitude of the Ward Government when he says:

"While the functions of the State must increase in area and number if our social ideals are to be promoted, every increase should be jealously watched. Excess of social control upon the individual life is as pernicious as excessive liberty." (The Evening Post, April 22, I910.) 
While the social legislation of the past twenty years is not socialistic in the sense of being inspired by socialistic doctrine, it is socialistic in that it has been brought about by a political uprising of the middle and lower classes against the rich. The liberty of landowners and other capitalists has been restricted in many ways; the Government has made efforts to equalize the distribution of wealth; the strong have been compelled to bear the burdens of the weak; and some, at least, of the property of the rich has been taken away and given to the poor. The political evolution has been along the line of socialistic prophecy, anticipated in ancient times by Aristotle, who said: "If the poor, because they are in the majority, may divide among themselves what belongs to the rich, is not this unjust? In sooth, by heaven, it will have been judged just enough by the multitude when they gain the supreme power." ("The Politics," Book III. chap. VI.) 


\section{CHAPTER II}

\section{LAND TENURE}

IT might be supposed that in a country like New Zealand, so recently settled and so democratic in its

Predominance of the Land Question constitution, the evils of the land problem in older countries would have been successfully avoided. Yet the people of New Zealand have been troubled about this question since the arrival of the earliest settlers, and there has scarcely been a year since responsible government was granted in which Parliament has not passed new land laws or amended old ones. The Land Act, I 892, repealed fifty-two Acts and Ordinances, and since then sixty-eight amendments of more or less importance have been passed.

Two main aspects of the land question have from time to time loomed large in the public mind. The first of these is, "Should the State sell its lands or merely lease them?" The second is, "What is the most effective means of preventing land monopoly, of breaking up the large estates?" At various times one or other of these questions has engrossed the attention of Parliament and the people. The attempts made and the results achieved form one of the most interesting object lessons New Zealand has yet furnished to the student of economics.

The advisability of the State's retaining its own lands did not enter seriously into politics until the decade between 1870 and I880. Prior to Early Selling that the legislature and the provincial of Land governments were more concerned with getting the land taken up and settled 
than with any theoretical views of land tenure. Edward Gibbon Wakefield, the founder of New Zealand, laid down the principle that the land should be sold at a uniform and sufficient price and the proceeds employed in importing labour and carrying out public works. His system has been fiercely attacked as an attempt to reproduce a landed aristocracy in New Zealand, and has been ably defended as a means of securing settlers of a good class, checking monopoly, and preserving the public estate. (Reeves, "State Experiments," Vol. I.)

The details of the early disposal of the public lands are extremely involved, owing to the system of local government which prevailed. There were six provincial councils - and later eight - all developing their settlements in their own way. But they all sold their lands for cash, or on deferred payments, at prices varying from $5 s$. to $£ 2$ an acre, with the double object in view of settling the land and securing an immediate revenue for roads and other public works. When the provinces were abolished, in 1876 , the Crown lands were taken over by the general Government.

In 1870 the Colony entered on a large system of borrowing for public works and immigration. Two results followed: first, the large loans rendered it unnecessary for the State Results of Public to rely on land sales as a means of getting Works Policy funds to build railways, roads and

bridges; secondly, the construction of these public works and the inflow of immigrants rapidly enhanced land values. The freeholders were well satisfied with this result, but a few thoughtful men began to question the expediency of first parting with the public estate and then enhancing its value in the hands of private persons by spending millions in public works. 
The names of three statesmen are closely associated with the efforts made to retain the public lands, or part of them, for the State, a policy advoThe Perpetual cated by Sir Robert Stout in the House Lease of Representatives as far back as $\mathbf{I} 875$. Rolleston, who became Minister for Lands in 1879 , was a man of fine culture, liberal views, and rare political honesty. In 1882 he introduced a land bill by which he proposed to institute a system of perpetual leases as regarded one third of the Crown lands. The rents were to be 5 per cent. on the unimproved value of the land, with revaluation after thirty years and later revaluations after periods of twenty-one years, and were to be applied for educational and other purposes. In a speech which is still one of the best that can be read on the land question, Rolleston pointed to the dangers of land monopoly and the advantages which were to be derived from large landed endowments. (Reeves, "State Experiments," Vol. I, p. 242.)

Had Rolleston succeeded in his plans the whole history of the land question would have been changed. But the Upper House, which was then a very conservative body, representing chiefly the landholding interests, was strongly in favour of the freehold and insisted] on inserting a clause giving the lessees the right of purchase at the prairie value, which was about $£_{I}$ an acre, as soon as they had fenced the land and cultivated one-fifth of it. To this Rolleston strongly objected, because, as he pointed out, the perpetual lease would then be merely a duplication, with slight changes, of the deferred-payment system which had been in force six years. He tried repeatedly to cut out the right of purchase, but his efforts were fruitless. The Upper House remained ob- 
durate and defeated his object both in the bill mentioned and in a similar bill introduced the next year.

The perpetual lease immediately became very popular. Up to December 3I, I892, I,I 88,07 I acres were taken up under this system. It had the effect of lessening the demand for Advantages of land on deferred payment, since the this System rental was only 5 per cent. on the value of the land, and the lessees had all the security and permanence of freehold tenure, without requiring to sink any capital in the purchase of the land until they found it convenient to do so. Also, there was a temptation to postpone the right to purchase, since money was worth to the farmer a good deal more than the 5 per cent. rental which he was paying to the Government. But gradually the perpetual leases were converted into freeholds, and on March 3I, I909, only 86,908 acres were held under that tenure. Doubtless, most, if not all of these holdings will be converted into freeholds before the expiration of the 30-year period. The perpetual lease was superseded by the methods introduced by the Land Act of 1892. (Official Handbook, I 892, pp. 92, 283. Official Year-Book, I893, pp. II 8, 364. Year-Book, I894, pp. I48, 209. Year-Book, r909, p. 5I6.)

The next Minister for Lands was Ballance, who was even more strongly in favour of land nationalization than was Rolleston. In I885 he repeated the attempt made by Rolleston and No Revaluation sought to lay down the principle that the State should retain one-third of its lands for all time, to be leased on condition of periodical revaluation. A long struggle again ensued, but a similar fate befell his bill, and the right of purchase was again inserted.

The third Minister for Lands who tried to establish 


\section{STATE SOCIALISM IN NEW ZEALAND}

the principle of State ownership was McKenzie, Minister for Lands and Immigration and AgriThe Lease in culture in the Ballance Cabinet. McPerpetuity

Kenzie was a Highlander of strong personality, deeply impressed with the evils of land monopoly in Scotland and determined at all costs to prevent such a system in New Zealand. He felt that once the freehold was granted, there was nothing to prevent the rich man from buying out the small settler. He believed that the only way to prevent the aggregation of large estates was for the State to retain the land and lease it. But he was a practical farmer, and when the objection was raised that the farmer would not cultivate the land as well under the system of leasing as under the freehold system, he decided to give the tenant a term which was as good as the freehold, but to retain the nominal ownership in the hands of the State to prevent the building up of large estates. He therefore granted leases for 999 years at a fixed rental without any periodical appraisement, but also without the right of purchase. The rental was calculated at 4 per cent. on the capital value of the land at the time the lease was taken up. Certain conditions were imposed upon the lessee in regard to residence and improvements, and it was provided that no lessee should hold more than one lease in perpetuity except under certain special circumstances. (The Land Act, r892.)

The bill was bitterly opposed by Rolleston. He said:

"The lease in perpetuity that the Government has accepted

Evils of the

New Lease is practically a freehold, and there is no man who doubts for a moment that the residential tenure of the Act will very shortly be done away with. It will not require more than two or three years before the people will rise against the persecutions, limitations, and vexatious annoyances such as appear under this bill. There is no unearned increment to come in, no provision for revenue in aid of local government, no aid to taxation in the future. 
This bill as it must be carried out will destroy the land revenue. It fosters evasion, gambling and speculation." (Parliamentary Debates, Vol. 78, p. 61, Sept. 13, 1892.)

Mr. Fish was even more bitter in his denunciation of the bill. He said:

"This unearned increment will go simply into the pockets of those who choose to speculate in this new system of freehold landtenure; because I maintain that it is practically a system of freehold land-tenure with this small and trifling difference; that in the case of an ordinary freehold tenure the purchaser has to deposit cash with the Crown, but the fortunate recipient of one of these leases in perpetuity obtains the freehold of his land - because if a 999 years' lease is not a freehold in fact, then I know not the meaning of the words - without the small consideration of paying any cash down for it. . . Instead of having roads, and bridges and railways made out of the proceeds of our land sales, or out of the unearned increment, we shall have to make our roads and bridges out of fresh taxation on the people, which will press on two thirds of the population, who will not settle on the land. . . I have no hesitation in saying that it would be the best policy this House could pursue to sell every acre of the land it has, or may have in the future, as speedily as possible, and merely restrict the area to be held by one man, and by legislative taxation compel cultivation of the land suitably by those who hold it in large areas." (Parliamentary Debates, Vol. 78, pp. 63-69.)

This amazing tenure, the "lease in perpetuity," popularly known as " the eternal lease," has during recent years formed the storm centre of New Zealand politics. Despite the criticism The Eternal to which it was subjected in Parliament Lease and elsewhere, its author does not seem to have realized what its results would be. It meant that for ten centuries the State parted with all its interest in the land save 4 per cent. rental on the original value. It meant that in the course of a century or less, the State would probably be losing more by way of land tax than it got by way of rent; that no matter what increase in land values took place, owing to the construction of roads and railways, the State could claim nothing more than the ordinary and graduated land-tax on the lessee's interest.

No one can be said to have begun to understand the 


\section{STATE SOCIALISM IN NEW ZEALAND}

elementary principles of land tenure in New Zealand who cannot distinguish between the "perpetual lease" of Rolleston and Ballance and the "lease in perpetuity " of McKenzie. By the Act of 1892 the granting of Crown lands under the system of perpetual lease was abolished, and the lease in perpetuity took its place. Crown lands could still be bought for cash, or the settler could obtain a license for occupation with right of purchase within twenty-five years, but the lease in perpetuity soon became the most popular system. Although the area which could be held by one man was limited to 640 acres of first-class land or 2,000 acres of second-class land, the advantages to the tenant, especially to the poor settler, were obvious. He had, for all practical purposes, a freehold without having to buy the land. However, the lease in perpetuity was inferior to the perpetual lease, from the point of view of the lessee, in that there was no right of purchase.

In the year ending March 31, I894, 34,327 acres of Crown lands were bought for cash, 108, I33 acres were taken under the system of occupation with right of purchase, and 179,993 acres were taken under the lease in perpetuity. Up to March 3I, I909, about 2,4I8,000 acres had been taken under the lease in perpetuity by 5,174 tenants. (Year-Book, 1902, p. 443. Year-Book, I909, p. 5I6.)

The Colony, soon after this system of land tenure was begun, entered on an era of unexampled prosperity. The

The Crown Tenants ask for a marked degree. The tenants, who the Freehold soon numbered some thousands, waxed prosperous, and after about ten years they began to ask for the right to buy the freehold of their properties. The chief reasons urged for this course were: 
(I) That it would pay the Colony to sell the freehold and expend the money received in purchasing large estates for subdivision and closer settlement, instead of borrowing millions abroad for this purpose and remitting the greater part of the rents to the foreign money-lender by way of interest.

(2) That the restrictions as to cropping, personal residence on the property, and other covenants in their leases were vexatious, and that by purchasing the freehold they could farm their lands as they wished.

(3) That the labour unions and single-tax advocates were agitating for reappraisement of lands and readjustment of rents, although the lands had been leased at a fixed rental for 999 years.

As to the last mentioned reason, while it has been denied that such agitation took place, without doubt the labour party freely advocated this course. Some of their leaders disavowed the proposal as involving a grave breach of contract on the part of the State, but

Revaluation demanded by Labour Unions the revaluation of rents was constantly proposed at their annual conferences. For example, at the annual conference of the Trades and Labour Councils of New Zealand, held at Christchurch in April, 1906, Mr. Hampton moved: "That the Conference approve of the abolition of sale of Crown lands, and provision for the periodical valuation of all Crown lands held on lease, at the death of the present lessee, or the transfer of the lease to another party, whichever shall occur first." $\mathrm{Mr}$. Paul moved an amendment providing simply for revaluation in future leases, saying that " the proposal to interfere with existing contracts was immoral and unjust." The amendment was lost. Mr. Breen then moved as an amendment that revaluation take place at the expiration of 50 years from the date of issue of the lease. This 
amendment was carried, by 9 votes to 7 , and the original motion, as amended, was carried. (Report of Annual Conference of Trades and Labour Council, I906, p. I6. Report of 1907, p. 12.)

The question soon became a political one. This in itself is significant, and had been predicted as far back as I 882 by the opponents of Rolleston's scheme. These opponents argued against the creation of a State tenantry on the ground that so soon as the tenants became numerous enough to exercise political pressure, they would demand the freehold, or, in times of depression, would demand a reduction in rent. By 1905 the pressure had become so great that even Seddon could not fend off the issue any longer. To gain time he appointed a Royal Commission to report on the whole subject of land tenure. The Commission were divided in their recommendations, half advocating the granting of the freehold on certain conditions and half the contrary.

After many debates the legislature, in 1907, allowed the right of purchase to the lessees in perpetuity. In the words of the Act:

Restricted Right " Every owner of a lease in perpetuity shall of Purchase have a right at any time during the existence of the lease to purchase the fee-simple of the land comprised in the lease at a price equal to the capital value of the said land at the time of the purchase thereof. The said capital value shall be determined by valuation or arbitration in the manner hereinafter in this section provided, and shall include the value of all minerals other than gold and silver, but shall not include the value of any improvements placed on the land during the continuance of the lease." (Land Laws Amendment Act, 1907, Sec. I8.)

This concession has been declared valueless by the tenants, who would regard it as a grim joke on the part of the legislature if they did not think

At What Valuation? it a step toward further concessions at a later date. The whole question at stake was: "What was to be treated as the value of the land - the original value at the time the 
tenant took his lease, or the value at the time of purchasing the freehold?" The question was important, because the rent payable to the Government was in most cases less than the annual value of the land, and many tenants had bought their leases and paid thousands of pounds for them. If they had to pay over again to the State for the right to become freeholders at the present value of the land, they would be paying twice over for the same thing. The State had granted leases for 999 years at a fixed rental, without revaluation, hence its only interest in the land was the capitalized rental of 4 per cent. on the original value.

On the part of the State it was argued that the tenant, in getting the freehold, was getting something which he had not bargained for and that it would be monstrous to allow him to purchase, at the original value, lands which had doubled and trebled in value since they were taken up. If the tenant had wanted the freehold, why had he not bought it at the beginning? And yet, the State would gain by selling the freehold at the original value, for it would be relieved of the trouble and expense of administering the public estate, would be getting 4 per cent. money in New Zealand instead of borrowing it abroad, and would get additional revenue in the form of land tax on all the larger estates. It is surprising to find single-taxers, like Mr. Fowlds, Mr. Ell, and Mr. Laurenson, opposing the freehold. Logically, they should be freeholders, for the simplest way of getting the " unearned increment," as Henry George has shown, is to let private persons hold the land and to take all the rent away from them by a tax on the unimproved value. But the concession of 1907 was welcomed by the freeholders as a step in the right direction. Mr. Mander said, speaking of the freehold: 
"We have got a shadow of it, but we shall have the substance later on; we are quite satisfied about that point." (Parliamentary Debates, Vol. I4I, p. 68I, Oct. 21, I907.)

The lease in perpetuity was abolished by the Act of 1907. This course met with universal approval and partially corrected one of the worst The Renewable blunders ever made in land legislation. Lease

The new law, however, could only apply to the future, and under the lease in perpetuity system, which had been in force for fifteen years, over two million acres of the best land of the Colony had been parted with. In its place was enacted the " renewable lease," a lease for 66 years, with provision for valuation and renewal at the end of the term at a reappraised rent. (Land Laws Amendment, 1907.)

The Act of 1907 did not abolish the other forms of tenure, for public lands may still be sold for cash or on the occupation-with-right-of - purchase Other Forms system. The leasing system has always of Tenure

been only one of three methods of disposing of Crown lands. From I 882 to I892, lands might be sold for cash or on the deferredpayment system, or on perpetual lease with right of purchase. From 1892 to 1907 , the two former systems continued, while the lease in perpetuity was substituted for the perpetual lease. In 1907, the renewable lease took the place of the lease in perpetuity, the other systems remaining as before. It is commonly believed in America and elsewhere that all the land in New Zealand is owned by the State. How far this opinion is from the truth is shown by the fact that on March 3I, I906, there was held as freehold more than $18,500,000$ acres of rural land. (Year-Book, I909, p. 447.) At this time the total area of $66,861,440$ acres was held roughly as follows: 
Freehold

$18,500,000$

Leased from Crown............................... 17,000,000

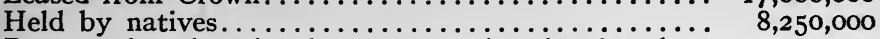

Reserves for educational purposes and national parks.. $12,250,000$

Unfit for use............................... $\quad{ }_{7,000,000}$

Not yet dealt with............................. $3,300,000$

In 1906 the Government proposed that no more Crown lands should be sold, but this proposal met with such strong opposition that it had to be modified. Accordingly, in 1907, "The National Endowment Act" was passed,

National

Endowments setting apart 7,000,000 acres of Crown land as a permanent endowment for educational purposes and to assist in paying old-age pensions, and provision was made for ultimately increasing the area to 9,000,000 acres. The Act expressly provides that these lands shall not be sold for cash, nor disposed of under the occupation-with-right-of-purchase tenure. (Year-Book, I909, p. 664.) But even this measure would not have been accepted had not the avowed object been to create endowments for specific purposes, and had not other legislation in the same year made it probable that by increased taxation of large estates, and by the acquisition by the State of native lands for settlement, large areas of freehold would be thrown upon the market.

A further concession to the freeholders was proposed by the Government in the session of 1909, when a bill was brought down providing that the lessees of land held on the lease in perpetuity or the renewable lease might acquire the freehold by purchase at the original value, but with the provision that the land should be revalued at intervals of 33 years and that at these times 20 per cent. of the increment during the preceding 33 years should be payable to the Crown. After five such intervals, the holders of leases in perpetuity were to acquire the fee-simple, but the holders of renewable 
leases were to have their land revalued at perpetually recurring intervals. In this respect the bill was similar to the proposals of Lloyd-George in the celebrated Budget of I909. The bill was another attempt to effect a a compromise between freeholders and leaseholders, but was not satisfactory to either party, and was dropped. (Evening Post, Wellington, Nov. 24, 1909. The Press, Christchurch, Nov. 25, 1909.)

It may be that the new system of renewable lease will prove profitable to the State and satisfactory to the tenant - time alone will show. But the State Tenants chief danger of a large state tenantry in Politics has already been strikingly illustrated, namely, the immense political pressure which they can exercise. There were, on March 3I, I909, 25,204 Crown tenants, holding I8,264,083 acres, and there can be no question that they will agitate for the freehold so long as there is the slightest chance of getting it, and in their demands they will be supported by about 45,000 freeholders of country lands, most of whom are strong upholders of the tenure which they enjoy. (YearBook, 1909, pp. 447, 517.) Even if they do not succeed in obtaining the freehold, they are quite likely to clamor for reduction in rents in times of depression, as, indeed, they have already done. One witness before the Land Commission of 1905, on being pressed to give reasons or his belief in the freehold, said:

"I believe in the freehold because the freeholder is the man to whom, in times of trouble, the State will look; and the leaseholder is the man who, in times of trouble, will look to the State."

No doubt, as the industrial population grows larger, and the agricultural and pastoral interests become less dominant in political life, further attempts will be made to extend the principle of state ownership. But hitherto 
the farmer has proved too strong for the land reformer; and, if he has not succeeded altogether in getting his own way, he has at least prevented the theory of state ownership from being carried to its legitimate conclusion. But the advantages of state ownership have been much exaggerated and it is not easy to show that New Zealand has derived any benefit that could not have been obtained from freehold tenure combined with taxation of land values. It is probable that had the efforts of the legislature in the past been concentrated upon the prevention of land monopoly and closer settlement on freehold farms, more progress would have been made than has been possible on the lines attempted in the past. 


\section{CHAPTER III}

\section{LAND MONOPOLY}

The climatic conditions of New Zealand, as compared with those of America, go far to explain why land Comparative monopoly has been more common in the Size of Holdings former country than in the latter. In in New Zealand the northern parts of The United States, and America and in Canada, the severe winters make it difficult for a man to hold more than a very limited area of land. The season during which he can sow and reap is short, and during the winter he must house and feed his stock. Again, in the arid region only so much land can be used as the farmer can effectively irrigate. In New Zealand, on the contrary, the climate is so mild that, except in the high country, the farmer can work his ground in midwinter, while sheep and cattle can remain on the open pasture all the time. Indeed, the only limit to the extent of country a farmer can stock is the limit of his purse. Because of the mild climate, and because of the remoteness of New Zealand from the markets of the world, the country was more suited to sheep raising than to agriculture, and sheep raising is an industry that, in such a climate, is most profitable when carried on on a large scale. The United States and Canada are in most parts better suited to agriculture than to the raising of cattle or sheep, and mixed farming is usually more profitable than the growing of staple crops, so that there has been a strong tendency toward a system of farming on a small scale, and this tendency has been greatly encouraged by the homestead laws. But 


\section{LAND MONOPOLY}

legislation has had little to do with the agricultural development of the United States and Canada, whereas the development of agriculture was so slow in New Zealand that the small farmers and the landless people thought it necessary to pass laws for the purpose of hastening economic development, so that the country might not long remain a vast, thinly populated sheep-run, but might soon become a closely settled agricultural community.

These facts explain to a large extent why the holding of large tracts of land has been such a burning question almost from the time of the first settlement. A class struggle has been going on between the large run-holders, on the one hand, and the small sheep raisers and agriculturists, on the other, a struggle in which the large holders for a long time had the upper hand, though the small farmers were in the end victorious, by means of the ballot and the political revolution of $\mathrm{I} 890$.

In the North Island so large an area was covered with forest, and conflicts with the natives were so frequent, that the progress of pastoral pursuits was

retarded. But in the South Island the Origin of wide fertile plains of Canterbury offered Large Holdings a tempting field for pastoral life. On these plains occurred the most classic examples of land grabbing that New Zealand has seen. And yet, the early land regulations seem to have been expressly designed to prevent the creation of large estates. The public lands of Canterbury were originally opened for sale at $£_{3}$ an acre, later at £2. The purchaser selected and applied for his land, and, on payment of the price, received a license to occupy. The land was then surveyed and a Crown grant was issued. The price was high as compared with the price of land in other parts of the Colony, and was 
expressly designed to insure close settlement, in accordance with the Wakefield policy.

How then was it possible to acquire large holdings? The explanation lies in the fact that until land was purchased from the Crown it could be rented for pasturage purposes at a nominal rental of $£_{I}$ per Ioo acres. A tenant pasturing sheep under these licenses held the land subject to the right of any settler to select and pay the Government for any part of it; whereupon the sheepfarmer's license ceased as to that part. His occupancy was intended to be temporary, and subordinate to the claims of the farmer when the farmer should arrive.

But the wishes of the sheepfarmer by no means coincided with the intentions of the founders of the Struggle province. It was not long before a between Squat- limited number of squatters held imters and Small mense areas - indeed all the best lands Farmers of the province - under licenses to depasture. They next directed their efforts toward retaining possession without purchasing the land. In this they succeeded to a large extent, as is shown by the great holdings in Canterbury, which have descended to the present generation like the lands of the great county families in England.

The methods adopted were as various as they were ingenious. For example, for each shepherd's hut they received by law what was called a pre-emptive right over $5^{0}$ acres besides a homestead pre-emptive right over 250 acres. For every 38 I-2 chains of wire fencing erected they received a pre-emptive right over 50 acres. The squatter was thus granted the first right to buy the areas in question, but without being compelled to do so for a number of years, so that by running subdivision fences up all the watered valleys and across all 
open flats nearly the whole ranch could be secured against purchase by outsiders.

"Gridironing " consisted in buying a series of 20-acre sections so surveyed as to leave I9 acres unbought between each two sections bought; and as no one could buy less than 20 acres without going to auction, the alternating 19-acre sections were left to be occupied by the runholder.

"Spotting" consisted in buying small sections of from 20 to 100 acres so as to include all the available creeks, rendering the adjoining ridges secure from purchase owing to lack of water. A close watch was kept on strangers, and if it was supposed that they desired to purchase any piece of land, the runholder sent post haste to the land office and forestalled them. One writer has said that " a man wanting a bit of land had to take as many precautions as he would in Scotland to stalk a stag in a well-preserved deer forest." A settler was looked on as an intruder and a mean fellow, if he outwitted the runholder and secured a piece of land which the latter was supposed to occupy merely pending closer settlement. When a "cockatoo," as the small settler was called, managed to secure land, the runholder took care to leave a narrow strip of land between their holdings so that the whole cost of fencing must be borne by the "cockatoo."

For a long time the political power was in the hands of the large landholders, who made the laws and spent the public funds on roads which fronted their lands. In some ways they encour- Political Power: aged immigration, but were unwilling of the Squatters to cut up their estates and sell the land to small farmers, even at a high price. They had the English idea of building up a great landed estate and 
founding a family. Newcomers, in their view, should settle in the back blocks, as they had done, for there was still much unoccupied land, particularly in the North Island. Why should immigrants who knew nothing of pioneer life be allowed to dispossess the old settlers, who had built up the country? Besides, sheep farming was an industry that should be carried on on a large scale, and much of the land was not well suited to agriculture. In fact, it must not be thought that all of the argument was on the side of the small farmer, for it would not be difficult to present a plausible case for the large landholders, who think that they have been very badly treated and that the Dominion would have been just as prosperous if they had been let alone and if the country had been allowed to develop in the natural way, without any governmental interference.

But immigrants continued to arrive in large numbers; the number of small farmers increased; also the number of shepherds and agricultural labourers; Political Power who, with the workers of the towns
of the Small of the Small and the small shopkeepers, formed a
Farmers strong and growing party, whose interests were largely opposed to those of the large landholders, and who, when they obtained the political power in 1890 , under the leadership of Ballance, proceeded to apply a series of legislative remedies to the evils of land monopoly. (Reeves, "State Experiments," Ch. 2; Ch. 6.)

\section{A. THE LAND FOR SETTLEMENTS ACTS}

Measures were introduced by Rolleston, Sir George Grey, and Ballance, at various times, having for their

Compulsory Purchase and Subdivision object the acquisition and cutting up of large estates for closer settlement. But "The Land for Settlements Act, I892," 
which was passed under the guidance of the Hon. (afterwards Sir) John McKenzie, forms the substantial starting-point of this policy. This Act " authorized the purchase from private individuals of suitable properties for subdivision into small farms not exceeding 320 acres in extent." (Year-Book, I894, p. 204.) The Government was authorized to expend $£_{150}, 000$ a year in this manner, but there was to be no compulsory purchase. In debating the bill in the Council, the Hon. E. C. J. Stevens, of Canterbury, said:

"I am glad to hear the honourable gentleman's assurance that he did not mean that in the near future, or at any other time, it was intended to seize land compulsorily. . . . My own view is that, so long as there is any land belonging to the Crown, and so long as there is a prospect of acquiring land from the natives, it would be infinitely better to exhaust that chance of obtaining land for the people before resorting to any steps of this character. . I I do not think that the Government will be successful in obtaining bargains, and, if it is not successful in obtaining bargains, then there will be no increment enjoyed by the farmer in any degree commensurate with that which he would obtain if he settled on the waste lands of "the Crown." (Parliamentary Debates, Vol. 78, p. 319, Sept. 23, 1892.) Referring to the Act of 1892 , the Year-Book for 1894 says: "An extension of the provisions of the Act would prove beneficial in providing homes for a large class of persons, who, from inexperience or other reasons, are in a measure prohibited from occupying the waste lands of the Crown; and, moreover, as the properties acquired are all more or less improved, they seem to afford to the smallfarmer class of the Old Country an opening for building up homes for themselves where their previous experience will be of use, instead of having to learn - often by sad experience - the methods adapted to a new and wild country."

The Government found, as Mr. Stevens had prophesied, that it was difficult to purchase suitable estates on "reasonable" terms. The Act of I 892 was therefore repealed and "The Land for Settlements Act, I894," was passed, giving the power of compulsory

The Land for Settlements Act, 1894 purchase in cases where the Board could not agree with the owner as to terms of sale, the amount payable to the owner to be decided by a Compensation Court with 
full powers. Also, the amount which might be expended yearly was increased to £250,000. (Year-Book, I895, p. 253.)

The Act has been amended a number of times, was consolidated in 1900, and again in 1908. The amount which may be expended yearly is limited to $£ 75^{\circ}, 000$. Properties are purchased under the advice of a Board of Land Purchase Commissioners. The lands are divided into small farms, and leased at a 4 I-2 per cent. rental on a capital value sufficient to cover the total cost of the estate, including cost of survey, roads, etc. Formerly a lease in perpetuity was given, but now the lease is for 33 years with a perpetual right of renewal for successive terms of 33 years on a rent to be determined by revaluation.

Where the price could not be agreed on, it was formerly fixed by a judge of the Supreme Court and two assessors, one chosen by the Government Valuation by and one by the owner, but this system Self-assessment proved highly unsatisfactory; the litigation was protracted and costly; and there was a flagrant conflict of opinion between alleged experts as to the value of the land. For example, in the case of the last estate acquired under this system, there was a difference of no less than $£_{30}$,ooo between the average valuations of the property by the Government and the owner, the average of the Government's valuation being $£_{100,000}$ and that of the owner $£_{130,000}$. To overcome these difficulties it was enacted in I 908 that the compensation payable to the dispossessed owner should be the unimproved value of the land as appearing in the valuation roll upon which the owner has been paying rates, plus Io per cent. of the total value up to $£_{50}, 000$, and an additional 5 per cent. on the value in excess of that 
amount. The amount payable for improvements is still estimated by the Compensation Court. To the total amount so ascertained another 2 per cent. is added by way of compensation for the compulsory taking. (YearBook, I909, p. 666. Land for Settlements Act, I908, Section 3I.)

Naturally, this system of compensation disgusts the large landowner and vastly amuses the proletariat. The "wool-king" is placed upon the horns of as pretty a dilemma as ever was constructed. If he seeks to have his property valued at a low figure he reduces the amount of his land tax but increases the risk of its being purchased by the State for closer settlement. If, on the other hand, he increases his valuation, as he may do, he avoids the risk of being expropriated, but subjects himself to high rates and taxes.

This method of self-assessment is not new in New Zealand, for something very similar was contained in "The Land and Income Assessment Act,

I891." According to this Act, if the owner was dissatisfied with the Government's valuation, he could call on the

Commissioner to either reduce the valuation to the owner's estimate, or to purchase the property at that valuation. The classical example is that of the Cheviot Estate, consisting of 84,755 acres, which was purchased by the Government in the year I 893 for $£ 260,220$. The property had been assessed under the Act at $£_{304,826 \text {, }}$ but the trustees of the estate objected to the valuation and addressed a letter to the Commissioner of taxes, calling upon him to reduce the valuation to their valuation of $£ 260,220$, or to take the property at that price. Four special valuations were then made, all of them higher than the trustees' valuation, and the Government took 
over the property at that price, and proceeded to divide it among a large number of tenants. The trustees were very much dissatisfied at being out-bluffed by the Government. Many of the tenants got leases which have since greatly increased in value and have made small fortunes out of their holdings. On March 3I, I909, there were 312 tenants holding 75,584 acres of this land, and paying a yearly rental of $£_{14,587}$. The investment has been a fairly good one for the Government, but excellent for the leaseholders. (Year-Book, I895, p. 264. Year-Book, I909, p. 5i6.)

The number of properties acquired by the State under the Land for Settlements Act, up to March 3 I, 1909

was 187 . The total area acquired was Lands Acquired I, I95,29I acres, and the total cost to and Divided the State, including the cost of roads, was $£_{5}, 599,680$. The total income for the year, in rents and interest, was $£ 250,623$, while the interest paid for the money borrowed was $£ 2$ I 5,828 , giving a balance of $£ 34,795$. The total number of tenants was 4,413. (Year-Book, I909, pp. 516-524. Public Accounts of New Zealand, I909, pp. I04-I09.)

The lands are leased in areas of 640 acres of first-class land, and in areas of 2,00o acres, when the land is of the second-class. Of the total area, 678,923 acres are held under leases in perpetuity, I55,982 acres under renewable lease, and 218,735 acres under small grazing-run leases and short tenures. The properties have all been purchased with money borrowed from abroad. The interest on these loans must be remitted to the foreign bondholder, and the only surplus which accrues to the State is the difference between the rents received and the interest paid on the loans plus the incidental expenses. Up to March 3I, I909, this difference was a 
minus quantity, since the rents received were $£_{1}, 7$ I0,032, while the Interest paid was $£ I, 33 I, 980$, and the incidental expenses were $£ 452,68 \mathrm{I}$. The balance shown in the accounts, and the sinking fund deposited with the Public Trustee have evidently been derived from loans. (Year-Book, I909, p. 522.)

The administration of the Act, therefore, has involved a loss to the Government, although closer settlement has been promoted and many small farmers have been greatly benefited. In the words of the Year-Book:

"The acquisition of lands under the Lands for Settlement Act has proved beneficial in providing homes for a large class of men of moderate capital who shrink from the rough work of breaking in a new country, or who, having accumulated capital, prefer open country near civilization."

The main defect in the policy is that the Government has not tried to make a profit out of the transactions, but has administered the Act for the benefit of the small farmers with too little regard for the interests of other classes of the

Defects of the Policy people. Had the lands been leased under

a system which allowed of reappraisal of the rents at stated intervals, as under the renewable lease established in 1907 , the State might have thus secured the " unearned increment." Or, had the tenants been allowed to purchase the freehold of these lands, the State could have devoted the proceeds of the sales to the purchase and division of other estates, and this process might have gone on indefinitely, without borrowing so much money from abroad, while the freeholders would have been more contented than the present leaseholders are, and might have contributed something to the public revenue by way of a land-tax. The renewable lease is a vast improvement on the lease in perpetuity, but does not lessen the need for continual recourse to the foreign money-market for further loans. 


\section{4 STATE SOCIALISM IN NEW ZEALAND}

The difficulties in the way of continuing the policy of purchasing large estates are increasing year by year. There has been during recent years

Temporary

Policy

a marked rise in land values due partly to high prices for staple products, such as wool and mutton, partly to the building of railways and other public works, and partly to the State's entering the market as a large buyer of land. The result has been a boom in land values. Every year it becomes more difficult for the State to buy land at a price which will allow of subdivision and leasing at rentals which tenants can afford to pay. So the State cannot go on indefinitely investing millions in land and remitting the greater part of the rents abroad by way of interest. Also, as has been shown, a large State tenantry is a political force, and just as they have clamored for the freehold so in times of depression they may clamor for a reduction of their rents and thus imperil the financial stability of the Dominion. Speaking in 1907 Sir Joseph Ward said:

"I would like to ask how many honourable members are prepared to continue obtaining loans year after year in order to carry on the lands for settlement on the present system. There is not a member of the House who, realizing his responsibilities, will contradict me when I affirm that it would be impossible for the Colony to go on borrowing and spending $£ 75^{\circ}$,000 a year by the issue of debentures in order to acquire fresh lands for settlement. The position is an impossible one."

In the same year the attorney general admitted that the State had to pay too much for a great part of the land taken, and that, in a time of depression, either the Crown tenant would have to pay more rent or else ask the State to take the burden from him. How the tenant was to pay more rent in times of depression the AttorneyGeneral did not explain, and the only conclusion is that the loss would fall on the State. 
Summing up the results of the land-for-settlements policy, it may be said that while it has placed many settlers on the land it has done so at too great a cost and at too great a risk to the community. For these reasons the State has recently turned its attention to another method of inducing subdivision - the progressive taxation of large estates.

\section{B. THE GRADUATED LAND TAX}

It seems likely that the graduated land tax will be increasingly used as a more rapid and less costly means of bringing about closer settlement. Closer SettleThis method was first adopted in r891, ment without but before the year 1907 the scale of taxation in force had no very marked effect

Cost to the Government in breaking up the large estates. The tendency in this direction was largely negatived by family subdivision and other methods of evasion. The ingenuity displayed in avoiding the tax was worthy of the best traditions of the legal profession. The Hon. Robert $\mathrm{McNab}$ in a recent speech gave an interesting example. A man with $£_{50,000}$ worth of land would subdivide it into five parts and make a bogus sale of four parts to four of his shepherds for $£_{10,000}$ apiece. The supposed buyer paid $£_{5}$ on account and gave the owner a mortgage for $£ 9,995$. When the officer who purchases land for closer settlement called, he was referred to the four shepherds as owners. The individual areas were useless for subdivision after the shepherds had retained the areas which by law they were entitled to retain on purchase by the State. Thus the real owner escaped from the operation of the Land for Settlements Act. When the taxation officer arrived to ask for the graduated land tax, he also was referred to the shepherd, who admitted that the land belonged 


\section{STATE SOCIALISM IN NEW ZEALAND}

nominally to him, but claimed to have no graduated tax to pay since he was entitled to deduct from the total value the value of the mortgage of $£ 9,995$. The shepherd, of course, could not pay interest on the mortgage, so he leased the property to the mortgagee, the rent being fixed at the same amount as the interest on the mortgage. Furthermore, the mortgage moneys became due on demand and the real owner could at any time resume possession. Meantime the owner's sheep grazed all over the property, and everyone was happy except the tax gatherer. (Parliamentary Debates, Vol. I4I, p. 58, Sept. I 8, I907.)

The Hon. Dr. Findlay, the Attorney General, explained no less than eight different devices for evading the tax. It was known that the State

Evasions lost $\mathfrak{E I}_{\mathbf{9}}, 000$ in two years by these expedients. What the total loss was cannot even be guessed. The chief means of evasion were bogus partnerships, one-man companies, collusive sales and leases, declarations of trust, and nominal gifts. A common device, of course, was to cut the property up amongst members of the family but to continue to work it as one estate. (Parliamentary Debates, Vol. I4I, p. 486, Oct. Io, I907.)

The Land and Income Assessment Act, I907, was designed to prevent evasion as well as to bring about a further subdivision of large estates. The Increasing the tax is so high on large estates that it Graduated Tax will either compel the owners to sell their property or it will largely augment the revenue from land taxation. The following example will show the effect of the new law. Under the old system an estate of the unimproved value of $£_{140,000}$ might be nominally subdivided among a family of ten who would then pay graduated tax at 5-16d. in the 


\section{LAND MONOPOLY}

pound, which would amount each year to a little over £I82. Under the new Act the estate would be treated as a single estate, and would be taxed at $4 \mathrm{I}-5 d$. in the pound, which would yield a yearly contribution of $£ 2,450$, since joint owners are assessed jointly and severally and joint occupiers as if they were joint owners.

On an estate worth $£ 200,000$ the graduated tax is 2 I-2 per cent., and this, with the ordinary land tax in addition, would amount to $£_{5}, 833$. If the owner lived out of New Zealand and came within the definition of an absentee, his total tax on such a property would be $£ 8$,$750: 15$ s., or 3.15 per cent. on the unimproved value.

The. following table affords comparison between the old and the new rates, to which in every case should be added the ordinary land tax of $\mathrm{I} d$. in the pound, and, in the case of absentees, 50 per cent. should be added to the graduated tax: (Parliamentary Debates, Vol. I4I, p. 39.)

\begin{tabular}{|c|c|c|}
\hline Unimproved Value & $\left|\begin{array}{c}\text { Graduated Tax at } \\
\text { Old Rate }\end{array}\right|$ & $\begin{array}{l}\text { Graduated Tax at New Rate } \\
\text { Increased by } 25 \text { per cent. }\end{array}$ \\
\hline 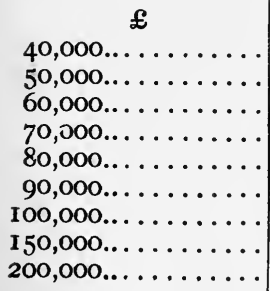 & $\begin{array}{l}\text { \& } \\
\mathrm{I} 45 \\
208 \\
28 \mathrm{I} \\
365 \\
458 \\
562 \\
677 \\
\mathrm{I}, 407 \\
2,396\end{array}$ & $\begin{array}{r}£ \\
200 \\
313 \\
450 \\
612 \\
800 \\
1,012 \\
1,250 \\
2,813 \\
5,000\end{array}$ \\
\hline
\end{tabular}

The land tax, together with other legislation and the natural tendency toward the division of large estates, a tendency not so strong in pastoral as in agricultural countries, has doubtless had some effect in reducing the size of

Effects of the Tax the great estates. The Official Year-Book says: 
"It would appear that there has been a reduction in the total held in areas of ro,000 acres and over of $2,797,85^{8}$ acres during the period $1889-1906$. Purchases by Government contributed to this result, but only to the extent of about one-third, voluntary subdivision accounting for the balance. The average area held by owners of 10,000 acres and upwards shows a steady decrease since 1889, as follows: (Year-Book, 1909, p. 448.)

Year

Average area held

r 889 Acres

1892 30,009 .. 29,924 1906.

28,312

An official return presented to Parliament during the session of 1906 showed that there were 63 rural estates with an unimproved value of $£ 50,000$ and upward, I4 with an unimproved value of $£$ I00,000 and upward, one estate of 2 I 8,866 acres valued at $£_{21} 4,978$, and one of IOI,22 I acres valued at $£ 276$, I I 8 . The capital value of these great estates was $£ 296,990$ and $£_{335,405}$. It is misleading to quote values for purposes of comparison, because land values have risen greatly in the last decade. The great estates show a considerable decline both in number and acreage. In I 896-97 there were $50 \mathrm{I}$ holdings of 10,000 acres and over, containing 54 per cent. of the total acreage of occupied lands, and in I908o9 there were 470 of such holdings, containing 43 per cent. of the total acreage. In $1896-97$ there were I 12 holdings of 50,000 acres and over, comprising 30 per cent. of the total acreage, while in 1908-09 there were only 84 estates of this class, comprising only 22 per cent. of the total acreage. (Year-Book, 1909, p. 443.) The following figures as to acreage show a considerable reduction in the number of great estates since 1892 : (Government Valuation of Land Department, I907, B. I7A.) 
Acres

Io, 000 and under

20,000 and under

30,000 and under

40,000 and under

50,000 and

75,000 and under $100,000 \ldots \ldots \ldots \ldots \ldots$

Ioo,000 and under $150,000 \ldots \ldots \ldots \ldots \ldots . . . . . .$.

150,000 and over.....................

Total holding over 100,000 acres.....

\begin{tabular}{rrr}
\multicolumn{4}{c}{ No. of Owners } \\
1892 & 1902 & I906 \\
148 & 123 & 129 \\
45 & 40 & 40 \\
30 & 21 & 14 \\
9 & 9 & 8 \\
14 & 12 & 8 \\
6 & 6 & 4 \\
4 & 2 & 0 \\
6 & 3 & 1 \\
\hline 262 & 216 & 204
\end{tabular}

The new taxes imposed by the Act of 1907, of which the full amount was not to be levied until I9IO, will be a heavy burden for the owners of estates

having an unimproved value of $£ 40,000$ Heavy Taxation and over, and will surely compel them to of Large Estates sell or otherwise divide their holdings.

In fact, a number of estates already have been cut up. (Parliamentary Debates, Vol. I47, p. 7 I9, Oct. 29, I909.) Naturally, these measures have been hotly assailed by the large landowners. A newspaper which supported the new law was accused in its own columns of "doing its best to turn a colony of self-reliant, hardworking people into a race of slouching cadgers who in another generation will want to give up work altogether for the congenial pastime of filching the property of those who have anything left to be stolen, if the latter have not already left the country." The Hon. Henry Scotland said in the Council:

"Sir, this is a socialist bill. I suppose it is only the first of many socialist bills. We shall have plenty of them by-and-by" until we shall have frightened capital, we shall have induced all employers to go into the Bankruptcy Court, and the English money market will be closed against us. . With regard to the large landowners, I think we ought to bear in mind that they have not been the unmitigated curse some people would make them out to be to the colony. Who started the frozen meat industry? Did those blethering trades-unionists and socialists start it? No. It was started by these despised and persecuted landowners." (Parliamentary Debates, Vol. I4I, p. 494, Oct. I0, 1907.) 


\section{LIMITATION OF AREAS}

During the session of 1906 the Government brought in a bill to limit the holdings in rural lands of any individ-

Proposal to

limit Size of Holdings

ual or company to an unimproved value of $£_{50,000}$. The bill met with strong opposition and was dropped. By "The Land Laws Amendment Act, 1907" it was made illegal to acquire from the Crown any land, if such land, together with all other land owned or occupied by the applicant under any tenure, would exceed 5,000 acres of third class land, 2,000 acres of second class land or 640 acres of first class land. ${ }^{\mathrm{I}}$ The result is that any land sold by the State after 1907 will not be freely marketable by the owner. He cannot sell to anyone who would thereby acquire more than the area which he is entitled to hold. Very stringent provisions are inserted for enforcing compliance with this law. (Land Laws Amendment, 1907, Sections 36, 93-100.)

There can be no question that the people as a whole approve of the attempt to disintegrate the large estates. The motive can hardly be said to be that of expropriating the capitalist as a capitalist, for no serious agitation has been made to increase the income tax. The chief arguments for the special taxation of land are that there is a limited area and that a large part of it is held by a few persons. The small landholders are not taxed at all. The Austrian economist, Menger, has noted that in England the socialist movement directs its main attack against landed property and concerns itself but little with profits and property in capital, while German socialists see in movable capital and interest the root of all eco-

${ }^{1}$ First-class land is land of an unimproved value of $f_{4}$ an acre or upwards. Second-class land is land worth from $£_{2}$ to $£_{4}$ an acre. Third-class land is land worth less than $f_{2}$ an acre. 


\section{LAND MONOPOLY}

nomic evil. In this respect New Zealand is more like England, where landed property is concentrated in a few hands, and the people are determined that there shall be no great landlords, as in England, and no absentee landlords, as in Ireland.

Some writers have predicted that the appetite for reform by taxation will grow, and that the taxation will be increased and the exemptions diminished until all the rentwill be taken and theland practically confiscated, according to the proposals of Henry George. But the land-

Small Farmers opposed to Socialism less man, when he becomes a landholder, ceases to be a single-taxer and is strongly opposed to socialism. The land legislation of New Zealand, although apparently socialistic, is producing results directly opposed to socialism by converting a lot of dissatisfied people into stanch upholders of private ownership of land and other forms of private property. The small farmers, then, are breaking away from their former allies, the working people of the towns, who now find themselves in the minority, but who are increasing in numbers and who will demand, sooner or later, a larger share in the product of industry as the price of loyalty to the capitalistic system. 


\section{CHAPTER IV}

\section{ROADS AND RAILWAYS}

The early European settlements in New Zealand, like those in America, were established on or near the sea-coast, with a rugged and almost inaccessible back country, into which the settlements extended by means of roads. The numerous rivers, few of which were navigable, were a hindrance rather than a help to communication, particularly in time of flood, when bridges were carried away, fords rendered impassable, and even ferries were not to be relied upon. Because of the abundant rainfall, varying from twenty inches or less in the interior of Canterbuty to one hundred inches or more in some parts of the West Coast, ordinary unmetalled roads were quite us: less for wheeled vehicles during many months of the year. People travelled on foot, on horseback, or by bullock sledges that moved along at a snail's pace through mud and mire. In remote parts of the Dominion these primitive conditions have continued to the present day. "This may be God's own country," said a settler in one of the back blocks, " but we have the devil's own roads."

The early settlers fully realized their need of roads, and their leaders sought to provide funds for making them. Edward Gibbon Wakefield, the founder of the New Zealand Company, held that the Company's land should be sold at a "sufficient" price, and that the revenue therefrom should be spent on immigration and public works, chiefly roads and bridges. (Reeves, State Experiments, Vol. I, Chap. 6.) In the company's 
settlement at Wellington the price of land was fixed at $£_{I}$ an acre. The Canterbury Association, which bought a large quantity of land from the Company, at first sold it to settlers at $£_{3}$ an acre, but the price was soon reduced to $£ 2$. From 1853 to 1873 the Province of Canterbury sold I,IOI, 583 acres of Crown lands, for which it received $£ 2,203,166$, a large part of which was spent on roads and bridges. At first the making of roads was in the hands of the Provincial Council, but in the year I 863 road districts were created, governed by boards elected by the rate-payers, and having power to levy rates for the construction and maintenance of roads. But the Provincial Council continued to spend large sums of money on certain important works, and gave, besides, large grants to the road boards. (Handbook of 1875 , article by W. M. Maskell.)

The Province of Otago and all the other provinces adopted a similar policy, and were more or less active in the construction of roads, deriving their funds from taxation, as well as from the sale of crown lands, but in the year 1876

Importance of Roads the provincial governments were abolished, and the Crown lands were taken over by the general Government. From this time the construction and maintenance of roads was chiefly in the hands of the road boards, counties, and other local governing bodies, but large subsidies were granted them by the general Government, which also carried on important works of its own for the opening of new districts and the improvement of those already settled. From the year I870 to March 3I, I900, the sum of $£ 8,33$ I, or 6 was expended on roads out of the Public Works Fund, and doubtless a far greater sum was spent by the various local bodies. (Public Works Statement, 1909, p. 3.) Probably not less than $£ 25,000,000$ 
has been spent upon roads and bridges from the beginning of the Colony until the present time. A large part of this amount has been procured by loans, the general Government alone having borrowed more than $£ 6,000-$ ooo for this purpose; another large part has come from the sale or leasing of Crown lands; and a third part, also large, has been derived from taxation. That the development resulting from this expenditure has many times repaid the outlay is sufficiently shown by the fact that the unimproved value of land in the year 1909

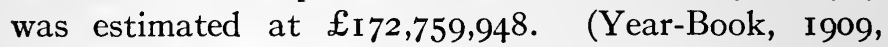
p. 557.) Whether the benefits derived from this expenditure have been equitably distributed among the people in different parts of the country is another question.

The activity of the provincial governments in the building of roads was obviously due to their control over the Crown lands, as well as to the fact

Roads and

Land Values that the settlers had not capital sufficient for enterprises of such magnitude. For the same reason, when railways were projected, the people naturally expected the provincial governments to provide the money, either from the sale of Crown lands or from loans effected in England on the security of the public credit, which was largely dependent on the value of lands, public and private. Private companies, perhaps, might have been formed if the provinces had been willing to guarantee their debentures or to make large grants of public land; but there was no large supply of private capital in the colony, and no attractions sufficient to induce British capitalists to engage in what must have seemed to them small and unpromising enterprises.

The first railway in New Zealand was undertaken by the Provincial Government of Canterbury in the 
year $\mathbf{1} 860$ for the purpose of connecting the town of Christchurch with the port of Lyttelton, from which it is separated by a high range of hills. At this time the Private Capital not Obtainable total population of the Colony, exclusive of Maoris, was barely 80,000 , while the population of Canterbury was not over 20,000 . The opening of the first part of the line, between Christchurch and Ferrymead Junction, was celebrated with great rejoicing on December I, I 863, and the great tunnel, over a mile and a half in length, was opened on December I, I867. It was an important work, connecting the capital city and the interior of the Province with the magnificent harbour of Lyttelton, and without it the development of the Province would have been retarded for many years. A little later the Province built another line, running southward from Christchurch to the Selwyn River. (Handbook of I892, article by E. G. Pilcher.)

In 1863 the Provincial Council of Auckland began the construction of a line between Auckland and Drury, chiefly for the purpose of subduing the Maoris of the Waikato, but with the idea of ultimately completing a main trunk line to Wellington. In the same year the Provincial Council of Southland (reunited to Otago in I870), obtained from Parliament an Act authorizing the construction of the Bluff Harbour and Invercargill Railway, which was opened on February 5, 1867. To this period belongs also the Dunedin and Port Chalmers Railway, constructed by private capital under the guarantee of the Otago Provincial Council. There were in the whole Colony only 46 miles of open railways in 1870 , when Vogel's celebrated public works policy was promulgated. In 1872 there were only 65 miles of provincial railways; in 1875 there were only 70 miles open; and 
when, in 1876 , the provincial governments were abolished and their public works were taken over by the general Government, the total amount spent by them on railways, including the cost of the Dunedin and Port

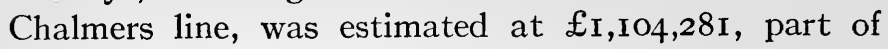
which was debt, and was assumed by the general Government. (Handbook of 1875, article by John Knowles; Year Book of I908, p. 579.)

From I 860 to 1870 the European population of New Zealand was trebled, having increased from 80,000 to 250,000 , notwithstanding that there were almost no railways. But people began to feel more and more their need in this regard. The provinces had made a good beginning, but there was no prospect of the rapid growth of their railway systems. In fact, there was no system at all, but only a few disconnected spurs issuing from the chief towns. There was a difference, too, in the gauge, Canterbury having adopted the Irish gauge of 5 feet, 6 inches; Otago and Auckland the standard English gauge of 4 feet 8 I-2 inches; while the Government, following the advice of Robert Stephenson, recommended a gauge of 5 feet, 6 inches, but afterwards adopted 3 feet, 6 inches, as the uniform gauge for the whole Colony. If the provinces had gone on with their work, it is probable that there would have been two, if not three, different gauges, with all the resulting inconvenience and loss that Australia has suffered from this cause. But the provinces, with their limited resources, could not command the capital necessary for extensive construction. This was obviously a matter for the general Government to undertake. The time had come for a forward movement, and it was at this opportune moment that Mr. (afterwards Sir) Julius Vogel, proposed his remarkable scheme of colonial development. 
Although the population of the Colony in 1870 was only 250,000 , Vogel, who was as much gambler as statesman, proposed to borrow within the next ten years the enormous sum of Policy of Vogel $£$ ro,000,000, to be expended in specified proportions on immigration, railways, roads, purchase of native lands, water races for the gold fields, and extension of telegraph works. (Handbook of I875, article by John Knowles; Handbook of I892, article by E. G. Pilcher.) As a matter of fact, twice the proposed amount was borrowed, for the public debt within the next ten years increased from $£_{7,841}$, 89I to $£ 28,185,7 \mathrm{II}$, while the population increased from 250,000 to 500,000 , so that there was an increase in debt per capita from $£_{32}\left(\$_{155}\right)$ to $£_{56}(\$ 272)$.

The debt would not have been so large if Parliament had adopted the whole of Vogel's plan, for he suggested with great wisdom that the Crown lands Deviations from be so administered, by lease or sale, as to Original Plan, pay a large part of the cost of the roads through Politiand railways, and that a special tax be cal Influence levied on the owners of lands specially benefited. (Reeves, New Zealand, in the Story of Empire Series, p. I44; Parsons, The Story of New Zealand, chap. I8.) But provincial and local influence was too strong for Vogel. Parliament, after a great debate, almost unanimously agreed to the alluring proposals involving the borrowing and spending of vast sums of money; but rejected measures which were designed to operate as a check upon excessive borrowing, and which would have compelled the land-owners to pay part, at least, of the burden they were so eager to shift to the shoulders of a future generation. It was no mere coincidence that Parliament was at that time chiefly composed of land-holders, among whom the sheep-raisers of the South Island exercised a 
dominating influence. The Immigration and Public Works Act of 1870 and cognate Acts were passed, and the Colony entered upon a rapid career of borrowing, expenditure, and internal development.

The Government had a comprehensive plan of railway construction, involving the completion and extension of lines already begun, so as to make ultimately two main trunk lines running the length of both islands, with feeders into the interior wherever a profitable traffic could be developed. But the pressure of local influence was so great as to compel many deviations from the original plan. In some districts railways were built far in advance of requirements, while in others people waited long for lines that might have been immediately profitable. Sir Julius Vogel desired and expected the railways to pay at least the cost of maintenance and interest on the borrowed capital (about 5 I-2 per cent.), but from every part of the colony arose a clamour for a "fair share" in the public expenditure, and appropriations were doled out to more than thirty different districts, with undue regard to political inflence. (Handbook of 1875 , article from the New Zealand Times.) No doubt the districts having the greatest political influence were, as a rule, the most populous, but not necessarily the most promising or in greatest need of development. To such perversions of the original plan may be traced much of the financial failure in railway administration from the beginning until the present time.

The Government was active in the building of railways from 1873 to 1877 . In the former year there were,

Rapid

Construction at First in all, 145 miles of open line and 434 miles under construction. In 1877 there were $\mathrm{I}, 052$ miles of open line and only $25 \mathrm{I}$ miles under construction. (Handbook of 1879, by James Hector, p. 8I I.) These were 
narrow-gauge lines, with severe gradients and sharp curves, light rails and cheap bridges, " designed with a view to the early production of revenue, and at some sacrifice of convenience in travelling and in working." Most of these lines were built by contractors, at a cost of about $£_{7,000}$ a mile. (Handbook of 1892 , article by E. G. Pilcher.)

The development of the Colony which followed the inauguration of the Public Works Policy was considerable, though not so substantial as many have thought. The population increased by 74 per cent. from I 87 I to 1879 . In the

Development and Inflation previous eight years it had increased by 62 per cent. The value of the exports did not increase much, perhaps because of the world-wide industrial depression after 1873 . The value of the imports increased at first, but afterwards fell. There was a great excess of imports from 1872 to $I 886$, due chiefly to the importation of borrowed capital, and after that year there was a large excess of exports ("Fifty Years of Progress in New Zealand"; Year-Book of I909, p. 637). The value of land, especially the lands opened up by the railways, increased enormously. Sir James Hector says:

"Hundreds of thousands of acres, worth, before the advent of railways, from $£_{1}$ to $£_{3}$ an acre, were afterwards sold at prices ranging from $£_{10}$ to $£_{20}$ per acre." (Handbook of 1879, p. 80.)

A violent land fever or "boom" ensued, which collapsed in 1879 , and from which the Colony did not recover for many years. Mr. Reeves says: "The boom burst amid much suffering and repentance. In some districts three-

Collapse of the Boom

fourths of the prominent colonists were ruined, for the price of agricultural produce continued, on the whole, to fall relentlessly year after year until r 894." (New Zealand, p. I48.) Mr. Reeves also says: 


\section{STATE SOCIALISM IN NEW ZEALAND}

"It was not the public borrowing of the Colony, but the private debts of the colonists, which, following the extraordinary fall in the prices of their raw products between 1873 and I 895 , plunged so many thousands into disaster. . . New Zealand is now a pleasant and highly civilized country. That she has become so in the last thirty years is due chiefly to the much criticized public works policy." ("New Zealand," p. I50).

While this is partially correct, and the crisis of 1879 was only the inevitable culmination of a period of development and inflation that began as early as 1860 , it is certain that the vast and rapid expenditure of borrowed money by the Government acted as a powerful stimulant to private speculation and borrowing at a time when retrenchment should have been the order of the day; and, while it postponed the coming crisis, greatly increased its violence when it did come. Besides, the unwise distribution of public expenditure, especially in the building of unprofitable railways, tended to limit the power to borrow later on for profitable investments, and thus retarded the development of the country.

In the four years from 1873 to 1877,907 miles of railway were completed, making an average of $25 \mathrm{I}$ miles a year. In the ten years following, 7or miles were built; in the next ten years only 304 miles; and in the ten years ending March 3, I908, only 416 miles were completed; not because the Colony had all the needed railways, nor because none of the projected lines were likely to pay, but chiefly because of the inability of the Government to borrow adequate sums; and this may be traced to the unprofitable character of the lines already built.

The activity of the Government in railway construction, and the unwillingness of the people to give concessions to private syndicates, effectually

Private Railways prevented private capital from engaging in railway enterprises. The Wellington and Manawatu Railway Company is a notable exception to this rule. In the year I 878 the 
Grey Government, after careful surveys, decided to build a line between Wellington and Foxton, as an important part of the line between Wellington and New Plymouth on the way to Auckland. After about $£_{30,000}$ had been spent, the work was discontinued, and a royal commission in 1880 reported against the line. Thereupon some enterprising citizens of Wellington took the matter up, and, being assured by the premier that the Government had no money to carry on the work, but would grant concessions, they formed a company in $\mathbf{I} 88 \mathrm{I}$. The work was vigorously prosecuted, and the line between Wellington and Longburn, $84 \mathrm{I}-4$ miles in length, was opened on December 3, I886. By "The Railways Construction Act, I88I," Parliament made a grant of land to the company to the extent of 30 per cent. of the cost of construction, provided that this cost did not exceed $£_{5,000}$ per mile. The value of land receivable under this contract amounted to $£_{126,375}$. Through neglect of the Government the company received land of the value of only £IoI,909-about 215,000 acres. (Annual Report of the Wellington and Manawatu Railway Company, I906; Year-Book, I905, pp. 38I-384.)

The Wellington and Manawatu Railway Company has been very successful. It opened up a fine pastoral country tributary to Wellington, and sold its lands at good prices. It gave a service that compared favourably with that of the Government, and at

Success of the Manawatu Railway the same rates. It diverted a good deal of traffic from the Government's line, which reached Wellington by a detour of 134 miles in place of 84 miles by the Manawatu. In fact, the Government's express trains between Wellington and New Plymouth were obliged to pass over the Manawatu line. From the beginning the company paid 
interest at 5 per cent. on its debentures. The first dividend, of 3 I-2 per cent., was paid in 189r. For the two succeeding years 5 per cent. was paid, after which the dividend was 6 per cent., and latterly 7 per cent. The company also paid for all additions and improvements out of revenue, and up to 1906 had written off the sum of $£ 202,086$ on account of railway and rolling stock. From the beginning until the year I906 the company had paid $£_{\mathrm{I} I 8,55^{\circ}}$ in general and local taxes, being nearly 20 per cent. more than the original value of the land grant. The value of governmental and private lands in the district served by the railway has greatly increased, and the company claimed to have been the chief cause of the creation of this " unearned increment."

For a long time the Manawatu Railway was a thorn in the flesh to the Railways Department, and the Government was incessantly urged to purchase the line, in accordance with the provisions of the Act of $\mathrm{r} 88 \mathrm{r}$, and so complete the railway system. This was done on December 7, 1908, the price being $£ 933$,759. (Year-Book, 1909, p. 58r.) This was enough to pay off the debentures and to give the shareholders more than the market value of their shares (48s.) at the time of the sale. On March I3, I909, it was announced that they would probably receive $60 s$. per share. The venture proved a good investment for the shareholders and the Government expects to make a profit on the transaction.

The only other private railway of any importance was the New Zealand Midland Railway, owned by an English Syndicate formed in $\mathrm{I} 886$ for the purpose The Midland of building a line from Springfield in Railway

Canterbury to Brunnerton in Westland, by way of the Otira Gorge, and thence to Nelson, a total distance of 235 miles, to complete the 
main trunk iine of the South Island. It was a landgrant railway, and under the contract of 1888 the company was to receive Ios. worth of land for every $£$ I spent in construction. It is stated that the Government did not abide by its contract, but forced the company to sell upon unfair terms. The railway was taken over by the Government on May 27, I895, after 79 miles had been constructed at a cost of about $£_{I, 300,000 \text {. (Year-Book }}$ of 1894 , article by H. M. Dalston, acting general manager; Year-Book of r896, p. 38I.) The Government has not yet completed the line as originally planned, so that Nelson and Westland are still isolated, having no railway connection with the main line of the South Island. On March 3I, I909, there were 29 miles of private railways in New Zealand, while 2,682 miles were owned and operated by the Government. (Railways Statement, I909.)

Comparisons of railways in different countries are interesting, but often misleading. New Zealand has 2.4 miles of railway for every 100 square miles of territory; New South Wales, I.I miles; Victoria, 3.8 miles; Queensland, .47 miles; Argentina, I.I miles;

General

Description and Comparisons Canada, .6 mile; the United States, 7.7 miles; Nebraska, 7.7 miles; Colorado, 5.I miles. New Zealand is better supplied with transportation facilities than these figures indicate, for most of the large towns are on the coast, and have the benefit of transportation by sea. No part of New Zealand is as much as roo miles from the sea, so that places that have no railways at all, but have fairly good roads, are not altogether isolated.

On the whole, railway development has followed a pretty well-defined plan, and there are no parallel lines. The Main trunk line, between Auckland and Wellington, 


\section{STATE SOCIALISM IN NEW ZEALAND}

after years of delay, has been completed, and was formally opened on November 6, 1908. The main line of the South Island is still far from completion. Travellers southward bound from Wellington take ship to Lyttelton, a distance of 175 miles, whence they go by rail, following closely the coast line, to the Bluff, at the southern end of the island. There are still a number of isolated bits of line, beginning at some seaport and ending at some small country station. Spurs run out at intervals from the main line, sometimes into a rich and populous district, sometimes into a thinly settled pastoral country, where little traffic can be developed.

The narrow gauge of 3 feet, 6 inches, prevails throughout. Originally, the railways were built with sharp curves, steep grades, light thirty or forty pound rails, little or no ballasting, temporary bridges, small-sized rolling stock, and very inadequate terminal facilities. Gradually, the system has been improved, and at considerable expense. The railway stations at Auckland and Wellington are still very poor, but Christchurch has a good building, and the new station at Dunedin, costing about $£ 46,000$, is excellent. The first class carriages compare favorably with cars of the same class in the United States. Second class accommodation is poor. In winter the carriages are partially heated by warmingpans, except on the main trunk line, where heating by steam has been introduced. Until recently there were no night trains, and, therefore, no sleeping-cars; but, since the opening of the main trunk line, sleeping accommodation has been provided between Auckland and Wellington. There are dining cars on the principal trains, where one can obtain a good meal for $2 s$.

On most of the branch lines the service is infrequent, seldom exceeding one train a day each way. There are 


\section{ROADS AND RAILWAYS}

two trains a day each way between Christchurch and Dunedin. For shorter distances, on the main lines, the service is more frequent. The large towns have as good suburban service as could be expected, considering their size. The speed of trains is not great, particularly in hilly districts. Ordinary trains travel from ten to seventeen miles an hour; express trains, from seventeen to twenty-five an hour. The trains are generally on time. Accidents are relatively fewer than in the United States.

Passenger traffic is relatively large in New Zealand yielding 33 per cent. of the total revenue as compared with 22 per cent. in the United States. It is difficult to make a comparison of fares, for there are no available statistics giving the average revenue per passenger-

Passenger Traffic and Fares mile. Ordinary first-class fares average about I I-2d. (3 cents) per mile, and second-class fares about I $d$. ( 2 cents), and they are the same in every part of the system. The fares for return tickets are usually double those for single tickets. About 80 per cent. of the passengers travel second-class. There are special excursion fares for schools, factories, and friendly societies, season tickets for suburban residents and school-children, weekly workmen's tickets, special rates for tourists, and minor concessions, all of which tend to reduce the average fare. It seems probable that the average fare per passenger-mile is slightly under $\mathrm{I} d$. (2 cents), and, therefore, very close to the average of the United States (2.0I4 cents). (Statistics of Railways in the United States, 1907; Passenger Fares and Coaching and Goods Rates, Wellington, 1907.)

The railways statement does not give the average charge per ton-mile; but, judging from the commodity 
rates, it is safe to say that it is not much less than $2 d$. (4 cents), and certainly not less than $1.75 d$. (3.5 cents). The ton, however, is the long ton of Freight Charges 2,240 pounds. In the United States, in the year 1906-07, the average revenue per ton of freight per mile was .759 cent. (.379d.). The system of tapering rates, involving progressively lower rates for increasing distances, is applied throughout. Goods in Class F, when shipped by the truck-load, are carried at the lowest classified rates, at a charge of $.72 d$. ( 1.44 cents) per ton-mile for a distance of 100 miles, and $.94 \mathrm{~d}$. ( $1.98 \mathrm{cents}$ ) per ton-mile for a distance of 50 miles. Lime for fertilizing, under specified conditions, is carried free for a distance of Ioo miles, but forms an insignificant part of the total freight. Goods in Class A, including furniture, sewing-machines, fancy goods, dried fruit, glassware, spirits, sugar, and a great variety of articles of general merchandize, are carried 50 miles at a rate of $7.56 d$. ( 15.12 cents). To these rates must be added extra charges, when loading and unloading are done by the Department. It should be noted also that most of the freight is shipped at the owner's risk.

The average length of haul is probably only slightly over 40 miles and this is one of the chief reasons why freight rates are so high, and why it is not quite fair to compare them with average rates in the United States, which are brought down by low charges on long-distance shipments of grain, cattle, cotton, coal, lumber, fruit, and other staple commodities. Besides, the volume of business is less in New Zealand, so that the average cost per ton of freight carried is relatively high.

As a rule, both freight and passenger rates are uniform throughout the Dominion, irrespective of the density of traffic. The Railways Department is no respector of 
persons or places. The rates on small, disconnected lines are the same as those on the main lines, and the smallest wayside station pays no more than the largest city. Beyond the published rates for carload lots, as in Class F, the largest shippers get no advantage, and

Practically

No Discrimination in Rates there are no secret discriminations. Doubtless a system of differential rating designed to favour populous districts would prove profitable, but it would cause more discussion and criticism than any administration could stand. While making some special concessions to certain localities and for the benefit of certain industries, as timber and coal, the Department, for the most part, has taken refuge in an almost inflexible system of rates, and, instead of modifying the rates in accordance with the conditions and changes of business, has compelled business to accommodate itself to the established rates, regardless of special circumstances and special needs. 


\section{CHAPTER V}

RAILWAY FINANCE

AFTER the inauguration of the Immigration and Public Works Policy of 1870 , the colonial secretary acted for a time as minister of immigration

Railway and public works. Later a special minisAdministration ter was appointed, and in $\mathbf{1 8 7 2}$ two departments were created, and the State railways were placed under the control of the minister of public works. (Handbook of $\mathbf{1} 875$, article by John Knowles.) From the beginning the railways were run at a loss, and there was much criticism of their administration. Hence, by the Government Railways Act, I887, they were placed in the hands of a board of commissioners, three in number, appointed for five years or during good behaviour, who were expected to introduce business methods and to extinguish the deficit.

The commissioners had control from January 28, I 889, to December 3I, I 894, during a time of industrial depression, and succeeded fairly well in The Railway their attempt to place the railways Commission upon a sound financial basis. They made themselves to a large extent independent of politics, practised unpopular economies, refused demands for concessions on every hand, and made so many enemies that, after six years of struggle, the clamour against them was so great that the commission was abolished. It is the common belief to this day, quite contrary to fact, that their administration was an egregious failure. Their greatest virtues were, in the 
public mind, their most heinous crimes. They were accused of being irresponsible and despotic, of caring only for their salaries, charging exorbitant rates in some cases, and in others competing unfairly with steamship companies, tram-cars and coaches, of opposing reform in administration, and, in general, of being out of touch with the people and disinclined to foster industry and encourage internal development. Another reason that has been given to explain why the commission was abolished is that the Government wanted the patronage which the railways provided.

The proposal to abolish the commission was made an issue in the election of 1893 , and after the return to power of the Seddon Government the Government Railways Act, I894, was passed. It placed the railways in the hands of the Railways Department, now separate from the Public Works Department, and this form of administration has continued until the present time.

The Public Works Department builds the railways; the Railways Department operates them. The Railways Department is doubtless in closer touch with the public than the commissioners were or desired to be. The immediate control is in the hands of the general manager, but the power and responsibility belong to the minister, who is a member of the cabinet and has a seat in Parliament.

Since the year I894-95, only 478 miles of line have been constructed, but much has been done in the way of improving existing lines by strengthening the road-bed; ballasting; building stronger bridges; laying heavier rails; Improvements adding more powerful engines and larger rolling stock, with Westinghouse brakes and other improvements; erecting new station buildings; double- 
tracking certain lines; introducing signals and interlocking systems, together with minor improvements and additions. Most of these improvements have been made with borrowed money, since the net revenues have not been sufficient to pay even interest on the capital cost. The money for such improvements must either be borrowed or paid out of taxes, for the improvements are required to keep pace with the development of the railway business.

The vexed question as to charging "additions to open lines" to capital or to revenue is a question of correct accounting. If the maintenance Additions to account is sufficiently large, so as to Open Lines provide against depreciation, and if the improvements involve real additions to capital value, there can be no doubt that they may be properly charged to capital. It is stated that the Department is particular about this matter, and when, for example, a new station replaces an old one, the cost of replacing the station as it was before is charged to maintenance, while the additional cost of a better building is charged to capital. On the other hand, the entire cost of new rails is charged to revenue. Most of the money, however, is spent for new rolling-stock. As old rolling-stock is discarded, it is written off and replaced out of revenue. A committee appointed by the Auckland Chamber of Commerce to investigate this matter reported as follows:

"We are of opinion that a very substantial amount of such additions should be placed to capital account." (The Herald, Auckland, February I4, I908; H. G. Stockwell, "Depreciation, Renewal and Replacement Accounts," a paper read before the American Association of Public Accountants, October, 1909.)

There was no account of additions to open lines under the commissioners. 
Another argument in favour of charging to capital the cost of improvements is that it is desirable to show in the accounts the exact capital cost of the railways, which would not be done if expenditures beyond a reasonable maintenance were charged to revenue. Had additions to open lines since 1895 been charged to revenue, the capital cost of the open lines would now appear to be something like $£ 23,000,000$ instead of $£ 27,000,000$, and the Department would seem to be earning a higher per cent. of net revenue than it actually earns. In fact, the sum of $£ 27,762,592$, given in the accounts, is not the full cost of the railway system to the people of New

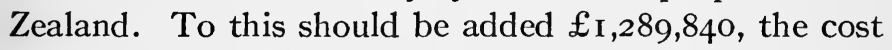
of lines not yet (March 3 I, I909) open, making £29,052,432 as the total capital cost upon which interest should be reckoned.

But the railways have cost even more than this. Since the beginning there has always been a large sum invested in unopened lines, upon which interest has had to be paid, and this must have amounted to several millions

Total Cost of the Railways of pounds in the past thirty-nine years.

There should also be added the yearly deficits, amounting to $£ 4,500$,ooo since $\mathrm{I} 882$, and an unknown sum before that time. If the total capital expenditure were reckoned from 1870 to the present time, it would be seen that New Zealand has actually paid for her railway system not far from $£ 40,000,000(\$ 200,000,000)$. Of this amount only $£ 23,305$,009 was paid out of borrowed money, and forms part of the public debt. The additional cost has been paid from other sources, partly from land sales, but chiefly from taxes, direct and indirect. (Railways Statement, I909; Year-Book, I909, p. 605.)

Since the year I 895 the capital cost has increased 
from $£_{7,703}$ to $£_{10,351}(\$ 50,000)$ per mile of open line, largely because of the improvements High Cost per above mentioned, but also because of Mile of Line the more difficult construction and superior character of the new lines, particularly the recently completed main trunk line. This cost seems high for a narrow gauge road, but it should be remembered that the New Zealand railways, particularly the newer lines, frequently run through a difficult country, where the cost of construction is necessarily high. Also, railway construction is conducted on a small scale, a little at a time, and materials are expensive because of remoteness from the industrial centres of the world. Again, the Department of Public Works assists the Department of Labour in finding work for the unemployed, especially in the winter months, and a large part of the work is done by labourers working in co-operative gangs, generally with pick and shovel instead of modern machinery for excavating and grading. Such facts as these largely explain the high cost of construction. Doubtless another reason is that the work is done by a governmental department and not by private contractors.

Because of the general prosperity of the country, to which, of course, the railways have contributed, the gross earnings of the system have increased from $£_{1,150,-}$ $85 \mathrm{I}$ in $\mathrm{I} 895$ to $£ 2,929,526$ in $1908-09$. But the expenditure has increased in still greater proportion, from $£_{732 \text {,- }}$ I60 in I894-95 to £2,I I4,8 I5 in I908-09, and had it not been for a fall in the rate of interest on Government loans, the deficit for 1909, figured on the basis of the "capital cost" of the open lines, would have been $£_{323,555}$, instead of $£_{212,468}$, as it was.

The Railways Statement, presented annually to Parliament by the minister of railways, does not recog- 
nize the existence of a deficit, but shows a "net profit on working," so called, without noting that it is always insufficient to pay interest on the cost of construc-

Annual Deficits tion at the average rate of interest paid by the Government on the public debt. In the year ending March 3I, I909, the railways earned a " net profit" of 2.93 per cent.

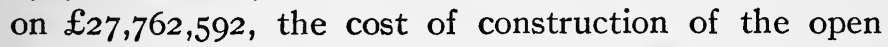
lines, but, since the average rate of interest paid on the public debt was about 3.7 per cent., the "net profit" is absorbed in interest payments, and a deficit emerges, amounting to $£_{2} \mathrm{I} 2,468$ ( $\left.\$ \mathrm{I}, 000,000\right)$, if interest is reckoned on the cost of the open lines only. But the real cost of construction, on which interest should be reckoned, includes the cost of the unopened lines, making a total of $£ 29,052,432$, reducing the "net profit" to 2.80 per cent., and increasing the deficit to $£ 262,760$. This is about the same as the deficits during the administration of the commissioners, but if interest were reckoned at the rate prevailing in their time, the deficit would be much greater. Reckoning interest on the cost of the open lines only, as in the table, the total deficit from 1882 to I 909 is, in round numbers, $£_{4,500,000}(\$ 2 \mathrm{I}, 800,000)$. (Railways Statement, I909, Return No. I6.) ${ }^{1}$

In explanation of the deficit it should be said that some of the lines, chiefly those in the North Island, earn more than 3.7 per cent. upon the capital cost, and that the bulk of the deficit proceeds from losses on the HurunuiBluff section, the main trunk line of

Losses chiefly in the South Island the South Island, I,299 miles in length, of which the net earnings in 1908-09 were only 2.32 per cent. This is the oldest part of the system, being the continuation and linking up of lines begun by the provinces of Canterbury

${ }^{1}$ See table, foot of pp. 74-75. 
and Otago. It is probable that the political influence of the South Island, greater formerly than at present, had much to do with unprofitable railway construction in that part of New Zealand. The Westport section, a coal road 3 I miles in length, is the most profitable of all, earning I 1.85 per cent. on its capital cost but contributing little to the gross earnings of the system. The Nelson and the Picton sections, 48 and 34 miles in length, earn less

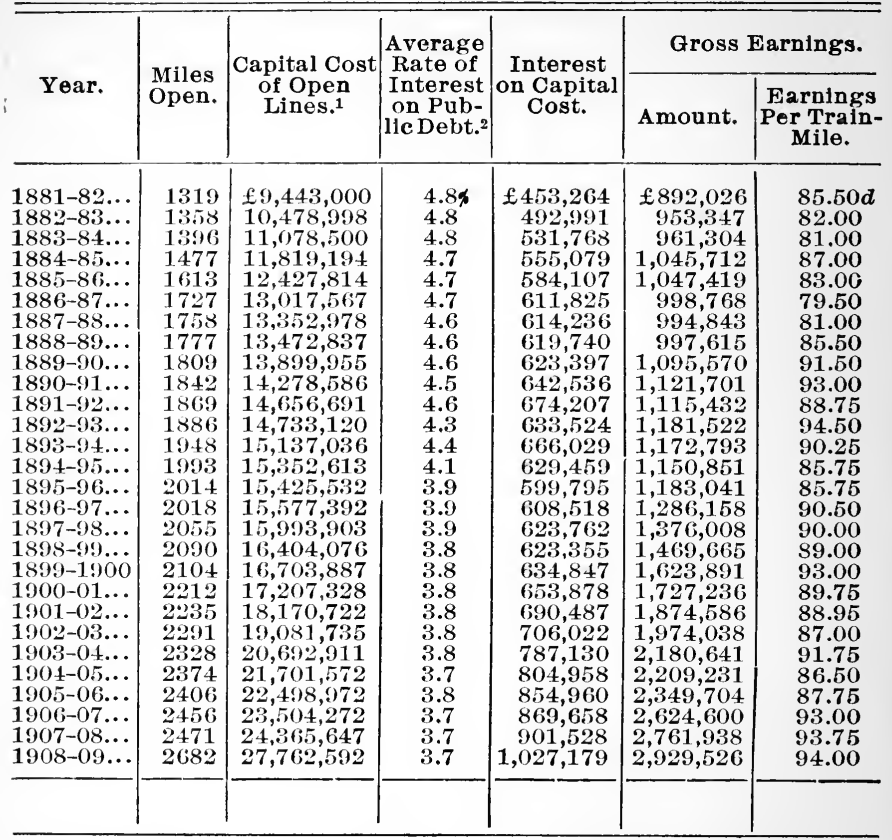

1 If interest were reckoned on the capital cost of open and unopened lines, as it should be, the annual deficits would be much greater than the amount shown in the table. For the year 1908-09 the capital cost of open and unopened lines was $£ 29,052,432$.

2 The average rate of interest on the public debt is less than the rate actually paid on the sums realized by the government from the sale of stock. At the present time 4 per cent. stock is floated at about par, and therefore it would be more correct to take 4 per cent. as the rate of interest on the railway debt. Reckoning interest at 4 per cent. on the cost of open and unopened lines the deficit for 1908-09 would be $£ 347,386$, and 
than one per cent. on the capital cost, while the Kawakawa section, only 8 miles in length, earns less than its running expenses. (Railways Statement, 1909, returns No. 4 and 6.)

Sir Joseph Ward in a recent speech in Parliament, thus explained the losses on the railway system of the South Island:

\begin{tabular}{|c|c|c|c|c|c|c|}
\hline \multirow[b]{2}{*}{ Year. } & \multicolumn{3}{|c|}{ Expenditure. } & \multicolumn{2}{|c|}{$\begin{array}{l}\text { "Net Profits on } \\
\text { Working." }\end{array}$} & \multirow[b]{2}{*}{ Deficit. } \\
\hline & Amount. & $\begin{array}{l}\text { Per } \\
\text { Train- } \\
\text { mile. }\end{array}$ & $\begin{array}{c}\text { Per Cent. } \\
\text { of } \\
\text { Revenue. }\end{array}$ & Amount. & $\begin{array}{l}\text { Per Cent. } \\
\text { of Capi- } \\
\text { tal Cost. }\end{array}$ & \\
\hline $\begin{array}{l}1881-82 \ldots \\
1882-83 \ldots \\
1883-84 \ldots \\
1884-85 \ldots \\
1885-86 \ldots \\
1886-87 \ldots \\
1887-88 \ldots \\
1888-89 \ldots \\
1889-90 \ldots \\
1890-91 \ldots \\
1891-92 \ldots \\
1892-93 \ldots \\
1893-94 \ldots \\
1894-95 \ldots \\
1895-96 \ldots \\
1897-97 \ldots \\
1898-99 \ldots \\
1899-1900 \\
1900-01 \ldots \\
1901-02 \ldots \\
1902-03 \ldots \\
1903-04 \ldots \\
1904-05 \ldots \\
1905-06 \ldots \\
1906-07 \ldots \\
1907-08 \ldots \\
1908-09 \ldots\end{array}$ & $\begin{array}{r}f 523,099 \\
592,821 \\
655,990 \\
690,026 \\
690,340 \\
699,072 \\
687,328 \\
647,045 \\
682,787 \\
700,703 \\
706,517 \\
734,142 \\
735,359 \\
732,160 \\
751,368 \\
789,054 \\
857,191 \\
929,738 \\
1,052,358 \\
1,127,848 \\
1,250,237 \\
1,343,415 \\
1,438,724 \\
1,492,900 \\
1,621,239 \\
1,812,4482 \\
1,949,759 \\
2,114,815\end{array}$ & $\begin{array}{l}50 d \\
51 \\
55 \\
57 \\
54 \\
56 \\
56 \\
55 \\
57 \\
58 \\
56 \\
59 \\
57 \\
55 \\
55 \\
56 \\
56 \\
56 \\
60 \\
59 \\
59 \\
59 \\
60 \\
58 \\
60 \\
64 \\
66 \\
68\end{array}$ & $\begin{array}{l}58 \% \\
62 \\
68 \\
66 \\
66 \\
70 \\
69 \\
65 \\
62 \\
62 \\
63 \\
62 \\
63 \\
66 \\
64 \\
61 \\
62 \\
63 \\
65 \\
65 \\
67 \\
68 \\
66 \\
68 \\
69 \\
69 \\
71 \\
72\end{array}$ & $\begin{array}{r}+368,927 \\
360,526 \\
305,314 \\
355,686 \\
357,079 \\
299,696 \\
307,515 \\
350,570 \\
412,783 \\
420,998 \\
408,915 \\
449,380 \\
437,434 \\
418,691 \\
431,673 \\
497,101 \\
518,817 \\
539,927 \\
571,533 \\
599,383 \\
622,349 \\
630,623 \\
741,917 \\
716,331 \\
728,465 \\
812,118 \\
812,179 \\
814,711\end{array}$ & $\begin{array}{l}3.9 \% \\
3.4 \\
2.7 \\
3.0 \\
2.9 \\
2.3 \\
2.3 \\
2.6 \\
2.9 \\
2.9 \\
2.8 \\
3.0 \\
2.9 \\
2.7 \\
2.8 \\
3.2 \\
3.2 \\
3.2 \\
3.4 \\
3.5 \\
3.4 \\
3.3 \\
3.6 \\
3.3 \\
3.2 \\
3.4 \\
3.3 \\
2.9\end{array}$ & $\begin{array}{r}f 84,337 \\
132,465 \\
226,454 \\
199,393 \\
227,028 \\
312,129 \\
306,721 \\
312,170 \\
210,614 \\
221,538 \\
265,292 \\
184,044 \\
228,595 \\
210,768 \\
168,122 \\
111,417 \\
104,945 \\
84,428 \\
63,314 \\
55,490 \\
66,138 \\
75,399 \\
45,213 \\
86,627 \\
126,495 \\
57,540 \\
89,349 \\
212,468\end{array}$ \\
\hline & & & & & & $£ 4,468,593$ \\
\hline
\end{tabular}

the total deficit since 1881-82 would probably be at least $£ 8,000,000$ and possibly $£ 10,000,000$.

3 The Railways Statement for 1909-10 is not yet available, but the Hon. J. A. Millar, the new Minister of Railways, has stated that the gross revenue for the year was $£ 3,249,790$, the expenditures $£ 2.164,000$, and the "net profit" $£ 1,085,790$, which is 3.78 per cent. upon the capital cost of the open lines. This excellent result has come from a large increase in gross earnings coupled with economy in administration.-Otago Daily Times, May 31, 1910. 


\section{STATE SOCIALISM IN NEW ZEALAND}

"In the South Island the haulage to the ports is over comparatively short distances, and competitive rates are in existence in some places, owing to sea competition. On the Troubles due to Wellington-Napier-New Plymouth Section and Depreciation the Auckland Section the haulage is longer, there is little sea competition, and the lines are newer in comparison with the southern ones. Age brings its troubles to railways as well as to individuals. The pioneer lines have had to be brought up to standard requirements to meet the demands of business by repairs, additions to structures, bridges and station accommodations. As the North Island lines increase in age they will require more expenditure on repairs than at the present moment, and they will then go through the same process that the Southern lines have. . . . The disproportion between the revenue and the expenditure will, as the years go on, become equally as marked in the North Island as the honourable member has said it is now in the South Island." (Parliamentary Debates, vol. I39, p. 664, July 26, 1907.)

If this is true, the financial prospects of the railways are discouraging, since they are not an appreciating asset, as the Department usually claims; and the critics must be largely right in holding that either "additions to open lines " should be charged to revenue, or there should be a large allowance for depreciation, in addition to the allowance for maintenance, which is already high. (The Star, Auckland, February 17, I908.) In I 895 the expenditure on maintenance was $£_{\text {I } 4 \text { I }}$ per mile of line; in 1909 it was $£ 258$, and one would think that this should be sufficient to keep the system in good condition without any allowance for depreciation.

Another explanation of the deficit is given in the Railways Statement for 1909, where the new Minister of

Increased

Expenditure

Railways, the Hon. J. A. Millar, says:

"The enhanced price of materials, increased rates of wages, and expenditure incurred on the works enumerated (track renewals), has had a marked effect on the maintenance expenditure, which has steadily increased during the past ten years. Our railway lines are, however, in a better condition than at any other period during their history."

Still another explanation of the deficit that is given by the Government is that great concessions have been 
given to the public in fares, freights and train services, and to the railway employees in wages and salaries. Speaking, apparently, of the period between 1895 and 1907, Sir Joseph Ward said:

"The concessions given to the public in the matter of fares and freights amounted to $£ 850,000$, and the value of increased train services to $£ 883,000$. . . This takes no account of the consessions in pay given to the railway staff, which amounted to another $£ 375,000$." (The Star, Auckland, February 17, 1908.)

Undoubtedly, wages and salaries have been slighly increased from time to time, to keep pace in a measure with the general increase in wages and cost of living, offset, however, by Wages of Railincreased revenue, due to the general way Servants prosperity of the country. But such increases can hardly be regarded as voluntary " concessions," or gifts, since even now the railway men, if one may believe the Amalgamated Society of Railway Servants, and their organ, the Railway Review, (The New Zealand Railway Review, a journal devoted to the interests of the New Zealand Railway men) are receiving wages rather less than those paid in private employ, while the hours of labour are frequently much higher than would be tolerated in any private business subject to the jurisdiction of the Arbitration Court.

In 1907 there were only thirty-one officials who receive salaries of $£_{400}(\$ 2,000)$ or more. The general manager receives a salary of $£_{I, 250}(\$ 6,200)$, the chief engineer $£ 900$, the chief traffic manager $£ 800$, the chief clerk $£_{500}$. The most highly paid station master, who has been in the service for forty years, receives only $£_{355}(\$ \mathrm{I}, 720)$. Enginemen receive from Ios. $8 d$. (\$2.60) to I2s. (\$3) a day, firemen from $7 s .6 d$. ( $\$$ r.85) to $9 s$. (\$2.25) a day, common labourers generally $7 s$. (\$I.75) a day. (Members of the Railways Department, 1907.) 
Salaries and wages are now slightly higher than they were in 1907, but there is no evidence to show that any material concessions have been made to railway employees. However, they have the special advantages of regular and permanent employment and of retiring allowances under the superannuation system. (Government Railways Act, 1908.)

It is equally difficult to see how it can be claimed that any such sum as $£ 883,000$ has been returned to the public in the form of increased train Concessions in services. The business of the railways Train Services has greatly increased, necessitating an increase in train service, but this can hardly be regarded as a gift, since the public presumably pays for what it thus receives, unless the service is in excess of what the traffic requires. However, unreasonably concessions are constantly demanded by the public, and the Department sometimes gives way, thus sacrificing business principles to political considerations.

There is more ground for the statement that concessions have been made in fares and freights, although Concessions in it seems that the Department has Fares and Freights overestimated the value of these concessions also. In the year I 895 the average charge per ton of freight carried, exclusive of cattle and sheep, was £.333; in 1908 it was £.327. In I895 the average charge per ordinary passenger carried was £.092; in 1908 it was $£ .085$. These figures take no account of considerable reductions in fares for season tickets, designed to develope suburban and tourist traffic, nor of school excursion fares and other minor concessions. But it is a question how far reductions in fares and freights are to be regarded as "concessions," since they appear to 
have been for the most part justified from a business point of view by the increase in traffic which they have helped to develope. In 1895 only $2,048,39$ I tons of freight were carried, exclusive of cattle and sheep; in I $9084,834,534$ tons were carried. In I895 there were $3,905,578$ ordinary passengers; in 1908 there were 9,755,716. (Railways Statement, 1908, returns, Nos. 5 and I6.)

Sir Joseph Ward has frequently said that it would be easy to extinguish the deficit by increasing railway charges, and that, if required, as much as ro per cent. could be earned upon the capital cost. (The Star, Auckland, February 17 , I908.) It is a question, how-

Relation of

Charges to

Net Profits ever, whether the Department is not already, in most places, charging all that the traffic can bear, and whether a reduction in rates would not be more productive of net revenue than an increase. As Sir Joseph himself said, in a recent speech at Carterton:

"If rates were increased, it would mean that the revenue would be reduced, there would be fewer trains, and a number of hands would be dismissed." (The Evening Post, Wellington, November 5 and 12,1908 .)

As to the claim that net profits of ro per cent. could be earned by merely increasing charges, it can hardly have been seriously made. The gross earnings in 1909 were not much more than Io per cent. upon the capital cost of the open lines, and to produce a net revenue of io per cent. it would be necessary to increase the gross revenue, and presumably the fares and freights, by at least 60 per cent., assuming that the traffic and expenditure would remain the same. But such an increase in rates would cause a sharp falling off in traffic, and, instead of producing a larger net revenue, would probably cause the deficit to increase and greatly injure the coun- 
try at large. If the Department could increase the charges in certain districts and lower them in others, according to the amount and character of the traffic, it might be possible to secure a considerable increase in net revenue, but this would be adopting the practice of differential rating, for which the commissioners were execrated, and which would cause a storm of protest and complaint, with charges of favouritism and the like, such as no democratic government could resist.

The chief causes, then, of the railway deficit, appear to be the following:

I. The construction of lines in ad-

Causes of the Deficit vance of requirements.

2. The high cost of all lines.

3. Delays in the construction of lines that might have been profitable, due chiefly to lack of funds.

4. Unprofitable concessions in service, fares, and freights.

5. A rigid system of rates.

6. A high cost of maintenance and operation, partly due to a certain lack of discipline, initiative and efficiency in the railway service. This is disputed, and is hard to prove.

One of the most serious causes of inefficiency and dissatisfaction is the system of promotion. Men are usually promoted merely because their Efficiency of names come first on the list of seniority, Railway Service unless it can be proved that they are actually incapable, which is difficult. The theoretical right to advance capable men over their seniors is practically never exercised, because of the unpleasantness and difficulty of proving alleged unfitness. Until a thoroughgoing system of promotion by merit is 
introduced, there will never be an efficient service. Yet promotion by merit lends itself readily to favouritism and other abuses.

Workers in the Government shops have frequently been accused of practising the "Government stroke." The general manager, Mr. T. Ronayne, recently wrote a strong letter to the The Addington chief mechanical engineer at the Ad- Workshops dington Workshops, making serious charges of inefficiency. However, when the board of enquiry appointed to investigate the charges met at Christchurch on March II, I909, the general manager said that he had been misinformed and that he was perfectly satisfied with the condition of the workshops. Yet in the course of the investigation certain significant facts were brought out, such as the difficulty of getting rid of inefficient men, the difficulty of getting good men when needed, the lack of encouragement to inventors and other good men by promotion and advances in salary, the lack of initiative on the part of the workshops manager, and the lack of up-to-date appliances in certain lines of work. The board of enquiry, the chairman of which was a distinguished engineer, Professor R. J. Scott of Canterbury College, arrived at the conclusion that the cost of production was, generally speaking, greater at Addington than at private and other Government workshops, and the output smaller in proportion to the number of hands employed. Commenting on this report the Evening Post said:

"Here in miniature we have the evils depicted which are rampant more or less in every branch of the Public Service; and if the result is that at Addington we are paying from 30 to 60 or 70 per cent. more for the work done than it would cost us elsewhere, it is natural to infer that the Public Service as a whole is also costing far beyond its value." (The Evening Post, Wellington, June 17, 1909; The Press, Christchurch, June I8, I909.) 
For these and other causes the New Zealand railways have never earned the full amount of interest on the capital cost. But the Government has Three per Cent. frequently declared that it does not Policy wish to make the railways pay. In the Railways Statement for 1905 Sir Joseph

\section{Ward says:}

"The policy of the Government has been throughout to regard the railways as adjuncts to the settlement of the country, and to look upon the earning of a large profit as of minor importance compared with the incalculable benefits that accrue to the State by giving the settlers a convenient and cheap means of transporting the produce of their farms to the markets, and any surpluses which have accrued after the payment of the minimum of 3 per cent. on the capital cost of the lines have been returned to the users of the railways in cheapened freights and increased facilities."

Just why 3 per cent. should be preferred to 3.72 per cent., the average rate of interest now paid upon Government loans, or why it would not be as well to earn only 2 per cent., it is difficult to say. But it is not hard to understand how it came to be thought that the railways should be operated primarily for development rather than for profit.

New Zealand was, and is, a new country, with large undeveloped resources, and the people of every district Development of a New Country

desire roads and railways as a means to one end,-development. To the landowner, development means enhanced prices for land; to the merchant and manufacturer it means an expanding market for their goods; to the labourer it means high wages, steady employment, and opportunity for advancement, particularly while the developmental works are going on. It was inevitable, then, that emphasis should be laid upon development, social service, and all the present and prospective benefits of public works, rather than upon considerations of cost, which would have operated as a check upon public expenditure, 
and might have retarded to some extent the speed of economic development. Besides, it was not necessary to pay cash down; it was possible to borrow, and thus shift the burden of cost upon the shoulders of future generations, which would presumably be well able to bear it. Moreover, it was thought by some, notably Sir Julius Vogel, that the railways would sooner or later pay many times over all the cost of construction and all the losses and deficits of their early years.

Hence the people in every part of the country demanded railways, formed associations for the purpose of securing them, elected members to Parliament pledged to do their utmost to that end; and the Government, unPolitical Railable to resist the pressure of public opinion, borrowed as much as it could, and built short, unprofitable bits of line without counting the cost. The landowners as a class, who were the strongest political force in the colony, were naturally the most eager to have railways built, loudest in their demands for low rates, most intense in their scorn of base commercialism in railway management. The railways might never pay expenses, not to speak of interest on the capital cost, much less contribute to the liquidation of the public debt, but land values would increase, and they themselves would gain in "unearned increments" far more than they would have paid in additional taxation.

The question at bottom is one of social utility versus social cost, and it must be said that, on the whole, New Zealand has gained more than it has lost by the building of railways. But it would have gained more and lost less if the people and the Government had laid

Social Utility in Relation to Social Cost more stress upon the idea of cost, and had in every case 
bent their efforts toward securing a maximum of benefit at a minimum of cost. Social benefit and social cost are vague concepts, hard to measure; but they can be measured with some exactness by means of money, and the financial measuring-rod must be applied to them if the people wish to know whether a governmental undertaking is socially advantageous or not. In the case of the public schools, the cost can be measured, but not the product, for that is non-material, and has no definite market value; and this is the cause, too, of much of the inefficiency that characterizes the school system. But, in the case of the railways, it is quite possible to measure benefit as well as cost, and to strike a balance of profit or loss in terms of money. If this is not done, there is no exact standard of efficiency and no measure of social benefit other than the vague surmise of some one who thinks that a given undertaking was well worth all it cost.

A district that cannot supply enough traffic to make a railway pay, sooner or later, should not have a railway at all; and if, in spite of the prospective

Parasitic loss, the railway is built, it becomes a Railways

parasitic enterprise, drawing sustenance from other industries and other parts of the country, which receive no direct benefit and cannot afford to pay for indirect benefits, since they all have their own burdens to bear. Similarly, it is neither economical nor just to make concessions in rates or service and cause the resulting deficit to fall upon the taxpayers, unless the taxpayers, within a reasonable time, are going to get their money back. If all the users of the railways are taxpayers, it is a matter of indifference to them whether they pay more taxes or higher rates. For the sake of sound finance they should pay higher rates. But, if some taxpayers are not, directly or indirectly, users of the railways, then the policy of gratuitous concessions 
involves making people who do not enjoy the benefits of railway transportation pay for those who do, and who, moreover, are well able to pay for them themselves.

It is said that the country must be developed. ${ }^{\circ}$ But it is neither necessary nor possible to build railways everywhere, and it is possible to spend more The Test of Fairin the development of a district than the ness in Railway district deserves or than the country at Construction, large can afford. Every district claims Service and what it calls its "fair share" of public Charges expenditure, but can allege no sound principle of fairness other than the prospect of developing a large population, large wealth, and a profitable traffic. It is not reasonable to expect a new line to pay from the very first, but longestablished lines ought to pay, and pay enough to recoup the Government for all the losses of earlier years. The idea of making the railways a profitable investment ought ever to be kept in mind as a check upon extravagant expenditure and a guide to further extension. If this is not the test of fairness in railway construction, service and charges, then there is no test other than political influence and the granting of concessions to purchase votes,- - a practice that has done great harm in the past and will greatly retard the future development of the Dominion, unless the Government sternly sets its face against the political control of railways and toward the establishment of sound financial principles in every part of the administration.

Indeed, the financial failure of the railways has been one of the chief causes of the slow growth of railways during the past thirty years. A section of the main trunk line between Auckland and Wellington about 200 miles in length, has taken twenty-three years to build,

\section{Unprofitable Railways retard Development}


although it was the most important link in the whole system, and promised to develop a large and profitable traffic.

"Apart from the fact that this dilatory method of construction has added enormously to the cost, it is appalling to think of the huge sum which the Dominion has paid in interest during construction, to say nothing of the returns which might have been gathered in and the settlement which would have been promoted, had the work been completed with reasonable dispatch." (The Press, Christchurch, September 23, 1908.)

There have been two chief causes of this delay and loss. In the first place, the funds available for railway construction have been distributed, not to say frittered away, in various parts of the country, in the building of small bits of line, instead of being concentrated on one or two important works. This was largely due to political considerations. Secondly, the funds at the disposal of the Government were limited, because the Government could not advantageously borrow more than a certain amount every year, although much larger sums were urgently needed. If the railways already built had been paying investments, earning the full interest on the capital cost, and, perhaps, a surplus to apply to improvements, the considerable sums now borrowed for " additions to open lines" would have been available for new construction, and it would have been easy to borrow all the money needed for projected lines if only they promised, in their turn, to become paying investments. Thus the districts already supplied with railways, by their narrow and selfish policy, have not only compelled the people who had no railways to contribute to the deficit, but have for years prevented these people from getting railways in districts that could be developed and could supply a profitable traffic.

The present Government is aware of these facts; 
and, notwithstanding its own statements to the contrary, which must be regarded as dictated by political expediency, it does Need for Enwish to make tie railways pay. Hitherto lightened Public wish to make tie railways pay. Hitherto Opinion public opinion has not been educated up to the point where it would sustain the Government in trying to apply commercial principles to railway management. But public opinion is changing in this regard. What Dr. Victor Clark says of Australia, "The bad economy of building non-paying lines is now well understood," (Quarterly Journal of Economics; May, 1908), is coming to be true of New Zealand also, and doubtless in the near future the bad economy of non-paying operation, of all sorts of unprofitable concessions, will be equally well understood.

The Government is in a difficult position. Here is an undeveloped district crying for a railway; there a rich and prosperous community is clamouring for concessions of every kind. On Demand for the one hand, the railway servants de- from All Sides mand higher wages and shorter hours; on the other, the Department of Labour asks that railway construction be made subordinate to the provision of work for the unemployed. And yet the financial critics expect the railways to pay interest on the capital cost and earn a surplus for " additions to open lines."

Sir Joseph Ward, in a speech in the House, made a most effective reply to those members who, in one breath, condemn the Government for extravagant expenditure, and, in the next, ask favours of all kinds for their constituencies. He said:

"What is the use of any one indulging in what is nothing more or less than colossal hypocrisy, in urging that the Government should keep down the expenditure of loan money, in proclaiming that we have obtained too much loan money, when every honourable 
member knows that ever since the beginning of the session the Order Paper has been crowded every day with questions asking for new railways, asking for new public buildings, asking for increases in salaries and increases in wages of public employees, asking for concessions in getting some of the public utilities at less than cost price. . . The whole pretence of declaiming against borrowing money and at the same time appealing in other directions for large sums to be expended out of borrowed money is really political hypocrisy." (Parl. Debates, Vol. I39, p. 622, July 24, 1907.)

Notwithstanding the large financial losses of the railways, practically nobody in New Zealand proposes

Private Ownership not Favoured private ownership as a remedy. The railways.could probably be sold for a sum at least equal to their capital cost, and it is probable that a private company could so operate the lines as to pay interest on the cost of purchase, taxes on its property, and moderate but increasing dividends on its stock. From a merely financial point of view it would probably pay to sell the railways to a private syndicate, which, like the railway companies of the United States and Canada, would do much to develop the varied resources of the country. Or, the railways might be leased to a private company, as provided for in the Act, and in this way the Government might have the burden of interest on the railway debt taken off its hands, and receive in addition a considerable rent for the monopoly which the lessee would receive. (An Act to consolidate and amend the Law relating to the Maintenance and Management of Government Railways, I900, Sect. 34.)

But no such proposal would find favour in New Zealand. Sir George Grey once said in the House:

" If we were to sell our railways, we should deal as great a blow at the future prosperity of New Zealand as it would be possible for our greatest enemies to achieve." Even Mr. Vaile is a strong believer in government ownership, and says of his own criticism of the railway administration: "It has been anything but pleasant work for me to write as I have done, for I feel that my exposure of the utter 
failure of the system in this country will be used against me and I fear that an agitation will arise for the sale of our lines." (New Zealand Railway Administration, by S. Vaile. Auckland, 1906.)

It would be highly presumptuous in the present writers to say that New Zealanders are wrong in this regard, for, while the sale of the railways to a private company would probably yield good financial returns, and further rather than retard the development of the country, the creation of a great monopolistic corporation might introduce a source of corruption new to the political life of the Dominion, and for this reason, if for no other, the people of New Zealand may do well rather to bear the ills they have than fly to others that they know not of.

Already there appears to be a strong tendency toward improvement in the railway administration, encouraged by wholesome criticism and suggestion from without. (" Railway Reform," a series of articles in the Evening Post, by A. G. Stephens, January 9, to

Improvement in Railway

Administration March 3, I909.) One of the most interesting suggestions has originated with Mr. Vaile, who has for years devoted much time and thought to railway problems. $\mathrm{Mr}$. Vaile invented the "stage system" of railway rates, in I882, some years before the introduction of the wellknown "zone system " of Hungary. Mr. Vaile's system, however, is the reverse of the Hungarian, which gives better rates to urban than to rural districts, and thus furthers the concentration of population in cities. Mr. Vaile considers that the chief object of railway administration should be to prevent this concentration by distributing population and placing people upon the land. He would accomplish this end by making railway rates in rural districts very low and in urban districts relatively high. The region served by any railway would be divided into stages, short stages in thickly settled dis- 
tricts and long stages in the country, and the fares and freight charges would be the same for any stage, long or short. For example the second-class passenger fare for a stage of six miles, from Auckland to Penrose, would be $4 d$. ( 8 cents, or 1.3 cents per mile), while for the same fare one could travel from Frankton to Te Kuiti, a distance of $4 \mathrm{I}$ miles, making only $\mathrm{I} d$. ( 2 cents) per passenger mile.

The chief effects of this system, as enumerated by $\mathrm{Mr}$. Vaile, would be the distribution of population, the creation of inland trade, a great increase Proposals of in land values, and a large increase in Mr. Vaile railway revenue. It is evident that $\mathrm{Mr}$.

Vaile does not sufficiently consider the limits to the possible development of rural traffic and the financial loss which the Department would suffer if it had to carry a small traffic at such exceedingly low rates. New Zealand has not yet suffered much from congestion of population in great cities, but Mr. Vaile's suggestion as to the distribution of population may yet have to be considered, especially in more highly developed industrial countries, where the growth of enormous cities constitutes a serious menace to the future welfare of the human race. (Railways and Social Conditions, Auckland, I904; Social Problems, Auckland, I 899; The Railway Problem, Auckland, I908; and various other pamphlets by Samuel Vaile.)

Again, it is proposed that the railways be once more placed in the hands of a commission of experts, who, to a

A Railway Commission Proposed large extent independent of political control, may administer the system in a business-like way. The commission that had charge of the railways from 1889 to the end of 1894 has frequently been accused of despotism 
and inefficiency, but in reality its administration compares very favourably with that which preceded it, and the country gained little or nothing by reverting to direct parliamentary control. The general prosperity of New Zealand and of the world, since I894, together with the fall in the rate of interest on New Zealand loans, has largely obscured the bad effects of political management. But they have existed, nevertheless.

The Australian States, notably Victoria and New South Wales, seem to have benefited greatly by the introduction of the commission form of railway administration. A commission is not, and cannot be, wholly removed from that source of demoralization than a Government Department, with a cabinet minister at its head. A commission can be a good deal more independent than a general manager who derives all his power from the minister. The chief objections, real or alleged, to a commission are that it is too independent, perhaps even despotic, not sufficiently in touch with the people and their needs, too conservative in policy, and liable to all the abuses characteristic of governmental bureaus, -abuses which it is very hard to eradicate. (Vaile, "The Future Control of our Railways," Auckland, I893; "Story of New Zealand," chap. 3I.) And yet, the balance of argument seems to be in favour of the commission form of railway administration.

But the prospects of improvement in railway affairs, even under the present form of administration, are somewhat encouraging. After many years of delay the main trunk line of the North Island has been finished; the successful Manawatu line has been purchased; the Government has determined upon a policy of concentration in railway construction and economy in management; and, best of all, there has been a gratifying change of 
opinion with regard to the bad economy of building unprofitable lines and the equally bad economy of making unprofitable concessions at the expense of the taxpayers and those who have waited long for railways that never come.

The new minister of railways, the Hon. J. A. Millar, has definitely abandoned the three per cent. policy, and has repeatedly stated that it is now the The Three per Cent. Policy Abandoned policy of the Government to make the railways earn their own rate of interest. (The Evening Post, Wellington, December II, I909; The Otago Daily Times, May 31, 1910.) In fact, the Government has gone so far as to ask, as a condition of completing the Lawrence-Roxburgh Railway, that the people of the district guarantee at least three per cent. upon the capital cost. (Evening Post, October 19, 1909.) Then, too, the Dominion is rapidly increasing in population and wealth, so that, unless the Government goes into the construction of other unprofitable lines, the deficit should soon disappear, and there should be a surplus to apply, if not to the reduction of the debt, at least to the improvement of the open lines. ${ }^{1}$

It cannot be sound policy for a country like New Zealand, where the Government does so many things, to allow governmental enterprises to be carried on at a loss. Other countries can perhaps afford the luxury of deficits in the postal service and the like, because they merely play at governmental ownership, but to adopt this policy on a large scale would be to start upon the downward path that leads to ruin. Governmental property pays no taxes, and, when there is a deficit, it must fall, sooner or later, upon the taxpayer. Thus, with every

${ }^{1}$ The advanced reports of the railways for the year I909-Io show that, under the economical administration of the Hon. J. A. Millar, there was no deficit, the " net profit" being 3.78 per cent., or slightly more than the average rate of interest on the public debt. 


\section{RAILWAY FINANCE}

extension of governmental activity, taxes would increase, while property subject to taxation would relatively decrease, and the burden would grow until it could no longer be borne. Then it would be clearly seen that the principles of sound private and public finance are essentially the same, and that a profit on public undertakings, the difference between revenue and expenditure, stands for a balance or excess of social utility over social cost. 


\section{CHAPTER VI}

\section{THE PUBLIC DEBT .}

THE most striking fact connected with the financial affairs of New Zealand and the Australasian States is the enormous size of their public debts. Large Public The net public debt of New South Wales Debts

per head of the population is $£_{55}(\$ 267)$; that of Victoria is $£_{42}(\$ 204)$; and the net debt of New Zealand is $£ 67,78 \mathrm{I}, 000(\$ 329,000,000)$, or $£_{70}(\$ 340)$ per head of the European population. (Year-Book, I909, p. 607.) Compared with these figures the debts of most of the other countries of the world are very small. The net debt of the United States, on July I, I907, was only $\$ 878,596,755$ ( $\left.£_{180}, 000,000\right)$, or about $\$$ I $(£ 2)$ per head. If the debt of the United States were relatively as great as that of New Zealand it would amount to about $\$ 30,000,000(£ 6,000,000)$. Canada has a debt of about $\$ 4^{2}(£ 8)$ per head; Great Britain, $\$ 80(£ I 6)$; France, \$I45 (£30). (Statesman's YearBook, I908.)

But a mere comparison of per capita debts of various countries gives a very inadequate idea of the real burden which they have to bear, and is by no means fair to Australia and New Zealand. The debts of European countries have been for the most part incurred in time of war, for necessary but unproductive expenditure, whereas a very large part of the debts of Australia and New Zealand has been contracted for the building of railways and other productive or semi-productive investments. The following analysis of the gross public debt of New 
Zealand, as it stood on March 31, 1909, shows approximately the amounts raised or voted under various heads. (Year-Book, 1909, J. 605.)

(a.) Services -

On 3 Ist March, 1909 .

Railways.

$23,305,000$

Roads, bridges, and lands improvement.

$6,456,000$

Public works and buildings.

$4,983,000$

Immigration $\ldots \ldots \ldots \ldots \ldots$

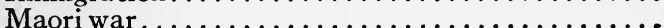

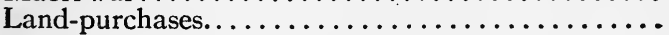

Defence.

$2,446,000$

$2,360,000$

$2,249,000$

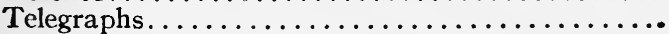

Goldfields and coal-mines.................

$1,955,000$

I, 3 I 7,000

839,000

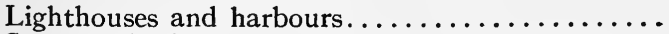

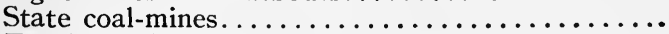

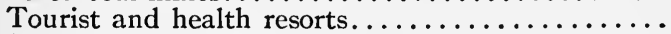

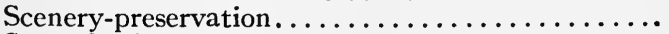

State fire insurance.

557,000

100,000

II 7,000

30,000

2,000

(b.) Investments -

Purchase of land for settlements.............

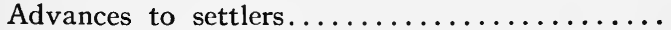

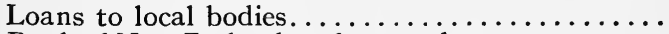

Bank of New Zealand preference shares..........

New Zealand Consols.....................

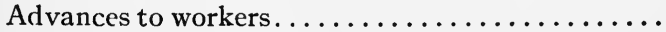

Reserve fund securities...................

$6,101,000$

$5,159,000$

$3,131,000$

500,000

478,000

328,000

800,000

(c.) Other -

Deficiencies in revenue, charges and expenses of raising loans, provincial liabilities, and miscellaneous expenditure...................

Total.

$7,725,500$

$£_{70,938,534}$

Of the gross debt, as shown here, $£$ I6,500,000 represents investments that are directly productive, from which the full amount of interest is recovered, and which, therefore, are no burden on the taxpayers. To this Productive amount may be added the railway debt of $£ 23,305,000$; for, although the railways do not earn the full interest on their capital cost, they do earn the full interest on the railway debt, if we waive the contention 


\section{STATE SOCIALISM IN NEW ZEALAND}

of many critics that there ought to be an allowance for depreciation, or that part, at least, of "additions to open lines" should be charged to revenue. Of the remaining debt, perhaps $£ 2,800,000$ may be regarded as directly productive, since the Post and Telegraph Department earned, in the year 1908-09, a net revenue of $\mathfrak{£}_{106,342}$, which was available for interest payments. (Annual Report of the Post and Telegraph Department, 1909.) To this should further be added the accumulated sinking fund, amounting to $£_{3,156,989}$. There is, then, a total of about $£ 45,000,000$ of directly productive assets, leaving a net debt of about $£ 25,000,000(\$ 125,000,000)$, or $£ 25$ (\$125) per head, the interest on which must be paid out of taxes.

This is still a very large debt, involving an annual expenditure for interest of about $£ 925,000(\$ 4,600,000)$; but much of the money was borrowed

Loans for for roads and bridges and other public Development works, which, although not directly productive of revenue, have greatly furthered the development of the country. Against the net debt, as thus estimated, the Government has a large asset in the crown lands, valued at $£_{21,511,653}$ (YearBook, I909, p. 543), but derives from them no contribution to the annual burden of interest, for the territorial revenue is exceeded by the territorial expenditure. Unfortunately, too, the proceeds of land sales are turned into the Consolidated Fund as ordinary revenue and spent from year to year, although some of the land has been bought from the Maoris with borrowed money. The public domain, then, is a vanishing asset, while the public debt goes on increasing and there is no provision for ultimate payment.

But the greatest asset that a country can have 
is a large and prosperous population, and, since the power to tax is unlimited, it matters little whether the Government has a public domain yielding rent, or a rich territory

Debt and

Prosperity in private hands yielding taxes. Certainly, the net debt is small in comparison with the total private wealth of the Dominion, which in 1906 was

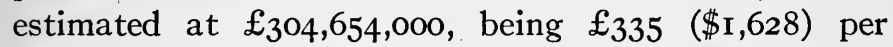
head of the total population-a greater per-capita wealth than that of any other country in the world, although the per-capita wealth of the Northern states of the Union is probably greater than this. Many people in New Zealand, however, both rich and poor, are heavily in debt. On March 31, 1907, the amount of loans secured by mortgage was $£ 59,097,070$. The local governing bodies, too, have a gross debt of $£_{14,223,4 I 7}$, some of which was borrowed from the general Government and forms part of the public debt. (Year-Book, I909, p. I98.) The people of New Zealand, both in their public and their private capacity, are heavy borrowers; but their assets greatly exceed their liabilities, and, unless a period of crisis and liquidation should come, they will have no serious trouble in meeting all their obligations and securing the profits that come to the judicious borrower in a time of rising prices.

In so far as the burden of the debt is concerned, the financial condition is better than it was in 1870 , when Sir Julius Vogel promulgated his celebrated public works policy. At that time the public debt was only about $£ 8,000,000$, but the population wàs only

Financial

Condition

Improving 250,000 and the people were by no means so prosperous as they are to-day. Moreover, there were practically no productive assets, a large part of the debt having been 
incurred for carrying on the Maori war, for roads and for other expenditure not directly productive of revenue. The net debt at that time may be taken at about $£_{32}$ (\$160) per capita, as compared with £25 (\$125) at the present time. Also, the burden of interest was about $£$ I, I2s. (\$8) per capita; now it is about $£_{\mathbf{I}}(\$ 5$.

The Government was in a bad way in 1870 , but the approaching crisis was probably averted or postponed by the daring, not to say reckless, Inflation and policy of Vogel. For the next eight Crisis or nine years the Colony lived on borrowed money. The public debt rose to $£ 24,000,000$; private borrowing was on a still larger scale; and there was a tremendous boom in land values, while the price of wool was slowly falling. Then came the crisis of $\mathbf{I} 879$, the natural result of a period of excessive borrowing and inflation. The Colony did not fully recover from this crisis until about the year 1896 , when a period of prosperity ensued, lasting without interruption until the winter of 1908 .

The next twelve years (I879-I89I) were a period of liquidation, comparative economy, and slow but steady growth and recuperation. Notwith-

Period of Depression standing the depression that prevailed, the population of the colony increased by 36 per cent. In the succeeding twelve years (I89I-I903) it increased by only 30 per cent. During the eight years covered by the administrations of Atkinson and Stout (I883-9I) only about $£ 8$,000,00o was added to the public debt. The effort to live upon income rather than loans was good for the Government and for private citizens as well, and a solid foundation was laid for the extraordinary properity of the time of Seddon. Besides, new resources were developed, particularly the meat- 
freezing industry. The first shipment of frozen mutton was made on February I5, I 882, but it was not until I890 that the value of the meat exported exceeded

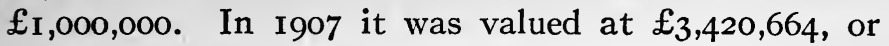
about 17 per cent. of the total value of the exports of the Dominion. Much of the prosperity of recent years has been due to the development of this one industry. The total exports for the year I 890 were valued at

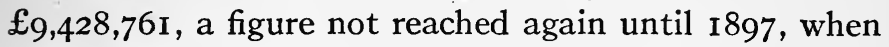
the total exports were valued at $£ 9,596,267$, after which they increased by leaps and bounds, reaching the enor-

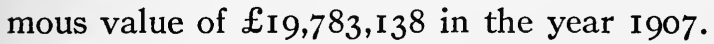

The election of December 5, 1890, the first under a practical manhood suffrage, marks the end of the domination of the large landholders and the rise of a thoroughgoing democracy consisting chiefly of the working class of the towns, the small shopkeepers, and the small

Political Revolution of 1890 farmers.

The leader of the new democracy was the Hon. John Ballance, who became premier January 24, I89I. The premier died on April 27, I893, and on May I was succeeded by the Hon. Richard J. Seddon, who remained in power until his death on June Io, 1906.

Democratic Legislation after 1890 He was succeeded by the Hon. W. Hall-Jones, who remained in office for a few weeks. The present premier, Sir Joseph Ward, took office on August 6, 1906. During this period of democratic rule a large number of Acts were passed for the benefit of the classes in control of the Government. Some of these Acts did not involve any increase in the public debt; others involved the borrowing of large sums. The following table shows the increase of the gross public debt since March 3I, I89I, and the 
chief items of expenditure from loans: (Year-Book, 1909, p. 600.)

Gross public debt, 3 Ist March, 1909................ $\quad \underset{70,938,534}{£}$ “ $\quad 3$ Ist March, I $891 \ldots \ldots \ldots \ldots \ldots \ldots \ldots .38,3,830,350$

Increase....................... $£_{32, \mathbf{1 0 8 , 1} 84}$

Native-land purchases............... $\underset{765,675}{£}$

Land-settlement (including Cheviot)...... 6, IOI,54I

Loans to local bodies................ 2,853,100

Lands improvement................. 500,000

Advances to settlers................ 5, I58,800

Advances to workers.............. $\quad 328,500$

Bank of N. Z. preference shares......... 500,000

N. Z. Consols..................... $\quad 478,573$

District railways................. 47,000

Public works................... I3,438,750

Purchase Wellington-Manawatu Railway.. I, I, 800,000

Increase by conversions and redemptions. . 828,017

Sinking fund accretions............. $1,777,000$

Naval and military settlers............ 27,226

Advances to dairy companies............. I,78I

State fire insurance................ 140,000

Scenery-preservation................. 30,000

Reserve Fund securities. . . . . . . . . . 800,000

Less Redemptions -

Consolidated Stock Act, I884, debentures..................... I, 384,420

Other debentures............ I, 285,359

$2,669,779$

Total net increase ................

While the public debt has increased during this period by an enormous sum, by far the greater part has been

Decreased

Burden of Interest Payment interest on their capital cost. With the development of the country the revenue of the Government has greatly increased and its financial condition has improved. Although the debt per capita has increased, the annual interest payments per capita 
have fallen, because of the fall in the rate of interest. Also, the annual interest payments, which in the year r 89 I-92 absorbed 43 per cent. of the total revenue of the consolidated Fund, in the year 1908-09 absorbed only 24 per cent. of that revenue.

But it should not be forgotten that this improvement has taken place in a time of rising prices of wool, meat, dairy produce, and other exports, and that a policy of borrowing, while usually successful in times of prosperity, may

Dangers of Borrowing become a source of grave danger in the event of crisis and industrial depression. It is quite conceivable that the railways and other investments, which now provide a large part of the interest on their cost, may become less productive and throw a greater burden upon the taxpayers when their ability to pay is materially decreased. The most profitable enterprises in which the Government is engaged do little more than pay their way. They have no considerable margin of profit or surplus which could be used in case of emergency, no buffer to receive the shock of loss, which must fall directly upon the taxpayers or come out of loans which might be hard to negotiate.

The extensive borrowing of recent years has probably caused a good deal of inflation, especially in land values. The unimproved value of land was estimated at $£ 84,401,244$ in 1897 ; in

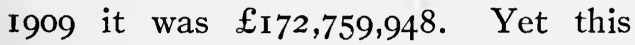
amount is not vastly in excess of

The Government's Credit Good the combined funded debt, public and private, and a marked decline in the prices of the great staples, wool and meat, might cause serious trouble. But the holders of governmental securities are perfectly safe, for they have a prior lien on all the resources of the Dominion. 
The Government, therefore, has little difficulty in borrowing large sums every year at from $3 \frac{1}{2}$ to 4 per cent. A large part of the loans of 1908-09 were issued on debentures at $3 \frac{1}{2}$ per cent. interest, and were floated at about par. Usually, 4 per cent. debentures are floated at a slight premium, and $3 \frac{1}{2}$ per cent. debentures at a discount. (New Zealand Budget, 1909.)

Strong objections are urged against the Government's borrowing in the local market and thus making it harder for people to borrow for ordinary purposes. The Government generally borrows in England; sometimes in Australia; and lends far more than it borrows in New Zealand. There is a good deal of local capital available for giltedged loans at low rates of interest, and it is said that of late years New Zealand capital has been sent abroad for investment, to Queensland and other new fields of enterprise. (The Evening Post, Wellington, October I4, I909.)

Although the public debt is increasing all the time, and must go on increasing, the Government has maintained a sinking fund for many years. The Sinking In I909 it amounted to $£_{3,156,989}$, and Fund was mostly invested in New Zealand securities of various kinds. The advisability of maintaining such a fund has often been questioned. Mr. William Fraser said in the House:

"I do not think there is any use whatever in a Colony which is continuing to borrow to pretend to build up a sinking fund when we know perfectly well that, directly or indirectly, the money we are setting apart is derived from borrowed money." (Parliamentary Debates, Vol. I39, p. 578.)

But Mr. Massey, the leader of the opposition, defends the sinking fund:

"In order to show our creditors that we intend to meet our obligations at the due date there should be something in the way of a sinking fund." (Ibid, p. 546.) 
The sinking fund, too, has been found useful in the raising of loans, especially when it could be temporarily hypothecated as a sort of collateral security. (Parliamentary Debates, Vol. I40, p. 130.) It is like a substantial balance in the bank, useful for many purposes, though not intended, as its name might imply, to secure the ultimate payment of the public debt. It has not always been used for legitimate purposes, but latterly its integrity has been respected; it has been greatly augmented, both from loans and revenue; and now forms an important part of the financial system. In a recent speech Sir Joseph Ward said that he would soon propose a comprehensive scheme for the liquidation of the entire debt at the end of 75 years. (Speech of Sir Joseph Ward at Winton, May 5, I910.)

Meanwhile the public debt is increasing from year to year. The increase for the year I 908-09 was $£ 4,484,637$. Speaking of the increase in the public debt since the Liberal Party came into power, Sir Joseph Ward says:

The Public

Debt Increasing

"The whole of the increase in the public debt has been used in directly reproductive objects, producing a profit in addition, and the expenditure on unreproductive objects, such as roads, bridges, mines, public buildings, tourist, health, etc., have been provided out of revenue." (Budget, 1909, p. 2.)

While this may be a somewhat optimistic statement, in view of the fact that the railway deficit for I908-09 was $£_{212,000 \text {, and the net profits on advances }}$ to settlers and other governmental Earning Power enterprises, according to the Govern of Government enterprises, according to the Govern- Investments ment's own showing, were less than

$£ 200,000$, it is certain that the increase in the public debt since $I 89 \mathrm{I}$ is represented by assets which earn or might earn the full interest on their capital cost, and could be sold, if necessary, for a sum large enough to pay the 


\section{IO4 STATE SOCIALISM IN NEW ZEALAND}

full amount of the new debt. It should be noted that the total sum invested in these enterprises, including the railways, is greater than the amount of the debt incurred, for contributions have been made from the general revenue through the Public Works Fund, and deficits also have been made up out of revenue, so that it is difficult, if not impossible to discover the real capital cost. The governmental enterprises, taken as a whole, have not earned anything like the full interest on their capital cost, but do now earn very nearly the full interest on the debt incurred in establishing them, and should earn much more than this in the near future, if the financial administration of the Government can be divorced from politics.

The Public Works Fund is derived chiefly from loans, but partly from taxation, since a large sum is transferred every year from the Consolidated Fund.

The Public Works Fund In the year 1908-09, the Public Works Fund received $£ 800,000$ from this source, and from I891 to I909, the sum of $£_{7,230,000}$ was thus transferred, which was expended chiefly on roads and public buildings but partly in the creation of productive assets. In the financial year, ending March 31, 1909, the sum of $£_{3,363,895}$ was spent out of the Public Works Fund, and the expenditure was distributed as follows:

(Public Works Statement, I909, p. 2.)

Expenditure on Services: -

Public Works Fund -

Railway construction and improvement

Purchase Wellington-Manawatu Rail-

Roads. way $\ldots \ldots \ldots \ldots \ldots \ldots \ldots$.

Public buildings......................

Telegraph-extension...................

Lighthouses, harbour-works, and har-

$$
\begin{array}{cc}
\mathfrak{f} & £ \\
\mathbf{I}, 356,996 & \\
& \\
933,759 & \\
469,548 & \\
285,521 & \\
163,033 &
\end{array}
$$
bour-defences................ 
Immigration $\ldots \ldots \ldots \ldots \ldots \ldots \ldots \ldots \quad \stackrel{\mathbf{1} 5,077}{\stackrel{E}{2}}$

Tourist and health resorts.......... 24,285

Development of goldfields.......... 32,859

Contingent defence............ I0,766

Lands improvement............ I9,542

Purchase of Native lands.......... $\quad 2,099$

Rates on Native lands ........... 27

Public Works departmental expenses... 24,512

Charges and expenses of raising loans.. $\quad 6,654$

$\underline{3,363,895}$

Carried forward.................. 3,363,895

In this table it can readily be seen that the total expenditure for roads, public buildings and other unproductive services considerably exceed the contribution of $£ 800,000$ from the Consolidated Fund. But the year 1908-09 was exceptional, for the Government does not usually borrow for unproductive expenditure, unless part of the money spent in improving open lines of railway may be regarded as unproductive. However, if the cost of roads, public buildings, and the like, were charged directly to revenue, instead of being first transferred to the Public Works Fund, there would be little or no surplus, and the Government, for obvious reasons, prefers to show a surplus. (Public Works Statement, I909, Tables I-8.)

Members of the opposition and other critics of the Government take pleasure in scoffing at the surplus, and with reason. In the debate on the Budget for 1908, Mr. Fisher said: The Surplus "It is extraordinary that the country should borrow $£_{1,000,000}$ and end the year with a surplus of $£_{700,000 . "}$ Mr. James Allen is reported as saying:

"The Public Works Fund was called upon to find money for services that in previous years had been charged, and rightly charged, 
to the Consolidated Fund . . - the object having no doubt been to make it appear that there was a larger surplus than really existed." (Evening Post, July 13, 1907.)

Mr. Laurenson is reported to have said in the same interview:

"To a very large extent I agree with the writer [Nemesis] that there should be a more strict allocation of borrowed money in the direction of investment in reproductive works, and in reproductive works only. During a period of high national prosperity such as we are passing through at present, I believe the Government would be justified in raising more money by way of taxation and less by way of loans, because one cannot help having an uneasy feeling that if bad times strike us we shall then not only be short of money ourselves, but, having taken full advantage of the money market during times of prosperity, we shall be unable to approach it successfully in the day of adversity." (Evening Post, July I3, I907.)

Mr. Massey, the leader of the opposition, said in the House:

Questionable

Charge to

Capital Account

"These charges simply cannot be defended. Why are they so charged? Simply to enable the Government to show a huge surplus at the end of the year." (Parliamentary Debates, Vol. I39, p. 553, July 23, 1907.)

The writer of a series of articles in the Evening Post says:

"In business, charges such as these would only be charged to capital by weak and struggling concerns existing on a bolstered balance sheet." (Evening Post, October 6, 1909; article by " Nemesis.")

A more conservative writer makes the following statement:

"It would no doubt be better, and the Government would be on firmer ground, if revenue did not make quite so large a contribution to the Public Works Fund, and if, instead of doing that, it had charged upon it all items of a doubtful character, such as public buildings for ordinary governmental and not for revenue-producing purposes. In Australia new buildings, such as courthouses, police stations, hospitals, and schools, are charged to revenue, and New South Wales similarly treats the cost of post-offices." (Evening Post, July 10, I907, article by " Senex et Juvenis.")

Most of the financial critics appear to ignore the fact 
that the Public Works Fund usually derives more from revenue than is spent in an unproductive way, and that the Government now spends all the money it borrows, and

A Question of Accounting more besides, on productive works. The question is largely one of correct accounting, and there can be little doubt that there is room for reform in this regard. The discussion is well summed up by $\mathrm{Mr}$. J. C. Thomson, who says:

"Even supposing that this reform is only a matter of bookkeeping, it would be far better to charge all the current expenditure to the consolidated revenue, and although the surplus might be smaller, at the same time it would be putting the correct position before the country. It is better to know one's true position than to live in a fool's paradise." (Parliamentary Debates, Vol. I39, p. 604, July 24, 1907.)

The severe and sometimes unjust criticism to which the Government has been subjected has had a good effect, and reforms in the system of accounting are likely to be introduced which will result in economies in expenditure and will present to the people, or, at least, to those who take an interest in such matters, clear statements of the finances of every department, so that there may be no question as to the financial success or failure of the important enterprises undertaken by the Government. (Budget, 1909, p. 16.)

But whether derived from revenue or from loans, or whether expended for productive or unproductive purposes, an enormous sum is spent every year out of the Public Works Fund, and the question as to the proper distribution of this expenditure is of the

Distribution of the Public Works Fund greatest concern to the people of the Dominion. During the year 1908-09 the disbursements totalled $£_{3,363,895}$ $(\$ 16,300,000)$ (Public Works Statement, I909, p. 2), apportioned as shown above. Presumably, the distribution is made according to "needs," but the concept of 
" needs" is very vague and most elastic. The Government itself hardly knows what the Dominion needs in the way of developmental expenditure. In the case of roads and bridges, the greatest need appears to exist in the thinly settled back blocks, where it would not be difficult to expend on roads more than the improved land is likely to be worth for years to come. In the case of districts already developed it is not easy to distinguish between needs and wants.

But the members of Parliament from every part of the Dominion come to Wellington prepared to enlighten the Government as to the needs of their constituents, and the chief work of the Political Works members - that, at least which, best secures their re-election - seems to be the getting of appropriations of one kind and another from the Public Works Fund. Every part of the Dominion clamours for its "fair" share of expenditure, and to some extent the apportionment is made proportional to the political influence of the various electoral districts. Petitions for public works of every kind are showered upon the minister, demanding in the aggregate far more than the available funds. Most of the requests, therefore, must be denied, but the Government does its best to be "fair" to everybody without making too many enemies, and without running the country into bankruptcy, and the temptation to augment the Fund by further borrowing is almost irresistible.

In the time of Seddon the Public Works Fund was a veritable corruption fund and was confessedly used for

A Corruption Fund instruments that maintained him in office for his
record period was the clever manipulation of this Fund. (Evening Post, July 5, 1907.)

political purposes. "Nemesis" says:

"Proud as we are of our great statesman there is little doubt that one of the most poterit (Evening 


\section{THE PUBLIC DEBT}

Mr. Seddon himself said in Parliament:

"I am not one of those who say that, other things being equal I should not favour the district that was represented by one who helped to maintain the Government in power."

At another time he said:

"It is unreasonable and unnatural to expect the Government to look with the same kindly eye on districts returning members opposed to the Government as on those which returned Government supporters." (Reformer, Christchurch, No. 2, October, 1905.)

The older settlements, like certain parts of the South Island, were naturally served first; while the newer parts had their turn later; when the older districts began to develop a taste for economy in expenditure and restric-

Economy Demanded tion of borrowing. But Mr. Seddon was not prepared to adopt this policy, and said in Parliament, with even more than his usual frankness:

"I say that until we have had a fair expenditure of public money out of loans upon each part of the Colony, it is wrong of those parts that have had a fair share to say suddenly that there is to be no more borrowing." (Parliamentary Debates, Vol. 99, p. 29I.)

The Ward Government, especially during the past few years, has taken a stronger stand than this. Sir Joseph Ward said in the House:

"Members had only to look at the order paper for this session and what did they find? They would find that there had been a universal demand from all sides of the House for far more money than the country could possibly provide. The Government, if they did not resist this extraordinary demand, would not be fit to hold their positions on the treasury benches." (Parliamentary Debates, Vol. 140, p. 248, August 15, 1907.)

And yet, in the Budget for 1908, notwithstanding the hard times, Sir Joseph Ward proposed for the ensuing year an expenditure of $£ 2,350$,ooo out of the Public Works Fund. He said:

Pre-election

Promises

Fulfilled

"Hon. gentlemen will see that an effort has been made to do even-handed justice to all classes of the Dominion, and I trust that 
by the means which I have outlined every section of the country will be brought into closer harmony for the one great purpose - namely; the promotion of our national well-being and happiness." (Budget, I908, p. 21.)

During the year I908-o9, $£_{3,363,895}$ was spent out of the Public Works Fund, including $£ 933,759$ for the purchase of the Manawatu Railway.

The appropriations were unusually large because of the approaching election of November, 1908, in which the Ward Government was returned to power, but with a reduced majority. In criticism of the Public Works statement, The Press very pertinently says:

"One of the most regrettable results of the Expenditure for system under which the general Government catching Votes borrows money to carry on public works is that the amount of borrowing and the manner in which the money is allocated, are determined by the exigencies of the political situation, rather than by the dictates of economic prudence. The Public Works statement delivered by Hon. W. HallJones last evening was a business-like document, but the trail of the general election is over it all. . . . The reckless manner in which we now rely on ever-increasing loans is all the more regrettable when it is borne in mind that a good deal of money is frittered away in political works, with the object of catching votes, while a considerable proportion is expended in so-called "additions to open lines," and other items which really ought to be provided for out of revenue. The taxpayers are again to be bribed with their own money." (The Press, Christchurch, September 23, 1908.)

In a similar vein the Evening Post says:

"Under the present system roads and bridges must continue to be the current coin of political corruption, and there is not the faintest indication that the ministers have any intention of laying the axe at the root of this unlovely growth." (Evening Post, September 23, 1908.)

The most common form of political corruption in the United States, the corrupting influence of railways and other business corporations, does not exist to any great extent in New Zealand, because of the prevalence of governmental and municipal ownership, and because of the superiority of the judicial and administrative systems; but the concentration of a large part of the economic power of the community in the hands of the Gov- 
ernment has created a form of corruption which, while its moral evils may not be so far reaching, is far more wasteful from the economic point of view. That this form of political corruption is not more prevalent in the United States is not due to any special virtue on the part of American politicians, but solely to the fact that the Government has relatively fewer functions to perform and less money to spend, and no one can doubt that it would flourish on American soil even more luxuriantly than in New Zealand, where it is held in check by the cabinet system, under which the budget is in the hands of a responsible ministry, and not, as in the United States, in the hands of relatively irresponsible committees.

The following quotation from a speech of Senator Francis E. Warren, of Wyoming, might have been uttered by almost any The Statesmanmember of Parliament from the back ship of "Getting country of New Zealand:

"The position of a servant of the people in Congress is peculiar. His environment and surroundings in Washington form a constant temptation to him to become a statesman, so called, and indulge in large theoretical questions of Government rather than engage in the real work of constructive legislation, such as getting appropriations and various favours for his own State, pensions for its old soldiers, and the thousand and one little things his constituents desire. From the older eastern and middle States, where the local wants have long since been supplied, a member of the House or Senate can indulge himself and safely devote his time to oratory and statesmanship with glory to himself and without damage to his constituency. But the man from a young, virile, exacting western State, with pressing local needs, must spend his days, nights, and Sundays in hard, continuous, grinding work for his people, if he expects to win, doing the less glorious but more satisfactory duty of getting things." (Denver Republican, June 26, 1908.)

There can be no doubt that the Government of New Zealand has done much to foster the industries of the Dominion, and that economic development has been greatly stimulated by Extravagance expenditure of vast sums of borrowed in Expenditure money; but it seems probable that too 
much has been borrowed and that there has been a good deal of misdirection and waste in expenditure. The ease with which the Government has been able to borrow has been a temptation to extravagance which it has been unable to resist. The Bulletin says:

"The Dominion has been enjoying a fictitious prosperity; land and property values have been artificial; nearly everything has been artificial." (Bulletin, Sydney, N. S. W., May 28, I908.)

Perhaps this is an extreme statement, for The Bulletin makes a special effort to check the Australian states and New Zealand in their career of borrowing, but the Dominion has certainly been living quite largely on borrowed money, has been very optimistic with regard to the future, and much inclined to shift the burden of development to shoulders of posterity. True, posterity may be well able to bear the burden, especially since a large part of the interest, if not the whole of it, will be provided by the various enterprises in which the Government is engaged, but it is possible that the earning power of these enterprises, at no time great, may be reduced; that the prices of wool, mutton, and dairy produce may fall, and that it may be increasingly difficult for the Government to effect loans. If any or all of these possibilities are realized, the position of the Government will be unfortunate, for it is sailing very close to the wind, carrying much sail and little ballast, counting on fair weather and not well prepared for storms.

However, the Government seems to have successfully weathered the crisis which began in the winter of

The Crisis of 1908-9

Igo8 and continued through the winter of I909. Although the exports fell from $£_{19,783,530}$ in 1907 to $£_{I_{5}, 894,530}$ in I908, the value of the imports increased from $£$ I6,539,707 to $£_{\mathrm{I} 7,247, \mathrm{I} 62 \text {, and the revenue from customs duties was }}$ 
well maintained, notwithstanding considerable reductions in duties granted by the tariff Act of 1907. The land and income taxes were more productive in 1908-09 than in 1907-08, also the beer duty and income from stamps, so that there was only a slight falling off in revenue. On the other hand, the expenditure from the Consolidated Fund increased by over $£_{500,000}(\$ 2,000$,ooo), so that the surplus of $£ 767,849$ of the previous year was reduced to $£_{1} 84,32$ I on March 3I, I909. Although the Government advanced to settlers and workers a larger sum than ever before, it could not supply the demand for loans, and loans from private lenders were hard to obtain.

It is probable that the crisis would have been far more serious had the Government not been able to borrow large sums on favourable terms for loans to settlers and workers and for keeping Disaster averted up even more than the usual expenditure by Further on public works. Sir Joseph Ward says, in the Budget of 1909 :

"It is difficult to conceive what would have been the state of things during the past twelve months if the Advances to Settlers Department had not been in existence."

Disaster seems to have been averted by further borrowing, and one is strongly reminded of the financial situation in the early seventies, when the approaching crisis was postponed by the extensive borrowing and expenditure inaugurated by Vogel.

But the general financial outlook seems to be better than it was in the time of Vogel. The buoyancy of the wool market has carried the Dominion well out of danger and there are good optimism of prospects of rising prices of mutton and the Government dairy produce for some time to come. Then, too, private wealth is increasing as the country 
developes. In the Budget of 1909 , Sir Joseph Ward makes an extraordinary estimate of private wealth, claiming that it is equal to $£_{768}(\$ 3,700)$ per head of the mean population. While this estimate is much exaggerated, being at variance with all previous calculations, there can be no doubt that the private wealth of the Dominion is far greater than the amount of the public debt, and that the danger of bankruptcy, which some have predicted, is very remote indeed. Sir Joseph Ward rises to a veritable paean of triumph when he says:

"These figures and facts prove that although the public debt has. increased by the amount I have stated, the assets in the rapid development of the country have increased in a vastly greater ratio: for every $£_{1}, 000,000$ increase in the public debt the assets have increased by fully $£_{10}, 000,000$. This in commercial circles would be considered very sound business." (Budget, 1909, p. 3.)

And yet, the financial stress through which the Dominion has passed has taught the wisdom of caution Retrenchment in borrowing and economy in expenditure. Sir Joseph Ward himself says:

"I do not think it wise for this country to continue borrowing annually for public works to the extent that it has been doing." (Budget, 1909, p. 3I.)

In the winter of 1909 the Government inaugurated a scheme of retrenchment in the civil service which, Sir Joseph Ward said, "will effect a total saving exceeding a quarter of a million sterling, and this without impairing the efficiency or inconveniencing the public in any way." (The Press, Christchurch, April 3, i909.)

This retrenchment has been partly carried out, resulting in a saving of $£ 98,970$ and affecting some 940 civil servants at a time when it was a very serious matter for them to lose their billets. But a serious fall in the revenue from customs duties during the first part of the year made some degree of retrenchment absolutely necessary. Early in the year I9Io Sir Joseph Ward 
announced that the return of good times had removed the necessity for further retrenchment.

(Otago Daily Times, May 6, 1910.)

Meanwhile, because of the alarm in Great Britain about a possible German invasion, New Zealand has offered to provide a "Dreadnought" for the British navy, at a cost of about $£_{2,000,000}(\$ 10,000,000)$, which will Dreadnoughts necessitate further loans, and, probably, more retrenchment. (Budget, I909, p. xii.) This will involve an expenditure decidedly unproductive in its character, but approved by the people of New Zealand, who fear the colonial ambitions of Germany, strongly believe in the "yellow peril," and are most loyal to the British Empire. In view of the need for more "Dreadnoughts" in the future it seems desirable that strict economy be practised and that the credit of the Government should stand as high as possible.

When Parliament met toward the end of the year, it provided for additional taxation to meet an anticipated decline in the revenue from customs duties and from the income-tax. Altogether, the finances cannot be said to be the Taxpayers in a perfectly satisfactory condition. If there is to be less borrowing in the future there must be more taxation, and very soon it will be necessary to impose direct taxes upon the small proprietors who have ruled the Dominion for the past nineteen years. When this takes place there will doubtless be a marked change of opinion in the direction of economy in expenditure and financial reform in general.

Already there has been much criticism of the financial policy of the Government, and many valuable suggestions have been made, among which the following appear most deserving of mention: 
I. As far as possible, the Government should borrow only for works that are directly repro-

Government's Credit must be Maintained ductive, yielding at least interest on their capital cost.

2. The railways and all the other investments of the Government should earn the full amount of interest on their capital cost, and a surplus besides, to cover any possible depreciation or any deficiency of revenue in time of crisis.

3. Roads and bridges should be paid for out of revenue, and at least half of the cost should be paid by the locality benefited, preferably by a betterment tax on land values.

4. Maintenance of roads and public buildings should be charged to revenue, but the local governing bodies should bear the greater part of the expense of keeping up the roads.

5. The part of the debt not represented by productive investments should be paid off gradually, whether by means of sinking funds or otherwise. The proceeds from the sale of public lands should be set apart for this purpose.

6. There should be greater uniformity in the accounts of the various departments, greater publicity of accounts, and a system of post-audit instead of pre-audit as formerly.

To effect any or all of these reforms it is desirable and necessary that criticism of public affairs should be encouraged and an effective public opinion created that will support the Government in maintaining sound principles of public finance. Unless the people can be enlightened, and persuaded to prefer the general welfare to sectional interests, the only hope of reform lies in the unpleasant prospect of financial stringency which will compel economy by cutting off the supply of funds. 


\section{CHAPTER VII}

\section{THE LAND AND INCOME TAX}

The New Zealand Government is different from both the Federal and the State Governments of the United States in that the power to levy taxes of all kinds in practically unrestricted. Theoretically, the British GovAutonomy of ernment, in the exercise of its supreme New Zealand legislative authority, has the right to tax all parts of the Empire, but the right is never exercised. The principle established by the American Revolution, that there shall be no taxation without representation, still bears fruit in the practical autonomy that New Zealand and the other self-governing dependencies enjoy.

The New Zealand Government is not hampered by any constitutional restrictions as to the purpose for which taxes may be levied, nor is there any prohibition of class legislation nor any clause in the Constitution Act forbidding the taking of private property without due process of law, although as a matter of fact this is never done. The Government has a free hand. It may and does levy duties on imports from Great Britain and other parts of the Empire; it imposes taxes not only for revenue but as a means to social reform; and many of its laws, as the graduated land tax, would doubtless be regarded as class legislation by American courts.

The following are the chief heads of revenue and expenditure for the year I908-09 of the Consolidated Fund, which

The Consolidated Fund includes the revenue and expenditure of the Post and 


\section{II8 STATE SOCIALISM IN NEW ZEALAND}

Telegraph Department and the Railways Department, but not that of the other governmental enterprises, for which there are separate accounts. (Year-Book, I909, p. 575.)

\section{CONSOLIDATED FUND REVENUE AND EXPENDITURE}

\section{Revenue.}

Balance on 3 I st March, I908.

Customs duties.

Beer duty

Stamps (including postal and telegraph cash receipts)

Land-tax...

Income-tax

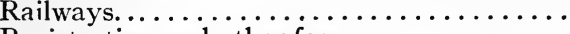

Registration and other fees.............

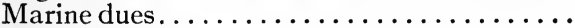

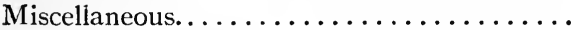

Territorial revenue................

Other receipts -

Recoveries in respect of expenditure of previous years.

\section{Expenditure.}

His Excellency the Governor. . . . . . . . . . . Legislative...................... Ministers' salaries and allowances.......... Interest and sinking fund charges.......... Exchange and commission.............. Pensions, civil and military.............

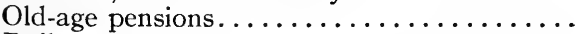

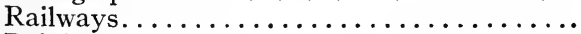

Public instruction..................

Postal and telegraph services............

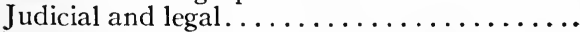
Hospitals and charitable institutions....... Defence (including Naval) ............. Subsidies to local bodies............... Department of Agriculture................ Mental hospitals.

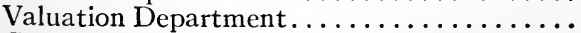

Customs.

Marine (including harbours and lights)..... Printing and stationery................ Electoral.

Registration of land and deeds, births, deaths,

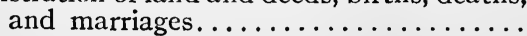

$£$

$2,801,248$

II 6,2 I 4

I, 591,328

604,901

321,044

$2,918,507$

I 17,061

43,8 I 5

264,210

222,857 $\stackrel{f}{f}$

$9,001,185$

$£_{9,769,834}$

$$
\begin{array}{r}
£ \\
7,000 \\
61,409 \\
16,882 \\
2,258,365 \\
20,091 \\
40,616 \\
345,630 \\
2,120,987 \\
874,818 \\
806,293 \\
366,456 \\
157,931 \\
233,976 \\
115,704 \\
168,422 \\
90,482 \\
35,451 \\
52,309 \\
67,692 \\
46,964 \\
66,454
\end{array}
$$


Public buildings and domains, and maintenance of roads...................

Public Health Department...............

Labour Department..................

Tourist Department..................

Contribution Superannuation Funds........

Miscellaneous expenditure..............

Territorial expenditure................

Other expenditure -

Transferred to Public Works Fund......... Balance on 3 Ist March, 1909.

87,185

38,025

30,57 I

50,771

27,000

$2 \mathrm{II}, 003$

354,330

$8,785,5^{1} 3$

800,000

I 84,32 I

$£ 9,769,834$

Of the total revenue, as shown here, less than one half was derived from taxation, and the amounts raised were as follows : (Year-Book, 1909, p. 594.)

Customs and Excise Duties.................. £2,91 7,462

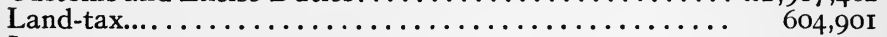

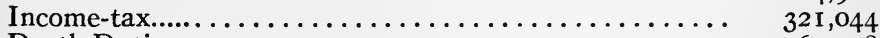

Death Duties.......................... 260,238

Other Taxes......................... 274, I1 6

Total..................... $£_{4,377,761}$

If to this amount we add $£_{\mathrm{I}, 466,598}$, the total of local taxation, including special taxes for water and other utilities supplied by some municipalities, we have the sum of $£_{5}, 844,359$ paid by the people of New Zealand in Taxation per Capita general and local taxes (Year-Book, r9o9, p. 597). This gives an average of about $£_{5.8}(\$ 28)$ per head of the total population, including the Maoris, an average considerably higher than the total of federal, State and local taxation in the United States, which was about $£_{3.3}(\$ 16)$ in the year 1902 and cannot be more than $£_{4.3}(\$ 20)$ at the present time. However, the per capita taxation in the richer States of the Union is greater than this. (Special Report of the Census Office on Wealth, Debt, and Taxation. Washington, I907.) 
The revenue from taxation in New Zealand has greatly increased in recent years. In I897-98 the general and local taxes were only $£_{4.4}(\$ 2 \mathrm{I} .38)$ per head of the total population. This extraordinary increase in per capita taxation has not been due to any increase in the rate of taxation, but to the great prosperity of the Dominion during the past ten or twelve years, most of the taxes being elastic, automatically increasing their yield in good times.

More than half of the revenue from taxes is derived from customs duties. This is due to the enormous foreign commerce of New Zealand, whose prosperity depends chiefly on the export of Customs vast quantities of wool and frozen mutton, also dairy produce, in return for which the Dominion imports largely from abroad, chiefly from Great Britain and other parts of the Empire. In the year 1908 the value of the imports from foreign countries was only $£ 2,69 \mathrm{I}, 008$ out of a total value of

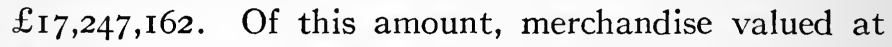
$£_{\mathrm{I}, 643,937}$ was imported from the United States. The value of the total imports for 1908 was equal to about $£_{17.2}(\$ 83)$ per head of the total population, compared with which the import trade of the United States is very small, being only $£_{3.5}$ (\$I 7 ) per head in the year 1906-07. On the other hand, the domestic commerce of the United States is relatively far more important than that of New Zealand.

An interesting feature of the New Zealand customs duties is the preferential tariff in favour of British goods, established by the Seddon Government The Preferential in 1903. This did not involve a reducTariff tion of the duties on British goods, but an increase in the duties on goods imported from foreign countries. At first these extra duties 
were imposed on 37 classes of goods of foreign manufacture, but now about 198 items are included. In spite of the preferential tariff, which is intended to encourage trade with Great Britain, and the British Colonies, as well as to give the New Zealand manufacturer additional protection, the imports from the United States in 1908 showed a substantial increase over those of the previous year.

The New Zealand tariff is not highly protective, and yet it is something more than a revenue tariff. The duties of the ordinary tariff range from

5 per cent. to 40 per cent.; those of the Indirect Taxes preferential or discriminatory tariff run Predominate as high as 50 per cent. or more, as in the case of the cheaper grades of American-made shoes. The revenue derived from customs in the year 1908-09 was about I 7 per cent. of the value of the imports and about $£ 2.9$ (\$I4) per head of the total population. In the year 1906-07 the customs revenue of the United States was about 23 per cent. of the value of the imports and only about $£ .8(\$ 4)$ per head. In the United States, therefore, a larger proportion of the revenue, in fact, almost the whole of the revenue of states, counties, and other civil divisions, is derived from direct taxation. Only the large volume of imports makes it possible for the New Zealand Government to derive so large a proportion of its income from customs duties. As the country developes it will doubtless be necessary to raise an increasing proportion of the revenue by means of direct taxation.

The Land and Income tax, although yielding little more than a fifth of the total revenue from taxes of the general Government, is of special interest in that it throws the burden of direct The Land and taxation almost altogether upon the Income Tax large landholders and other wealthy 
people. Also, it is a partial application of the theories of George and Wallace, although the suggestion that special taxes should be levied upon land did not originate with them.

As far back as the year I 844 , Lord John Russell sent a circular letter to the colonial governors of Australia and New Zealand recommending a History of Direct tax on land as the form of taxation most Taxation suitable to the conditions prevailing in a new and growing community, but thirtyfour years elapsed before such a tax was imposed. In I 844 Governor Fitzroy, who was an ardent advocate of free trade, passed an ordinance abolishing customs duties and substituting a graduated property and income tax of one per cent. on property and income combined up to $£_{I, 000 \text {, }}$ but no taxpayer was liable for more than $£_{12}$. The change was welcomed by the traders and whalers, but the settlers ignored or evaded the law, which soon failed as a means of raising revenue and was replaced by a new customs tariff. No further attempt was made to impose direct taxation until 1878 .

At that time the Colony was prosperous, though on the eve of a crisis, and Ballance considered that the burden of taxation should be readjusted, The Land Tax in order to make the landowners pay a of 1878

larger share of the interest on the public debt, incurred chiefly for the building of roads and railways, which had greatly increased the value of land. By the Act of $\mathbf{I} 878$ a levy of $\mathbf{I}-2 d$. in the pound was made on the capital value of real estate, less the assessed value of improvements. Although this was by no means a heavy tax it stirred up much opposition among the more well-to-do landowners, and, after the fall of the Grey Government in I879, the Act was repealed. 
(Land-tax Act, I878. Reeves, "State Experiments," Vol. I, p. 258.)

Atkinson now brought forward a bill to establish a general property tax on the American model, and the Act was passed on December I9, 1879. (Property Tax Act, I879.) It provided for a tax of one penny in the pound The General Property Tax (five-twelfths of I per cent.) on all assessed real and personal property, with an exemption of $£_{500}$. Atkinson admitted that much was to be said in favour of taxing unused lands held for speculative purposes, but considered the policy impracticable. An income tax, also, he rejected as "too inquisitorial and unavoidably open to great inequalities," nor did he think it advisable to attempt to break up the large estates by means of a progressive land tax. The property tax remained in force until I89I, when it was repealed. The following table shows how the tax was paid in the year I88I :

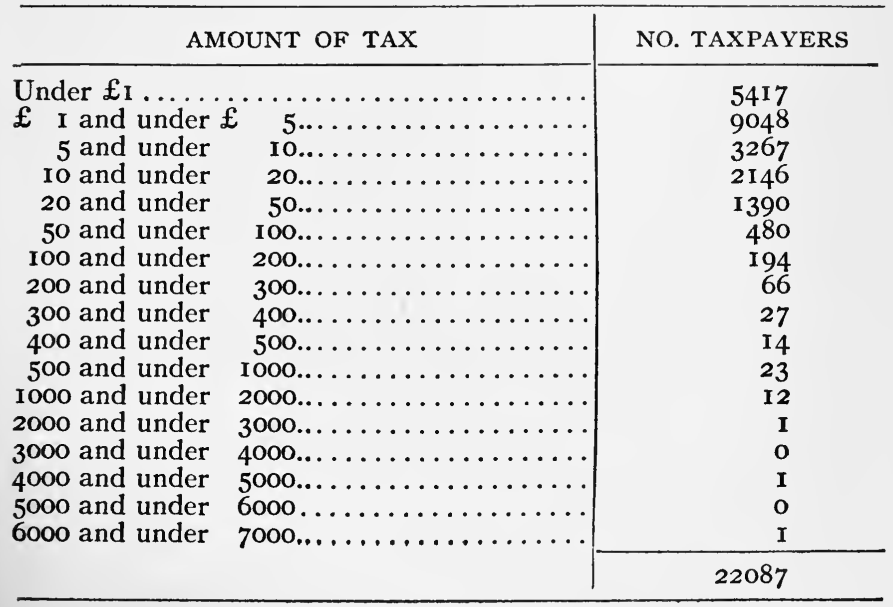




\section{STATE SOCIALISM IN NEW ZEALAND}

The property tax, though by no means onerous, soon became unpopular, chiefly among the small farmers and Objections urged against the Property Tax tradesmen. The usual objections, some valid, but many trivial or baseless, were urged against it. The farmers disliked paying taxes, however small, upon buildings, implements, and live stock. They suspected their rich neighbours of successful evasion, especially those who owned stocks and other personal property which could be easily concealed. The tradesmen thought that they paid too much as compared with professional and salaried people, although they shifted a large part of the tax to the shoulders of their customers. It was said that income from property paid too much as compared with income from professional services and salaries. It is interesting to note that the very opposite of this argument is urged against the present income tax.

Again, it was held that the law took no account of the earning power of a man's capital, and that people doing a large business on a small capital paid less than their fair share, quite ignoring the principle of diffusion of taxes and the tendency towards the equalization of profits. Mr. Reeves said in Parliament that the tax was equal to an income tax of $4 s$. in the pound on a man who was making 6 per cent. on his capital, and only $6 d$. in the pound on a man making $\mathrm{I} 7$ per cent. (Parliamentary Debates, Vol. 7I, p. I90.) Mr. Reeves also says:

"Manufacturers, shopkeepers, and trading companies also found the tax unjust. It hit them as hard in bad years as in good." (State Experiments, Vol. I,·p. 259.)

This, of course, is an objection that can be urged against almost any form of direct taxation, since a Government requires practically as much revenue in bad 
years as in good, and a system of taxation which yields a fluctuating revenue is far from satisfactory.

Mr. Reeves further says:

"To these solid grounds for discontent was added the sentiment nourished by the writings of George and Wallace. Avowed single-taxers were, indeed, very few in number, as they still are; but the doctrines of land-nationalizers and single-taxers were acceptDoctrines of single-taxers able to the extent of distinguishing between real estate and personal property as subjects for taxation. A line was also drawn between ground values and improvements. Large tracts of most of the great freeholds were unimproved. Feeling ran high against land monopoly in 1890 , and higher still against absentee ownership. The land and income tax bill of Ballance was greeted as a measure of revolution. It did indeed herald a species of political revolution, which is still in peaceful progress." ("State Experiments," Vol. I, p. 260.)

Another reason for abolishing the property tax was that the Government required more revenue, and it was thought that this could be secured more easily by taxing the wealthy classes than by increasing the rate of taxation on property in general, which would have aroused a storm of opposition. But, whether for one reason or another, the property tax was condemned by the small farmers and tradesmen; and when, in I89I, these classes got the upper hand, with Ballance, the author of the land tax of 1878 , as premier, they repealed the Act of 1879 and passed the Land and Income Assessment Act in its stead.

Behind all the arguments against the property tax was the determination of the small proprietors to pay little or nothing in the way of direct taxes, but to make the wealthier people pay all. They also wished to break up the large estates, and in this they were

Agitation against the Large Landholders strongly supported by the labouring class, who desired that they or their sons might occupy relatively improved and well-situated land instead of having to endure the hardships of pioneer life in the back blocks. Again, the 
small proprietors, who were mostly borrowers, wished to get at the money lenders by means of a tax on mortgages, which it was thought could not be shifted. Also, they used the arguments of single-taxers in so far as it suited their purpose to do so, although the small farmers, who formed the backbone of the new democracy, were anything but single-taxers. A special tax was levied upon absentee landholders, who were thought to be a particularly undesirable class of citizens; and the income tax was added in order to catch the wealthy merchants, manufacturers, and professional people of the towns. (Land and Income Assessment Act, I891.)

The original Act has been amended from time to time. The Consolidation Act of 1908 is now in force. The most notable features of the Act are the ordinary land tax, including the tax on mortgages on land, the graduated land tax, the tax on absentee owners, and the total exemption of small properties and incomes.

The ordinary land tax is assessed on the unimproved value, that is, the value of the land alone apart from all improvements, or what the land The Ordinary would sell for without improvements. Land Tax

This is not to be confounded with "prairie value," that is, the original value of unsettled land. Unimproved value may be regarded as composed of two elements-prairie value plus community value. The Act of I891 allowed deductions for improvements up to $£_{3}, 000$, but, by the amendment of 1897 , the value of all improvements was exempted. The rate is fixed by the annual taxing Act. At present it is $\mathrm{I} d$. in the pound (4-Io of I per cent.) on the unimproved value. Owners of land of which the unimproved value is $£_{500}$ or less pay no tax.

The tax on mortgages on land was formerly the same 
as the tax on land, but in 1902 the rate lowered to 3-4 $d$. in the pound and has not since been changed. The tax is paid by the mortgagee, that is, the mortgagee and the

Tax on

Mortgages mortgagor are treated as joint owners of the land. In making up the total assessed valuation on which an owner pays taxes, the amount of mortgages owing by him is deducted from the unimproved value, while the amount of mortgages owing to him is added thereto. If such net value is not over $£_{500}$ the owner pays no taxes; if it is $£_{I, 500}$ he pays on $£_{I, 000}$ and there are diminishing exemptions up to $£ 2,500$, at which point the exemption ceases and the owner pays on the full unimproved value.

When the tax on mortgages was first imposed it was said that it would fall on the borrowers, since the lenders would charge a rate of interest high enough to recoup themselves. Mr. Reeves states that such has not been the case (State Experiments, Vol. I, p. 26I), but

Incidence of the Tax on Mortgages the tax was small and its effects were obscured by changes in the rate of interest due to other causes. From I89I to about $\mathrm{I} 898$ the rate of interest on mortgages declined, but afterwards rose. In the year $1898-99$, about 58 per cent. of the money lent on mortgages was lent at 5 per cent. or less, but in the year $1907-08$ only 55 per cent. was lent at such rates. It seems probable that, if the tax had not been imposed, the rate of interest would have fallen more during the former period and would have risen less in the past few years.

At a conference of the New Zealand Chambers of Commerce during the recent financial stringency, a resolution was passed condemning the mortgage tax, and some weeks later the New Zealand Farmers' Union resolved: 
"That this conference endorses the resolution passed by the conference of the united Chambers of Commerce, to the effect that the mortgage tax be abolished, and that taxation on mortgages be in the form of an income tax." (Evening Post, April 13, 1909; Ibid. July 29, I909.)

The graduated land tax, which was designed chiefly to compel the large holders to sell or otherwise subdivide their estates, was altered in 1907 in the The Graduated direction of increasing the tax on the Land Tax larger holdings. (An Act to Amend the Land and Income Assessment Act, I900. October 26, 1907.) It begins with a tax of $\mathrm{I}-16$ of a penny in the pound when the unimproved value in any assessment is not less than $£_{5,000}$ and is less than $£_{7}, 000$, and increases by sixteenths to I3-16 of a penny when the unimproved value is between $£_{35}$,000 and $£_{40}$,ooo. When the unimproved value is $£ 40$,ooo the rate is suddenly increased to $8 s$. in every $£$ Ioo (0.4 of I per cent.), and for every additional $£_{I}$,ooo of unimproved value the rate is increased by $\mathbf{I}-5$ of a shilling in every $£$ Ioo. The rate reaches its maximum at $£ 200,000$, when it is 2 per cent. on the total unimproved value. For and after the year ending March 3I, I9Io, the progressive taxes on estates over $£ 40,000$ are to be increased by 25 per cent. in the case of land other than business premises.

The total ordinary and graduated taxes paid by the owners of large estates are now very heavy. An estate of which the unimproved value is Heavy Taxation $£ 200,000$ pays a graduated tax of $2 \frac{1}{2}$ per of Large Estates cent. in addition to the ordinary land tax of $\mathrm{I} d$. in the pound ( $0.4 \mathrm{I}$ of I per cent.), making 2.9I per cent. in all. But the graduated tax is increased by 50 per cent. in the case of absentee owners, so that the absentee owner of an estate of which the unimproved value was $£ 200,000$, if such an estate existed, 


\section{THE LAND AND INCOME TAX}

would pay a tax of 4.16 per cent. By the Amended Act of 1907 a person is deemed to be an absentee " unless he has been personally present in New Zealand for at least one-half of the period of four years immediately preceding the year in and for which he is assessed for graduated land-tax." (An Act to Amend the Land and Income Assessment Act, 1900. October 28, 1907; Year-Book, 1908, pp. 563,669 .)

The purpose of the graduated tax is to bring about a subdivision of the great estates and it has had some effect in this direction, as has been shown in the Chapter on Land Monop- Loss of Revenue oly. But some, at least, of these estates, are Divided instead of being broken up and sold to small holders, have merely been divided among the members of families, before or after the death of the owners, while the Government has lost a good deal in the way of graduated tax. This loss has amounted to $£ 28,186$ in the twelve years from 1896 to 1907 . The Government has lost more than this by having purchased and subdivided certain large holdings, under the land for Settlements Act. The graduated taxes that would have been paid had the estates remained intact has been estimated at $£ 82,909$ for the eleven years from I 895 to I905, besides the loss on the Cheviot Estate, which was purchased under another Act. (Return B. 24c, Session of 1907; Return B. 24A, Session of 1905.) But the graduated tax is designed to break up the large estates, and when this work is accomplished the revenue now derived from this source will have to be raised in some other way.

The taxation of unimproved values naturally brought about a radical change in the methods of valuing property, but before the year 1896 there was no uniformity 
in this matter. The Land and Income Tax Depart-

Valuation of Land

of making up its roll for the levying of rates. But in 1896 the Government Valuation of Land Act was passed (since amended seyeral times), for the purpose of securing uniformity in valuation, particularly in the administration of the land tax and the rating on unimproved values. (Year-Book, I 909, p. 550.)

The Act provides for the appointment of a valuergeneral and district valuers to hold office during pleasure. The district valuers reside in their districts, soon become expert in their work, and generally command the confidence of the people. There is little or no corruption or bribery. The valuation is not made at stated times, but is constantly being revised, although it is sometimes out of date. The officials say that there are no insuperable difficulties in the way of distinguishing unimproved values from the value of improvements. The Amendment of 1900 gives elaborate definitions of unimproved value, value of improvements and other terms, for the guidance of the valuers. (The Government Valuation of Land Act, I896, and Amendments of 1900 and I903.)

The farmers as a class are not satisfied with the system of valuation and think that it is frequently inequitable. The following resolution was passed unanimously at a meeting of the New Zealand Farmers' Union at Wellington on July 28, I908:

" (I) That the present system of revaluation of rural land for lanp tax purposes upon the unimproved values is inequitable, and is no reliable basis to enable anyone to make a valuation other than a purely arbitrary one; (2) that a capital value is the only ascertainable value which can be equitably arrived at; and (3) that the taxable and rateable value on which the average capital value of land is taken be over a series of years, and not the saleable value of the day." (The Evening Post, Wellington, July 29, I908.) 


\section{THE LAND AND INCOME TAX}

The valuation of all the land improvements was completed in 1898 . The unimproved value was given as $£ 84,40$ I , 244, and the value of improvements $£_{54,196,103}$.

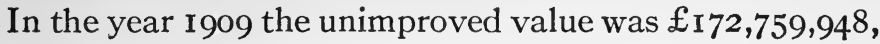
and the value of improvements $£ 98,756,022$, making together a capital value of $£ 27$ I,516,022. (Year-Book, I909, p. 558.)

Of late years there has been a good deal of speculation in new lands; speculative values have in many cases run ahead of permanent investment values; and the Valuation Department has been accused of encouraging speculation by

Speculative

Values overvaluing the land. There are several reasons why the valuation tends to be high. In the first place, the Department wishes to make a high valuation in order to secure a large revenue from the land tax. Secondly, the Government likes to show a high valuation because it is an indication of prosperity and strengthens the Government's credit in the loan market. Thirdly, the owners like to have a high valuation when they come to sell their land or to borrow. Fourthly, if the owner insists on a low valuation, the Government may purchase the land at the owner's valuation. True, the owner has, under the Act, the right to demand that the Government purchase his land at the Government's valuation, or to have the valuation reduced, but there may be reasons why an owner might not want to do this. At any rate, there has been little protest against the Government's valuation until recently, when speculative values have fallen off and the land tax has become a burden. And yet, a record of a number of sales made in 1908 showed that the properties, which sold for $£_{I}, 723,937$, were valued at only

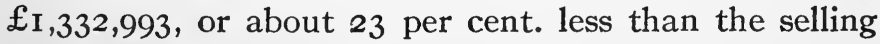
value (Evening Post, Speech by Dr. Findlay, July 3I, 


\section{I32 STATE SOCIALISM IN NEW ZEALAND}

1909; Budget, 1909). But values seem to be high from the investor's point of view, and it is a question whether a farmer can earn interest on either the selling value or the governmental valuation.

The income tax is complementary to the land tax, being levied upon incomes derived from sources other than land and mortgages on land. It is a graduated tax, with an exemption of $£_{300}(\$ 1,460)$, The Income Tax which, however, is not allowed to absentees. Life insurance premiums on the taxpayer's own life are exempted up to $£ 50$. Before the year 1910 the rate was $6 d$. in the pound ( 2.5 per cent.) on the first $£_{\mathrm{r}, 000}$ of taxable income, after allowing the exemptions. On incomes in excess of $£_{I, 300}$ the rate was $\mathrm{I} s$. in the pound ( 5 per cent.). In the session of 1909 an amendment was passed providing for a new scale with more grades, and it was anticipated that an additional revenue of about $£ 80,000$ would be secured in this way. Companies enjoy no exemptions, but friendly societies, building societies, savings banks, co-operative dairy companies, and charitable and educational institutions are wholly exempted from the income tax. No distinction is made between incomes derived from property and those derived from earnings.

The Department is very strict in the administration of the tax, using an elaborate system of inspection and investigation and inflicting penalties for incorrect or fraudulent returns, so that there Little Evasion is very little concealment of incomes derived from investments in New Zealand. The tax on incomes from investments abroad could be more easily evaded. The yield of the income tax for the year 1908-09 was $£_{321,044}(\$ 1,560,000)$, while the land tax yielded $£ 604,901 \quad(\$ 2,940,000)$. 
Farmers complain that they are taxed more heavily than merchants and professional men; but, in view of the large profits they have made in recent years and the great increase in the The Farmers value of their land, they do not seem to complain have any serious grievance. Besides, profits in all kinds of business tend to equality, and no class of people except landowners can derive a permanent benefit from exemption from taxation. Also, the small farmers, as well as the small shopkeepers and all other people of small means, are wholly exempted from the land and income tax, which is paid altogether by the more well-to-do people. The land tax, therefore, is quite different from the single tax proposed by Henry George, who would have society appropriate the whole economic rent of land, whether owned by large or small proprietors.

The success of the small proprietors in getting rid of the burden of taxes by substituting the land and income tax for the hated property tax was truly remarkable. In the year I 889 the num- Small Farmers ber of taxpayers paying property tax was pay no Land Tax 26,327 , or 4.3 per cent. of the European population. In the year $1892-93$ there were 12,360 persons paying land taxes and 3,448 paying income taxes, making in all $\mathrm{I} 5,808$ taxpayers, or 2.5 per cent. of the population. In fact, the number of taxpayers was somewhat less than this, since some persons paid both land and income taxes. (Report by the Commissioner of Taxes, C. B. Crombie, July 28, I 893; Year-Book, I 893, p. 425.)

The number of persons paying land and income taxes has increased both absolutely and relatively since I 893 , because of more careful administration and because of the increase in wealth of a considerable class of 


\section{I34 STATE SOCIALISM IN NEW ZEALAND}

people, formerly struggling farmers and shopkeepers. In the year 1908-09 there were 30,855 perDirect Taxes sons paying land taxes, out of I28,0 I9 paid by the Rich freeholders and 25,204 Crown tenants. The Crown tenants pay no land tax. In the same year there were 10,839 persons paying income tax, making in all 4I,694 taxpayers, or 4.3 per cent. of the population, not allowing for those who pay both land and income taxes. (Parliamentary Return B.-I7A, 1907; Year-Book, 1909, pp. 443, 597.) But most of the taxpayers pay only small amounts, and it is safe to say that by far the greater part of the direct taxes are paid by some 12,000 or 15,000 people. (Parliamentary Returns B.-20, and B-20A, I904.) To this fact may be traced much of the laxity in public expenditure characteristic of the democracy of New Zealand. Back of this inequality in the payment of taxes lies, of course, a corresponding inequality in the distribution of wealth.

In connection with the land and income tax should also be mentioned the stamp duties, an important source of revenue, yielding $£ 534,354(\$ 2,600,000)$ in the year 1908-09. These taxes are paid Stamp Duties upon a great variety of instruments, including affidavits, agreements, annual licenses of companies, assignments, bills of lading, sea insurance policies, certificates of incorporation, conveyances, deeds, receipts, transfer of shares, letters of administration. But the most important are the death duties, which yielded $£ 260,238$ in the year 1908-09 (Year-Book, I909, pp. 594-597). Under the law as it stood before 1909, there was an exemption of $£$ Ioo, and the duties varied from $2 \frac{1}{2}$ per cent. on any amount exceeding $£_{\text {I }}$ oo but not exceeding $£_{\mathrm{I}}$, oco up to I3 per cent. on estates valued at $£ 20,000$ or more left to 
strangers in blood. In the session of I 909 an amendment Act was passed allowing an exemption of $£_{500}$, but providing for increased duties on the larger estates. A distinction is drawn in the new Act between estate duties on the total value of an estate and succession duties on the shares of the beneficiaries. The estate duties vary from I per cent. to 15 per cent., according to the value of the estates, and the succession duties are additional. It was estimated that the new scale would produce additional revenue amounting to about $\$$ I50,000. (Parliamentary Debates, Vol. I48, pp. 44I-454, Nov. 29, I909; The Evening Post, Nov. 26 and Dec. I, 1909.)

In discussing the proposed duties Mr. Baume said in the House:

"I do take very strong exception to the stoppage of the graduation at I5 per cent. . . In my opinion the graduation should go higher. In my opinion, at any rate, there could be no objection to it going as high as 25,30 , or even 40 per cent."

Can Capital be driven away by Taxation?

In a similar vein $\mathrm{Mr}$. Laurenson said:

"This Bill proposes to get at the wealthy classes. The honourable gentleman (Mr. Herdman) says that it is an increase of taxation. As I have already pointed out, it does not amount to an increase of taxation so much as it is a legitimate attempt to aid in the distribution of wealth."

In opposition to this view Mr. Herdman said:

"We want industries here; we want to simulate enterprise; but if you attempt a system of taxation which makes people afraid, which frightens the capitalist, and rather tempts him to send his money away, then, I think, recollecting that this country is at the commencement of its career, we are adopting a policy which is unwise."

In reply to this Sir Joseph Ward said:

"If a man goes away out of the country, and takes his fortune with him, he cannot take the land or the sheep that represent that fortune. He must sell to somebody else, and everybody is not going to leave New Zealand and so escape the death duties." (Parliamentary Debates, Vol. I48, pp. 448, 453.)

The people of New Zealand are very much taxed, not- 


\section{I36 STATE SOCIALISM IN NEW ZEALAND}

withstanding the fact that the Government carries on a number of enterprises which one would

State Trading has not relieved the Tax Payers

think should yield a profit and afford relief from taxation. But these enterprises are not managed so as to yield a true profit, and in some cases they result in a deficit. The railway deficit for I908-09 was about £2I2,000 ( $\$ \mathrm{I}, 03 \mathrm{O}, 000)$, about twice the revenue derived from the beer duty. The interest on the net public debt, that is, the gross debt less the value of the productive investments, was about $£_{\mathrm{I}, 000,000}(\$ 4,860,000)$, more than enough to absorb the entire revenue from the land and income tax. Then there is the sum of $£_{345}, 630$, given to the aged poor in the form of pensions, which is about two thirds of the revenue from the stamp duties. Also, there has been for some years a large surplus of revenue over expenditure, most of which has been transferred to the Public Works Fund, chiefly for public buildings, roads and bridges. There has also been some extravagance in expenditure, due chiefly to the prosperity that has prevailed during the past twelve years, but partly, no doubt, to the fact that the people who vote for the expenditure are not those who pay the taxes.

It is possible and even probable that there will be reform in public expenditure in the near future. The Government has lately announced its intention to try to make the railways earn at least the interest on their capital cost. It is possible that the unproductive part of the public debt may be paid off, or that the governmental enterprises may become more productive, so that the enormous burden of interest may be taken away. Then, too, the Government has proposed and begun a system of economics in the civil service from which much is expected. 
But it is not at all likely that any of these reforms will bring relief to the taxpayers. There may be a larger surplus to spend on roads and bridges, or some of the public debt may be paid off, Taxes likely or the amount expended on old age pen- to Increase sions may be increased; but taxes will increase, for the political power has passed away from the wealthy class, who pay most of the taxes, into the hands of a democracy of relatively poor people who are now taking their turn at exploiting the rich, and regard the capitalist as a cow to be milked or a goose to be kept for the sake of its golden eggs. 


\section{CHAPTER VIII}

\section{LOCAL TAXATION OF LAND}

THE revenue of the cities, boroughs, counties, road boards, and other local governing bodies is derived only

Revenues of Local Governing Bodies

in part from taxation. In the year I907-08 their total revenue was $£_{3,106,-}$ 992 , of which $£ 1,356,257$, or less than half, was derived from rates. Of this amount $£ 949,138$ consisted of general rates, and the balance of special rates, for water and other special purposes. The total amount of local taxation, including rates, licenses, and other taxes, was $£_{\mathrm{I}, 466,598 \text {, or about }}$ $£_{1.52}(\$ 7.32)$ per head of the European population. The local taxes, then, are only about one fourth of the total taxes, three fourths being raised by the general Government. The relative unimportance of the local bodies is largely due to the fact that the system of public instruction is wholly supported by the general Government, which in addition grants large subsidies to the local bodies. (Year-Book, r909, pp. I95-201.) The revenue derived from the general rates alone is equal to $£ .98(\$ 4.80)$ per head of the population.

Before the year I 896 rates might be levied upon the capital value or the annual value of real estate, at the option of the local authorities. The an-

Taxation of Real Estate nual value is an estimate of the rental value of property, which cannot in any case be less than five per cent. of the fee simple. Capital value is the value of the fee simple, if held free from encumbrances.

(An Act to Consolidate 


\section{LOCAL TAXATION OF LAND}

the Law for Regulating the making and levying of rates, 1894.) The system of rating on the annual value is preferred by most of the boroughs, while the counties usually levy on the capital value.

The passage of the Land and Income Assessment Act of I89I called the attention of the local bodies to the possibility of a third form of rating, the rating on unimproved values, which had Rating on Unalready been strongly urged by the fol- improved Values lowers of Henry George. Besides, there

were the usual objections to the existing methods of rating, and there was a certain amount of speculation in land, which in some places was withheld from sale and kept unimproved in anticipation of enhanced values. The labouring class, too, complained of high rents. Also, the proposed Government Valuation of Land Act, passed on October I 7, I896, promised to give the local bodies a convenient basis for taxation without expense to them.

For all of these reasons, but largely through the activity of a few " single-taxers," the Rating on Unimproved Value Act, of August I3, I896, was passed, giving the local bodies a third option in regard to the basis on which rates might be levied. The bill was first introduced as part of the General Rating Bill in $\mathbf{1} 893$, and then as a separate bill in $1894, \mathbf{1} 895$ and 1896, when it was finally passed. In every case the Upper Chamber was responsible for its rejection.

Strange to say, there was a strong country element among the advocates of the bill and many of the best speeches in support of it came from rural representatives, while some of the best Relation to in opposition were made by city and Single Tax borough members. Several speakers who supported the bill strongly disavowed any leanings 


\section{I40 STATE SOCIALISM IN NEW ZEALAND}

towards what one of them called "that infamous proposa', the single tax." On the other hand, Mr. O'Regan, an ardent single-taxer, declared that "even Henry George could not have drafted a more logical bill than this." A good deal of reliance was placed on the fact that a similar act had been passed in Queensland in 1890. Indeed, one industrious historian unearthed the interesting discovery that, under the old provincial Ordinance of 1858 , rating on unimproved values had been in operation in Taranaki for many years. The Ordinance stated that "within the town district an uniform rate per cent. to be assessed on the value of all lands within the district, exclusive of all buildings, erections and improvements whatsoever, shall in every case be imposed, such value to be ascertained as hereinafter provided." This was many years before Henry George became an influence in the Colony.

The Act provides for local option in taxation, in that boroughs, counties, and other rating bodies may decide as to whether their rates shall be levied on the unimproved value, as determined Local Option by the Government's valuation, or upon the annual or capital value of real estate as formerly. A written demand, signed by from I5 to 20 per cent. of the ratepayers, according to the number of ratepayers in the rating district, must first be presented to the Chairman of the district, requesting that the Act be submitted to a vote of the ratepayers, and the vote must be taken between twenty-one and twenty-five days after delivery of the demand. (The Rating Act, 1908.)

Under the original Act it was necessary for at least one third of the ratepayers to vote, and a majority of their votes carried the proposal. Because of this pro- 
vision the Act failed to be carried in a number of districts, but now the Local Government Voting Reform Act provides that a bare majority of the valid votes recorded is sufficient to adopt the Act. If the Act is adopted, no rescinding proposal can be submitted to the ratepayers until the expiration of at least three years, and if a rescinding proposal is carried no adoption proposal may be submitted until after three years have elapsed.

\section{Section 20 of the Act reads as follows:}

"This Act shall not apply to water rates, gas rates, electriclight rates, sewage rates, or hospital or charitable-aid rates."

The reason for the exclusion of these Exceptional Rates rates was that they represented service to buildings alone. In committee Mr. O'Regan moved an amendment having for its object the levying of thess exceptional rates on the unimproved value, but this wae lost by a large majority. (Parliamentary Debates, Vol. 85, p. 192.)

A similar attempt was made during the parliamentary session of 1905, when a bill was introduced by $\mathrm{Mr}$. Henry George Ell to amend the principal Act so as to permit the local authorities to levy "all or any of the rates menSingle Taxers not Satisfied tioned in Section 20 upon the unimproved value." This proposal excited great opposition and a spirited debate, and the bill was lost. It shows, however, that the single-taxers are not satisfied with the small measure of land taxation which they have secured, and that they favour local option only as a means to an end, and, if possible, would make rating on unimproved values not optional but mandatory in every rating district in the Dominion. (Parliamentary 
Debates, Vol. I32, pp. 564-579, Vol. I33, pp. 692-719.)

Up to March 3I, I909, the proposal had been submitted to the ratepayers in various districts I03 times, had been adopted in $8 \mathrm{I}$ districts and reThe Act in jected in 22, but in 4 of these it was Operation afterwards carried. In the year 1908 it was carried in 3 districts and rejected in 3. On March 30, 1908, the borough of North East Valley, which had adopted the Act on January I2, I905, by a vote of 202 to $I 72$, voted to rescind by a vote of 354 to $I 85$. This is the first case of rescission, although several proposals to rescind have been defeated. (Year-Book, I909, p. 215.) Until recently the vote has seldom been a large proprotion of the total ratepayers, but latterly the proposal has been more stubbornly contested. In the contest in the Borough of Birkenhead on February 9, 1910, $44 \mathrm{I}$ votes were cast out of a total of 620 voters and the proposal was rejected by a majority of 55 . Referring to this contest, Mr. Vaile, a strong opponent of the single-tax, says:

"Where the system has been carried in this country it has almost always been by surprise. The advocates of the new system canvassed carefully before they applied for the poll which they forced on at the shortest possible notice; very few went to the poll and of course the single-taxers had the advantage."

The indifference of many ratepayers is probably due chiefly to the fact that the rates in most districts are not a heavy burden upon the owners of propIndifference of erty. The general Government supthe Ratepayers ports the public schools and many charitable institutions, spends large sums of money on roads and other public works, bears the expense of valuation, and even grants subsidies to the local bodies. The chief items of local expenditure are for roads, bridges, drainage, harbours, charitable aid and hospitals. 
Besides, less than half of the local revenues are derived from rates. In the year $1907-08$, if all the general rates had been levied on the unimproved value, the tax would have been about one half of one per cent. upon the valuation. In the rural districts the tax would have been lower than this; in the towns it would have been higher. Rating on unimproved values is, therefore, by no means a thoroughgoing application of single-tax principles.

In the year 1906 the New Zealand Government, at request of the British Government, sent a circular letter to all the local authorities rating on the unimproved value, requesting informa- Investigation by tion as to the working of the system. Of the Government the 52 replies received about 38 were fairly satisfactory, but only a few covered all the points about which information was desired. The following is a rough classification of the replies:

I. There is a general agreement that rents have not been reduced, and that the incidence of taxation has been changed so as to fall more heavily upon unimproved land and upon land on which there are improvements the value of which is less than the unimproved value. Out of I I opinions concerning the justice of this change of incidence, 4 say that it is more equitable, while 7 say that it is unjust or onerous.

2. As to speculation in land, I5 say that it has been discouraged, and only I holds the contrary opinion, while 3 say that vacant sites have been broken up and put upon the market.

3. As to the building trade, 12 say that it has been encouraged, 8 think that it has not been affected, I says that it has been discouraged, and I says that it has been unduly stimulated to the point of overcrowding.

4. Out of 25 replies expressing opinions as to the 


\section{I44 STATE SOCIALISM IN NEW ZEALAND}

general popularity of the system, 20 say that it is satisfactory or beneficial, and 5 say that it is not so.

The replies were sent to the British Government, together with a memorandum by Mr. P. Heyes, the Commissioner of Taxes, who is strongly in Memorandum favour rating on unimproved values. by Mr. Heyes (Papers relative to the Working of Taxation of the Unimproved Value of Land in New Zealand, New South Wales, and South Australia. London, I906.) His report is more favourable than the somewhat unsatisfactory replies of the local authorities would seem to warrant. He says:

"From the reports received, and the most reliable sources of information available based on personal observation and inquiry, I am of opinion that the effect of the system of rating on the unimproved value would be correctly summarized on the lines required as follows:

"Building Trade: The effect has certainly been to greatly stimulate the building trade. The object and tendency of this system of taxation is to compel land being put to its best use, so that the greatest amount of income may be derived from it, and rendering it unprofitable to hold land for prospective increment in value. It has been the direct cause of much valuable suburban land being cut up and placed on the market and thus rendered more easily available for residential purposes, and of the subdivision of large estates in the country, resulting in closer settlement. The effect on urban and suburban land has been very marked. The rebuilding of this city (Wellington) which for some years past has been rapidly going on is largely attributable to the taxation and rating on land values.

"Rent: The tendency of this system of taxation is not to increase rent, but, on the contrary, as the tax becomes heavier, it tends to bring into beneficial occupation land not put to its best use and so reduces rent, the improvements being entirely free from all rates and taxes. In some cases where land suitable for building sites is limited high rents have been maintained, notwithstanding the tendency of the system.

"Vacant Sites: The effect has been to cause vacant sites being put to their best use by expenditure on improvements. On vacant sites the rates and taxes are increased and continue to increase as the adjacent sites which have been improved increase in value. It thus becomes unprofitable to continue to hold land unimproved.

"Incidence of Taxation: The taxation on building property, where the improvements exceed the unimproved value, is decreased; where the unimproved value exceeds the improvements the taxation is increased. 
"Land Speculation: The tendency is to discourage speculation as the tax partially or wholly discounts the rise in value, but land speculation has not ceased in some districts where the system has been adopted, because the tax has not been sufficient to render speculation unprofitable in large cities, and because of the rapid increase in land values in spite of the tax.

"In my opinion the exemption of all improvements (in conjunction with the Lands for Settlements and Advances to Settlers policy of the Government) has to a large extent contributed to the solid prosperity of the Colony."

Before the Government's report was accessible the present writers made a similar investigation by means of a series of questions sent, in December, I 906, to the clerks of all the local bodies, 69 in number, that had adopted the Act.

Another

Investigation Forty replies were received, of which thirty-five gave fairly satisfactory answers. The questions and a summary of the replies are here given:

I. Has the system had any marked effect in discouraging the holding of land for speculative purposes? Yes, 12; no, I9; indefinite, 4.

2. Has the system unduly forced people to part with land used for private gardens? Yes, 4 ; no, 22 ; indefinite, 9.

3. Do you attribute to the system any alteration in the prosperity of your county, district, or borough? Yes, 4; no, 22; indefinite, 9 .

4. Has the system caused any appreciable increase of buildings or other improvements? Yes, I2; no, I4; indefinite, 9 .

5. Has the system caused buildings to be erected in advance of requirements? Yes, 3 ; no, 32 .

6. (a) Do you consider the system to work equitably? Yes, I9; no, 9. (b) Do you know of any cases of hardship? If possible, give details. Yes, I4; no, 10.

7. Has it had any effect in $(a)$ cheapening land, or (b) making it easier to get? (a) Yes, 5; no, 28. (b) Yes, I2; no, 22. 
8. Do the ratepayers and public seem satisfied with the system? Yes, 22; no, 3; indefinite, Io.

In further explanation of these questions and answers it should be noted:

I. The tax is too slight to have any marked effect in discouraging speculation, especially in view of the general rise in land values, but in some

Results

Insigrificant cases weak holders have been compelled to sell to stronger holders, or to buyers of small lots for building.

2. In a few places, as in Wellington, where there is a great scarcity of building sites, the tendency already existing toward overcrowding has been increased. A higher tax would have a still greater effect in this direction. This was clearly foreseen by the present Chief Justice, Sir Robert Stout, who led the opposition to the bill in Parliament. He predicted that the effect of the law would be to do away with the vacant spaces - the lungs of the cities. Certainly, the taxation of unimproved values does not seem to be in harmony with the Garden City idea. A garden, or even a vacant lot, is often more of an "improvement" to a neighbourhood than a building. In fact, buildings are frequently the very opposite of "improvements."

3-4. The increase of buildings and other improvements has been due chiefly, if not altogether, to the Prosperity not general prosperity of the country, which due to Rating in its turn has been due to the high on the Unim- prices for wool, mutton and dairy produce proved Value that have prevailed during the past ten or twelve years. Districts where the old system of rating has been retained have prospered as much as the others, as can be seen by an examination of the Census reports for I90 i and I906. For example, two of the sub- 
urbs of Auckland, Devonport and Grey Lynn, under the new rating, have increased in population by 35 and 43 per cent. respectively; yet the more conservative suburbs of Remuera, Mount Albert and Epsom show gains of 42, 75 , and II 2 per cent. The total population of the $2 \mathrm{I}$ boroughs which adopted the Act before 1904 show an increase in population of 24 per cent., while the total population of all the boroughs in New Zealand has increased by 22 per cent. The total population of the Io counties where the Act was adopted before 1904 has increased by ro per cent., and the total county population of New Zealand has also increased by ro per cent. So there is no evidence to show that the new system of rating has either advanced or retarded the growth of the districts in which it has been adopted. (Census of 1906.)

5. The Tax is not sufficient to stimulate building to any marked extent; but if it were, and a large number of people improved their land for the sake of securing some revenue, and not in response to increased demand, rents in general would fall, and the owners of improved property would lose as much as they had gained by exemption from taxation, or more. At the same time tenants would gain, for a time, by the reduction of rents.

6. The question of equity has transformed itself into a question of the interests of the several classes concerned, and ratepayers commonly vote A Question of on the question according to the gain Class Interests or loss which they anticipate as the result of the proposed change. There are two classes of owners: those whose unimproved value is greater than the value of their improvements, and those who own a relatively greater value in improvements. Owners of the latter class are well satisfied with the rating on unimproved values, since it has reduced 


\section{I48 STATE SOCIALISM IN NEW ZEALAND}

their taxes. Owners of the former class complain when their taxes are materially increased; but since land values have increased almost everywhere, and the rates are not very high, most of these people have lost nothing and feel no great burden unless they hold large quantities of unimproved land.

There are many individual cases of hardship, as when a poor person in a country borough has a vegetable garden or a paddock for a cow. Some

Cases of Hardship industries, too, such as lumberyards, foundries, and dairies, situated within a borough, have had their taxes greatly increased, or have been compelled to move into the country. In the case of a borough partly urban and partly rural the system presses inequitably upon the more rural parts, where the value of the improvements is small in proportion to the unimproved value. Even in urban districts there are inequalities, as where a person owning a large house on a small lot pays less than his neighbour who has a small house on a large lot. As a rule, however, a large house is built upon a large piece of land and a small house upon a small allotment. Moreover, rich people as a rule own more unimproved land than poor people. Therefore, the adoption of the new system probably involves a shifting of the burden of local taxation from the many to the few, from the relatively poor to the relatively rich, who, no doubt, are best able to bear it.

Where the system has been adopted in counties containing towns, the taxes on rural property are relatively increased, so that the country people complain, and demand a system of differential rating, or a separation of the towns from the rural districts for purposes of rating. Again, in rural districts the rates must fall more 
heavily on the holdings of new settlers than on the improved holdings of their more prosperous neighbours.

7-8. Land values have risen greatly, notwithstanding the tax. This, together with the slight amount of the tax, is probably the cause of the general indifference of ratepayers to the question. Many of the ratepayers, if not a majority, have had their rates reduced and are well satisfied with the result. The working class, who are interested in the securing of lower rents and who envy the prosperity of the landowners, are largely in favour of rating on unimproved values, but only ratepayers can vote on the question. The minority who suffer hardship do not seem to have sufficient influence to have the system abolished.

The case of North East Valley is of particular interest since it is the only district that adopted the system and afterwards abandoned it. The borough has a population of 4,467 , and has a very large area containing garden and dairy farms. It adopted rating on unim-

The Case of North East Valley proved values on January 12 , I905, and voted for rescission on March 30, 1908. In reply to the Government's circular, the borough reported as follows:

" Decreases rates on buildings. Increases rates payable on land. Encourages building operations. Attracts population. Does not materially reduce rents. Oppresses holders of land unsuitable for building. Reduces number of vacant sites." (Papers relative Working of Taxation of the Unimproved Value, p. 28.)

In reply to the writers' circular, the answers were, in brief:

"Discourages speculation in land. Forces people to sell private gardens and other land. Has increased prosperity, causing a large increase of building and influx of population. Has not unduly stimulated building, but there is danger of this. Is hard on the farmer. Differential rating should be allowed. It has made land cheaper and easier to get. The majority are eased and therefore satisfied. The minority feel the additional burden." 


\section{I50 STATE SOCIALISM IN NEW ZEALAND}

The radically different views that are held on this subject are well illustrated by the opinions of Mr. Macky, who was Mayor of Devonport in I900, Opposing Views when the borough adopted the new rating, as compared with the views of Mr. Alison, mayor of the same borough a few years later. Mr. Macky gave twelve reasons in favour of the new rating, as follows:

"I. It has removed the heavy rates formerly charged on all improvements.

" 2 . It has greatly encouraged building.

"3. It has given increased employment to labour, and has encouraged trade.

"4. It has largely lightened the taxation on almost all the inhabitants of the borough, who have made Devonport what it is.

" 5 . It has specially reduced the rates on working-men's homes and small residences. landlord.

"6. It has reduced rents without reducing the profits of the industry.

"7. It has encouraged thrift by taking off an injurious tax on

"8. It has discouraged the holding of unproductive areas for an increased value caused by the improvements of neighbours. tion.

" 9. It has made empty allotments bear their fair share of taxaequitable.

"Io. The valuation of the borough costs less and is more

"II. It is fair and just to all, as it makes those pay most who get the greatest pecuniary benefit from the rates and the general expenditure of the borough.

" 12 . It is being adopted by a constantly increasing number of boroughs, counties and road districts, and has proved a success wherever it has been tried." (Parliamentary Debates, vol. I33, p. 704, August 16, 1905.)

Very different are the opinions of Mr. Alison, who says: "As Mayor of Devonport, I am able to speak with some authority with regard to the rating on unimproved values, and I have no hesitation in saying that it is a pernicious system - a system which is entirely unsound and wrong in principle. . . . It is all very well while land is appreciating in value, whilst you can sell readily, whilst business is buoyant, whilst tenants for houses and business places can be readily secured; but let there be a reversal in the condition of things, and houses are unsalable and untenanted, then the injustice which is wrought by rating on the unimproved value will be realized.

The tendency of the system is to encourage owners to build large houses on small sections, and to crowd houses together. . . I could quote a large number of instances at Devonport where there 
are working-men, poor men, who hold two allotments and a small house, whilst almost side by side is the man of wealth with his mansion on a lesser area, and these working-men are paying higher taxation than the wealthy man. . . The majority gain benefit to the detriment of the minority, and do not care what injustice is imposed so long as they gain an advantage for themselves." (Parliamentary Debates, vol. I32, p. 577, July 13, 1905.)

The followers of Henry George give a glowing account of the success of rating on unimproved values wherever tried. The Hon. George Fowlds holds that land taxes, both general and local, have been among the chief causes of the prosperity of the Dominion during the past ten or twelve years. Mr. Ell is strongly in favour of the system, and would have all the rates, including gas and water rates, levied upon the unimproved value. Mr. Laurenson said in the House:

"I can assure you that the rating on unimproved values system will yet be adopted in every municipality in New Zealand. In the next ten years it will be adopted in connection with every class of rate that may be levied in this Colony." (Parliamentary Debates, Vol. I32, p. 577, July I3, I905.)

But the facts do not seem to warrant optimistic conclusions such as these. The benefits of rating on unimproved values are not so obvious as to command unanimous approval or to persuade all the rating districts to adopt it without delay. The opposition to the system appears to be growing stronger as the people are coming to recognize its relation to the propaganda for the single-tax. The small farmers like to shift the burden of taxation from their own shoulders to those of their wealthy neighbours, but they do not enjoy the game when they are on the losing side. They are strong supporters of freehold tenure, and will not readily consent to have their property confiscated by any radical extension of the principle of the single-tax.

The growing political power of the labouring class, for whose benefit much of the recent legislation of New 


\section{STATE SOCIALISM IN NEW ZEALAND}

Zealand has been enacted, may ultimately bring about the nationalization of land, but surely not until the Dominion has become an industrial nation, rather than a pastoral and agricultural community as it is to-day. Up to the present time the effects of rating on unimproved values have been insignificant. The most notable feature of the system is the shifting of the burden of local taxation from one class of taxpayers to another. It is an interesting phase of the tendency which prevails in both New Zealand and Australia toward an equalization of wealth by means of a legal transfer of the property of the wealthier classes to the pockets of their poorer neighbours. How far this process will go it is impossible to foretell, but that its ultimate results will be beneficial to the majority of the people is by no means certain. 


\section{CHAPTER IX}

\section{STATE LIFE INSURANCE}

Statistics show that the death rate in New Zealand is one of the lowest in the world. In the year 1907 it was 10.95 per I, 000 persons living, as compared with 10.58 for New South Low Death Rate Wales; 15 for England and Wales, 13.5 of New Zealand for Denmark, 18 for the German Empire,

20 for France and $\mathbf{1} 7.8$ for the United States. (YearBook, 1909, p. 264; U. S. Census, 1900, Special Report on Mortality.) Among the factors which contribute to this result are a fine climate, a sparse population, healthy occupations, and the youthfulness of the inhabitants. It has been stated that the last-mentioned factor is the most important and that owing to the diminishing birth rate it will not be long before a substantial increase in the death rate must ensue. And yet, the death rate is practically the same as it was twenty-five years ago. ("The Population of New Zealand," by H.W. Segar, M. A., Transactions of the New Zealand Institute, I900, Vol. 33, p. 445; Year-Book, I 893, p. 78.)

In another respect New Zealand beats the world, for it is stated that its inhabitants carry more life insurance in proportion to their numbers than the people of any other nation. ("State Insurance in New Zealand," Year-Book, Popular I894, p. 266.) This is probably due chiefly to the wealth and intelligence of the people, although the low death rate may have something to do with it. In the year 1907 there were twelve companies 
doing life insurance business in the Dominion and they had issued 122,924 policies which insured a gross amount

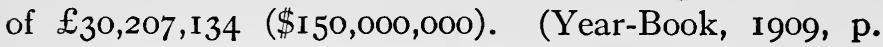
538.) This is a large amount of insurance for a country with a population of about 900,000.

The State Life Insurance Department was established in 1869 at the instance of Sir Julius Vogel, who was at

The State Life

Insurance

Department

Established

nial revenue. The arguments advanced by Vogel are still of interest. He dwelt on the great risks attending life insurance as evidenced by the failure of certain British offices, and claimed that the State was the only assurer which could give the greatest possible amount of security at the least possible cost. He called attention to the British legislation for the granting of governmental annuities which had been carried by Gladstone some years previously, and urged that in a young country where there were so many changes of fortune it was specially important to encourage habits of thrift and providence. He believed that the only way to popularize insurance among the working class was to place the security of the State behind it. The time was especially opportune since there were no vested interests to contend with - no local life assurance companies. All of the insurance business was done by agents working for outside companies which made no investments in the Colony.

The high local rate of interest then ruling - at least 5 per cent. - was another great advantage. At that time the tables of the British companies were framed on a 3 per cent. basis, so that there would be a large margin of 
profit if the funds were invested in the Colony. Vogel also pointed out that the large staff of Government officials throughout the country could be utilized in carrying on branch offices, and that by this means the expenses rate would be kept lower than that of private companies.

Finally, Vogel saw in the scheme a splendid possibility of placing large funds at the disposal of the State without having to repay for many years either principal or interest. The scheme would be advantageous to all concerned; the assured would obtain policies at low rates; and the Government would have the use of their money for many years for the various internal improvements which were soon to be undertaken. However, no attempt was actually made to subordinate the Insurance Department to the general loan policy of the Government.

The Government Insurance Department began operations in 1870 , now 40 years ago. The management is vested in a Commissioner appointed by the Government. The Dominion is Methods of divided into 4 districts, each of which is Business supervised by a district manager who receives a fixed salary and a commission on the net increase in business for the year. Where there is no resident officer the local postmaster is employed. Business is conducted on much the same lines as that of private mutual life assurance offices. All the usual classes of policy are issued and canvassers are employed to obtain new business and paid according to results. The State guarantees that all contracts will be duly met at. death or on maturity of policies. Annual accounts are audited and presented to Parliament; and every three years an actuarial investigation is made and all profits, after suitable reserves have been set aside, are divided among participating policy holders. 
All entrants into the civil service are obliged by law to insure in the State office on a combined assurance and Compulsory and annuity plan. In return for monthly Voluntary In- deductions amounting to about 5 per surance of Givil cent. of salary, the Insurance DepartServants ment gives a uniform initial insurance of $£$ Ioo, increasing with the salary until the age of 60 is reached, and after that an annuity varying with the age at entry. Those who elect to pay a small extra premium can have the assurance continued beyond the age of 60 until death. This scheme was initiated in 1893 . In addition to this compulsory assurance, many civil servants insure voluntarily in the State office. In 1905 there were some 6,000 civil servants insured in the State office, and of the total yearly premiums paid by them, amounting to $£_{44}, 800$, the sum of $£_{39}$, ooo represented voluntary premiums.

For some years after it began operations, the Department's business rapidly increased, its only competitor

Rapid Increase of Business at First being the Australian Mutual Provident Society. On June 30, I873, the Commissioner reported "that 2,90I persons had effected insurances for an aggregate sum of $£_{I, 085}, 649$, and also that 60 persons had provided endowments amounting to $£ 6,500$, while I7 others had paid for annuities of the value of $£ 950$ per annum." (Official Handbook of New Zealand, I875, p. 45, article by Mr. Woodward, Public Trustee.) In the year 1884 the total sum assured was $£ 6,135,636$, in I 892 it was $£ 8,036,220$, in 1897 it was $£ 9,002,601$, and in 1907 it was $£$ ro, 855,153 . (Handbook of 1892, p. 26I ; Year-Book, I899, p. 298; Year-Book, r909, p. 538.)

The following table from the Official Year-Book of 1909 shows in summary form the position of the 
various companies carrying on business in New Zealand in so far as their New Zealand business is concerned:

\begin{tabular}{|c|c|c|c|}
\hline \multirow[b]{2}{*}{ Name of Office } & \multirow{2}{*}{$\begin{array}{l}\text { Number of } \\
\text { Years of } \\
\text { Business in } \\
\text { the } \\
\text { Dominion }\end{array}$} & \multicolumn{2}{|c|}{ New Zealand Business Only } \\
\hline & & $\mid \begin{array}{c}\text { Number of } \\
\text { Existing Policies } \\
\text { at End of Year } \\
\text { I907 }\end{array}$ & $\begin{array}{c}\text { Gross Amount } \\
\text { Insured by } \\
\text { Policies at End } \\
\text { of Year } 1907\end{array}$ \\
\hline Australian Mutual Provi & \multirow{3}{*}{46} & \multirow{3}{*}{36,253} & \multirow[b]{2}{*}{$9,923,173$} \\
\hline 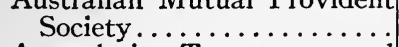 & & & \\
\hline Australasian Temperance and & & & \multirow{3}{*}{258,644} \\
\hline ance Society (Limited) .... & \multirow[t]{2}{*}{5} & 2,475 & \\
\hline $\begin{array}{l}\text { Australian Widows' Fund Life } \\
\text { Assurance Society (Lim- }\end{array}$ & & \multirow[b]{2}{*}{3,232} & \\
\hline $\begin{array}{c}\text { ited) } \\
\text { Citizens' Life Assurance Com- }\end{array}$ & IO & & 799,480 \\
\hline 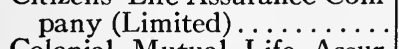 & I4 & 5,693 & 924,464 \\
\hline $\begin{array}{l}\text { Colonial Mutual Life Assur- } \\
\text { ance Society (Limited).... }\end{array}$ & \multirow[t]{2}{*}{24} & 5,477 & $\mathrm{I}, 302,070$ \\
\hline $\begin{array}{l}\text { Equitable Life Assurance So- } \\
\text { ciety of the United States. }\end{array}$ & & \multirow{2}{*}{$\mathrm{I}, 87 \mathrm{I}$} & \multirow[b]{2}{*}{669,142} \\
\hline Mutual Life Association of & 23 & & \\
\hline $\begin{array}{c}\text { Australasia.... } \\
\text { National Mutual Life Associa- }\end{array}$ & $3 I$ & 8,044 & $\mathrm{I}, 908,722$ \\
\hline $\begin{array}{c}\text { tion of Australasia (Lim- } \\
\text { ited) } \ldots \ldots \ldots \ldots \ldots \ldots \ldots \ldots\end{array}$ & \multirow[t]{2}{*}{28} & I I, 96 I & \multirow[t]{2}{*}{$3,261,397$} \\
\hline $\begin{array}{l}\text { New York Life Insurance } \\
\text { Company............... }\end{array}$ & & \multirow{2}{*}{788} & \\
\hline Scottish Metropolitan Life & $2 \mathrm{I}$ & & 269,839 \\
\hline 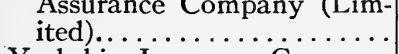 & \multirow{2}{*}{$\begin{array}{r}\text { II } \\
6\end{array}$} & \multirow{2}{*}{$\begin{array}{r}9 \\
\mathbf{1} 76\end{array}$} & \multirow{2}{*}{$\begin{array}{r}3,600 \\
31,450\end{array}$} \\
\hline $\begin{array}{l}\text { Yorkshire Insurance Company } \\
\text { Life Insurance Department }\end{array}$ & & & \\
\hline or tne New Lealand Govern- & 38 & 46,945 & I0,855, I 53 \\
\hline $\begin{array}{l}\text { Totals, December,.1907 } \\
\text { Totals, December, I906 }\end{array}$ & & $\begin{array}{l}\text { I } 22,924 \\
\text { I } 8,265\end{array}$ & $\begin{array}{l}£ 30,207,134 \\
£ 29,036,047\end{array}$ \\
\hline
\end{tabular}

It will be seen that in 1907 the State Office carried a greater total of insurance in New Zealand than any single company. It also held no less than 38 per cent. of the existing policies. Competition of This percentage of policies has, however, panies steadily declined during recent years. 


\section{I58 STATE SOCIALISM IN NEW ZEALAND}

In 1893 it was over 49 per cent. From I897 to 1907 the amount of assurance in force increased from $£ 9,002$,60 I to $£_{10,855,153}$, or 20 per cent; in the same time the business of the Australian Mutual Provident Society increased from $£ 6,640,252$ to $£ 9,923, \mathrm{I} 73$, or 50 per cent. In 1906 it was stated in one of the Department's publications that "the Colony is vigorously canvassed by travelling agents, who obtain the vast bulk of the new business" (A Brief Survey of New Zealand's State Life Insurance, specially prepared for distribution at the New Zealand International Exhibition, Christchurch, 1906-07), but this statement must have referred to an earlier period, since for a number of years the bulk of new business has been done by the A. M. P. and other private companies. From I 897 to 1907 , while the business of the State office, as measured by amount of insurance in force, increased by 20 per cent., the business of all the private companies taken together increased from

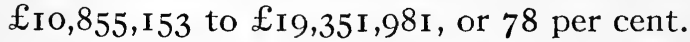

The premiums charged by the State office are usually less than those of any private company. The following table shows a comparison with three of the chief private companies for a whole life ("straight life") policy of £IOO: (Australasian Life Assurance Societies, I9th Edition, 1905.)

\begin{tabular}{|c|c|c|c|c|c|c|c|c|c|c|c|c|}
\hline $\begin{array}{l}\text { Age at } \\
\text { Entry. }\end{array}$ & \multicolumn{3}{|c|}{$\begin{array}{l}\text { New Zealand } \\
\text { Government Life. }\end{array}$} & \multicolumn{3}{|c|}{$\begin{array}{l}\text { A. M. P. } \\
\text { Society. }\end{array}$} & \multicolumn{3}{|c|}{$\begin{array}{l}\text { Mutual Life } \\
\text { Association }\end{array}$} & \multicolumn{3}{|c|}{$\begin{array}{l}\text { National Mutual } \\
\text { Life. }\end{array}$} \\
\hline 20 & $\mathfrak{E}_{\mathrm{I}}:$ & I 5: & 7 & $£_{\mathrm{I}}$ : & I7: & 5 & $£_{\mathrm{I}}$ : & I 7: & $\mathrm{O}$ & $£_{\mathrm{I}}$ : & I6: & 9 \\
\hline 30 & $£ 2:$ & $5:$ & 5 & $£ 2$ : & $8:$ & 2 & $£_{2}$ : & $7:$ & O & $£ 2:$ & $6:$ & 8 \\
\hline 40 & $£_{3}:$ & I: & 3 & $£_{3}:$ & 4: & & $£_{3}:$ & $3:$ & o & $£_{3}:$ & I: & 6 \\
\hline $5^{\circ}$ & $£_{4}:$ & $9:$ & & $£_{4}:$ & 9: & & $£_{4}:$ & II: & o & $£_{4:}$ & $7:$ & 2 \\
\hline
\end{tabular}

During the first fifteen years of its existence the State office made no attempt to provide bonuses, and there- 
fore framed its rates of premium on an even lower scale than that obtaining at the present time. It was discovered, however, that it was necessary to provide bonuses in order to attract new business, hence the present rates have been in force since $\mathbf{I} 885$.

The simplest and most popular method of calculating the expenses of a life office is to take the total expenses and calculate the ratio that this total bears to the total income or the premium Low Expense income of the office. On this basis the Ratio State office when compared with other offices of anything like its own size and age stands out as by far the most cheaply managed. Only two private offices show a lower ratio of working expenses, as appears from the following table: (Australian Life Assurance Companies, 1905.)

\begin{tabular}{|c|c|c|}
\hline Name & $\begin{array}{l}\text { Percentage } \\
\text { of expenses } \\
\text { on } \\
\text { premium } \\
\text { receiprs, } \\
\text { excliding } \\
\text { considera- } \\
\text { tion for } \\
\text { annuities }\end{array}$ & \begin{tabular}{|} 
Percentage \\
of expenses \\
on total \\
receipts \\
from \\
premiums \\
and \\
interest, \\
:excluding \\
considera- \\
tion for \\
annuities
\end{tabular} \\
\hline Australian Mutual Provident Society. & 13.6 & 8.9 \\
\hline Government Life Insurance Office.... & 20.3 & 13.2 \\
\hline National Mutual Life Association........... & $25 \cdot 4$ & 18.9 \\
\hline Mutual Life Association . . . . . . . . . . . . & 27.2 & 20.0 \\
\hline 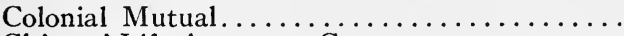 & 29.2 & $2 \mathrm{I} \cdot 9$ \\
\hline Citizens' Life Assurance Co. . . . . . . . . . . . . & I 5.9 & 13.2 \\
\hline
\end{tabular}

Of these offices the National Mutual affords the fairest comparison with the State office. It has about the same amount of funds accumulated, although it has a larger income both from premiums and interest. 'Frequently the State office has been criticised in Parlia-

Comparison with the A. M. P. Society 
ment and elsewhere because its expense rates are higher than the A. M. P. Society. In 1902 the Commissioner made the following reply to this criticism:

"The lower ratio in the case of the A. M. P. Society arises to some extent because of the age of that Society. It was established many years before the Government Department was inaugurated; consequently a vast volume of business was accumulated, practically without opposition. Other reasons partially accounting for the difference may also may advanced:

" (a) Because the premiums of the A. M. P. are considerably higher than those of the Department.

" (b) Because the Government Insurance Department has to pay Land and Income Tax on the whole of its business, whilst any similar payments the A. M. P. Society may have to make in Australia are small in comparison. But if the expenses of management were adjusted and allowance made for the higher premiums charged by the A. M. P. Society, as well as for a fair proportion of head office expenses and a fair proportion of expenses for the actuarial work, which in the case of the A. M. P. Society is all done at Sydney, there is practically no difference." (Quoted in Parliamentary Debates, vol. I20, p. 257.)

Thus far we have been dealing with the simple method of arriving at the amount of working expenses, but Another Method although it is the method adopted by of estimating most financial journals it does not afford the Expense a true means of comparison. On this Ratio

basis a stagnant office, one writing a small amount of new business in comparison with the renewals, must show a lower expense rate than an office with a similar renewal income writing a larger amount of new business.

If we adopt the plan followed by technical writers, the State office shows much less favourable results in regard to working expenses. This method, it is true, is somewhat arbitrary, but is perfectly fair. It consists in assuming either ( $I$ ) that the renewal expense is $7 \frac{1}{2}$ per cent. of the total expenses, from which the expense of new business can be found, or (2) that the new business rate of expense is ten times the renewal rate, so that, if the latter is 7.5 per cent., the former is 75 per cent. 
The latter is perhaps the fairer method, and a comparison of the National Mutual with the State Office shows that the former. works at 9.4 per cent. and 94 per cent., respectively, while the latter's expense rates are 10.6 per cent. and 106 per cent., respectively.

The true reason why the State Office makes such a good showing by the popular method now becomes apparent. In the year in question the State Office wrote only one fourth of the new business written by the National Mutual, while its renewal income was over half that of the latter office. Had the State Office written half as much new business as the National Mutual, the percentage of expenses on premium receipts would have been considerably higher than that of the National Mutual. In other words, the low working expenses of the State Office are attributable much more to slow progress than to any remarkable economy in management.

The amount of bonuses which a policy will probably carry with it always forms a more forcible argument to the prospective assurer than any consideration of working expenses. It is Bonuses not easy to make any fair comparison between the various offices because of discrepancies in their ages and the conditions of their policies. But the following table shows the annual rates of bonus declared on a whole life policy of $£_{I}$ oo where the assurance was affected at the age of 20 and the policy had been in force for I5 years: (Australasian Life Assurance Societies, I905.)

Citizens Life

\section{Revisionary}

A. M. $P$.

National Mutual .

New Zealand

Colonial Mutual.
$£_{3}:$ bonus

2: I8: 0

I: I8: 8

I : $3: 4$

o: 12: 5

o: 8:
Cash
value

I7: 9

o: I7: 7

o: 10: 6

0: 7: I

o: 3: 6

o: $2: 8$ 
In the above table it will be seen that the State Office takes fourth place. It is on the question of bonuses that the State Office is likely to suffer most in competition with other offices, unless it can make a better showing in the future than it has done in the past. The Department, of course, does not acknowledge inferiority to any company in any respect. The Commissioner, in his Report for 1907 , says:

"The progress of the Department has been well maintained through the operations of the year. The new business returns have again improved, and there have been satisfactory increases in both the interest and premium income. The mortality experience has continued to be favourable, and an interim actuarial valuation of the liabilities under policies in force shows that the profit resulting from the year's business has been highly satisfactory, auguring well for the bonus-distribution due at the end of next year." (Annual Report of the Government Insurance Commissioner, I907; Actuary's Report, 1906.)

Perhaps the following table will give a more concise and accurate comparison on the question of premiums and bonus rates than can be gathered from the foregoing details, since it shows the original sum that can be assured for a premium of $£$ Io, and the amounts to which it will accumulate by addition of bonuses. The figures are for the age of 20 at entry; for other ages the results are very similar.

Age, 20. Premium of $£_{I}$ o per annum.

\begin{tabular}{rrrrrr} 
Year & A. M. P. & \multicolumn{2}{c}{ Citizens. National Mutual. Government. Mutual Life. } \\
o & $£_{534}$ & $£_{532}$ & $£_{544}$ & $£_{562}$ & $£_{540}$ \\
5 & 587 & 569 & 587 & 590 & 56 I \\
I0 & 667 & 6 I & 636 & 6 I 8 & 578 \\
I 5 & 742 & 698 & 685 & $65 \mathrm{I}$ & 592 \\
20 & 822 & - & 739 & 688 & 6 I0 \\
25 & 902 & - & 816 & 724 & 631 \\
30 & 977 & - & - & 762 & 643
\end{tabular}

The percentage of policies which lapse forms one of Lapses the weakest features of the State Office. A writer in the Sydney Bulletin, who has usually a good word for the State Office, writing in 1907, says: 
"A worse trouble by far with the Maoriland office is the lapse rate. Maoriland on account of its prosperity ought to show few forfeitures. Yet the State Office has a disheartening record. . . While 19.7 per cent. of the total discontinuances in the A. M. P. Office were due to forfeiture of policies, 47 per cent. in the Maoriland State Office were due to that cause. Or, in another way, while 0.6 per cent. of the amount insured with the A. M. P. lapsed last year, no less than 3.9 per cent. or more than six times more in proportion lapsed in the State Office. No doubt the A. M. P. office figures are particularly good, but the State office figures should, from the very nature of the office, be particularly good. Possibly the office suffers because it is confined to the State. If a man moves from one part of Australia to another or from Maoriland to Australia, the A. M. P. office does not lose him. But if a small policy holder moves out of Maoriland, the chances are that with no local office to pay the premium to he will drop out. That may be the explanation. At any rate, the matter calls for enquiry. For it is a tremendous drag on an office to pursue new business and then lose it after a year or two."

And the writer ends up by estimating that it costs the State Office over two years' premiums to secure a policy holder.

The figures quoted appear to be correct, but removals could account for only a small proportion of the total lapses. A much more likely suggestion has been made. Other leading offices furnish their canvassers and agents with a horse and trap which enables them to go into the country and get business from well-to-do farmers. The State agents are not so furnished and accordingly confine their efforts to the towns where competition is keener and the average policy much smaller.

Again, the State Office pays its agents full commission on what are known as "quarterly cases," that is, cases which pay their premiums by quarterly instalments. If these cases lapse after one, two or three quarters have been paid, the State Office debits the agent with the instalments unpaid, but if the agent leaves the State Office, the refund cannot be collected and the State Office loses part of the commission.

Whatever the causes may be it remains clear that the 
lapse rate is far too high and that steps should have been taken long ago to check it.

In I89I the State Office showed the lowest interest earnings of the nine Australasian offices then doing business, but in 1900 it stood third on Investments the list. In the interval the rate of interest fell steadily, but the decrease in the case of the State Office was less than that of any private office, because it had not so far to fall. The earnings of the State Office fell from 4.95 per cent. in 1896 to 4.5 I per cent. in 1905.

The funds of the State Office, like those of the private offices, are invested chiefly in mortgages on land, and in government and municipal debentures. But it is a curious fact that the State Office has now a larger percentage of its investments in mortgage loans than any private office except one. It might be thought that the State Office would show an undue inclination to put the assurance funds into State loans, but since 1902 the tendency has been the other way. The probable explanation is that a higher rate of interest is required to allow of higher bonuses. In this matter the State Office occupies a delicate position, for the Government may be tempted to sacrifice the interests of the policy-holders to its need for money. For example, it was alleged that this was done in 1898 when the Government gave the State Insurance Department 3 per cent. debentures at par in exchange for debentures to the value of $£ 625,000$, the bulk of which had carried interest at 4 I-2 per cent. and the balance at 4 per cent. The transaction occasioned considerable outcry at the time and indicates a danger to which the State Office is peculiarly liable.

The conclusion which emerges seems clear that, while the State Office proved fairly successful in its earlier 
years, its present position is unsatisfactory. It is difficult to see why the Office has not held The State Office its own better in recent years. The fact not doing its that it has behind it all the prestige of Share of New the State, that its contracts are guaran- Business

teed by the State, that all new entrants into the civil service must insure with it, and that its agents have the same monetary incentive to exertion as the agents of private companies, should be sufficient, one would think, to keep the office in the front rank. But, as we have seen, its bonuses are outclassed by several competitors; its lapse rate is abnormally high; and it is not getting its proper share of new business.

The explanation usually offered by State officials is that the office is confined to New Zealand and that its range is too limited. They point to the fact that even so powerful a company as the A. M. P. has found it necessary in recent years to go outside of Australasia for new business. But it seems doubtful if this explanation is well grounded. If the State office cannot hold its business in New Zealand, it will not do so elsewhere.

Another factor which may account in a slight degree for the slow progress of the State office is the large number of superannuation schemes which are being instituted in connection with all branches of the Civil Service. These are compulsory, and the contributions which they call for may, perhaps, render it difficult for civil servants to insure for large amounts with the State office.

Failing any other explanation, it can only be concluded that there is no one sufficiently interested to instill the necessary enthusiasm into the officers and agents. True, the agents are paid by Tendency to results, but that is no guarantee that their work will be carried on with the enthusiasm and 


\section{I66 STATE SOCIALISM IN NEW ZEALAND}

rivalry that characterizes men engaged in building up a private office. Perhaps a sense of patriotism should lead people to insure in the State office without the efforts of canvassers. If they did so, the State office could easily outdistance its rivals. But failing this, the only way is for the Department to display the same energy, economy and efficiency as private offices. Unless it does so, and does it quickly, there will be an increasing tendency to stagnation, and the opponents of State enterprise will be furnished with another illustration, and that in a field which seems more adapted for successful State enterprise than almost any other. 


\section{CHAPTER X}

\section{STATE FIRE INSURANCE}

The State Life Insurance Department was begun at a time when there were no vested interests to oppose its introduction, but the State Fire Insurance Office was established only in 1903 after many years of intermittent agitation in favor of it and a ceaseless opposi-

Agitation for the Establishment of State Fire Insurance tion on the part of the private companies. In I896, a meeting of delegates representing various Fire Insurance Protection Associations passed the following resolution:

"That fire insurance for the protection of buildings, stock and effects is a necessity of private and commercial life: that the business of fire insurance in the past has been profitable to the companies trading in New Zealand: that insurance from the powerful combination of the insurance companies has become a monopoly and that the insured are expected to accept whatever tariff the combined companies choose to impose: that life insurance by the State has been a success, and the delegates present, representing large interests, are unanimously of opinion that the time has arrived for the establishment of a State Fire Insurance Department: that it should be on the mutual principle and should be compulsory so far as all buildings are concerned and optional for stock and effects: that the Government be requested to at once give its earnest consideration to the promotion of such a scheme." (Quoted in Parliamentary Debates, vol. 124, p. 570.)

In the same year a bill was introduced into Parliament to provide for State Fire Insurance, but it failed to pass. By 1902 the agitation had become strong enough to lead the Government to introduce a bill framed on the lines of the resolution just quoted. The numerous insurance companies trading in New Zealand became alarmed, and started a vigorous campaign against the proposal, both in Parliament and in the press. The Bill 
was referred to a committee which collected a large amount of conflicting information on the question of the fairness of the existing rates.

In the following year a new bill was introduced from which the compulsory clauses of the previous bill

Arguments in Favour of the Proposal

were eliminated. The chief argument advanced in Parliament in support of this bill may be summarized as follows: (Parliamentary Debates, vol. I20, pp. 229-257 ; Parsons, Story of New Zealand, pp. 57I-579).

I. It was alleged that huge profits were being made by the 27 private companies doing business in New Zealand, and their large dividends and yearly additions to reserves were quoted in support of this contention.

2. The success of the State Life Insurance Department, the Public Trust Office, and other State undertakings was insisted on as showing the feasibility of the new proposal.

3. The private companies were stated to have formed a ring, and to be in the habit of laying down arbitrary and unreasonable conditions.

4. Assuming that experience showed that business could not be profitably carried on at lower rates than those imposed by the private companies, it would be an easy matter for the State to close up its Department at the end of the year, since no distant obligations would have been incurred, as in life insurance, and no heavy capital expenditure, as in coal mining.

5. Many of the companies were owned by foreign capitalists, and the country was being annually drained of huge sums which were paid in dividends to foreign shareholders. A State Fire Insurance Office, it was held, would keep this wealth in the country.

6. The State could offer better security than any private company. 
The chief arguments advanced in reply were these:

I. The private companies were not making undue profits, and it was misleading to quote their dividends, as most of their profits were earned abroad. The rates in New Zealand were the result of many years' experience, and any reduction would involve carrying on

Arguments against the Proposal business at a loss. Statistics showed that while in some years the companies made 15 or 20 per cent., in others they had heavy losses, and their average profits over a series of years were between 4 and 5 per cent.

2. It was misleading to rely on the analogy of life insurance, in which risks and liabilities could be measured with fine accuracy. "There is nothing more risky or more highly speculative under the sun than fire insurance and no enterprise more unsuited for a Government to undertake."

3. It was unfair for the State to pit the country's patronage, influence and public funds against private enterprises, which had done all the pioneering work and had made the business a success.

4. The experience of Switzerland had shown that the compulsory insurance of buildings and their contents was the backbone of the scheme. The compulsory clauses having been eliminated from the bill, the only justification for it was gone.

5. Political influence and the characteristic inefficiency of governmental management would prevent any chance of success.

6. The State office would not be able to get reinsurance from any other office, and the risk was too great for it to carry alone.

7. The area of operation would be too small, as a population of less than $1,000,000$ did not afford sufficient 
scope for the working out of averages. Also, New Zealand was one of the most dangerous fields known to insurance companies.

The opposition to the bill by the Underwriters' Association was all the more keen because it was recog-

An Insurance Trust alleged to Exist nised that if the Government of New Zealand were successful in the fire insurance business, the governments of other countries might follow suit. A strong section of the press championed the cause of the underwriters, and did its best to show that profits were not unduly high for so speculative a business, and that if profits did appear high it was because of the necessity of building up strong reserves. The private insurance companies pointed with pride to the fact that they were modelled after the pattern of the world-famous English companies whose stability had been demonstrated in a remarkable manner in settling losses after great fires in Chicago, Jamaica and elsewhere. However, in spite of all opposition, the bill passed into law with the approval of the people as a whole, who were convinced that the private companies had formed a ring and were exploiting the community.

The State Fire Insurance Act, 1903, provides for the establishment of an office to be administered by a general manager appointed by the Governor, and for the necessary staff. There is a Board The Act of 1903 of Management consisting of the General Manager, the Colonial Treasurer, the Government Insurance Commissioner, and two other persons (not being members of the Civil Service), appointed by the Governor. To provide capital the Treasurer may, by authority of the Governor in Council, raise from time to time such sums as he thinks fit not exceeding 
$£_{100,000}$ in all. There is provision for raising additional capital, not exceeding $£ 20,000$ at a time, to carry on business until the pleasure of Parliament is signified. The rate of interest on capital raised must not exceed 4 per cent. The General Manager must, at the expiry of each triennial period, pay over to the Public Trustee one half of the net profits to the credit of a State Fire Insurance Sinking Fund account. As soon as sufficient is paid into this account to meet the debentures at maturity, subsequent accretions are to be paid into a reserve fund. Triennially, one half of the net surplus profits goes to the reserve fund and the other half is to be divided in bonuses amongst actual insurers in proportion to premiums paid (The State Fire Insurance Act, I903).

On January 4, 1905, the State Office began business with premiums Io per cent. less than those accepted by private offices. A conference of under- Competition bewriters was immediately called and re- tween the State prisals followed. The private companies and the Private reduced trade risks by ro per cent., as Companies the State Office had done, and reduced the rates on such risks as dwelling houses and furniture by 33 I-3 per cent. The State Office, in its turn, came into line by making the same reductions. (State Insurance in New Zealand, by W. P. Reeves, North American Review, January, I906.)

At the same time the private offices resolved to boycott the State Office by declining to take reinsurance from or to give reinsurance to the State Office. They even went so far as to refuse to accept any risk on which the State Office held a line. In brief, they did their best to put the State Office out of business.

This attitude on the part of the private companies was 


\section{STATE SOCIALISM IN NEW ZEALAND}

designated by Mr. Seddon as " monstrous and immoral," and in September, 1905, he despatched the General Manager to England to arrange for reinsurance. Arrangements were made with Lloyd's for reinsurance of the State risks, and by this means the attempted boycott was checkmated.

Early in 1906 the private offices abandoned their boycott so far as to allow each other to accept risks on which the State Office held a line, and also to consent to the State Office taking a risk on which they themselves held lines, but they still declined to give or receive reinsurance.

The Government, on its part, as a step toward securing further business, had by a circular issued in

Unfair Competition of the Government
June, 1905, notified all borrowers from the Public Trust Office, the Advances to Settlers Office, and all other State lending Departments, that they must place their fire insurance risks with the State Office. Under the ordinary covenants in mortgage deeds the lender has the right to dictate in what office the borrower shall insure, but in practice the right is seldom exercised.

The private companies cried out against this attempt to coerce insurers, and pointed out that if the State insisted on its right to a monopoly of fire insurance in the State lending Departments, it would easily reach the next stage of charging monopoly premiums.

The financial aspect of the State Fire Insurance Office for the three years for which figures are available may be Financial Condition of the State Office briefly stated as follows: (State Fire Insurance Office, Annual Reports for the years ending December 3I, I905, I906 and I907.) 
STATE FIRE INSURANCE
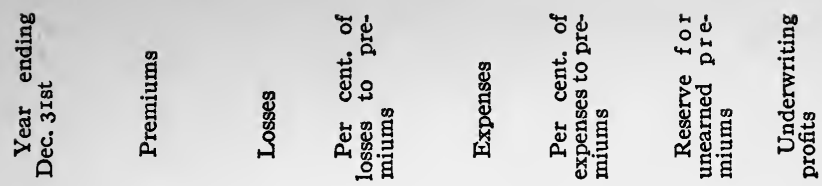

I905

$£_{13,127} £_{2,418}$

I $8.4 \mathrm{I}$

$£_{4,860}$

$44.6 I$

7,776

37. I I

I907

23, 195

I $2,701 \quad 55.19$

$8,989 \quad 38.83$

$£_{4,376 \quad £_{48} \mathrm{I}}$

$2,612 \quad 190$

$744 \quad 196$

There are three points which will attract attention in this table:

First,- The amount set aside as a reserve for unearned premiums stands at less than 33 I-3 per cent., whereas the best English practice requires 40 per cent., and in the United States, where losses by fire are proportionately greater than in England but less than in New Zealand, the customary reserve is not less than $5^{0}$ per cent. of the annual premiums. This represents what is considered a safe margin to cover the possible contingency of a company's closing down and requiring to buy cover for its clients in another office for the remainder of their premium year. In 1908 the reserve was raised to 40 per cent.

Second,- The working expenses of a well-conducted fire insurance office should not exceed from 35 to 37 per cent. of its premium income, whereas the State Office has an average expenditure of 40 per cent.

Third,- By far the most serious aspect of the table is the small amount of underwriting profit and the nominal amount of the reserves. Indeed, if in the years 1906 and 1907 the Net Loss in 1908 State Office has been charged the annual license of $£ 200$ payable by private offices its balance sheet would have shown a loss. Finally, in the year 1908, the year's operations resulted in a loss of $£_{5,707}$, mainly due to bush fires and to the Christchurch 
conflagration (Evening Post, October 9, 1909.) In the year 1909 there was a net profit of $£ 2,699$. (Annual Report of the State Fire Insurance Office, 1910).

The insufficiency of the scale of premiums was recognized by the General Manager early in the history of the Office. In his annual report for 1906

The Premium too Low

he said:

"Though the prevailing rates of premium presumably are highly satisfactory to the insuring public, in view of the fact that they are very much below what they were prior to the advent of the State Office, nevertheless experience has shown that they are lower than they should be."

Again, in the Report for 1908, the General Manager said :

"The rates of premium during the above years have remained the same, but the existing rates have not proved sufficiently high to enable a strong reserve to be built up after the payment of expenses of management, fire losses, etc." (Year-Bo ok, I909, p. 694.)

Commenting on the losses of 1908 , the Hon. George Fowlds, Minister in charge of the State Fire Office, said:

What are

Reasonable

Premiums?

"Experience had shown that the ruling rates were disastrous from an insurance point of view. Last year the State Office made a considerable loss on the business which was done, and all the companies doing business in New Zealand were badly hit, so that it was quite clear that the existing rates could not be maintained without heavy losses all round. He did not think it would be justifiable to run the State Fire Insurance as a burden on the general taxpayers of the Dominion, and the only way to avoid that would be to get a reasonable increase in the rates to meet the risk they had to run. The functions of the State Office must be to see that the rates were kept within reasonable bounds." (Evening Post, July 3, I909.)

This was the first frank admission of a fact which had been recognized for some time. The General Manager had always glossed it over with a reference to the enormous saving in premiums to the insuring public. In the Report for 1907 he says:

"The insuring public, however, have reaped the benefit of the reduced rates, seeing same approximately amount to $£ 450$, ooo for the past three years." 
On the other hand, it was stated that the insurance companies had lost $£_{159,354}$ in the year I908, and £254,956 since the State Office was opened (Evening Post, July 3, 1909), without reckoning the profits which they might have earned in that time. Obviously, it was a case of " robbing Peter to pay Paul."

Had the State Office been doing the whole of the fire insurance business of the Dominion its losses would have been at least as great as the combined losses of the State Office and the companies, and the advantage to the public vs. the Insuring would have been nothing. It may be that the insuring public is almost co-extensive with the tax-paying public, but tax-payers as such should pay taxes, and insurers as such should pay premiums, and any mixing up of the obligations can only work injury to all concerned. Insurance should not be sold for less than it costs any more than any other service or commodity.

As might be expected, insurance people look upon the activities of the State Office with disgust and alarm. A leading Australian Insurance Journal says:

Inadequate

"Operations are being carried on at such Reserves ruinous rates that the Department is unable to maintain a reserve of more than 30 per cent. for the unexpired risk, a percentage which is recognized by all underwriters as being far below the safety margin. Should the Department get caught in a large fire, a heavy loss will have to be shown, there being no reserve for exceptional losses at all. If the New Zealand State Fire Department is going to pay its way in the future, it will have to revert to the rates obtainable before its advent, and when that point is reached the object of having the Department at all will be obviated." (The Trustees and Investors Review, Sydney, August 26, I907.)

Referring to the companies' losses for 1908, another authority says:

"These figures are lamentable. The losses have occurred and are still occurring, and companies cannot be expected to provide a surplus out of which they shall all be paid. It is a great pity, but 


\section{I76 STATE SOCIALISM IN NEW ZEALAND}

nevertheless true, that the fire waste in the Dominion is excessive. This should not be the case in a young and prosperous country like this, but there is no disputing the facts." (Evening Post, July 3, 1909.)

Notwithstanding their losses in the Dominion, the great New Zealand companies have continued to pay dividends because of the profits on their The Companies oversea business. For example, the New pay Dividends Zealand Company, which paid an enormous sum to American insurers after the San Francisco disaster, declared a dividend of 5 per cent. upon its paid-up capital for the half-year ending May 3 I, 1907, and showed a reserve of $£_{390,000}$ (Sixtyninth Report, New Zealand Insurance Company, Limited, February 12, 1908.) Commenting upon this report, the New Zealand Herald said:

"Our great local insurance corporations, The Companies' of which the New Zealand Company is a type, Reserves

have extended their business far and wide, and under progressive but cautious management have built up reserves which give them a status second to none in the confidence of the insuring public. . . The accumulation of reserves, the making of such preparations as will enable heavy blows to be endured without loss of strength and without undue pressure upon shareholders, is an essential feature of sound insurance management. . . A State Fire Office ought surely to be self-supporting, unless the private companies are to be driven out of business and fire insurance carried on upon philanthropic lines as a new form of State socialism which we may fairly term revolutionary and dangerous. This is certainly not intended; but since to make the State Fire Office or any other fire office self-supporting on its New Zealand business, rates must be raised to somewhat as they were before it was instituted, we may fairly ask what is the good of a State Fire Office at all?" (New Zealand Herald, Auckland, February I3, 1908.)

It is quite likely that the rates which prevailed before 1905 were not at all exorbitant, in view of the extraordinary fire waste in New Fire Waste High Zealand, which is considerably larger than that in the United States, which, in its turn, is much greater than the loss by fire in European countries. In this respect the State Life Office 
has a great advantage over the State Fire Office, since the death rate of New Zealand is one of the lowest in the world, while the fire waste is one of the highest. The "Insurance and Banking Record" stated in 1908 that the insurance loss in the Dominion for the previous five years averaged about 7 shillings per head against a little over 5 shillings in the United States. The Inspector of Fire Brigades estimates the total loss in New Zealand, insured and uninsured, at i Is: $81 / 2 d$. per head, as compared with Ios. per head in the United States. Such high averages as these may be due to the large proportion of wooden buildings in New Zealand and the United States, to defective construction and inadequate protection against the spread of fires. (Evening Post, November 23, 1909.)

Again, it is well known that parts of New Zealand are in the earthquake zone, and a repetition of the San Francisco disaster of 1906 might occur in Wellington or other cities at any Danger of time. Dr. Mackintosh Bell, Director of Earthquakes the Geological Survey, recently said in a public lecture: "I have no hesitation in saying that if the earthquake of I855 were repeated to-morrow, very few of these fine buildings, certainly none on the made ground along the edge of the harbour, would be left standing." (Evening Post, August 9, 1900.) In view of such a contingency, the insurance companies are surely well advised in accumulating large reserves, and the State Fire Office would do well to follow their example.

It must be remembered, however, that, except for the first reduction of Io per cent., the unprofitable rates that have prevailed since the advent of the State Office were dictated by the private offices, which have only themUnwise Action of Companies selves to blame for a large part of their losses. 
The State Office was obliged to meet the competitive rates of the companies or go out of business, in which case the companies would have reimposed their old scale of rates. The only way to satisfy the public that the competitive rates were too low was to go on until a substantial loss resulted. This has now occurred, and the public will acquiesce with a better grace in an increased scale of premiums.

Even if the rates are raised to the extent necessary to prevent a loss, it may still be desirable to maintain the State Office as a safeguard against Premiums to imposition. Its existence may still be be Increased warranted if it can be shown that honest business can be done at less than the scale of rates in force before the State Office entered the field. Certainly, the companies could do business at any rates profitable to the State Office, although their profits might be reduced. But if the old rates were sound and reasonable, then the whole scheme of State Fire Insurance has been a costly blunder.

The present writers do not profess to be sufficiently versed in matters of insurance to sit in judgment on either the State Office or the private companies. But if the old rates were fair, it is clear that the practice of founding legislation such as this upon public opinion and party prejudice, without the advice of competent experts, should be abandoned, lest it should lead to further unprofitable ventures on the part of the State and more serious losses on the part of private investors.

The one point which may be safely emphasized in connection with almost all forms of governmental enterprise, is that the State ought not to sell services or goods to one portion of the community at less than cost price and make up the deficit by taxes upon the whole community. 


\section{CHAPTER XI}

\section{OLD AGE PENSIONS}

Among the causes that led to the passing of the Old Age Pension law in so young and prosperous a country as New Zealand, emphasis has commonly been laid on the uncertainties of Poverty in pioneer life, on the rapid alternation New Zealand between prosperity and depression in countries chiefly engaged in growing raw materials for Europe, and on the alleged desire of a socialistic democracy to equalize wealth and to relieve the individual of the responsibility of taking care of himself by transferring the burden to the State. But to some extent, at least, the poverty which the pension law presupposes appears to have been caused by the defective system of charitable aid, which has often been a source of poverty instead of a cure for it.

The first statutory recognition of the right of the indigent to claim relief from the community was contained in "The Hospital and Charitable Institutions Act, I885," although practically the right had been yielded a long time be-

The Right to Relief fore that by the provincial governments in the first instance, and, later, by the general Government. (Parliamentary Debates, vol. 53, p. 46I.)

Under the Act of 1885 , re-enacted in 1908 , the Dominion is divided into thirty-five hospital districts, each presided over by an elective board designated the "Hospital and Charit- Charitable Aid able Aid Board." All the charitable 
institutions in the District are vested in this Board, except those incorporated as "separate institutions," which have their own powers of internal management and look to the Board merely for their funds. It is the duty of the Board to raise sufficient money to take charge of the institutions remaining unincorporated, and to supplement the funds of the incorporated institutions. The revenues of the Boards are derived from endowment vested in the Boards, or set apart for the benefit of particular institutions, from voluntary contributions, grants from local authorities, and subsidies from the general Government. On the demand of the Board in any district, the various local bodies in the district levy special rates as their contributions to the Hospital and Charitable Aid Fund. The general Government grants subsidies of Ios. for every $£_{I}$ of bequests, $£_{I}: 4 s$. for every $£_{\text {I }}$ of voluntary contributions, and $£_{\text {I }}$ for every $£_{I}$ received from any local authority. (Year-Book, I909, p. 293.)

As a result of this somewhat intricate enactment the management of poor relief has been wholly localized, but

Localized Management the expense has been only partially localized. It was hoped that by making the governmental subsidy vary with the amount of local contributions, the springs of private charity would not be dried up, or, if they were, that the local rates would take their place. But these hopes were not realized, and in the end the greater part of the burden of poor relief was thrown upon the State, while the responsibility for administering it remained with the local authorities.

Three years after the passing of the Act, Dr. Duncan MacGregor, the Inspector of Hospitals and Charitable institutions, reported as follows:- 
"The chief difficulty to be got over in the working of all our charitable institutions is the impossibility of getting the taxpayers of the large towns where the most lavish charity is dispensed to take the least trouble or even to try to hinder the wholesale pauperization that is going on. So long as the State gives money out of the Consolidated Fund and allows the towns to tax the country, what hope is there that this problem will be seriously faced? One of the chief aims of the existing Act was to leave nothing undone to encourage the voluntary contributions for charitable purposes that so honourably distinguished some districts, but unfortunately here, as elsewhere, a poor law dries up the springs of private charity." (Appendix to the Journals, 1889, H. 3.)

Dealing in 1894 with a special effort made by private subscriptions to cope with a formidable increase in unemployment, Dr. MacGregor says:

"This is a new departure of the most hopeful augury that a time is coming very soon when no money will be raised by the Central Government to be expended in outdoor relief by local bodies, and when all outdoor relief is paid for out of direct local taxation. It is, in my opinion, the only plan by which this young country can escape disaster due to investing a large part of the consolidated revenue in the permanent degradation of the people."

\section{Again, in I895, he writes:}

"Having its roots mainly in the undesirable immigrants who were sent here during the ascendant years of our great public works policy, we have here and now among us a growing mass of persons who are not helpable in any effective way and our method of dealing with them is simply destructive of the Commonwealth." (Report, I895, H. 22, Appendices.)

In $\mathrm{I} 897$, Dr. MacGregor reiterates his previous statements and cites with approval the presidential address at the American Congress of Charities and Corrections, in which the problem of outdoor relief is attacked in one respect by

Drastic Reform proposing to " cut off the entail of heredtary pauperism and crime and insanity and idiocy in a very large degree by keeping defectives in institutions which resemble heaven in at least one particular, because there is neither marrying nor giving in marriage in them." On this Dr. MacGregor says: 


\section{I82 STATE SOCIALISM IN NEW ZEALAND}

" Outdoor relief is as catching as smallpox and just as deadly. In $\mathrm{r} 890$ a bill on exactly these lines was introduced into our Parliament. Two years ago it was recast leaving out the cardinal principle of imprisonment for all able-bodied loafers who would not work. The reason for leaving out this keystone of the arch was that public opinion was not ripe for such a drastic step."

\section{In the same year the Assistant Inspector, Mrs. Neill,} says:

"I am more than ever convinced that the existing system of outdoor relief encourages a cancerous growth of pauperism and many another social evil. Is the Charitable Aid Board deputed by the State and ratepayers to relieve destitution or to alleviate poverty? If the former we may hope to minimize pauperism and help upward honest struggling distress; if the latter we may as well try to fill a sieve with water."

That the authorities quoted were not alone in their opinions, although their persistent efforts toward reform Opinions of Mr. of the system of charitable aid have been Seddon and Dr. Valentine

ignored, can easily be shown. Mr. Seddon himself, in introducing his Old Age Pensions Bill in $\mathbf{1} 896$, said:

"Is there a member of the House who will tell us that our present laws dealing with charitable aid are working satisfactorily? I say that class of legislation has been the bane of our Colony. We are producing, as it were, a class of paupers, and yet who do not feel that in receiving aid under legislation they are degenerating and holding an inferior position. And yet that system is costing this Colony no less than $£ 90,000$ a year." (Parliamentary Debates, vol. 95, p. 625.)

\section{Dr. T. H. A. Valentine, the present Inspector-General} of Hospitals, says in his report for 1908:

"I may yet be able to convince the people of the Dominion that an indiscriminate doling out of charitable aid must, in the long run, have a bad effect on the country at large. It is the duty of those responsible to call attention to this, and to try to convince the controlling authorities that no recipient of charitable aid should be better placed as regards the necessaries and comforts of life than the struggling working man. Authorities on the subject agree that the only way to prevent abuse in the administration of out-door relief is to throw the whole cost on the local rates, and with that end in view the Government subsidy for out-door relief should be withdrawn." 
These statements are very instructive, not only as pointing to an important agency in fostering poverty, but as calling attention to the extreme difficulty of the problem of poor relief, and as showing that the poor law system should have been reformed, if it could have been reformed, before the Government proceeded to build up a system of old age pensions. (Parliamentary Debates, vol. 100, p. 325.)

The Pension Law was passed in 1898 and was amended in 1900, 1901, 1902, 1905, 1908 and 1909, and the following is a brief sketch of the law as it now stands.

The qualifications required of an apThe Old Age Pensions Act plicant for a pension may be divided into three groups.

I. Qualifications as to age and length of residence. The applicant must be 65 years of age, and must have resided continuously in New Zealand for the twenty-five years preceding his application. But four years' absence. is allowed provided that twelve months' residence occurred immediately before the appllication and a total residence of twenty-five years is established.

2. Qualifications designed to exclude the undeserving. The applicant is disqualified from receiving a pension if he has been imprisoned during the preceding twelve years for four months or on four occasions for an offence punishable by twelve months' imprisonment; or if dur-, ing the twenty-five years preceding his application he has been imprisoned for five years; or if during the preceding twelve years he has deserted his wife and children; or if he has not during the twelve months preceding his application lived a sober and reputable life.

3. Qualification as to poverty.

The applicant's yearly income must not amount to 


\section{I84 STATE SOCIALISM IN NEW ZEALAND}

over $£ 60(\$ 300)$, and his accumulated property must not be $£ 260(\$ 1,300)$ or over.

The conditions imposed to exclude the undeserving represent an attempt to impose a moral standard which must always be unsatisfactory but which External Stand- it is difficult to replace by anything betard of Desert ter. If the principle of granting pensions is once admitted, an arbitrary external standard of conduct is the only practicable test that can be imposed. The preamble of the Act reads as follows:

"Whereas it is equitable that deserving colonists who during the prime of life have helped to bear the public burdens of the Colony by the payment of taxes, and to open up its resources by their labour and skill, should receive from the Colony a pension in their old age." (The Old-age Pensions Act, I898.)

Commenting on the discrepancy between the preamble and the Act, Mr. A. R. Atkinson said:

"The preamble notwithstanding, there is no guarantee that a pensioner shall have done any work for the Colony or contributed one iota of honest labour and skill towards opening up its resources or helped in any way whatever to bear the burden of taxation, nor, on the contrary, is there any guarantee that he shall not have obstructed or neutralised the labour and skill of others and made himself a burden to the taxpayer and a pest to society all his life. Crime during the prime of life does not disqualify; poverty and idleness at 65 are necessary to qualify; and practically the only thing to disqualify is the industry and care which at that age have accumulated the sum of $£_{540}$ or are still competent to earn more than $£_{34}$ a year. It is no exaggeration to say that demerit and not merit is what the Bill fosters and favours."

The only answer that can be made to this criticism is that unless we content ourselves with some such rough and ready tests, we must either allow the merits of each applicant to be gauged by the "length of the chancellor's foot," or abandon all attempts to exclude the unworthy and make the pension universal.

Much greater difficulties present themselves in considering the exclusion of those whose income or property 
exceed the minimum mentioned in the Act. The full pension of $£ 26$ a year is reducible by $£_{I}$ for every $£$ I of income over $£ 34$. Thus, Standard of when the applicant's income reaches $£ 60$ the right to a pension is lost. Income is money or profits derived from any source, and includes the cost of board and lodgings up to $£ 26$, but not sick allowance or funeral benefits paid by a friendly society. In the original Bill of 1896 , personal earnings were excluded from the definition of income, but it was pointed out that under such circumstances a Supreme Court Judge with an income of $£_{\text {I }, 500}$ a year, provided he had no property, could apply for a pension. Accordingly, in the Act, personal earnings were included in income.

As to property, a deduction of $£_{I}$ is made from the pension for every $£$ Io of accumulated property. Thus, when the property reaches $£ 260$ the right to a pension ceases. The reason given for this limit is that for the sum of $£ 260$ a person aged 65 can buy an annuity to keep him for the rest of his life.

It is frequently argued that a man's home, whatever its value, so long as it was not used to produce an income, should be exempted in estimating accu- Proposed mulated property. Accordingly, a strong Exemption of effort has been made on several occasions the Applicant's to have this exemption made. The pro- Home posal was at first resisted by Mr. Seddon, but in 1905 he yielded so far as to allow a deduction of $£_{15}$ o when any part of the property of an applicant consisted of property on which he permanently resided, if such property produced no income. Further than this he refused to go, saying, "if you do away entirely with the property disqualification you might just as well have the universal pension." (Parliamentary Debates, vol. I32, p. 365.) 
On October 21, I909, a large deputation of members of Parliament waited on the Premier and urged that the applicant's home, of whatever value, should be exempted. Mr. T. E. Taylor, who took a keen interest in moulding the original Bill, said:

"Whatever the value of the home was, so long as it was only the result of their taste and their thrift, it should not be a disadvantage to them. At present the better class of Colonists had to see less thrifty pensioners getting the full amount, while they, because they had improved their homes, were not eligible to receive the full amount." (Evening Post, October 21, 1909.)

The Premier, while expressing sympathy with the proposal, stated that if a limit of only $£ 650$ on a home were conceded, the annual cost of the pensions would be increased by $£_{50}$,ooo, which was more than the Government could afford at that time.

The proposal to exempt homes serves to illustrate the impossibility of arriving at any logical or consistent basis for pensions short of a universal pension. The owner of a home worth $£ 650$ is not necessarily more thrifty than a man who has the same value invested in some other way, and, if homes were exempted, the owners of other property would presently claim an equal exemption. It is impossible to arrive at a system designed to help the poor which will at the same time reward others for not being poor. The law cannot recognize both thrift and unthrift at the same time, unless pensions are granted to rich and poor alike.

A point that was brought out by Sir Joseph Ward, in reply to the deputation, was that a good many pen-

Some Pensioners have Wellto-do Relatives sioners had well-to-do relatives, on whom the burden of their support ought to fall. No doubt there is a large number of aged persons who are willing to accept a pension, but who would refuse to receive charitable aid, as 
they are not ordinary paupers and their relatives would support them if they had to do so. The Evening Post says:

"A State which relieves them of the liability by undertaking the work itself not only adds quite unnecessarily to its own burden, but at the same time encourages a far meaner vice than unthrift." (Evening Post, Wellington, October 22, 1909.)

A curious feature of the law is the total exclusion of persons of certain races from the right to a pension, although they otherwise comply with all the requirements. It is natural, of course, that aliens should be excluded,

Asiatics

Excluded but Chinese and other Asiatics are disqualified, even though they may have been naturalized. Their exclusion seems a matter of course to the people of New Zealand and Australia, who are possessed of an unconquerable antipathy to all Asiatics. But if the racial prejudice is excusable, it should be carried to its logical conclusion, and Asiatics should not be allowed to become naturalized. Under both English and New Zealand law it is declared that a naturalized subject "shall be entitled to all political and other rights, powers and privileges, and be subject to all obligations to which a natural born British subject is entitled and subject." Therefore, while an Asiatic is permitted to take out letters of naturalization he is denied the rights which such letters expressly confer. If such a case occurred in the United States, the law would doubtless be held to be unconstitutional.

The New Zealand system of Old Age Pensions has been extravagantly praised as the acme of humanitarian legislation, and unsparingly condemned as a demoralizing form of charitable aid.

But neither of these extreme views can be regarded 
as correct. It is erroneous to describe the system as a Pensions not a mere extension of outdoor poor relief. Mere Extension In so far as the granting of the annuity of Charitable is made dependent on qualifications Aid designed to limit it to deserving persons, the payment may properly be called a pension rather than a form of charitable aid.

"This pension recognizes that the man who has kept his head above water till he is 65 years of age, who is a man of good character, who has not been a drunkard nor a criminal, should be supported as of right in his old age, and should not have to come before a body of citizens sitting as a Charitable Aid Board to pass judgment on him as to whether he is a deserving person or not." (Parliamentary Debates, vol. Ioo, p. 62.)

On the other hand, in so far as the payment is made by reason of the applicant's need, and not as a return for premiums paid or services rendered, it is truly described as a form of charitable aid. The recent British Act makes a bolder attempt to exclude the undeserving, since an applicant is disqualified

" if he has habitually failed to work according to his ability, opportunity and need, for the maintenance of himself and those dependent upon him." (Report of the Massachusetts Commission on Old Age Pensions, Boston, I910, p. 94.)

One of the criticisms usually offered, in respect to all legislation of the kind under consideration, is that a legislature elected under universal sufConcessions made from Time to Time

frage will be unable to resist the demands that will be continually made for further concessions and greater expenditure. The amendments made in the Old Age Pensions Act since I 898 seem to offer some support to this criticism. The following are some of the changes that have been made since I898:

I. Original amount of pension, $£_{1} 8$. Increased in 1905 to $£ 26$. 
2. Income allowed in $\mathbf{I} 898$ without disqualification, $£ 52$. Increased in 1900 to $£ 60$.

3. Amount of joint income (with pension added) required to disqualify a married couple, $£_{78}$. Increased in 1900 to $£ 90$.

4. The property and income of husband and wife was at first assessed separately. Since I90o their property and income is estimated jointly and equally divided.

5. In 1905 the deduction allowed from property on account of a home was increased from $£_{50}$ to $£_{15}$.

6. By the Act of 1898 all investigations of claims were to be made in public. By the Act of 1905 these investigations may now be heard in private.

7. By the Act of 1898 two years' absence was allowed in twenty-five years. By the Amending Act of 1900 four years absence was allowed, provided total residence reached twenty-five years.

8. By the Act of 1898 the applicant must not have deserted his wife and children at any time. By an amendment in 1902 the words "at any time " were struck out and "during the past twelve years" substituted.

9. By the Act of 1898 the applicant must for the preceding five years have led a sober and reputable life. In 1908 this period was reduced to one year. This alteration was made to allow pensioners thrice convicted of drunkenness to apply again for their pension at the end of twelve months. As the law now stands, a Magistrate may suspend the pension for a period not exceeding six months as a punishment for the first conviction for drunkenness; for the second conviction he must suspend it for a period exceeding six months but not exceeding twelve months; if satisfied that the pensioner is a habitual drunkard, the Magistrate must cancel the pension. 
10. By the Act of 1908 anyone owning sufficient property to disqualify him under the Act of 1908 was allowed to remove the disqualification by purchasing an annuity of about $£_{34}$, which would still allow him to draw the full pension of $£ 26$.

I I. In 1908 the Magistrate was authorized to regard an applicant's income as " the amount he would probably earn during the ensuing twelve months" instead of the amount of his income for the preceding twelve months.

In reference to the amendment which allows pension claims to be heard in private, it is interesting to note that the Registrar includes this, with Claims now the five amendments first quoted, as heard in Private one of the causes which have helped to bring about an enlarged annual expenditure. (Registrar's Annual Report, 1906.) Writing on this point in 1902 , before the amendment had been made, Mr. Reeves said:

"Seeing that 15,000 claims have been granted, either in whole or in part, it does not look as though many persons with a fair claim have been afraid to make it. And the outcry, against secrecy, had any been attempted, would assuredly have been great and just." (State Experiments, vol. 2, p. 256.)

While the Bill of 1898 was under debate, some members advocated a contributory scheme involving the principle of compulsion, as in the GerContributory man plan. They put forward figures Plan Rejected to show that a weekly payment of 6 pence during his working life would secure to a workingman a competence at the age of 65. Various other compulsory schemes were suggested based on the pri.rciple of governmental aid supplementing individual contributions. So far back as 1884 Sir Harry Atkinson had unsuccessfully advocated a contributory scheme. Mr. Seddon held 
that such a scheme was impracticable and effectively stated the chief objections to it. A system which might work well in a country like Germany where there was relative permanency of employment, would be likely to fail in a young country like New Zealand, where employment was relatively intermittent and it would be inconvenient or impossible for employers and workers to make the necessary weekly contributions. And certainly, it would be impossible to employ an army of collectors under military control. Mr. J. Hutcheson put the argument in a nutshell when he said:

"I say to those who propose compulsory state insurance that before they can carry it out they must first be prepared to find for every one permanent employment at a living wage and something over, and then garnish their wages for the amount of the pension premium." (Parliamentary Debates, vol. I0o, p. 72.)

The argument of Mr. Lloyd George against establishing a contributory pension in Great Britain gives a new view of this question. He said:

"As long as you have taxes upon commodities which are consumed practically by every family in the country, there is no such thing as a non-contributory scheme. If you tax tea and coffee and partly sugar, beer and tobacco, you hit everybody one way or another." (Report of the Massachusetts Commission on Old Age Pensions, Boston, 1910, p. 94.)

The only other system which has been seriously discussed is that of a universal pension, and this has been favoured by a large number of people as the only logical way of escape from the inconsistencies of the existing sys- sive tem. In 1905, the Leader of the Opposition wished to move an amendment in favour of a universal pension, but was prevented by the Standing Orders of the House.

In opposition to this proposal Mr. Seddon quoted the 


\section{STATE SOCIALISM IN NEW ZEALAND}

following figures to show the annual cost of a pension

Cost of Pensions to all those who were qualified by age and length of residence without any other restriction:

Year ending

March 31, r906

March 3I, I907

March 3I, I908

March 3I, I909

March 3I, I9IO
Estimated number qualified by age and residence

35,332
36,747
38,524
40,075
42,178

Total cost at $\mathfrak{f}_{26}$ per annum

$\mathcal{£}_{918,632}$

955,422

I, 001,624

$\mathrm{I}, 04 \mathrm{I}, 950$

$1,096,628$

Commenting on the figures he said:

"Are you prepared to add another half million by way of taxation for the sole purpose of paying a universal pension? My own view is that the moment you attempt to levy additional taxation for the old age pension that moment you break down the entire pensions scheme and it is simply the beginning of the end." (Parliamentary Debates, vol. I32, p. 365., vol. I45., p. 762.)

The financial difficulty seems to be the only one that has restrained Parliament from granting universal pensions, although it would surely be absurd and unjust to levy taxes on the whole community for the purpose of paying pensions to people who do not need them.

The following table shows the number of pensioners for every year since I900, together with the total amount paid and the cost per head of the population:

\begin{tabular}{|c|c|c|c|c|c|}
\hline $\begin{array}{l}\text { Year ending } \\
\text { March } 31\end{array}$ & Pensioners & Amount & \multicolumn{3}{|c|}{$\begin{array}{l}\text { Cost per head of } \\
\text { population }\end{array}$} \\
\hline I900 & I I , 285 & $£_{\text {I } 57,342}$ & $4 s$. & $\mathbf{I} d$ & $(\$ 0.98)$ \\
\hline I90I & I 2,405 & I 97,292 & 5 & I & \\
\hline 1902 & 12,776 & 207,468 & 5 & 3 & \\
\hline 1903 & 12,481 & 210,140 & 5 & 2 & \\
\hline 1904 & 11,926 & 203,164 & 4 & ro & \\
\hline 1905 & I I, 770 & I95,475 & 4 & 6 & \\
\hline 1906 & 12,582 & 254,367 & 5 & 8 & \\
\hline 1907 & I 3,257 & 314, I 84 & 6 & IO & \\
\hline 1908 & I 3,569 & 325,199 & 6 & II & \\
\hline r909 & 14,396 & 336,760 & 6 & I I & $(\$ 1.66)$ \\
\hline
\end{tabular}

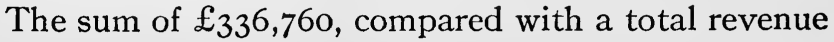


of over $£ 9,000,000$, seems trifling, but it should be remembered that in the latter amount are included the receipts from railways and other investments which are not available for purposes of general expenditure. The expenditure on pensions should be compared with the total revenue from taxation, which was $£_{4,377,76 \mathrm{I}}$ in the year 1909. The Old Age Pensions, then, absorb about 8 per cent. of the revenue from taxation. This does not seem to be a heavy burden for a prosperous country like New Zealand, and the people of the Dominion regard it with equanimity.

It was expected that the establishment of Old Age Pensions would reduce the amount spent on charitable aid, but such has not been the case. The Hon. Dr. Findlay said Expenditure on recently in the Upper House:

"The increase in our population from I 894 to 1908 was from 683 , I I I to 945,063 , and the increase in hospital and charitable-aid expenditure for the same period was from $£_{177 \text {,- }}$ 724 to $£_{349,62 I}$. In other words, the increase in hospital and charitable-aid is advancing much more rapidly than our increase of population, so that per capita the burden is steadily increasing and will go on increasing. That impresses upon us that we have got to exercise, as soon as possible and as firmly as possible, every degree of economy, care and prudence on the administration of this large fund." (Parliamentary Debates, vol. I48, p. 486, Dec. I, I909.)

No doubt, as Mr. Anstey said in the same debate, the work of charitable-aid is carried on with far greater efficiency than formerly, so that the comparison with former years is not quite fair, and yet it is diasppointing to find that so large an expenditure on pensions should have no effect in reducing the burden of charitable aid. It should be noted that the amount spent per capita in outdoor relief has slightly diminished, so that the increase in total expenditure must have been due to improvements in the hospitals. (Report of the Massachusetts Commission on Old Age Pensions, Boston, I910, p. 106.) 


\section{I94 STATE SOCIALISM IN NEW ZEALAND}

One result of the establishment of pensions and of the increasing expenditure on poor relief out of the public funds, has been a marked decline in Voluntary Con- relative proportion of funds derived from
tributions fall Off voluntary contributions, notwithstanding the great increase in private wealth. People who are compelled to pay taxes for charitable purposes seem disinclined to make voluntary contributions as well. Dr. Findlay says:

"It is, perhaps, not a very satisfactory state of things, but it is true, that the contributions to this class of poor relief from voluntary sources have steadily declined in New Zealand in proportion to the total amount required. It was at one time one ninth of the whole amount; now it is, I believe, less than one twelfth. . The present Chief Justice had an opportunity, when dealing with the subject matter in the Senate the year before last, to point to the fact that in twenty-one of the large deceased estates left in New Zealand - estates of over $£$ I $00,000(\$ 500,000)$, and some of them were a good many hundreds of thousands - not one brass farthing was left to any public institution, whether it be for charitable purposes or for education. This matter of impressing their legal obligation on the people has been in a large measure forced on the Government by the fact that the wealthy sources which should most freely contribute, were not as helpful as they generally have been elsewhere." (Parliamentary Debates, vol. I48, p. 486.)

The number of pensioners and the total expenditure is certain to increase from year to year. The scope of the An Increasing Act was widened by the Amendment of Proportion of I908, with the result that the number of Old People accept Pensions pensioners increased by 827 in the year ending March 3I, I909, as compared with an increase of only $3 \mathbf{I} 2$ in the previous year. In 1908 it was estimated that 32 per cent. of the European population eligible by age and residence were receiving pensions, but in 1909 the number was about 34 per cent. of those eligible. In case the percentage rises to 40 per cent., the expenditure in the year I9I3, as estimated by Sir Joseph Ward, will be $£ 463,000$.

(Parliamentary 
Debates, vol. I45, p. 750.) If Parliament should decide to exempt the value of homes from the computation of property, the expenditure would be increased by about

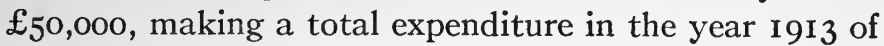
over $£_{500,000}(\$ 2,500,000)$.

But it is likely that the number of pensioners will increase because of an increase in the relative number of old people. In I900, Professor Segar, of the University College, Auckland, pointed out that New Zealand, owing to Number of Old its recent settlement, had a larger proportion of young people and a smaller proportion of old people than such countries as England and France, but that the proportion of old people was increasing from year to year. Professor Segar says:

"If New Zealand had permanently an annual number of births equal to about 20,000 , the total population would reach ultimately about $\mathrm{I}, \mathrm{I} 00,000$, and of these no less than $\mathrm{I} 20,000$, or $\mathrm{I} 0.9$ per cent. of the whole, would be old people eligible in respect of age for old age pensions, that is, the number of old age pensioners might be expected to increase about fivefold while the whole population increased only about 30 or 40 per cent.

"But not only have we a larger proportionate increase in the cost of pensions to expect from this source, but we must expect in the future a larger percentage of the old people to receive old age pensions than have hitherto taken advantage of them, and this for several reasons. The majority of old people of the present day arrived here in the early day of the Colony and it must be expected for several reasons that of these a greater proportion will have succeeded in attaining easy circumstances and providing for old age than will generally succeed in so doing among a population living through times of more normal conditions. Again, there will be gradually a smaller and smaller number of old people disinclined to accept pensions because of their savouring of charity and poor relief, and a smaller and smaller number who will be disqualified on account of not having lived the requisite number of years in the Colony. Moreover, when commercial depression once more returns to us, many now barely provided for will feel the need of help." (Transactions of the New Zealand Institute, I90o, vol. 33.)

Professor Segar's criticism is not directed against the principle of old age pensions, but merely against the 


\section{STATE SOCIALISM IN NEW ZEALAND}

fallacy of supposing that the cost would increase only The Relative in proportion to the population and the Number of the wealth of the people. However, the Aged Poor likely wealth of New Zealand has increased durto Increase ing the past ten years, more rapidly than the population, and the cost of old age pensions has not yet become a heavy burden. Mr. Laurenson said in the House, when the Amendment of 1908 was under discussion:

"Those of us who have taken an interest in politics will remember the chorus of criticism that was directed against the measure when it was passed, and how it was denounced by every one who believed in what he called " individualism." Yet we have seen it grow more and more popular, until now not one reasonable man raises his voice against the principle of old-age pensions for the deserving poor. And when we remember that it is only sixty years ago since Ruskin prophesied that the day would yet come in civilized communities when it would be looked upon as much a matter of course that a man who had served his country with his spade should draw a pension as the man who had served his country with his sword, we begin to realize how quickly public opinion changes." (Parliamentary Debates, vol. 145, p. 760 .) 


\section{CHAPTER XII}

\section{THE PUBLIC SERVICE}

A Cabinet Minister recently stated that no less than I30,000 persons in the Dominion, out of a total population of about I,000,000, were directly dependent on the State. (The Hon. J. A. Millar at Wellington, July 5, 1909.) The following is an approximate estimate of

A Large Number of Public Servants the number of employees in the different departments: (The writers are indebted to the Hon. J. A. Millar for these figures, who says: "It must be clearly understood that the figures are approximate."

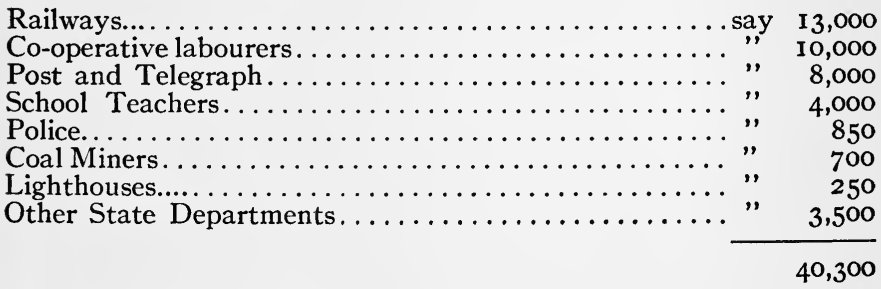

If to these State employees we add the old-age pensioners, numbering about 14,000 , we have a total of 54,000 persons in the pay of the State, most of whom are adults and voters, and they, with their dependents, allowing only $2 \mathrm{I}-2$ persons to a family, would number at least 130,000, as in Mr. Millar's estimate. In other words, one eighth of the people of New Zealand are directly dependent on the State.

Out of the total number of State employees, a large number, including the co-operative labourers and many 
casual employees in various departments, cannot be regarded as belonging to the public service in the narrower sense of that word. Indeed, a distinction is sometimes drawn between the public service and the civil service, the latter being a smaller circle than the former and composed of persons who have entered the service through the door of competitive examination and who may expect permanent employment and promotion in the regular way.

In the early days, strict regulation as to appointments to the Service was not felt to be necessary, for, until the abolition of the provinces in 1876 , the Appointment to number of persons in the employ of the the Service

general Government was small. The

Civil Service Act of I 866 expressly provided that the entrance examination was not to be competitive, and as there was no fixed standard it soon fell into disuse and appointments were practically made at the pleasure of the Ministry.

A new chapter was opened in 1886 by the passing of the Civil Service Reform Act, of which the cardinal feature was a system of competitive Competitive examinations as the door to the Civil Examinations Service. This was contrary to the wishes of the Premier, Sir Robert Stout, who brought in the Bill, for he held that competitive examinations would discriminate in favor of town children because of their special educational advantages. Sir Robert Stout therefore recommended a pass examination, not too severe, with the right of nomination by members of Parliament in rotation so as to draw the Service from all parts of the Colony and to free it from party control. He quoted the system of admission by nomination to the United States Navy, which, in his 
opinion, secured the finest naval officers in the world. (Parliamentary Debates, vol. 55, p. 367 ; Political Address by the Hon. Sir Robert Stout, at Marton, March II, I887.)

This proposal passed the Lower House but was rejected by the members of the Upper House, apparently because they were given no right of nomination, and an amendment embodying a system of competitive examinations was inserted which was grudgingly accepted by the Lower House and has remained an essential part of the Civil Service Act until the present day. (Civil Service Amendment, 1908.) However, it was obvious that in some cases experts would be required who could not be got from the ranks; therefore a clause was inserted dispensing with examinations as regards

"persons skilled in medicine, law, navigation, science, technical art, or the management of live stock, or in naval or military matters or extra clerks." (Civil Service Reform Act, 1886.)

Before many years had passed it was discovered that the list of exemptions could be made elastic enough to restore political patronage to an astonishing degree, by a liberal interpretation of the terms "skilled persons" and

Political

Patronage

" extra clerks." The "extra clerks " contemplated by the Act were census and valuation clerks to be appointed temporarily for special emergencies, but from 1890 onwards, extra clerks were appointed and retained in such numbers as to largely defeat the intention of the Act. In $1906 \mathrm{Mr}$. Seddon stated that between $\mathrm{I} 893$ and I904, 548 cadets had been appointed to the Civil Service and 439 experts. They came to be spoken of in Parliament and elsewhere by the curious name of "permanent temporary clerks." They were distinct, on the one hand, from casual clerks, inasmuch as they remained in permanent employment without any permanent appoint- 
ment; and, on the other hand, from regular Civil Servants, inasmuch as they had none of the statutory rights of Civil Servants, such as superannuation and leave of absence.

The presence of these clerks in the Service was a constant source of friction and complaints were repeated-

"Permanent

Temporary

Clerks"

ly heard in Parliament to the effect that they were filling positions which should be occupied by qualified cadets. Indeed, in some departments they exceeded the number of the regular clerks. Year after year the Government was urged to purge the Service of these "permanent temporary Clerks," but gradually time lent colour to their claims, and in 1899 it was proposed to give them the full legal status as members of the Civil Service.

Finally, in 1907 , when provision was made for the classification of the Service, it was enacted that all persons who had then been continuously employed for the five preceding years should be deemed to be officers permanently appointed. No temporary clerk disqualified for permanent appointment was thereafter to be continued in employment for more than six months, nor was he to be temporarily reappointed to the Service within six months after ceasing to be employed therein; but the Governor was authorised, if he considered the public interest required it, to make a temporary appointment by order in Council for more than six months. (Public Service Classification Act, 1907.)

Under the present law appointments to the Civil Service are made in order of merit from Order of Merit the most successful candidates at the annual examination. In 1908 over 2,000 candidates sat for the Civil Service Junior Exam- 
ination, many of whom had no intention of entering the Civil Service but took the examination as a test of their ability, as a credential in seeking private employment, or for other purposes.

The Civil Service examination is not required for admission to either of the two largest branches of the Public Service, namely, the Railways Departments Department and the Post and Telegraph not requiring Department. Applications for admis- the Civil Service sion to these are made in accordance with Examination departmental regulations. No person is eligible for employment in the Railways if two or more members of his family are already in the service, and there is a similar regulation in the Post and Telegraph Department. Selected applicants for the Railways must pass a medical test, and are deemed to be on probation for the first three years. Certain educational qualifications are required, varying from the "third standard " of the State schools to the passing of the Civil Service Junior examination or the University Matriculation examination.

The securing of appointments to these departments affords some scope for the use of political patronage by Members of Parliament. Until recently, the Minister for Railways made appointments to most of the lower branches of the Service on the recommendation of the Member for the District. It is understood, however, that the present Minister, Mr. Millar, has discarded this plan, and makes appointments according to priority of application without regard to politics.

To Members who wish to devote themselves to larger political questions the numberless applications by seekers of Government Office Seekers billets are very vexatious. Mr. A. W. Rutherford, formerly Member for Hurunui, said: 
"The applications I receive from candidates for the Public Service are the worry of my life; men, women and children all seem to want to get into Government billets."

On the other hand, Members have been known to boast to their constituents of their success in securing billets. The extent to which political influence is sought is well summed up by Mr. F. E. Baume, K.C., Member for Auckland East, who said recently in Parliament:

"Members of Parliament are to a large extent labour agents; there is not one of us who is not supposed to possess some influence with the Government and who is not expected to use that influence in behalf of persons seeking Government billets."

The question of promotion presents one of the most difficult problems of the Public Service, and, with the increasing number of departments and officers, the problem becomes more Promotion difficult from year to year. On the one hand there is the danger of promotion by favoritism or political influence; or on the other the equal or greater danger of promotion by seniority, which some scoffers have called " promotion according to senility."

The latest attempt to solve this insolvable problem is the Public Service Classification Act, 1907, a comprehensive measure providing for the grading of all departments not already classiClassification fied, with the exception of one or two minor Services. The Act sets up a Public Classification Board consisting of a Minister of the Crown and such permanent heads of departments, not exceeding ten in number, as the Governor from time to time appoints. The Board is to prepare a scheme of classification for all positions, fixing maximum and minimum salaries, with annual increments, which is to be submitted to Parliament for approval. The right of 
each officer to an increase of pay is to be dependent each year on a certificate of efficiency and good conduct from his departmental head.

No classification has yet been made in accordance with this Act; partly because of the delay occasioned by the recent retrenchments, partly because the Board has found the undertaking one of enormous magnitude and extreme difficulty and has not yet reached any satisfactory results.

The Prime Minister, Sir Joseph Ward, who was the first to grapple with the classification of the Railway Service and who has done a great deal for the Public Service generally, fully realizes the dangers of political influence. When the Classification Bill was before Parliament he said:

“ I am prepared to put in a clause making it illegal for any Member of Parliament to make any recommendation for appointment or promotion of Civil Servants. I think it will be better for the country, better for the service, and very much better for Members of Parliament.

The chief advantages of classification are that it reduces the possibilities of political influence and wire pulling, and makes it possible for officials of reasonable ability to rise gradually and steadily to important and reAdvantages of Classification munerative positions in the Public Service. It secures, too, a certain kind of efficiency, the efficiency that comes from long service and much experience, which is frequently sadly lacking in public servants in the United States. Incidentally, it relieves Ministers and Members from the importunities of office-seekers, and tends toward the purification of politics.

But the disadvantages of classification are very great. The more thorough and exact the classifi- 


\section{STATE SOCIALISM IN NEW ZEALAND}

cation becomes, the more certainly does it tend to proDisadvantages motion by seniority rather than by effiof Classification ciency or ability. This tendency has been strongly manifested in the departments already classified, and it is certain that such a system fails to secure the most efficient men for the most responsible positions. Moreover, it largely takes away from the heads of departments and sub-departments the power of appointment and dismissal, a power very likely to be misused, but which, in private business at least, makes for individual efficiency and the harmonious working together of individuals toward a common end.

To fall back on classification is largely a confession of failure. The annual certificate of "efficiency and good conduct" must in practice be of a A Confession merely negative value, as indicating of Failure that the officer has done nothing to prevent his promotion rather than that he has shown peculiar aptitude or exceptional intelligence. Besides, the subordinate who wishes to secure the favour of his chief does not always find it advisable to show extraordinary ability, which is more likely to make him a rival than a friend. On the other hand, the chief who finds inefficiency in his staff, or other evils that should be eradicated, is much inclined to let things alone, for the sake of peace, and because he knows the difficulty of making any change for the better. When promotion is made otherwise than by seniority, the officers passed over often insist that political influence has been at work; and the result is that such promotions are very seldom made. And yet, a classified Civil Service is surely better than a "spoils system" such as it common in the United States, where officials are not only appointed for 
political reasons but are dismissed when the opposing party comes into power. In brief, the spoilsman is inefficient because his appointment and promotion depend upon political services; and the civil servant is inefficient because his appointment and promotion depend upon an artificial classification. Speaking in Kaitangata in 1908, Sir Joseph Ward said that

" classification was a very difficult matter to deal with, but after all it had to be recognized that it was very much better for the Service as a whole than the old rule, that very often existed, of kissing going by favouritism."

It is probable that the chief defect of the classification scheme consists in trying to classify above a certain salary. A prominent member of the Classification Board said to the writer: "No attempt should be made to classify men receiving more than $£_{250}(\$ 1,250)$ a year. You cannot classify brains, and all attempts to do so must end in failure and injustice."

The personnel of the Public Service in New Zealand does not change with the accession of a new party to power, as has often happened after a presidential election in the United States, The Tenure of and as regularly occurs after the election Office Secure of a new party in most of the states of the Union. In this respect the best traditions of the British Civil Service have always obtained, and as a result each departmental head renders loyal and faithful service to the political chief who happens for the time being to control his department. The "spoils" system has never flourished in New Zealand, and although political influence has had a good deal to do with appointment and preferment, the tenure of office is secure to all members of reasonable ability, no matter what their political creed, provided that they do not take an active part in politics. 
Public opinion appears to be growing in favour of non-political control of appointments and of preferment in the Public Service. The chief motive A Public Service that influenced Parliament in 1887 in Board Suggested establishing the Railway Commission was to get rid of politics in the management of the railways. But the Commission was abolished in 1894 and the railways reverted to political control. Prior to the general election of 1899 the Progressive Liberal Association of Canterbury issued a manifesto in which, referring to the Civil Service, it said:

"The great dissatisfaction which has arisen over the manner of making appointments to the Public Service calls for some change. Appointments should be governed by the principles of fitness and priority of application. The intercession of a member of Parliament should have no weight whatever. To rid the country of this debasing influence, a Public Service Board should be appointed for a term of years and the Board should have full control of the Public Service."

In I904, Mr. A. L. Herdman, M. H. R., brought in a bill for the purpose of setting up a non-political Board to control the Service, but the bill was Opposed by the blocked by the Government on technical Government grounds. In 1905, Mr. Herdman tried to secure a vote of the House in favour of such a Board, but his motion was lost by 43 votes to 23. He complained of the "vicious system of patronage and political nepotism that was demoralizing the service." He quoted figures to show that New South Wales had effected large savings by the work of a non-political board, and that the whole service had been rendered thoroughly efficient and imbued with a fine spirit. On the other hand, Sir Joseph Ward has always hotly resisted the proposal, on the ground that Parliament would thereby lose control of expenditure and be replaced by an " uncontrollable autocracy." He claims that the true reform is classification of the Service, with the retention of 
parliamentary control. Mr. Herdman again brought up the question in 1909, but without making any headway beyond having the matter discussed. As a rule, the Opposition is in favour of reform in the Service, while the party in power tries to keep all the patronage and influence it can.

The question is a very difficult one and much is to be said on both sides. Non-political boards exist in New South Wales, Victoria and in the Public Service of the Commonwealth, and there Danger of Desseems to be no serious proposal to revert potism to political control. And yet, the Sydney Bulletin regards the establishment of such boards as a confession of failure and an admission that the people are unable to govern, since to save themselves from their representatives they must put all State departments under " a possibly competent and possibly incapable despot." (The Bulletin, August 20, 1903.)

On first impression it would seem, from the large number constantly seeking admission, that the conditions of employment in the Public Service must be pleasanter or more profitable than those prevailing in private employment. Entrants to the Public Service

Government Billets in

Demand usually start at a higher wage than beginners in private employment; and, while there are no great prizes to be won, a fairly good living is assured; salaries are regularly paid; annual rises in salary are automatic; holiday and sick leave are provided for by regulations; and the superannuation allowance is always pleasantly in prospect at the end of the journey. The Service appeals strongly to many people, especially those who shrink from the strenuous conflict of private business, with its risks of failure, and are glad to exchange the chance of a great 


\section{STATE SOCIALISM IN NEW ZEALAND}

reward for the security of a protected life. Besides, the Public Service offer an honourable career, very attractive to young people of family and education, who do not like farming, look down upon "trade," and find the "learned professions" overcrowded.

And yet, there are some very serious disadvantages connected with the Service, of which four seem to call for special notice. The first of these is the Service:- the unsatisfactory system of promotion, Promotion which, while it may please those who have political influence and people of mediocre ability who are promoted by seniority, is discouraging to young men of special talent who are eager to receive the reward of their work and dislike waiting for an opportunity to step into " dead men's shoes."

The second disadvantage is the necessity for periodical retrenchment due to the fact that the State tends to overstaff its departments in times of Periodical prosperity. There have been three notRetrenchment able bouts of retrenchment; one in 1880 , another in 1887 , and the most recent in 1908. The retrenchment of 1880 followed the period of inflation of the seventies; when, under Vogel's policy of borrowing for immigration and public works, vast sums of money were spent and the Public Service greatly increased in numbers. Parliament, in a fit of economy, passed a drastic resolution: "That a reduction be made of not less than io per cent. from all salaries, pay and wages, except officers of the legislature. That the Government make as large a reduction in the staff of officers as can be effected by amalgamation and reorganization of offices, and that such public offices as are not indispensable to the efficient conduct of public business should be abolished." 
In 1887 the Government was again embarrassed, and Sir Harry Atkinson was called on to rehabilitate the finances of the Colony. In his Budget of 1887 he said:

"Our chief difficulties have arisen in a great measure from a too lavish expenditure, more especially of borrowed money; that must be stopped, and our first duty therefore is to apply the pruning knife with an unsparing hand."

In pursuance of this policy, Sir Harry Atkinson placed the railways under a non-political Commission; he reduced the allowance of the Governor, the Premier and the other Cabinet Ministers; and reduced the cost of the Civil Service, which then stood at over $£_{\mathrm{I}, 000,000}$ a year, by nearly one fourth.

As soon as prosperity returned, the Colony entered upon another period of public borrowing and expenditure; the Public Service again increased unduly in numbers; and, in 1908 , another period of retrenchment was inaugurated. The fact that Sir Joseph Ward announced that he intended to effect economies in the Public Service amounting to a quarter of a million annually, "without in any way impairing its efficiency," shows clearly that the Service had grown beyond all requirements and was again to be sacrificed for the sins of politicians. The total number of " retrenched " officials at this time was 940. The Government set aside certain blocks of land for their benefit, but with what success civil servants may be transformed into farmers remains to be seen. (Budget, I909, p. xvi.) In his speech at Winton on May 5, I910, Sir Joseph Ward announced that the enforced retrenchment had resulted in a saving of $£ 98,970$; and that, because of return of prosperity, no further retrenchment would be necessary. (Otago Daily Times, May 6, I910.) 
The third special disadvantage of the Service arises from the fact that in certain occupations the State is the Public Servants only employer of labour. Many years Dependent on the State

ago a strike took place among the telegraph operators in New Zealand; they were dismissed from the Service and found it impossible to get work elsewhere. They went to Australia in search of work, but the New Zealand Government had anticipated their movements and requested the Australian Governments to refuse to assist them. The case is perhaps an isolated one and not of much practical importance, but it shows at least the possibility of the State's establishing a tyranny from which certain classes of labourers might find it difficult to escape. Up to the present, however, the civil servants have not shown any marked subservience toward their employer, the State; on the contrary, they are sometimes criticised as being too independent of the State and of the people whom they are supposed to serve.

Far more serious than this is the disadvantage imposed upon members of the Public Service in that they are not

Public Servants in Politics allowed to take an active part in politics.

Civil Service Regulation 22 reads as follows:

"In order that officers of all ranks may be enabled to render loyal and efficient service to Government, it is necessary, and they are hereby expressly enjoined not to take any part in political affairs otherwise than by recording their votes at elections; and every violation of this regulation will be forthwith visited with such penalty as the circumstances of the case shall appear to require."

The rule in the Railways Department, published in April, 1907, is very similar:

"Members are not to take an active part in politics beyond recording their vote."

The case of J. A. McCullough, a tinsmith employed in the Railway workshops at Addington, well illustrates 
the working of this rule. The conduct complained of was that Mr. McCullough was the mover of a motion hostile to the Ward Government, which was carried at a meeting of the Independent Political Labour League. He was dismissed in September, 1907, but afterwards notified that if he gave a written undertaking to comply with the regulations he would be allowed to resume duty. This he refused to do, on the ground that he had been permitted for many years to take an active part in politics unmolested and unwarned by the Department. He said :

"I look upon the exercise of my political rights as a sacred duty I owe to my children and my country. This restriction is, in my opinion, besides being undemocratic and illiberal, entirely unnecessary and uncalled for. If enforced it will tend to make the public servants of the country a crawlsome and opinionless body of men and women, who will lose their courage to express their views because of this restriction."

The question was brought before Parliament and occasioned an animated debate. On the side of $\mathrm{Mr}$. McCullough it was stated that he did not know of the rule, that he had received no warning, that public servants had frequently been active supporters of the Government and had not been reprimanded for their activity, that public servants ought to have all the rights of citizens, and that capable men among them were needed in the political life of the Dominion. Mr. Barclay went so far as to propose a bill of a single clause to the effect that:

"From and after the date of the passing of this Act no person in the employ of the Dominion of New Zealand in any of the public services shall be dismissed or discharged only for the expression of his or her views or opinions on political affairs."

The bill was not taken seriously, even by the mover himself.

The opinion of the House was almost unanimously 
in favour of the Government's action, although there was some criticism of the laxity of the The McCullough Government in enforcing the rule in the Case past. Mr. Okey said:

"This matter of public servants taking an interest in political matters has been going on for some time-in fact, in the past it has been encouraged by the previous Government to such an extent that it was felt that a man could not get work under the Government unless he supported them."

Mr. Alison said:

"I have contested two parliamentary elections, and in each contest found quite an array of public servants working against me. - . I I know it has been the custom of a proportion - I do not say a very large proportion. perhaps - of the people employed by the State to take a very active part in connection with politics. If this sort of thing is going to be allowed, we shall very soon get to the position, referred to this afternoon, in some of the American states, where, when a party in power goes out of office, all the prominent officials go with them."

Naturally, the members of the Opposition were glad to have the Government to take a strong stand against allowing the public servants to meddle in politics.

Sir Joseph Ward, in defending the Government's action, said that Mr. McCullough must have known

Servants must

not rule the

Country
The Public

that he was acting contrary to the rules of the Public Service, and that in several other cases public servants had been dismissed for the same offence, although they had not been opposing the Government. He said:

"It is impossible to allow the impression to go abroad over New Zealand that the Public Service, because of the fear or weakness of the Government, is going to be allowed to rule New Zealand. I am persuaded that the people of this country would not allow a system of that sort to be permitted by any Government." (Parliamentary Debates, vol. I4I, pp. 233-235, 265-287.)

The people of New Zealand, like those of Australia, fully appreciate the danger of allowing the members of 
the public service, now very numerous, to take an active part in politics. It is thought, and with good reason, that they would throw the weight of their influence on the side of the party that would do the most for them in the way of paying higher salaries, granting larger retiring allowances and making other concessions contrary to the interests and wishes of the rest of the people. This would be a new form of exploitation, the exploitation of those outside the public service by those within, an abuse which it would be very hard to eradicate, in case a Government allied itself with the public servants and used its power in.other directions in an unscrupulous way.

So the people of New Zealand, most of whom are not public servants, regard themselves as the employers of the public servants; and, while allowing them to vote, partially disfranchise them by forbidding them to take an active part in politics on one side or the other. The general opinion on this question is well expressed by the Evening Post:

"If the Government does not rule the Civil Service, then the Civil Service will rule the Government." (Evening Post, October 3, 1907.)

In reading this pregnant sentence one is strongly reminded of the opinion freque..tly expressed in the United States, to the effect that if the Government does not rule the trusts the trusts will rule the Government.

The issue involved in the McCullough incident must come up for decision with increasing frequency as the Public Service expands in numbers and influence. That public servants should be kept out of politics seems to be highly desirable, but that it will be possible to do State Socialism and the Public Service this when they constitute a majority of the people is by no means likely. If the functions of Government are to go 
on increasing, the power of the Public Service also will increase, and sooner or later, for good or ill, the country will be governed by the Public Service.

As to Mr. McCullough, he was dismissed from the Railway Service; but in November, 1907, he was elected by the workers' unions to be workers' representative on the Arbitration Court. (Annual Report of the Department of Labour, 1908.)

There are many other interesting questions connected with the Public Service, which it is impossible to consider within the limits of a single chapter. By far the most important of these is Efficiency the question of efficiency, which is at the same time the most difficult to answer. Efficiency may be defined as the securing of a maximum of utility at a minimum of cost. On the side of utility, the Public Service is seen to be doing a great deal of work for the public benefit and to be doing it well. On the side of cost, it appears as though the expenditure, per unit of result, were higher than the corresponding expenditure in large private undertakings. True, the Government can, and does, compete with private enterprise in the selling of insurance, the lending of money, the mining of coal, and the like; but, after supplying commodities and services at a competitive price, little or no profit is left to the Government, while private companies can supply the same things at the same price and yet earn a profit over and above interest on the capital employed. It may be said that the profit which the Government might earn has gone to the employees of the Government in the form of higher wages or other concessions not granted by private employers, but it is not clear that this is the case. It is possible, if not probable, that the profit has been extinguished by a reduction in the amount of 
the product per unit of labour employed. However, the question is one which could not be settled without an exhaustive investigation into the comparative efficiency of public and private employees and in to the true nature and social utility of private profit. There is a tendency toward stagnation in both public and private service; but the financial measuring rod can be more easily applied to private employees," and the periodical "shaking-up" which they receive gives them a great advantage over public servants. The introduction of modern methods of cost accounting would do much to increase the efficiency of the Public Service.

As to the personnel of the Service, the writers have formed the opinion that it would be hard to find a more capable body of public servants in any country in the world. The standard The Personnel attained by the Service is high; the of the Service bureaucratic spirit is not pronounced; there is little or no "graft"; and the officials keep in touch with public opinion without descending into the arena of partisan politics. If it were possible to do away with political influence in making appointments, and if a method of promotion by efficiency rather than seniority could be established, the Public Service of New Zealand would be almost ideal. 


\section{CHAPTER XIII}

\section{THE ARBITRATION ACT}

With the exception of a few brief intervals of prosperity, times were hard in New Zealand from 1879 to I895. The population of the Colony in-

Industrial Depression creased considerably, but chiefly through an excess of births over deaths rather to an excess of immigration over emigration. From 1885 to 189 I there was an excess of emigration over immigration of about 20,000 . This was the socalled "soup-kitchen period," when wages were low, when there were many unemployed, and when able-bodied men received aid from public and private funds. In I889 it was alleged that sweating existed in Dunedin and elsewhere, especially in the clothing trade, and a Commission of nine members was appointed to investigate the matter. Six of the commissioners found no sweating in the Colony, while a minority of three reported that it existed, "although only to a limited extent." One result of the investigation was the passage of the Factories Act, I89I, designed chiefly for the protection of women and children employed in factories. Another result of this and other causes was the compulsory arbitration law of 1894 , designed chiefly to prevent strikes, but also to encourage organization and improve the conditions of labour.

In the year 1890 occurred the great maritime strike, which began in Australia and soon spread to New Zealand, beginning in August and lasting until the first 


\section{THE ARBITRATION ACT}

week in November. This, the only serious strike that the Colony had ever had, made so profound an impression on the public mind that people were ready to listen to

The Maritime Strike

suggestions looking toward the prevention of such evils. The suggestion of compulsory arbitration came from the side of the labourers, who, beaten in the strike, looked to the State to do for them what they had been unable to do for themselves. (Parliamentary Debates, vol. 78, p. I6r.) The Seamen's Union and other labour organizations took an active part in the political campaign of 1890 ; helped to win victory for the Liberal Party in the election of December 5 ; and strongly supported the labour legislation which followed, including the compulsory arbitration law, the author of which was the Hon. William Pember Reeves, Minister of Labour in the Ballance Government.

It is impossible to say who first suggested compulsory arbitration as a remedy for strikes. The thought must have occurred to many minds during the trying times of 1890. Even before the strike, Mr. J. A. Millar, the secretary of the Seamen's Union and of the Tailoresses' Union, giving evidence before the Sweating Commission, said?

"As to arbitration, my idea is that a competent judge should be appointed by the Government in the same way as the judge of any court, and that he should call evidence on both sides. I mean a permanent judge, who should be paid by the State for the settlement of these disputes; because it is in the interests of the State that no such disputes should exist. I would have this judge assisted by three representatives of each side, who should call evidence, and the decision of the judge should be binding on both parties for a certain time - say, six months. If workmen refuse to obey the court, pressure should be brought to bear upon them by their societies." (Parliamentary Debates, vol. I45, p. I88.)

Later in the year, Mr. W. Downie Stewart, Sr., brought down a bill called the "Strikes and Board of 
Conciliation Bill," based on the voluntary principle. Compulsory arbitration was suggested in committee, but was strongly opposed by Grey and Ballance. (Parliamentary Debates, vol. 78, pp. I 16, I66, 4II.)

But the passage of the compulsory arbitration law of I 894 was due to the enthusiastic efforts of Mr. Reeves, supported by the labour leaders. The Efforts of Mr. Reeves bill was first drafted in I89I, but did not become law until the end of the session of 1894 , after it had been passed three times by the House and rejected twice by the Council because of its compulsory features. The purpose of Mr. Reeves was two-fold. He says:

"What the Act was primarily passed to do was to put an end to the larger and more dangerous class of strikes and lock-outs. The second object of the Act's framer was to set up tribunals to regulate the conditions of labour." (Reeves, "State Experiments in Australia and New Zealand," vol. 2, p. I35. Parliamentary Debates, vol. 79, p. 379; vol. I45, p. 208.)

Mr. Reeves' chief idea was to prevent strikes; and a great deal more was said in Parliament about industrial peace than about the improvement in the conditions of labour which the Act was to bring about; but there can be little doubt that the unionists, without whose help the Act could not have been passed, thought more of the latter than of the former result, and looked upon the Act as an important part of the new legislation for the benefit of the working class. (Parliamentary Debates, vol. 78, p. I85.)

Mr. Reeves considered the compulsory feature essential to the successful working of the law. He thought Compulsion and the Massachusetts system of arbitration Conciliation almost ideal, except that it was voluntary and not compulsory. (Broadhead, "State Regulation of Labour and Labour Disputes in New 
Zealand, p. 8.) In an interesting discussion in the House on September 16, 1892, Sir John Hall strongly attacked the compulsory features of the bill; saying that they were opposed to conciliation, designed to force the workers to join the unions, and should be condemned as class legislation, which would tend, not to the reconciliation of classes but to their estrangement. Mr. John Duthie condemned the bill as a piece of amateur legislation which would have a serious effect in checking enterprise and the investment of capital. Mr. Harkness said that the bill was drafted wholly in the interests of unionism. Mr. James Allen said that the workers would gain nothing by compulsory arbitration. Mr. Fergus accused the advocates of the bill of being demagogues. Some days later, in the Council, Mr. W. Downie Stewart strongly opposed the bill on the ground that it would tend to encourage disputes, that awards would be hard to enforce, and that business affairs were too complicated to admit of a fair decision by any court. In view of later events some of these comments seem quite prophetic. (Parliamentary Debates, vol. 78, pp. I5I-I86, 405-4I6.)

The bill was not adequately considered, either by its friends or its opponents. Mr. Reeves says:

"During the three years and a half in which its fate was in suspense, it neither roused the least enthusiasm nor attracted much attention. Only the trade union leaders studied its provisions, decided to support it and did so without flinching."

Mr. Reeves admitted that it was a piece of experimental legislation. "Frankly," he said, "the bill is but an experiment, but it is an experiment well worth the trying. Try it, and if it fail, repeal it." (Reeves, op. cit., vol. 2, p. 107.) The Minister of Labour had set 
his heart on the bill; it had the support of the Government; and, despite the opposition of a minority representing the business interests of the Colony, it was finally put through, and received the assent of the Governor on August 3I, I 894 .

The Act of I 894 was entitled "An Act to encourage the formation of industrial unions and associations and to facilitate the settlement of industrial disputes by conciliation and arbitration."

By the Amendment of 1898 the words, " to encourage the formation of industrial unions and associations," were left out. The Act came into force on January I, I 895, and the first case was decided toward the end of the year. Mr. Reeves left the Colony in $\mathbf{1} 896$, to become Agent-General for New Zealand in London, afterwards High Commissioner, a post which he resigned in 1908 to become Director of the London School of Economics. Being absent from the Colony, he had little to do with the development of the Act, which was amended almost every year as difficulties arose which the author could not have foreseen. The original Act and the various amendments were united into a Compilation Act in 1905, amended again in the same year, and yet again in 1906. The latest and most important amendment was made in 1908 (Industrial Conciliation and Arbitration Acts Compilation Act, I905; The Industrial Conciliation and Arbitration Amendment Act, 1908.)

The Act as it stood in 1905 has been described so many times that only a brief account of it is here given, to-

The Compilation Act, 1905 gether with some points not usually mentioned. An excellent summary of the Act is given in Broadhead's "State Regulation of Labour in New Zealand," Chapter 3. The Act provides for the registration of industrial 
unions and associations of either employers or workers with the Secretary for Labour. As few as two employers or one firm with two members may form a union; but, in the case of workers, seven are required. ${ }^{\mathbf{I}}$ Associations The effect of registration is to make a union, or an association of unions, a body corporate, and renders both the union and its members subject to the jurisdiction of the Conciliation Board and the Arbitration Court. Any industrial union may apply to the Registrar at any time for the cancellation of its registration, but such cancellation does not relieve the union or any of its members from the obligation of any industrial agreement or award in force at the time, nor from any penalty or liability. The cancellation of registration on the part of an industrial union of workers removes it from the jurisdiction of the Board and the Court; but employers cannot thus escape. Arbitration, then, is in a sense voluntary for the workers but compulsory for the employers.

The Colony is divided into eight industrial districts in each of which there is a Clerk of Awards, appointed by the Governor. In every industrial district there is a Board of Conciliation for the settlement of disputes arising

Industrial

Districts within the district. The Board consists of three or five members, one or two being elected by the industrial unions of employers, an equal number by the industrial unions of workers, and the third or fifth, as the case may be, elected by the other members. The Amendment Act of 1908 abolished the Boards of Conciliation and provided for Councils of Conciliation to take their places.

1 By the Amendment Act of 1908 , the number of persons necessary to register an industrial union was increased from two to three in the case of employers, and from seven to fifteen in the case of workers. 
An industrial dispute can be brought before a Board through the Clerk of Awards by a trade union, industrial union, industrial association, or Disputes employer. If a settlement is arrived at by the parties, it is set forth in an industrial agreement; otherwise the Board makes a recommendation for the settlement of the dispute, which becomes enforceable as an industrial agreement unless the dispute is referred to the Arbitration Court within one month.

Before the year I90I, a case referred to a Board had to be heard by that body before it could go to the

Ignoring the

Boards of Conciliation Arbitration Court; but in that year an amendment was passed permitting either party, after going through the formality of filing the dispute with the Board, to refer the matter to the Court, without any hearing by the Board or any agreement or recommendation. The old rule was re-established in 1908.

A neglected clause of the Act provides for the creation of a special board of conciliators composed of experts in the particular trade to which a dispute relates, elected in equal numbers by the employers and the unions of workers concerned, and vacating their office on the settlement of the dispute. Oddly enough, such a board has been set up only once, in the case of the strike of tramway employees in Auckland in May, 1908. The new conciliation councils established by the Act of 1908 are very similar to these special boards.

There is one Court of Arbitration for the whole of

The Court of Arbitration

New Zealand. It consists of three members appointed by the Governor: a President, who has the status of a judge of the Supreme Court, and two other mem- 
bers, often called assistants or assessors. One of the assessors is appointed on the recommendation of the industrial unions of employers, the other on the recommendation of the industrial unions of workers. By an amendment passed in I906, the title of "President of the Court "was altered to "Judge of the Court." Since the assessors are inclined to be partisan in their decisions, the power is in the hands of the Judge.

The Court may limit the operation of any award to any city, town or other part of an industrial district; or, on the application of any of the parties, it may extend the provisions Limitations and of an award to another industrial dis- Extensi trict. Thus, a number of awards have been extended so as to apply to the whole of the North Island, and some have been given a still wider extension. Extension of awards is usually granted at the request of employers to prevent unfair competition on the part of their rivals in business.

Every award binds not only workers' unions but also individual workers, whether members of unions or not, working for any employer on whom the award is binding; and if any such worker Awards binding commits any breach of award he is liable on Individuals to a fine not exceeding $£_{\text {Io. }}$ Before the year I900 only workers' unions were liable for breach of award. In that year non-unionists were made liable; and, by the Amendment of 1905 , individual unionists also were made liable. Unions of employers, unions of workers, and individual employers are liable to fines not exceeding $£_{500}$; but individual workers are liable to an amount not exceeding $£$ Io.

Mr. John MacGregor has drawn attention to a curious state of affairs existing from I 898 to 1905 , when a 


\section{STATE SOCIALISM IN NEW ZEALAND}

strike or a lockout, although it might be a dispute, Lockouts and was not a breach of award and could Strikes not Ille- not be punished under the Act. Under gal from 1898 to the Act as drawn up by Mr. Reeves, the 1905

Court could declare a strike or a lockout to be a breach of award, but in 1898 the Act was amended with the result as stated. Referring to these years, Mr. MacGregor says:

"An employer who pays, or a worker who accepts, less than the minimum wage thereby commits a breach of award; but, if all the men employed in a factory at the minimum wage were to refuse some morning to resume work, except at a higher wage, they would not be committing a breach, because the Court cannot order any man to work for the minimum."

Strikes and lockouts were made statutory offences by the Amendment of 1905, which prescribed fines not exceeding $£_{\mathrm{I} O O}$ in the case of a union, association or employer, or $£_{\mathbf{I}}$ in the case of a worker. Under this law a large number of strikers have been punished in the past three years.

Fines may be recovered in a summary way under the provisions of the Justices of the Peace Act, I882, and all property belonging to the judgment Fines debtor may be seized and sold for the satisfaction of the debt. Where the property of a union or association is insufficient to pay the fine, the members are liable to an amount not exceeding $£_{\text {Io }}$ for each person. If individuals, employers or workers, alleging that they have no property, refuse to pay the fine, at the discretion of the Court they may be ordered to pay, after which, if they still refuse, they may be imprisoned for contempt. However, imprisonment has never been inflicted for this offence; and, under the Act of 1908 , it is no longer permitted.

By the Act of 1905 , all fines were made payable into the 
public account. Before this time fines levied upon employers were paid into the treasury of the workers' unions, a practice tending to multiply disputes and encourage other abuses.

As intended by its author, the Act has greatly encouraged the formation of industrial unions and associations. Only unions or associations could be registered under the Act.; hence workers desiring to enjoy the benefits of conciliation and arbitration were obliged

Industrial

Unions

Encouraged to form unions, and these soon were federated into associations. The employers, at first, had few organizations; but presently, in order to combat the efforts of the labour unions, they formed unions and associations of their own.

In the year 1896 , there were 65 unions of workers with 9,370 members; and only one union of employers, with 30 members. (J. Ramsay Macdonald, "Arbitration Courts and Wages Boards in Australasia," The Contemporary Review, March, I908.) In the year 1908, there were 325 unions of workers, with a membership of 49,347; and 122 unions of employers, with a membership of 3,91 8 (Annual Report of the Department of Labour, I909, p. I3). Besides these, there are industrial associations of employers and of workers, frequently employing paid secretaries who are very prominent in industrial disputes. These secretaries, like the "walking delegates" of American Unions, have been accused of fomenting disputes, but it had to see how the work of the associations could be carried on without them. Mr. Macdonald thinks that arbitration has "taken the steel out of the unions," that it has increased their membership while taking away their fighting spirit; but the general opinion among both employers and workers is that unions of both 
classes have been greatly strengthened, and the events of the past few years have shown that the workers have a good deal of fighting spirit left. (Aves, Report on the Wages Boards and Industrial Conciliation and Arbitration Acts. London, I908, p. 203.)

The Act of 1894 was designed to provide for the settlement of serious disputes, such as would be likely to lead to strikes or lock-outs; but in prac"Disputes" tice any difference between employers Multiplied and workers is considered a dispute within the meaning of the Act. (Parliamentary Debates, vol. 77, p. 30; Broadhead, op. cit., p. 49.) As has been clearly shown by Mr. MacGregor, " disputes " have multiplied, and the law, instead of being used to settle only serious cases threatening to " arrest the processes of industry," has created something which is not arbitration at all, but a system of governmental regulation of wages and conditions of labour in general. (Industrial Arbitration in New Zealand, by J. MacGregor, M. A., Dunedin, I90I. Also other articles by Mr. MacGregor.) Doubtless Mr. Reeves neither intended nor expected such an outcome, but in the light of subsequent events it is clear that compulsory arbitration could have no other result. Mr. MacGregor very appositely quotes Machiavelli's saying: "Let no man who begins an innovation in a State expect that he shall stop it at his pleasure or regulate it according to his intention."

The Arbitration Act was designed to improve the condition of the working class as well as to prevent Origin of Dis- strikes; and, therefore, practically all of putes the disputes have originated with the workers, while the employers have occupied the position of defendants. Wages were low 


\section{THE ARBITRATION ACT}

in I894, but toward the end of the following year business conditions began to improve and an era of prosperity began which lasted without a break until the winter of 1908 . Had the system of conciliation and arbitration not existed, the workers would have looked to their employers to grant the concessions which they desired; but since the legal machinery was at hand they proceeded to use it to obtain the same results. When any number of workers desired to obtain higher wages, shorter hours or other concessions, they formed a union of seven or more persons, were registered with the Clerk of Awards of the industrial district in which they were, and proceeded to formulate their demands. These would be sent by letter to the employers concerned; and then, if the demands were not granted, a dispute was created which presently came before the Board of Conciliation.

Mr. Reeves thought that most of the cases would be decided by the Boards and that only the most serious cases would come before the Court. In the Session of 1894 he said in Parliament:

"I do not think that the Arbitration Court

Relation of

Conciliation to Arbitration

will be very often called into requisition; on the contrary, I think that in 99 cases in roo in which labour disputes arise they will be settled by the Conciliation Boards; but unless you have in the background an Arbitration Court the Conciliation Boards will not be respected, and they will be virtually useless."

Strange to say, the Boards were not respected because of the existence of the Court, and because it was so easy to appeal to the higher tribunal.

In the early years of the Act a good many cases were settled by the Boards, but the contending parties soon perceived The Boards of Conciliation Ignored that the Boards were not true boards of conciliation, but arbitration courts of first instance; 
and, wishing to have the decision of the highest tribunal, they carried most of the cases to the Arbitration Court. The workers were faily well satisfied with the Boards, since the decisions were usually in their favour, but the employers were very much dissatisfied, and through their influence the amendment of I90I was passed, permitting either party to a reference to go straight to the Arbitration Court. From the coming into operation of the Act until December 3I, I90I, 5I cases were settled by the Boards and Ioo by the Court. From January I, I902, to December 3I, I905, 20 cases were settled by the Boards, and 163 by the Court. In the year 1906 only two cases were settled by the Boards; and in the year 1907, up to May 31, not one case was thus settled, although several recommendations were made. (Broadhead, op. cit., p. 35; Aves, op. cit., p. 93.) Besides, of the cases settled by the Boards in previous years, it is probable that nearly all could have been settled by friendly conciliation without the intervention of the Boards. Since the Act of 1908 went into operation, a number of minor disputes have been settled by the new Councils of Conciliation and the Court has been relieved of many trivial cases.

Many reasons have been given for the failure of conciliation. Mr. Reeves himself says that the system was tedious and cumbrous. ("State

Failure of Conciliation Experiments," vol. 2, p. I31.) In one case a Board spent twenty-six days considering a dispute which was later settled by the Court in half a day. (Parliamentary Debates, vol. I45, p. 248.) Mr. Broadhead says that the members of the Boards were seldom specially qualified, that they were usually in sympathy with the labour party, and were partisan in their decisions. (Broadhead, op. cit., 
p. 3r.) Mr. Aves gives as the chief cause of failure formality of procedure and partisanship. (Aves, op. cit., p. 92.) But Mr. MacGregor points to the root of the trouble when he says: "It is impossible to combine in the same scheme conciliation and compulsory arbitration." ("Industrial Arbitration," p. 2I.)

In other words, conciliation and compulsion are opposed to each other; and the so-called conciliation boards are really arbitration courts of first instance, effective only in so far as they exercise a degree of compulsion, but for the most part ineffective when there is appeal to a higher court.

That governmental regulation is incompatible with freedom of contract was brought out in a forcible way by the Chief Justice, Sir Robert Stout, in a decision by the Court of Appeals in May, 1900. He said:

Contract and Status

"All contracts regarding labour are controlled and may be modified or abrogated. The Court can make the contract or agreement that is to exist between the workman and the employer. It abrogates the right of workmen and employers to make their own contracts. It in effect abolishes contract and restores status. The only way the Act can be rendered inoperative is by the workmen not associating or not joining any union. No doubt the statute, by abolishing contract and restoring status, may be a reversal to a state of things that existed before our industrial era, as Maine and other jurists have pointed out. The power of the legislature is sufficient to cause a reversion to this prior state, although jurists may say that from status to contract marks the parth of progress. (Book of Awards, vol. I., p. 304; Broadhead, op. cit., p. III.)

In a decision rendered in July, 1906, the Chief Justice said :

"The right of a workman to make a contract is exceedingly limited. The right of free contract is taken away from the worker, and he has been placed in a condition of servitude or status, and the employer must conform to that condition." (Broadhead, op. cit., p. 93.)

The judges of the Arbitration Court have been 
invariably jurists of high standing. There have been six judges in fifteen years,- Justices High Standing Williams, Edwards, Martin, Cooper, of the Judges Chapman, and Sim. The position of Judge of the Arbitration Court is not a particularly enviable one, and the judges have always been glad to be transferred to the regular work of the Supreme Court.

Some idea of the work done by the Conciliation Boards and the Arbitration Court may be got from the fact that the total number of awards, Work done by agreements and recommendations made the Court under the Act from its inception until May 3I, 1907, was 535, affecting 78 trades, and including 339 awards, 137 agreements and 59 recommendations. (Aves, op. cit., p. 93; Broadhead, op. cit., p. 213.) The decisions have to do with butchers, bakers, builders, miners, slaughtermen, tailors, tanners, and nearly all other important occupations except agriculture, the professions and the governmental service.

A recent decision relating to agricultural labourers is most extraordinary. It originated in a dispute between

Awards sometimes Refused the Canterbury Agricultural and Pastoral Labourers' Union and the Canterbury Sheepowners' Industrial Union of Employers and about 7,000 farmers in the Canterbury industrial district. The dispute was referred to the Conciliation Board on November 16 , 1906 , and on the same day was referred by the Union to the Arbitration Court. After hearing a great deal of evidence and thoroughly discussing the case in all its bearings, the Court decided, on August 2 I, I908, that no award should be made, on the ground that it was impracticable to fix 
any definite hours for the daily work of general farm hands, and that the alleged grievances of the farm labourers were not sufficient to justify interference with the whole farming industry of Canterbury. Mr. J. A. McCullough, the workers' representative on the Arbitration Court, and a pronounced partisan, strongly dissented from the finding of the Court. In his formal protest he said:

"It appears to me a most extraordinary and despotic proceeding to say that the largest section of the workers in this Dominion should be denied the right to have the conditions of their livelihood, their wages and hours of labour, fixed by means of the legislation which has been expressly provided for this very purpose." (The Press, Christchurch, August 22, 1908.)

And yet, the Amendment Act of 1908, passed a few months later, expressly permits the Court to refuse to make an award if for any reason it considers it desirable to do so.

The awards and agreements made under the Act cover a great variety of subjects, among which the most important are: minimum wages, hours of labour, permits to incompetent workers, limitation of apprentices, periods of apprenticeship, piecework, distribu-

Subjects

Covered by Awards tion of work, holidays, meal hours, provision of tools, modes of payment, notice of dismissal, scope and duration of awards, interpretation of awards, extension of awards, breaches of awards, and fines. In most of the awards, particularly during the early years of the Act, the workers gained something. Mr. Aves says:

"In the whole series of awards, there has been only one insig nificant case when wages have been reduced, and two when hours have been increased. There have, however, been many instances in which, on renewed application of the Court, no fresh award has been granted, and when, therefore, conditions have been left unaltered." (Aves, op. cit., p. 99.) 


\section{STATE SOCIALISM IN NEW ZEALAND}

In most of the awards a minimum wage is granted; and this is never a bare subsistence minimum, but rather an ideal wage such as an able-bodied The Minimum worker of average ability ought to earn; Wage and it has generally been fixed at a point higher than the average wages prevailing in the trade at the time the award was made.

One important effect of the establishment of so high a minimum wage is that workers of less than average

Injury to the Inefficient Worker ability find it hard to obtain constant employment. This difficulty has been partially met by granting under-rate permits to such workers. But most workers, other than old men, do not like to be branded as incompetent, so that not many under-rate permits are applied for or granted. During the years 1902 to 1907 , I,288 permits were granted; 803 by chairmen of conciliation boards, 6I4 by secretaries of unions, and $7 \mathrm{I}$ by stipendiary magistrates, while in I2I cases the applications were not granted. (Aves, op. cit., p. I5I.)

An interesting case occurred after the Auckland Furniture Trade Award of February, 1903, when 3I

Lockouts and Strikes made Illegal workers out of a total force of between 200 and 300 were discharged or suspended by different employers on the ground that they were not worth the minimum wage granted by the award. The Secretary for Labour, as well as the workers' union, took proceedings against the employers for breach of award, but the complaints were dismissed by Justice Cooper, who held that "the employers had done nothing beyond what a reasonable employer is entitled to do in the ordinary regulation of his business." (Books of Awards, vol. 4, p. I35; Broadhead, op. cit., p. 73.) The workers were 
much dissatisfied with this decision, and an amendment was passed in 1905 for the express purpose of declaring such action on the part of employers to be an offence.

"In order to maintain an appearance of equality, it was, of course, necessary to extend the provision to analogous action on the part of workmen, and thus it came about that strikes as well as loçkouts were made offences." (Manuscript by J. MacGregor, I908.)

It is often stated that the granting of a minimum wage works a hardship upon the worker of more than average ability, since the employers, being compelled to pay the minimum wage to a large number of workers of less than average ability, are unable, if not un-

Effect on the More Efficient Workers willing to pay more to superior workers. The general opinion among employers and theorists is that the average wage tends to become the minimum, the minimum tends to become the standard, and the standard tends to become the maximum. (Broadhead, op. cit., p. 72; Aves, op. cit., p. I94; Clark, the Labour Movement in Australasia, p. 230; "Labour and the Arbitration Act," a speech by the Hon. Dr. Findlay, June I7, I908.)

A recent investigation by the Department of Labour shows that wages are by no means so uniform as one would expect from a theoretical point of view. Out of 2,45 I employees in factories in Auckland City, excluding under-rate workers and young persons, 949 received the minimum rate; and $\mathrm{I}, 504$, or $6 \mathrm{I}$ per cent. of the whole, received more than the minimum. In Wellington, the per cent. receiving more than the minimum was 57; in Christchurch, 47; and in Dunedin, 46. (Annual Report of the Bureau of Labour, I909, pp. I33-I43.)

The most reasonable conclusion that one can draw from these facts in relation to the theory stated above, which certainly has some validity, is that the minimum wages awarded in most of the trades are not high, 


\section{STATE SOCIALISM IN NEW ZEALAND}

that the average worker fully earns the award rate, and that it pays the employer in most cases to give higher

The Minimum not Usually too High

wages to the better men. This conclusion

is substantiated by a consideration of the prosperity of New Zealand and of the slight effect which the awards seem to have had on the prices of manufactured articles. It should also be remembered that the superior worker is more regularly employed than the average, so that his yearly wage must be higher than the amount indicated by the figures of weekly wages only. But where the minimum is placed too high there must be a tendency toward a levelling down of wages, which cannot but be discouraging to the more efficient worker, and injurious to the industrial efficiency of the Dominion. For this reason, the objection of the unions to piece-work is probably ill-founded; and, in so far as the Arbitration Court has decided against the piece-work system, it has injured the efficient worker and increased the cost of production of manufactured articles.

In order to prevent such results, Dr. Findlay has suggested a double, or, rather, a primary and a supple-

Suggestion of

Dr. Findlay mentary standard, the primary standard to be a "living wage," based on the reasonable " needs" of workers of different classes, and the supplementary wage to be based on the extra work done by the more efficient workers. In other words, there should be a minimum wage based upon the day's work, and an additional wage based upon the work of the day as a premium upon efficiency. (Findlay, "Labour and the Arbitration Act," Wellington, I908; John A. Ryan, S. T. L., "A Living Wage," New York, I906.) Quite apart from the theoretical difficulties of Dr. Findlay's suggestion, the proposal to 
establish an "exertion wage" was not well received by the labour leaders of New Zealand, who appear to have an ineradicable objection to anything like a task system, and a profound dislike of " pace-makers, chasers, runners and bell-horses." (The Evening Post, Wellington, July 28, I908.)

In the decisions of the Arbitration Court, questions as to wages and hours of labour occupy first place, but close after these comes the claim of unionists for preference of employment. The Preference to Act of I 894 was specially designed "to Unionists encourage the formation of industrial unions and associations," and at first non-unionists were not recognized by the law and were not under the jurisdiction of the Court. It was, therefore, natural that the Court should favour them. The first decision recognizing the unionists' claim to preference was given in December, I896, when the following clause was inserted in the Canterbury Bootmakers' Award:

"Employers shall employ members of the New Zealand Federated Bootmakers' Union in preference to non-unionists, provided that there are members of the union who are equally qualified with non-members to perform the particular work required to be done and are ready and willing to undertake it." (Book of Awards, vol. I; Broadhead, op. cit., p. 105.) Since, however, the employer was the judge of the qualifications of his employees, the unionists did not gain much by this decision. In later awards it was usually specified that preference was granted only when the union was not a close guild but practically open to every person of good character who desired to join. Preference was not usually granted where the unionists were but a fraction of those working at a trade. (Reeves, op. cit., vol. 2, p. I I2.)

Among the arguments in favour of preference, the chief is that the unionists go to much trouble and expense to obtain concessions, Arguments for not only for themselves but for other Preference labourers, and that non-unionists can obtain preference by joining the union. Also, preference is 
sometimes regarded as a compensation to unionists for having given up the right to strike. Preference, too, protects active unionists from being victimized by their employers. Again, unionists generally object to working in the same shop with non-unionists. In brief, the question is practically the same as that of the closed shop in the United States.

Non-unionist labourers object to preference on the ground that it tends to compel them to join the union.

Arguments

against

Preference

Preference, they say, in compulsory unionism. Employers object to preference because it increases the power of the unions and interferes with the employer's freedom in employing and dismissing. In some cases they would discriminate against unionists; whereas, when preference has been granted, they are obliged to examine the employment book kept by the union in order to give the unionists the first chance of employment. Failure to do this is generally regarded as a breach of award.

Preference has been granted in most of the awards. Out of 159 awards in force on March 3I, I906, preference

Unconditional

Preference

Demanded had been granted in II 5 cases, refused in 40 cases, and not asked for in 4 cases. (Broadhead, op. cit., p. II3.) But since preference is usually granted on conditions similar to those mentioned above, the unionists are dissatisfied and demand unconditional preference, which would prevent the employment of non-union men while any unionists were available whether competent or not. The Arbitration Court, except in a few minor cases, has refused to grant unconditional preference, and the unionists, realizing that preference to an open union is no preference at all, now look 
to Parliament for redress and demand statutory unconditional preference to unionists. (Annual Report of the Trades and Labour Council of New Zealand. Dunedin, 1907, p. 38.) This the present Government are opposed to granting, and even Mr. Millar, until lately Minister of Labour, does not favour it. (Parliamentary Debates, vol. I 45 , p. I 88 .

In the administration of the Act, the sympathy of the Department of Labour is generally with the workers, and the employers complain of partiality. From March 3I, I900, to March 3 I, I904, there were 2 I 3 cases of breach accused of of award brought against employers, in

The Department

I7I of which convictions were secured. In the same time there were only 4 cases brought against workers. Since the Inspectors of Factories were made inspectors of awards, in 1903, more complaints have been brought against workers, particularly those taking part in the strikes of the past few years. One would expect more cases of breach of award to be brought against employers, since the awards have usually been made for the benefit of the workers. Also, employers have little to gain by prosecuting workers. When fines are inflicted upon employers for paying less than award rates, they are made large enough to include back wages, except when the workers have knowingly accepted the illegal rates. The Inspectors frequently recover back wages without prosecution. (Annual Report of the Department of Labour, 1909, p. I4.) 


\section{CHAPTER XIV}

\section{COMPULSORY ARBITRATION IN THEORY AND}

PRACTICE

THERE is a pretty well-defined theory in justification of compulsory arbitration in the minds of those who

Theoretical

Basis of Arbitration

favour that method of settling industrial disputes. The competitive system, in this view, has resulted in two great evils: sweating and strikes. Under sweating the workers receive less than enough to secure a decent subsistence for a human being, and the strike is a form of private war in which the strongest win, not those who have justice on their side, and which causes great inconvenience to the public, who are a third party in every strike. All this evil and injustice should be done away with by an appeal to a court, which should establish relations between employers, workers and the public according to principles of justice.

On the surface the theory appears to be highly reasonable, but when put into practice, serious, if not fatal difficulties arise. One of these has Examination of to do with the discovery of specific printhe Theory ciples of justice; the other with the enforcement of awards supposedly just. So great are the difficulties in the way of discovering principles of justice in the determination of wages, that one of the most distinguished of the past presidents of the Arbitration Court has stated that no such principles exist. 
The theory of fair wages that appears to prevail is the doctrine of the living wage, stated both in its negative and its positive form. Stated negatively, the theory holds that extremely

low wages, such as are found under the The Living Wage sweating system, are not fair wages, be-

cause insufficient to afford a decent living according to the colonial standard. (Aves, op. cit., p. roo.) Stated positively, a fair wage is a wage which is sufficient to give the worker a decent living according to the colonial standard, which is higher than the British standard, considerably higher than that of continental Europe, and immeasurably higher than that of the Chinese or Indian coolie. This standard applies, of course, only to the able-bodied worker, because the aged and infirm are not worth so much to the employer. Here is introduced another principle, the principle of payment according to the ability of the employer, and how these two principles can be reconciled it is not easy to show.

Other difficulties arise when the theories are applied to actual cases. For example, a wage which would be quite sufficient for a single man might be inadequate for a married man, and should vary with the size of his family Difficulties and their ability to contribute to their own support. But if a married man is to receive more than a single man of the same ability, he will find it hard to get employment except in the most properous times. Again, a living wage for a skilled worker must be higher than that for a common labourer, since his standard of living is higher. This arises from the fact that skilled labourers are scarce, but this introduces another complicating factor, the supply of labour, which, in densely populated countries, threatens to destroy, not only the theory but the possibility of a living wage. 
These and other complications prevent the creation of a body of legal principles defining and explaining the nature of fair or reasonable wages, No Definite but do not prevent the Court from bearLegal Principles ing in mind the desirability of keeping the customary standards of colonial life from falling, and the equal or greater desirability of raising those standards as much as possible. The doctrine of a living wage, then, is not an established legal principle, but an ideal toward which people may strive; and the Arbitration Court, not being bound by precedent nor hampered by technicalities, and having legislative as well as judicial powers, may do its best to attain the ideal within the limits fixed by economic law. But one hears little about economic law in New Zealand, and much more about justice and fairness in distribution, as though there was no such thing as market value and the effort to attain the desirable had no relation whatever to the possible.

The doctrine of a living wage is nothing more than a starting point for the workers of New Zealand. They

Profit Sharing not established by the Court

demand a living wage and as much more as they can get. Realizing the fact that some employers can afford to pay more than others, the workers desire that some form of profit sharing be established by the Arbitration Court. (Otago Daily Times, May I8, 1907.) But the Court has repeatedly stated that profit sharing could not be taken as the basis of awards on the ground that it would involve the necessity of fixing differential rates of wages, which would lead to confusion, would be unfair to many employers, and unsatisfactory to the workers themselves. (Book of Awards, vol. 7, p. 50; Broadhead, op. cit., p. 6r.) 
In practice, the awards appear to be based on two main principles: first the desire and intention of the Court to secure a living wage to all able-bodied workers; second, the desire Practical of the Court to make a workable award, Principles that is, to grant as much as possible to the workers without giving them more than the industry can stand. In doing this regard must be had to the prosperity of a given industry as a whole, if not to the profits of individual employers. It is usually taken for granted that no reduction will be made in the customary wages in any industry, and, in times of depression, this might be regarded as a third regulative principle. Again, it is the custom of the unions, in formulating their disputes, to demand more than they expect to get, knowing that, in the worst case, they will lose nothing. So frequently has this been done that one might almost lay down a fourth regulative principle, the principle of splitting the difference.

During all the years since the Act was passed, the Government has been in the hands of the Liberal Party, so that both the Government and the judges have been disposed to do what The Court Fair they could for the working class. If they to the Workers have not done more, it is because they

could not, or thought they could not, without grave injury to the industries of the country. Justice Williams, the first President of the Court, said in a letter to the London Times:

" The duty of the Court is to pronounce such an award as will enable the particular trade to be carried on, and not to impose such conditions as would make it better for the employer to close his works, or for the workmen to cease working, than to conform to them. (Broadhead, op. cit., p. 57.) 
The rigidity of system which is characteristic of the railway rates seems to be taking possession of the regula-

\section{Tendency}

tion of wages also. When the awards toward Rigidity in Wages

were few in number it was easy to make a change without any serious disturbance to industry, but now that they are numerous and their scope has been widely extended, it is difficult to make a change in one without making many other changes, for the sake of adjusting conditions of labour to the changing conditions of business. There is, therefore, a temptation to abide by the established conditions. As Dr. Clark says:

"The total effect is to make the condition of status more rigid." ("The Labour Movement in Australiasia," p. 204.)

Another stumbling-block in the way of advance in wages is the inefficient or marginal or no-profit employer, who, hanging on the ragged edge The Inefficient of ruin, opposes the raising of wages on Employer the ground that the slightest concession would plunge him into bankruptcy. His protests have their effect on the Arbitration Court, which tries to do justice to all the parties and fears to make any change for fear of hurting somebody. But the organized workers, caring nothing for the interests of any particular employer, demand improved conditions of labour, even though the inefficient employer be eliminated and all production be carried on by a few capable employers doing business on a large scale and able to pay the highest wages.

This is not to say that even the most efficient em-

Limits to Rise in Wages ployers could afford to pay wages much in excess of those now prevailing. Dr. Findlay has made an elaborate statistical examination of this matter, and arrives at the 
conclusion that if all the net profits, excluding interest, of all the employers in New Zealand, except farmers, were divided among all their employees, the yearly increase in wages would be very small. He says:

"Any attempt to lay violent hands upon these profits would put an end to all business enterprise, and thus destroy the very source from which the profits are drawn." ("Labour and the Arbitration Act," I908, p. I0.)

From such a statement as this it is but a step to the position that wages are determined chiefly by economic laws, and that the Arbitration Court can cause, at most, very slight deviations from the valuations of the market.

It is not easy to show that compulsory arbitration has greatly benefited the workers of the Dominion. Sweating has been abolished, but it is a question whether it would not have disappeared in the years of prosperity without the help of the Arbitration Court. Strikes have

Benefits to Workers not very Great been prevented, but New Zealand never suffered much from strikes, and it is possible that the workers might have gained as much, or more, by dealing directly with their employers as by the mediation of the Court. As to wages, it is generally admitted that they have not increased more than the cost of living. A careful investigation by $\mathrm{Mr}$. von Dadelszen, the Registrar General, shows that, while average wages increased from I 895 to 1907 in the ratio of 84.8 to I04.9, the cost of food increased in the ratio of 84.3 to I03.3. No calculation was attempted for clothing or rent. (Year-Book, I908, p. 539.) A similar investigation by Dr. J. W. McIlraith, of Canterbury College, shows that the combined prices of 45 commodities increased from 1895 to 1907 in the ratio of 93 to 104 , or about 12 per cent.

It is a common opinion in New Zealand that the 


\section{STATE SOCIALISM IN NEW ZEALAND}

increase in the cost of living has been due largely to the high wages and favourable conditions of

Cost of Living Rises

labour fixed by the Arbitration Court, but so widespread a result cannot have been due chiefly to local causes.

There may be, and probably are, cases in which the awards of the Court have compelled manufacturers to raise the prices of their products, but these are probably exceptional. If it is true that in most cases the Court has awarded wages no higher than the industries could stand, and little, if any, higher than the labour market would have effected without arbitration; then it is probable that the increased cost of living has been due chiefly to other causes, to the prosperity of the Dominion, the prosperity of the world in general, and the increased production of gold during the period under discussion. Some think that the rise in prices has been due to combinations of manufacturers and merchants; but while it is true that such combinations exist, their control over prices appears to be very slight. (Parliamentary Debates, vol. I45, p. 212, Speech by Mr. Ell; Clark, "The Labour Movement in Australasia," p. 236; Scholefield, "New Zealand in Evolution," p. 214.)

Manufacturers complain that the awards have been so favourable to the workers as to make it difficult to com-

Cost of Producpete with British and foreign manufaction increased turers, and demand that either the arbiin Some Lines tration system be abolished or that they be given increased protection by increased duties on imported goods. It is claimed that the growth of manufactures has not kept pace with the growth of population and the importation of manufactures from abroad. (Broadhead, op. cit., pp. I36, 2I9.) There is reason to think that the boot trade, fell 
mongering, and flaxmilling have been hampered by the awards, particularly during the depression of 1908-09, when the manufacturers could not adjust wages to the depressed condition of the market. (Aves, op. cit., p. I69; Reeves, "State Experiments," vol. 2, p. I47; Report of the New Zealand Employers' Federation, 1908.) Mr. Broadhead says:

"It is commonly remarked among business people that industrial enterprise in New Zealand has been checked to a considerable extent by the labour laws of the country. It is an undoubted fact that many people having money to invest have been careful to avoid any concern in which labour is the chief item in expenditure. It may be remarked, too, that hardly any new industry has been started for some years." (Broadhead, op. cit., p. 218.)

Even Mr. Millar spoke in the same strain in the House:

"There is a limit beyond which wages cannot go in this country or any other country. The limit between the cost of the imported article and the manufactured article is so small now that the least thing can turn it one way or another." (Parliamentary Debates, vol. I 45 , p. I84.)

There is such agreement among manufacturers as to the effect of compulsory arbitration in increasing the cost of production that their statements cannot be lightly dismissed, especially as many unbiased writers concur in the Manufactures opinion. From I 896 to I90I, there was a period of rapid growth of manufacturing establishments, many of them new to New Zealand, and in those years the number of hands employed and wages paid increased by 56 per cent. and 63 per cent. respectively. From I90I to 1906 the growth of manufactures was considerable, though not so great as during the former period. In this time the population increased by $\mathbf{5}$ per cent., the total imports by 29 per cent., the number of hands employed in manufactures by 22 per cent., the wages paid by 33 per cent., and the value of the output by 
31 per cent. (Year-Book, I909, p. 405.) However, the growth was chiefly in manufactures which have to do with the preparation of raw materials for market, such as meat freezing and preserving, butter and cheese factories, saw-mills and flax-mills. Most of the other manufacturing establishments show a moderate improvement, such as printing establishments, grain mills, tailoring, furniture and cabinet-making, coach building, brick works, agricultural implement works, and sugar-boiling. Others, including woolen mills, show a very slight improvement, while several important industries, including tanning and fell-mongering, iron and brass foundries, clothing and boot and shoe factories and breweries show a falling off.

These statements refer only to the value of the output, as shown in the Reports of the Census. Statistics relating to the profits of manufacturing, as

Profits of given in the Reports of the Census for Manufacturing I90I and I906, in so far as they are to be relied on, show that profits in general are not at all high. In I90I, the total value of manufactures was $£_{17}, 853, I_{1} 3$, while the combined value of

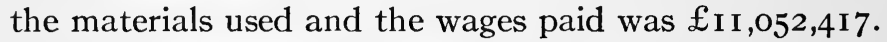
In 1906 , the value of the manufactures was £23,444,235; the value of materials, $£_{13}, 163,692$; the amount paid in wages, $£_{4,457,619}$; and the combined value of materials used and wages paid, $£_{17}, 6 \mathbf{I}_{5}, 3 \mathrm{II}$. (Year-Book, 1909, p. 4I9.) According to these figures, the gross profit in 1906 was less than in 190I, although a much larger business was done in the latter year than in the former. Also, if one were to deduct interest and other items of cost, the net profits of manufacturing enterprise would appear to be quite low. This conclusion is confirmed by the income-tax statistics, which show that, in the year $1907-08$, the gross profits of traders, manufacturers, 
and business men were $£ 7,775,579$, upon a capital of at least $£ 40,000,000$. This, again, does not seem to be a high rate of gross profit, considering the risks undertaken by business men. The profits, however, of merchants, are probably higher than those of manufacturers, if we except meat-freezing and kindred establishments. (Findlay, Labour and the Arbitration Act, 1909.)

Unquestionably, manufacturers, with the exception of the great industries which work up raw materials for market, are not doing any too well; but it is not likely that compulsory arbitra- High Wages in tion is the chief cause of this. The high New Country wages which manufacturers have to pay are due chiefly to industrial conditions which always prevail in a new, thinly populated country with great natural resources awaiting development. The more prosperous the agricultural population, the higher wages must be, and the more difficult it is for manufacturers to find workers. This is particularly true of women workers, for whom there is an active demand in the matrimonial market.

New Zealand manufacturers produce on a relatively small scale, find it hard to compete with imported goods produced under totally different conditions, and are inclined to throw the blame upon the Arbitration Court. Certainly, the Court has done nothing to

Effect of Regulation on Cost of Production lower the cost of production, except in the way of preventing strikes, and has probably increased it somewhat, not so much by fixing minimum wages as by granting, in many cases, limitation of apprentices, prohibition of piece-work, and other restrictions. As Dr. Clark says:

"All regulations restricting the freedom of employers in conducting their business probably add to the cost of production." ("The Labour Movement in Australasia," p. 233.) 
Many employers believe that the cost of production has been increased by a decline in the efficiency of labour due to the fixing of high minimum wages,

Efficiency of Labour which discourages capable men from doing their best work. Mr. G. T. Booth says:

"I am quite sure that the arbitration system has resulted in a loss of industrial efficiency far greater than ever resulted from strikes."

Mr. Booth asserts that the annual output per man in a certain industry (engineering) has fallen from £254 in I90I, to $£ 224$ in I906; but, as Mr. Ell pointed out, this may have been due to other causes. (Parliamentary Debates, vol. I45, p. 210 ; Annual Report of the Canterbury Employers' Association, 1908.) There is much difference of opinion about this matter. In reply to one of the questions sent out by Mr. Aves, 6 employers and I 3 employees said that efficiency had been increased; while 29 employers and I employee said that it had been decreased. (Aves, op. cit., pp. I09, I80). It seems probable that the "go easy" way of working has gained ground in New Zealand in recent years, but the same phenomenon is observed in other countries, and the tendency of trade unionism everywhere seems to be toward a levelling down which cannot but discourage a high degree of industrial efficiency.

The employers, at best, give but a grudging approval to the Arbitration Act. The farmers, as a class, are decidedly opposed to it. (Evening Post,

Opinions of Employers Wellington, June 30, 1908.) Mr. Massey, the leader of the Oppositon, said in the House that he was opposed to compulsory arbitration. (Parliamentary Debates, vol. I45, p. 195.) Mr. William Scott, Secretary of the Otago Employers' Association, says: 
“"Thirfeen years' experience as an employers' advocate before the Court compels me to admit that any method of regulating wages by Act of Parliament must in the end result in failure." (Scott, Address before the New Zealand Employers' Federation, August 28, 1907.)

Mr. Broadhead very fairly sums up the attitude of the employers, thus:

"Some, for business or other reasons, decline to express an opinion on the Act, but say that the Act has been diverted from its original purposes; others, and these, I think, form a large proportion of the employers in the Colony, have little or nothing to say in favour of the Act, and express the opinion that it would have been better for the industries of the Colony if it had never existed." (Broadhead, State Regulation, p. 208.)

It should be remembered, however, that these opinions were expressed when the employers were alarmed and disgusted with the Act because of several important strikes. Since that time they have come to realize that they might have lost more by strikes than they have ever lost by arbitration; and, since the workers have been dissatisfied, the employers are more disposed to stand by the Act, or to maintain a neutral attitude, waiting to see what the workingmen will do. 


\section{CHAPTER XV}

\section{STRIKES}

ThE dissatisfaction of the employers was not the chief of the causes which brought about the Amendment Act of 1908. The original Act and most The Workers of the amendments were passed for the Disappointed benefit of the working class, and had they been satisfied there would have been no material change. The workers expected great benefits from the Act, and for some years they were well satisfied with the results. Travellers from abroad, like Mr. Henry D. Lloyd, found almost everybody loud in praise of the Act, and only a few critics, like Mr. John MacGregor, prophesying against it. When M. Félicien Challaye visited New Zealand in the year I900, he attended a meeting of the Wellington Trades and Labour Council, and got the members to express individually their opinion of the Act. One after another they recited the advantages of compulsory arbitration: higher wages, shorter hours, steady employment, and other benefits. "It has put thousands of pounds in our pockets," said one member. "It is a part of our religion," said another.

But as the early awards expired and fresh disputes arose, the Court frequently declined to make substantial concessions to the workers, who soon began to express their dissatisfaction. According to Mr. Broadhead, the first protest against an award was made at Christchurch, in I90I, when the Christchurch Operative Bootmakers' Society unanimously passed a resolution declaring that the recent award in their"trade was " against the weight 


\section{STRIKES}

of evidence." In August of the same year the Canterbury Trades and Labour Council condemned the action of the Court in refusing to make a complete award in the wool-scouring and fellmongering trades. (Broadhead, op. cit., p. 164; Book of Awards, vol. 3, p. 463.)

From this time complaints against the Court became more frequent and bitter, not because wages were reduced, but because they were not increased, and because other demands were not granted. Great dissatisfaction was aroused because of the Dunedin

Complaints against the Court Seamen's Award of February, I906, when the Court refused to grant the demands of the seamen, on the ground that no substantial difference in circumstances had arisen since the last award. The workers' representative dissented from this decision, which aroused great indignation among all classes of workers. The secretary of the Seamen's Union is reported as saying:

"The seamen have given so-called arbitration a very fair trial, extending over about ten years. The most cherished principles that they are striving for have been denied us by the Court, and improvements in the seamen's condition are evidently not obtainable under the present system of arbitration."

Numerous resolutions were passed by labour organizations condemning the action of the Court, and the Australasian Federated Seamen's Union of Wellington passed a resolution recommending that a ballot be taken of all the members in New Zealand on the question whether the registration of the Union under the Act should not be cancelled. The seamen also considered the advisability of striking, thus reviving echoes of the maritime strike of $\mathrm{I} 890$.

At the Meeting of the Trades and Labour Council of New Zealand, at Christchurch, on April 19, 1906, Mr. D. McLaren moved: 
"That this Conference has no confidence in the Arbitration Court as at present constituted,"

The Judge Criticised

but the motion was lost by a vote of I I to 5. (Report of the Annual Conference of the Trades and Labour Councils of New Zealand, I906.) The motion was a veiled attack on Mr. Justice Chapman, the President of the Court. The term of Mr. Justice Chapman expired at the end of the year, when, at his own request, he was transferred to the regular work of the Supreme Court. He was succeeded by Mr. W. A. Sim, of Dunedin, but with no better results from the workers' point of view. Some have gone so far as to suggest that the Judge of the Arbitration Court should be elected by the people, in the hope that the unions might control the election, but this would be at variance with all British traditions and could not be brought about.

The dissatisfaction finally came to a head $\mathbf{n}$ a series of strikes beginning with that of the tramiway employees in Auckland, on November 14, 1906. Before this time there had been a few The First Strike unimportant strikes (Reeves, "State Experiments," vol. 2, p. 139), and the Auckland strike was not important except as indicating the changing attitude of the workers toward the Act. The conductors and motormen, 222 in number, left their cars about five o'clock on the afternoon of November I4, and remained out until about eight o'clock, when the Company acceeded to their demands. The men's grievance had to do with the summary dismissal of a conductor for alleged misconduct, and the dismissal of ten other employees for refusing to teach "learners." Six months later the Company was brought before the Court and fined $£_{5}$ and costs for having dismissed the 
men without the fourteen days notice required by the award. Of all the men who went on strike, only two were brought before the Court, and these were fined $£_{\mathbf{I}}$ each, without costs. The Court was lenient because it did not consider that the strike had been preconcerted. The next strike began on February 12, 1907, when the slaughtermen employed by two meat-freezing establishments near Wellington struck for higher wages, demanding $25 \mathrm{~s}$. per roo sheep or lambs slaughtered, instead of the old rate of $20 s$. The trouble was settled by a

Strike of Slaughtermen compromise at 23s. The Gear Company resumed work on February I8, and the Wellington Meat Company on the following day. Encouraged by this success, the slaughtermen in various parts demanded higher wages and went on strike when these were refused. In every case a compromise was effected at $23 \mathrm{~s}$. It was not until March 16 that the strikes came to an end. Presently, the men were cited to appear before the Arbitration Court and fines were imposed. The original strikers escaped on a technicality; but all the rest, 266 in number, were condemned to pay $£_{5}$ apiece, the fines amounting to $£_{\mathrm{I}, 330}$ in all. Up to March $3 \mathrm{I}, \mathrm{I} 909, £_{776}$ was recovered, leaving $£_{553}$ unpaid, since the delinquents could not be found, some having gone back to Australia and others being scattered in different parts of the Colony. Since that time orders of attachment of wages were served on those who had ignored the final notice, and by this means about $£$ Ioo more were secured. (Annual Report of the Department of Labour, I909, p. 25.)

Early in the year 1908, a strike occurred among the coal miners of the West Coast which continued for eleven weeks. Seven miners had been dismissed by the manager of the Blackball Company; whereupon all 
the colliers, I20 in number, went on strike on February 27. The men asserted that the miners dismissed

Strike of Coal

Miners at

Blackball

were being victimized because they were active unionists and socialists. The Company was willing to compromise and offered to reinstate the men, but the miners refused to return to work unless some arrangement were made to prevent a similar occurrence in the future, and suggested that when men were to be dismissed they should be selected by ballot. They also demanded thirty minutes lunch time and a strict enforcement of the "bank to bank" principle, according to which the miners were to be underground only eight hours from bank to bank, that is, from surface to surface.

The Department of Labour attempted to effect a settlement of the trouble, but without success, whereupon the Union was cited before the

The Union Recalcitrant
Arbitration Court and a fine of $£_{75}$ was imposed. The strike continued, and the Union went so far as to refuse to pay the fine, alleging that it had no funds. In this position the Union was generally condemned by public opinion, but supported by a number of unions by resolutions of sympathy and gifts of money. Finally, the Arbitration Court decided to proceed against the men individually for their share of the fine. The whole of the fine, together with the costs of collection, amounting to over $£_{I 47}$, was recovered by means of attachment orders under the Wages Attachment Act, I895. According to a recent decision of the Court of Appeals, the men could have been imprisoned, if they had refused to pay, for a maximum term of one year; but it was not necessary to do this and public opinion was not in favour of imprisonment for this offence. 
The strike was ended about the middle of May, when the Company conceded practically everything that the men had demanded. (The Evening Post, Wellington, February to May, 1908; Annual Report of the Department of Labour, I909, p. 26.)

On May 21, 1908, a second strike of motormen and conductors occurred at Auckland and lasted until Monday, May 25. The cause of the trouble was similar to that of the strike of No- A Special Board vember, 1906. Mr. Edward Tregear, of Conciliation the Secretary for Labour, and Mr. A. M.

Myers, the Mayor of Auckland, succeeded in inducing the parties to refer all the questions to a special board of conciliation under Sections $5 \mathrm{I}$ and 52 of the Compilation Act, 1905. This is the only case in which these sections have been applied to the settlement of a dispute. The finding was delivered on July 25, and was largely favourable to the employees. Action was taken by the Department against the Union for bringing about a strike, and a fine of $£ 60$ was imposed, which was paid within twentyfive days. (Report of the Department of Labour, I909, p. 26.) Later in the year, when the Amendment Act was passed, it provided for Councils of Conciliation similar to the special board used to settle this dispute.

A strike of bakers began in Wellington on June 29, I908, shortly after the Court had made an award granting an increase of wages, but not so much as they desired. Although the strike Futile Strike lasted seventy-six days, it was a com- of Bakers plete fiasco, causing no shortage of bread, and the bakers were glad to return to work on the terms of the award. The penalty in this case was £roo, which was paid within one week, as directed. Action was taken against four others for aiding and abetting the strike. 
The Court ruled that the provisions of the Act did not cover such cases, and held " that the strike was complete on the day that the strike took place, and that it was impossible for the respondents to be guilty of the said offences by anything which they did after the date the strike took place." (Report of the Department of Labour, I909, p. 26.) This defect in the law was remedied by the Amendment Act of 1908, which provided penalties for aiding and abetting an unlawful strike or lock-out, and made a strike a continuing offence.

On September 16, 1908, the Hon. J. A. Millar, the Minister of Labour, presented to the House a complete list of the strikes which had occurred since November I4, 1906. He said:

List of Strikes 'The total number of strikes is 23 , and the total number of strikers I, I I 7. The men rendered idle were 2,389 ; the duration of strikes was 316 days; and the loss of wages to workmen amounted to $£ 17,667$. The approximate loss to employers was £ 15,688 . This will give honourable members a fair idea of what the strikes cost the country; and this is, after all, upon a very small scale, as will be seen." (Parliamentary Debates, vol. I 45, I87.)

Trouble in the mining industry arose again because of the new Workers' Compensation Act of 1908, which was to go in force on January I, 1909. Pneumoconiosis The Act provided for employers' liability, Deadlock

not only in case of accident, as formerly, but for some diseases characteristic of certain industries, including pneumoconiosis, or miners' consumption. (Evening Post, Wellington, December 30, 1908.) In order to protect themselves and the employers against the additional risk, the insurance companies required that the workmen concerned undergo a medical examination to show that they had not already contracted pneumoconiosis, or any other of the diseases mentioned in the Act. This the miners refused to do; 


\section{STRIKES}

with the result that most of the coal mines in the Inangahua district were closed pending a settlement of the difficulty. The trouble was neither a strike nor a lockout, but a deadlock, due to a very peculiar situation created by the Act. Although a number of gold miners had submitted to examination, the Waihi Miners' and Workers' Union, representing about I,700 men, on January 7 passed the following resolution:

"That this Union pledges itself not to submit to a medical test. That we endorse the action of those who refused to submit to a test, and are prepared to come out in a body in their support should they not be reinstated by next Monday." (Evening Post, Wellington, January $8,1909$.

The situation was very grave. The Government Insurance Department had very properly refused to assume the extra risk without medical examination, and the Government had. stood by them; but on hearing of the action of the Waihi Union, the Govern-

The

Government Yields ment made a complete change of front, authorized the Insurance Department to issue policies without examination, and agreed to indemnify the Department against loss, pending further legislation. (The Evening Post, January 9, 1909.)

This extraordinary concession was received with astonishment by the public, especially by employers and insurance men, but it prevented a serious strike, and the trouble about pneumoconiosis was ultimately settled by the employers' agreeing to take their own risks against the disease or accept the Insurance Department's offer to insure their workers at an increased rate without medical examination. (Annual Report of the Canterbury Employers' Association, 1909, p. I I.) The whole affair illustrates the difficulty of applying business principles to an enterprise carried on by a democratic government. 
The pneumoconiosis deadlock resulted in a strike of the coal miners at Huntly, who wished to have four socalled "blacklegs" degraded for having submitted to a medical examination; but the miners were clearly in the wrong, accepted a compromise proposed by the Company, and went back to work on January 27.

A trifling strike occurred on January 15, 1910, when seventeen fellmongers employed by the Hawke's Bay Freezing Company at Paki Paki discontinued work for one hour because the Company would not allow them ten minutes, morning and afternoon, for a "smoke-oh," which was not provided for in the award. The men's demand was granted, but the Department took action against the men individually before Mr. S. E. McCarthy, Stipendiary Magistrate, who inflicted penalties of $£_{\mathbf{I}}$ each against the respondents. (Annual Report of the Department of Labour, 1909, p. 26.) From this time until November, 1909, there were practically no strikes.

Possibly, this was due to the industrial depression, possibly to the desire of the workers to give the Amendment Act of 1908 a fair trial, although Strike of they did not expect much benefit from it. State Employees In November, trouble arose in the State colliery at Point Elizabeth, near Greymouth. The men wanted the Department to do the trucking, and the Department desired to make a reduction in the hewing rate to compensate it for the extra expense of trucking. The Manager and the Union could not come to terms, the Union's executive called a strike on November 23 , and all the miners, over 400 in number, quit work. It was an odd coincidence that the strike occurred soon after the beginning of a great strike of coal miners at Newcastle in New South Wales, when some people were demanding the nationalization of the col- 
lieries as the best way of preventing strikes. On this point The Press, of Christchurch, an Opposition paper, said:

"Governments, especially as we know them in New Zealand, are, indeed, much more squeezable by labour agitators than are private employers, and in this fact lies much of the danger to the taxpayer of State incursions into the domain of private enterprise."

Another interesting fact is that the miners were encouraged in their demands by the statements of the Department that the State collieries were earning large profits, although some financial critics deny that any such profits were earned. (The Star, Christchurch, November 24, I909.) One of the miners is reported as saying:

"We are not going to sweat ourselves to pay fat salaries to Sir Joseph Ward and the big bugs. The profits of the State mine should go to the men who dig the coal." (The Evening Post, November 27, 1909.)

After much discussion, the Government was convinced that the miners had substantial grievances; they receded from the position previously taken; and the miners' representatives received the assurance that the Minister Compromise Effected of Mines, the Hon. Roderick McKenzie, would visit Point Elizabeth after the session of Parliament and would give the men conditions not less favourable than those obtaining in other mines. The miners resumed work on Monday, December I3, with the feeling that they had won a great victory. According to agreement, Mr. McKenzie paid a visit to the West Coast and effected a compromise on January 5, 1910. The miners were not prosecuted for striking; for they were no longer under the jurisdiction of the Arbitration Court, since they had allowed their registration to be cancelled by the Department of Labour for failing to send in the annual returns required by law. 
On the day after this settlement was effected, the Wellington Slaughtermen's Union sent a notice to the Slaughtermen Gear Company and the Wellington Meat give Notice of Intended Strike Export Company that they would go on strike in 14 days if their employers would not grant them a rate of $25 \mathrm{~s}$. a hundred for all sheep and lambs not otherwise specified, besides other concessions. The agreement entered into after the strike of 1907 had expired on June I0, I909, after which it continued in force while negotiations for a new agreement were pending. The employers, wishing to have the dispute heard by the Conciliation Commissioner, Mr. P. Hally, according to the new law, drew up a statement and appointed assessors; but the Union neglected to appoint assessors, preferring to settle directly with the employers. On January I4 and I 5, a conference was held at which Mr. Hally presided, though not officially as Commissioner. The conference arrived at terms of peace, by which the slaughtermen obtained practically all that they had demanded. The agreement was to go to the Arbitration Court to be constituted an award for three years. (Evening Post, January I5, I910.)

The strikes of 1907 and 1908 caused a widespread opinion among employers and the general public that the Act should be amended, chiefly

The Act Amended for the sake of preventing strikes. The labourers, as a class, were not enthusiastic about the matter, since the proposed amendments were designed to compel them to obey the law rather than to bring them any additional benefits. A bill was brought down by the Minister of Labour in the session of 1907 , but received little attention. In the session of 1908 the Minister again brought forward a bill, which was actively debated. Finally, the Industrial 
Conciliation and Arbitration Amendment Act, 1908, was passed, and went into effect on January I, I909. The following is a brief summary of the leading provisions of the new law: (Summary of the Industrial Conciliation and Arbitration Amendment Act, I908, by Henry Broadhead.)

The Act gives elaborate definitions of the terms "strike " and "lock-out," stress being laid in both cases on the "intention" of the workers or employers in causing a strike or a lock- Chief Provisions out.

The terms "unlawful strike" or of the Amendment Act, 1908 "unlawful lock-out" mean a strike or a lock-out by parties bound by an award or industrial agreement in the industry affected. For example, the strike of the miners in the State colliery in November, 1909, was not an " unlawful strike," for the registration of the union had been cancelled and there was no award or agreement in force.

Every worker who is a party to an unlawful strike is liable to a penalty not exceeding £ı; and every employer who is a party to an unlawful lock-out is liable to a penalty not exceeding $£_{500}$.

The maximum penalty for aiding or abetting an unlawful strike or lock-out is, in the case of a worker, $£_{\mathrm{IO}}$; and in the case of an industrial union, trade union or employer, or any person other than a worker, £200. No penalties are provided for other than "unlawful" strikes or lock-outs.

Special penalties are to be inflicted when strikes or lockouts occur in certain specified industries: the manufacture or supply of coal gas; the production or supply of electricity for light or power; the supply of water to the inhabitants of any borough or other place; the slaughter- 
ing or supply of meat for domestic purposes; the supply of milk for domestic consumption; the sale or delivery of coal; the working of any ferry, tramway, or railway used for the public carriage of goods or passengers. These penalties are to be inflicted if a worker strikes without having given not less than I4 days' notice to his employer, or if an employer fails to give a similar notice to his employees of his intention to lock-out. It was to escape these special penalties that the Slaughtermen's Union gave notice to their employers, on January 6, I9Io, of their intention to strike at the expiration of 14 days, unless their demands were granted. Strange to say, special notice is not required in the case of a strike or a lock-out in the mining of coal, but only in the sale or delivery of it.

The judgment in any action is enforceable in the same manner as a judgment for debt or damages in the magistrate's court. The surplus of a Attachment worker's wages may be attached above of Wages the sum of $£_{2}$ a week in the case of a worker who is married, or who is a widower or widow with children, or above the sum of $£ \mathbf{I}$ a week in the case of any other worker. Imprisonment for refusal to pay fines is abolished.

The Boards of Conciliation are abolished, and Councils of Conciliation take their place. The only permanent members of these Councils are Councils of the Commissioners of Conciliation, at Conciliation present three in number, who are appointed by the Governor. In case of a dispute, one of the Commissioners goes to the scene and tries to effect a settlement in an informal manner. If unsuccessful in this, he sets up a Council of Conciliation consisting of one, two or three assessors representing the 
employers, and an cqual number representing the workers. Except under special circumstances, every assessor " must be or have been actually and bona fide engaged or employed either as an employer or as a worker in the industry."

Every dispute must be referred to the Council before proceeding to the Court; and in every case the Council is required to make a recommendation, which has no binding force, but operates merely as a suggestion for the amicable Conciliation settlement of a dispute by mutual agreeEncouraged ment and as a public announcement by the Council as to the merits of the dispute. In this respect, the new law resembles the Lemieux Act of Canada, which is a system of investigation and conciliation. However, an agreement, when filed, has all the force of an award; and, if the Council fails to effect a settlement, the dispute is automatically referred to the Arbitration Court.

The Amendment Act of 1908 is a modification of the former system in the direction of voluntary conciliation. Mr. Millar said in the House:

"The main principle of the Bill is to let us go back to conciliation as far as possible." (Parliamentary Debates, vol. I45, p. I86.)

At another time he said:

"In my opinion there are times when the compulsory element requires to be used. I desire to keep the Arbitration Court quite in the background, like a spectre that may be brought forward and made substantial if required." (Ibid., p. 480.)

Thus, the new law is in accordance with the views of Mr. Reeves, the author of the Act of I 894, who believed that most disputes could be settled by conciliation, and favoured arbitration only as a last resort. However, the Amendment Act provides for compulsory, and not voluntary conciliation; and there is reason to think that com- 
pulsory conciliation is not conciliation at all, but compulsory arbitration under another name; and it is, in the last analysis, State regulation of wages and all other conditions of labour.

But there is a way by which the workers may altogether evade the arbitration law and strike as much as they please without rendering themCancellation of selves liable to penalties. After the Registration

expiration of an award, they have only to cancel their registration or allow it to be cancelled by the Department for neglecting to send in their annual returns. This was done by the Point Elizabeth miners, who, therefore, could not be punished for striking. During the year ending March 31, I909, sixteen workers' unions, and a like number of employers' unions, had their registration cancelled for the same neglect, while two other unions formally cancelled their registration. (Annual Report of the Department of Labour, I909, p. 23.) In the words of Mr. Millar:

"The right to strike has not been denied by the House. If the men do not like to voluntarily surrender their rights, let them register under the Trades Unions Act and go on strike every day in the week; but when we pass an Act giving them advantages they could not otherwise get - giving them permanency of employment and regulating wages, and so preventing sweating - I think it is not too much to ask that they should voluntarily carry out their agreement and not strike." (Parliamentary Debates, vol. I45, p. 482.)

There are some weak features in the new Act, as there must be in any attempt to deal with so difficult a subject, but hitherto it seems to have Success of Act Doubtful ten articles in the Evening Post, Wellington, September I 7 to October 5, 1908.) Mr. F. W. Hobbs, President of the Canterbury Employers' Association, says:

"The new system has not had a long enough trial to warrant any definite opinion being expressed as to whether the expectations 
formed of it will be realized. Undoubtedly, a large majority of the disputes which have come before the Councils have been settled, either wholly or in part, and thus the work of the Arbitration Court has been considerably lessened. The operation of the Act will be closely watched, as it is generally recognized that its failure will bring the end to compulsory arbitration as a means of settling our industrial disputes." (Annual Report of the Canterbury Employers' Association, July 23, 1909.)

Undoubtedly, most of the people of New Zealand earnestly desire that the Act may prove successful, and the employers, as a class, notwithstanding their frequent criticisms and their dislike of regulation, would rather have arbitration than strikes, provided that

Public Opinion Favours Arbitration the Court is reasonable in its decisions, as it has been in the past, and does not put upon them a greater burden than they can bear. The employers will not move for the repeal of the Act, but will throw the responsibility for its success or failure wholly upon the shoulders of the workers.

The workers are in an embarrassing position. The Act was passed for their benefit, as well as to prevent strikes; but when it could no longer be used as a machine for raising wages they Position of the were the first to rebel against it. Doubt- Workers less, a large per cent., if not a majority, of union labourers have been much dissatisfied with the Act, and yet most of them are disposed to give the Amendment a fair trial. The more radical among the workers, many of whom are socialists of the type of Tom Mann, regard the Arbitration Court as an instrument of capitalism in keeping the working class in subjection, would abolish the Act, and inaugurate a period of industrial warfare as a prelude to the social revolution.

But the more conservative among the workers wish to do all they can to preserve industrial peace. The Hon. 
J. T. Paul, one of the most capable of the labour leaders, said in the Council:

\section{Labour Leaders} opposed to Striking

"I have no hesitation whatever in saying that I am totally opposed to the strike, that I see absolutely no good in it, and I oppose it for one reason, that it is against the interests of those whose welfare I have most deeply at heart, and against the interests of the general community. Strikes cannot be supported, because they do not help the worker."

In the same debate Mr. Paul quoted with approval the words of Mr. Pritchard, who was a prominent and almost violent supporter of the Blackball miners in the strike of 1908 , who said:

"There is a tendency among a few trade union leaders to influence the members of their organizations to cancel the unions' registration under the Act and I wish as a unionist to protest emphatically against such action on their part. I want to see the best possible method of obtaining as much as possible of the product of labour for the labourer,-and, to my mind, the best system so far discovered is that of compulsory arbitration." (Parliamentary Debates, vol. I45, p. 570.)

The workers are probably in error in thinking that the wages of all classes of labour can be raised much above the market value by means of Market Value unions and strikes, by the awards of a of Labour court, or by any means other than increasing the efficiency and limiting the supply of labour. It would probably be the best policy for the working class to accept rates of wages based on the market value of labour, to encourage the highest possible efficiency, and to increase the provision already made against accident, sickness and old-age, by means of insurance supported by taxation of the incomes of the rich.

But in particular cases, as has been shown by the success of most of the recent strikes, organized labour can frequently force concessions which the Arbitration Court would not grant, and which, if given to all the 
working class, the industries of the Dominion could not stand. The unionized workers, then, numbering about 50,000 out of about 420,000 breadwinners, have interests somewhat opposed to those of the non-union workers as well as to the interests of

Power of Organized Labour the employers and many other people. If, therefore, the unions adopt the policy of cancelling their registration, and try to force concessions from their employers by means of strikes, they will lose the advantages enjoyed under the Act; and, what will be far more serious, they will lose the sympathy of the general public, by whose assistance they have obtained the most advanced labour legislation in the world.

The future of compulsory arbitration will depend upon the attitude of the workers. They could have the Act repealed at any time, but they are The Success of not likely to do that. If they find that Arbitration dethey gain nothing by compulsory arbi- pends upon the tration, they will simply allow their Workers registration to be cancelled, after which they may strike or not as they see fit, and the Act will become a dead letter. Another, and more consistent course which they might adopt would be to stand by the Act and take a more active part in politics with the hope of being able to control the appointment of the Judge of the Arbitration Court, through whom they might obtain concessions impossible to secure under the present political conditions. This, however, has the appearance of a forlorn hope; for even if an independent labour party could step into power, as in Australia, they could not do much more for labour than has been done by the Liberal Party, without serious damage to the industries of the Dominion and serious injury to themselves. 
Dr. Findlay sums up the subject thus:

"It should be the aim of every country to prevent strikes, not by severe pains and penalties, but by providing, if it be possible, such conditions of labour, and such a fair, prompt The Arbitration and competent tribunal as will secure to the Act still an Expériment workers all they can ever reasonably hope to attain by a resort to the blind force of a strike." ("Labour and the Arbitration Act," p. 16.)

At present, the workers do not expect to gain much by appealing to the Arbitration Court; but perhaps they require, not pains and penalties, to keep them loyal to the Government and the Court, but additional inducements of some sort. Possibly the system of arbitration could be brought into some relation to the system of insurance and pensions, so that workers peacefully disposed might receive rewards not granted to those who prefer to appeal to force regardless of the welfare of their fellow citizens. However that may be, it is to be hoped that the interests of all concerned will be secured by methods of peace, and that there will be a successful outcome to the magnificent experiment of compulsory arbitration. 


\section{CHAPTER XVI}

\section{WAGES AND THE COST OF LIVING}

Wages have always been high in New Zealand, as in Australia, the United States, Canada and all other new and prosperous countries. The rates of wages paid in the Province of Well- Wages High in ington in 1873 were not much less New Zealand than those obtaining at the present time. For example, farm labourers received 35s. (\$8.75) a week, with board; carpenters, masons and bricklayers received from Ios. $(\$ 2.50)$ to I2s. (\$3) a day; general labourers $7 s$. (\$1.75) to 8s. (\$2) a day, and so on. (Official Handbook of New Zealand, I 875, p. 70.) On the other hand, the cost of living, as measured by the price of food, was rather less than it is now, and the standard of living was much lower, so that the workman of that period was quite as prosperous as his successor of the present day. Besides, the opportunities of improving his condition, especially by acquiring land, were exceptionally good; and many immigrants who came to New Zealand in the seventies with little or no capital are now well-to-do people with land and other property worth thousands of pounds.

Labour conditions in New Zealand are very similar to those prevailing in Iowa, Kansas, Nebraska, Colorado and other Western states of the Union. Comparison True, New Zealand is more remote with the Westfrom the markets of the world; but it ern States of the has an advantage in that its products Union are shipped to the European markets by sea, and the 
steamship charges on wool and mutton from Wellington or Auckland to British ports are little, if any, higher than the combined railway and steamship charges from Denver, Omaha, or other interior cities of the United States. Therefore, the products of New Zealand can readily be put upon the European markets, and employers can afford to pay good wages, while the enormous distance which European labourers must travel to reach New Zealand deters them from going there and diverts the tide of emigration to the United States, Canada and even South America. If New Zealand were closer to Europe it would get its full share of immigration, its resources would be rapidly developed, and it would not be long before wages would fall, for New Zealand is a country of limited resources and the point of diminishing returns would soon be reached.

Rates of wages and the cost of living vary somewhat in different parts of the Dominion, but taking both together there is not-much difference. Variation in For example, wages are higher in WellWages ington than in Auckland, but in Wellton the cost of living, especially in rents, is higher than in the Northern city, so that the labourer is about as well off in one place as another. In Westland, again, both wages and the cost of living are higher than in Wellington.

The following tables give the wages of typical classes of labourers and the retail prices of staple articles, Comparison of chiefly food products, in and about WellWages and Prices ington, the capital city of New Zealand, in Wellington and Denver, the capital of Colorado. A and Denver

comparison between New Zealand and Colorado is peculiarly fitting; since both are new States with large undeveloped resources; the area and population 
of both are about the same; both are partly mountainous; the industries of both are chiefly agricultural, pastoral and mining; and wages and the cost of living in both are high. The figures for Wellington are from the YearBook of 1909, the Report of the Department of Labour for I909, and the Journal of the Department of Labour for April, 1910. The figures for Denver are the results of an investigation by Mr.W. F. Templin, a senior student in the University of Denver. It should be noted that the New Zealand figures were compiled toward the end of summer in the Southern hemisphere, while the Denver figures were obtained about the beginning of summer in the Northern hemisphere.

Average rates of Wages in the Provincial District of Wellington during the year 1908 compared with wages in Denver and vicinity on May I, I9Io:

\begin{tabular}{|c|c|c|}
\hline Description of Labour & Wellington & Denver \\
\hline 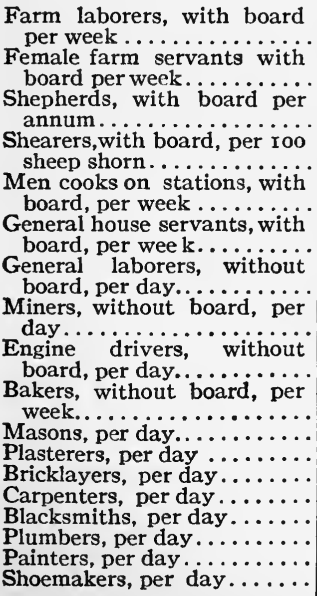 & 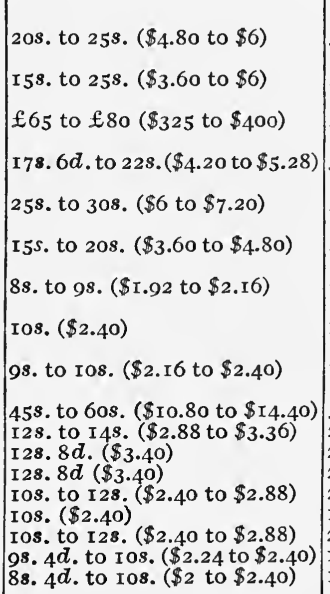 & 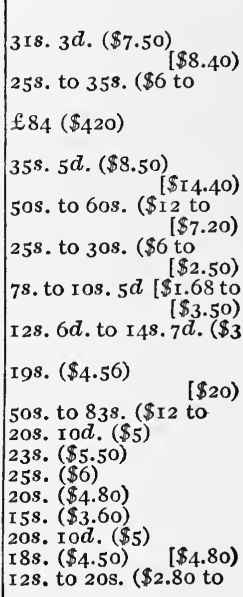 \\
\hline
\end{tabular}




\section{STATE SOCIALISM IN NEW ZEALAND}

\section{Retail prices of commodities in Wellington, on March}

I, I9Io, and in Denver, on May I, I910:

\begin{tabular}{|c|c|c|}
\hline Commodity & Wellington & Denver \\
\hline $\begin{array}{l}\text { Bread, per } 2 \text { pound loaf } \ldots \ldots \ldots \ldots \ldots \\
\text { Butter, I pound, factory } \ldots \ldots \ldots \ldots \ldots \ldots \\
\text { Flour, } 25 \text { pounds } \ldots \ldots \ldots \ldots \ldots \ldots\end{array}$ & $\begin{array}{l}3^{1 / 2 d .}(7 \mathrm{c} .) \\
\text { Is. Id. (26c.) } \\
\text { 3s. } 6 d .(88 \mathrm{c} .)\end{array}$ & $\begin{array}{l}4^{1 / 4 d} \cdot(81 / 2 \mathrm{c} .) \\
\text { Is. } 5 \dot{d} .(34 \mathrm{c} .) \\
2 s .8 d . \text { to } 38 . \text { Id. }\end{array}$ \\
\hline 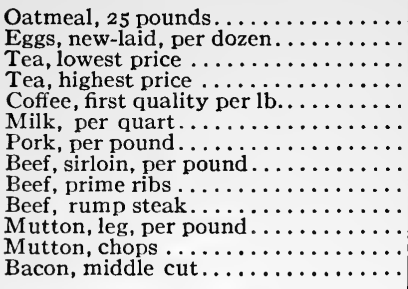 & $\begin{array}{l}\text { 3s. } 3 d .(78 \mathrm{c} .) \\
\text { Is. Iod. (44c.) } \\
\text { Is. (24c.) } \\
\text { 2s. } 2 d .(52 \mathrm{c} .) \\
\text { Is. } 8 d \text {. (40c.) } \\
\quad 4 d .(8 \mathrm{c} .) \\
\quad 6 d .(\text { I } 2 \mathrm{c} .) \\
\quad 6 d .(\text { (12c.) } \\
\quad 4 d .(8 \mathrm{c} .) \\
\quad 7 d . \text { 1 } 4 \mathrm{c} .) \\
4 d .(8 \mathrm{c} .) \\
\text { 5d. (10c.) } \\
\text { I Id. (22c.) }\end{array}$ & 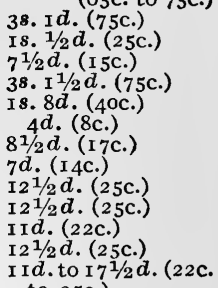 \\
\hline $\begin{array}{l}\text { Fish flounders, per pound } \ldots \ldots \ldots \ldots \ldots \\
\text { Potatoes, per I } 4 \text { pounds } \ldots \ldots \ldots \ldots \ldots \\
\text { Tomatoes, per pound } \ldots \ldots \ldots \ldots \ldots \ldots \\
\text { Apples, cooking, per pound } \ldots \ldots \ldots \ldots \\
\text { Bananas, per dozen } . \ldots \ldots \ldots \ldots \ldots\end{array}$ & $\begin{array}{l}6 d .(\text { ( } 2 \mathrm{c} .) \\
\text { Is. }(24 \mathrm{c} .) \\
\quad 3 d .(6 \mathrm{c} .) \\
2 d .(4 \mathrm{c} .) \\
\quad 6 d .(12 \mathrm{c} .)\end{array}$ & $\begin{array}{l}\text { Iod. (20c.) } \\
5^{1 / 2} d \text {. (I IC.) } \\
5 d \text {. (IOc.) } \\
1^{1 / 2} d \text {. (3c.) } \\
7^{1 / 2} d . \text { to } 2^{1 / 2} d . \\
\text { (I } 5 \text { c. to } 25 \mathrm{c} \text {.) }\end{array}$ \\
\hline 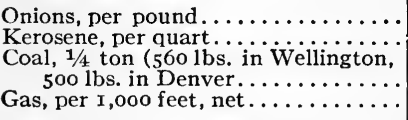 & $\begin{array}{l}\text { Id. (2c.) } \\
5 d . \text { (IOc.) } \\
\text { 7s. } 6 d . \text { to ros. } 8 d . \\
\quad(\$ \mathrm{r} .80 \text { to } \$ 2.56) \\
\text { 5s. } 5 d .(\$ \mathrm{r} .30)\end{array}$ & $\begin{array}{l}2 d .(4 \mathrm{c} .) \\
21 / 2 d .(5 \mathrm{c} .) \\
53.5 d . \text { to } 6 \mathrm{~s} \text {. Iod. } \\
\quad(\$ 1.30 \text { to } \$ 1.65) \\
48.7 d .(\$ 1.10)\end{array}$ \\
\hline
\end{tabular}

Rents of houses let to workmen in Wellington and Denver:

\begin{tabular}{|c|c|c|}
\hline House of & Wellington & Denver \\
\hline 4 rooms, per week & I2s. to 2 Is. $(\$ 2.80$ to $\$ 5)$ & I $2 s$. to I $8 s .(\$ 2.80$ to $\$ 5)$ \\
\hline 5 rooms, per week ... & I $4 s$. to $22 s .(\$ 3.36$ to $\$ 5.30)$ & I5s. to $26 s$. $(\$ 3.60$ to $\$ 6.40)$ \\
\hline 6 rooms, per week ... & I6s. to $25 s$. $(\$ 3.84$ to $\$ 6)$ & I $8 s$. to 3 Is. ( $\$ 4.30$ to $\$ 7.40)$ \\
\hline 7 rooms, per week ... & 208 to 278 . (\$4.80 to $\$ 6.50)$ & $22 s$. to 348 . ( $\$ 5.30$ to $\$ 8,15)$. \\
\hline
\end{tabular}

From these statistics it will be readily seen that the wages of almost every kind of labour are much higher in Denver than in Wellington. The only exception to this rule is the case of general labourers, who are almost as well paid in Wellington as in Denver. In fact, the 
average pay of unskilled labour in New Zealand and in Australia is somewhat higher than the average pay of the same kind of labour in the United States, where a large proportion of Wages Higher unskilled labourers are either negroes or foreigners. Besides, the wages of unskilled labourers in New Zealand are not much less than the wages of some classes of skilled labourers. For example, in Wellington general labourers receive from $8 s$. to $9 s$. a day, while carpenters receive only from Ios. to I2s., and shoemakers from $8 s .4 d$. to Ios. The same level rate of wages prevails in all the Australian States. On the other hand, bricklayers in Denver receive nearly three times as much as common labourers. Dr. Victor Clark explains this peculiar condition as follows:

"The demand for unskilled workers, in pro- The Wages of portion to artisans and factory operatives, is greater in undeveloped colonies, like Australasia Unskilled Labour and New Zealand, than in an older country like relatively High Great Britain. England is in so marked a

degree a manufacturing country, that the British immigration to Australasia probably contained a larger proportion of skilled workers than a new country required. On the other hand, the immigrants to the United States have been very largely land-seekers from the unskilled rural population of Europe. Another potent influence in raising the wages of untrained workmen in Australasia has been the high profit of primary production, due to natural resources large in proportion to population. Other things being equal, the most productive industry usually pays the highest wages." ("The Labour Movement in Australasia," p. 53.)

A comparison in regard to wages between typical cities in New Zealand and the United States is probably the fairest and most accurate that can be Comparison bemade. If one were to compare average tween New Zeawages in New Zealand with an average land and the for the whole of the United States, the United States result would probably be somewhat more favourable to New Zealand, but would not be quite fair to the United 
States, where the average is brought down by the low wages of unskilled colored labour in the southern States and unskilled foreign labour in the more densely populated parts of the northern States. But such statistics as are available show that average wages are higher in the United States than in New Zealand. For example, the New Zealand Census of 1906 gives the average amount of wages paid to male hands in the manufactories in the year 1905 as $£ 88$ :Ios. (\$430), and the average wages paid to female hands as $£_{41}$ :I $7 s$. (\$203), making an average for all the employees, allowing for the number of male and of female hands, of $£_{79}(\$ 383)$. On the other hand, similar statistics in the reports of the United States Census for 1900 show that the average wages paid by the industrial combinations in the year 1900 was $\$ 488$ ( $£$ IOO); while the average for all the manufacturing industries was $\$ 438$; the average for male workers over 16 years of age being $\$ 490$ ( $£$ IоI), the average for women over I6 years of age being $\$ 272\left(£_{56}\right)$, and the average for children under I6 years $\$$ I53 $\left(£_{31}\right.$ ). (New Zealand Official Year-Book, p. 544; Twelfth Census of the United States, vol. 8, p. 982 ; vol. 7 , p. 1xxxi.)

The table of retail prices in Wellington and Denver shows that the prices of meat, especially mutton, are

Low Price of Mutton in New Zealand much lower in Wellington than in Denver. The cause of this is, of course, that the chief industry of New Zealand is the raising of sheep. Indeed, before the beginning of the meat freezing industry the price of mutton was much lower than it is now. In 1873 the regular retail price of mutton in Wellington was $3 d$. (6c.) a pound (Official Handbook of New Zealand, I875, p. 7I), and in the country districts a whole sheep could sometimes be bought for sixpence, (12c.), and sheep 
farmers were known to destroy unmarketable sheep after shearing. It should be noted that the price of meat in New Zealand on March I, I9IO, were lower than usual, while the prices in Denver were higher than usual. It is surprising, considering the relative prices of mutton in the two countries, that New Zealand mutton is not imported into the United States, especially as the import duty is by no means prohibitive.

The prices of other articles of food vary considerably. Flour is cheaper in Denver, but the price of bread is higher, probably because the wages of bakers and the other expenses of baking are higher in Denver. The price of of Food butter is higher in Denver. The price of new-laid eggs varies with the season, falling to I $s$. (24c.) in Wellington, and rising to 40c. ( $1 s .8 d$.) or more in Denver. Potatoes are usually cheaper in Denver, as are most vegetables, also apples, peaches, strawberries and other fruits. However, bananas and oranges are much cheaper in Wellington, being imported from the "islands," although the island oranges are not equal in quality to those of California and Florida. Coal is expensive in New Zealand, but the winter climate in most parts is milder than that of Colorado and less coal is required for heating purposes.

Woollen clothing is cheaper in Wellington than in Denver, but cottons are cheaper in Denver, also silks and fancy articles of many kinds. For six guineas (\$30) a man can get an excellent tailor-made suit in Wellington, which Clothing would cost at least $\$ 40(£ 8)$ in Denver, but the Denver made suit would be superior in fit and finish to the Wellington product. However, for $\$ 30$ one could get in Denver as good a suit ready-made. Cer- 
tainly, a workingman could buy clothes as cheaply in Denver as in Wellington, but they would not be made to order. It is the same with boots and shoes, which are somewhat cheaper in Wellington if made to order, but ready-made shoes are much cheaper in Denver. When New Zealanders travel in the United States they generally buy a large supply of American shoes.

Rents are very high in Wellington as compared with other New Zealand cities, but somewhat lower than in Denver. However, most of the houses in Board and Lodging Wellington are built of wood, while practically all Denver houses are of brick. At the best hotels in Wellington the rates are from Ios. to I2s. ( $\$ 2.50$ to $\$ 3$ ) a day, American plan. Similar accommodations in Denver would cost from $\$ 3$ (I2s.) to $\$ 3.50$ (I $4 s$.) a day. At the best boarding-houses in Wellington the rates are about $£ 2$ :Ios. (\$12.50) a week, or less, while in Denver the standard rate is about $\$ 15$ $\left(£_{3}\right)$ a week. In Denver a workingman can get good board and room for $\$ 5\left(£_{\mathrm{I}}\right)$ a week, and he could not do much better than that in Wellington. Generally speaking, one would get better rooms in Denver and better board in Wellington. Rooms in Denver would almost invariably be heated in winter, while in Wellington fires would involve an extra charge.

Comparisons such as these are very difficult to make, since there are a thousand and one circumstances of which Accurate Comstatistics cannot take account. But the parisons Difficult to Make

indications point to the conclusion that while the cost of living is somewhat less in Wellington than in Denver, the wages of labour are considerably higher in Denver, and the Denver labourer is better off than his brother in Wellington, since there is no reason to think that employment is 
more regular in the one place than in the other. This conclusion is not materially different from that of Dr. Victor Clark, who compares Australasia in general with the United States in general. He says:

"The general welfare of the working classes in Australasia does not differ widely from that in the United States. The hours of work are fewer in most occupations, but the wage per hour is less than in America. The cost of living is about the same in both countries." ("The Labour Movement in Australasia," p. 5I.)

More important than a comparison of wages and cost of living in different countries is a comparison relating to the same country at different times, and the latter can be made with much greater accuracy than the former. A few years ago it was commonly said in New Zealand

Increase in Wages and Cost of Living that wages in the preceding ten or twelve years had increased less than the cost of living, and the inference was that the workers had gained little or nothing from all the social experiments since the time of Ballance. In The Liberator, a single-tax publication, the following statement was quoted from some other publication, which, again, derived it from some unknown source:

"Mr. Coughlan, Government Statistician of New South Wales, affirms that wages have risen $81 / 2$ per cent. in New Zealand during the last fifteen years. In the large centers during that time meat has advanced too per cent., house rent 30 per cent. to 50 per cent., and other items from to per cent. to 50 per cent." (The Liberator, Auckland, November 10, 1904.)

Strange to say, no one was able to find the foregoing statement in any of Mr. Coughlan's writings, but it was widely circulated. About the same time, Mr. Tregear, the Secretary for Labour, in a letter to Mr. Seddon, said:

Opinion of Mr. Tregear

"The results of the Arbitration Act have been of high advantage to the whole Colony, as the great prosperity shown by every indication of the economic barometer denotes. Such effects are, however, rapidly becoming neutralized, and soon only the empty shell 
of an apparent prosperity will be left us if the unbridled coveteousness of a few be not regulated and checked. Some of the necessaries of life cost more than in former years; their price is rapidly advancing, and this out of all proportion to the rise in wages of producers. There has been no fair ratio between the rise in wages and the rise in prices. The chief devourer of the wages of the worker and of the profits of the employer is excessive rent."

In I903, Mr. Tregear presented a report to the House showing that from 1893 to 1903 house-rent in Wellington had risen at least 25 per cent.; meat, 30 per cent.; coal, Io per cent.; firewood in blocks, 50 per cent.; men's clothes (to order), I 6 per cent.; sawn timber, 40 per cent.; ham, bacon and eggs, 25 per cent." (Return H. IIF1903, September 4.) This, however, was not the result of a complete investigation and must not be regarded as final.

Fortunately, a very thorough investigation of the rise of wages and food prices has since been made by Mr. von Dadelszen, the Registrar General, of which the

A Thorough Investigation following is a summary (Official YearBook, I908, p. 539):

\section{ESTIMATED RISE IN WAGES AND PRICES OF NECESSARY FOODS}

After the Census of 1906 was completed a calculation was made in respect of wages paid in the various divisions of labour,- Agricultural, Pastoral, Artisans, Servants and Miscellaneous, - to show the rise since 1895 . The calculation has since been extended to include the year 1907 .

Taking the figures for 1906 in each occupation to represent 100 as a standard, the proportions to this of the rates for previous years and 1907 were ascertained and the figures for the different groups were duly weighted according to the number of persons in each group.

The result shows the index number for each year, thus:

$\begin{array}{rrrr}1895 & 84.8 & 1901 & 89.7 \\ 1896 & 84.3 & 1902 & 93.4 \\ 1897 & 84.6 & 1903 & 96.5 \\ 1898 & 88.7 & 1904 & 98.6 \\ 1899 & 88.0 & 1905 & 98.0 \\ 1900 & 90.4 & 1906 & 100.0 \\ & & 1907 & 104.9\end{array}$


Here the rise in wages is found to have been at the rate of 23 per cent. in 13 years.

The Manufactories' returns, collected at the Census of 1896 and 1906, which state hands employed and wages paid were utilized as a sort of rough check on the above. They showed a rise of 19 per cent., including both sexes and all ages, between the years 1895 and 1905 .

The rise in the price of provisions for the same years was also calculated on the bare necessaries of life divided into three groups,animal food, vegetable food and other necessaries. The price for 1906 was again considered to equal Ioo, and the proportions to this which obtained for the other years calculated. The weighting was according to the proportion of expenditure on the different classes of articles in the consumption of a family.

Index numbers were found to be as under:

$\begin{array}{rrrr}\text { I895 } & 84.3 & \text { I901 } & 89.6 \\ 1896 & 86.1 & 1902 & 105.6 \\ \text { I897 } & 86.1 & 1903 & 100.5 \\ \text { I } 898 & 87.4 & 1904 & 98.5 \\ \text { I } 999 & 83.6 & 1905 & 102.0 \\ \text { I900 } & 86.0 & 1906 & 100.0 \\ & & 1907 & 103.3\end{array}$

The rise is at the rate of $\mathbf{2 2 . 5}$ per cent. for $\mathrm{I} 3$ years.

The result of the whole workings was to show that wages and prices for necessary foods had advanced at nearly equal rates in thirteen years, the wages' calculation having been made on two independent methods, both yielding very similar probable results. No calculation has been attempted so far for clothing or rent.

Lacking other sources of information, the writers made a slight investigation of the rents of workmen's dwellings in and about Dunedin, taking I4 typical houses in different parts of the city, and found that the rents of these

Rents in

Dunedin houses had increased on the average about 20 per cent. from $\mathrm{I} 897$ to 1907 .

Altogether, considering merely daily or weekly wages and the cost of living, it cannot be said that the material condition of labourers in New Zealand has improved much, if any, in the past ten or twelve years. However, there have been practically no strikes in that

Improvement in Condition of Labour time, and employment has probably been more regular than during the years of depression before 1897 , so that 
the worker's yearly wage has increased more than his daily or weekly wage. Also, the various labour laws passed since the time of Ballance,-laws providing for compensation for accidents, regulating the hours of labour, providing for a weekly half-holiday, securing proper accommodation for shearers and agricultural labourers, providing cheap dwellings for workers, allowing old-age pensions, and securing many other advantages to labourers which they do not have in other countries,- - these laws have surely been of some benefit to the working class, especially to the weak and unfortunate.

But it would be impossible for labour conditions in New Zealand to be much better than those prevailing in

Immigration

from

Australia Australia; for, if they were, Australian labourers would migrate to New Zealand and there would soon be an over-supply of labour and wages would fall. Mr. Tregear attributes the slow improvement in labour conditions to the malignant action of landowners and other capitalists; but even if the workers of New Zealand received the whole product of industry, including rent, they would soon have to divide with later immigrants, for labourers are constantly migrating to and fro, and no part of Australasia or New Zealand can long maintain any great advantage over any other part.

The legislators of New Zealand had this principle in mind when they required twenty-five years' residence of all applicants for old-age pensions. If such a restriction were not made, the Dominion would soon be flooded with old people seeking pensions. But the same principle applies to higher wages, lower cost of living, and advantages of every kind, which the Australasian Colonies quickly share' with one another because of the great mobility of labour. This, of course, is not an argument 


\section{WAGES AND THE COST OF LIVING 28I}

against these admirable efforts to improve labour conditions, but merely a partial explanation of the relatively slight improvement which they have effected.

That the depressing effect of immigration upon wages is no mere theoretical abstraction, is clearly seen in the attitude of the workers of New Zealand and Australia toward Chinese and other Asiatics. Like the people of California, the people of Australasia believe

Practical Prohibition of Asiatic Immigration in the "yellow peril," realize that the colonial standards of living and of wages could be destroyed by an invasion of coolies from Asia, and are determined at all hazards to preserve a white Australia and a white New Zealand. For example, the Commonwealth of Australia has a law designed to prevent the immigration of all Asiatics, whether British subjects or not, by means of a "dictation test," which could be used to prevent the immigration of undesirable immigrants of any nationality. According to this extraordinary law, "the immigration into the Commonwealth is prohibited of any person who fails to pass the dictation test, that is to say, who, when an officer dictates to him not less than fifty words in any prescribed language, fails to write them out in that language in the presence of the officer." A Chinese, Japanese or Hindu immigrant would surely be a phenomenal linguist who could pass an examination of this kind, and yet no offence is expressly offered to the people of any nationality, for none are mentioned in the law.

The New Zealand law is more objectionable and somewhat less stringent, and yet it serves the purpose quite effectively. There is a poll- Poll tax and tax of $£_{100}(\$ 500)$ on Chinese immigrants; Combined and "The Immigration Restriction Act, 1908," prohibits the landing of lunatics or idiots, persons 
suffering from a dangerous or loathsome contagious disease, certain convicted criminals, and any person other than of British birth who fails to write out and sign, in any European language, a prescribed form of application. Shipwrecked persons are excepted. (YearBook, 1909, p. 129.) Needless to say, there are few Asiatics in New Zealand. In $188 \mathrm{I}$ there were 5,004 Chinese in the Colony; on December 3I, 1908, there were only 2,998. During that year 538 Chinese came to New Zealand, of whom 320 were new arrivals, who paid in poll-tax the large sum of $£_{32,000}(\$ 150,000)$. Japanese have never come to New Zealand in any considerable numbers, but the Act of 1908 would be sufficient to keep them out. It is no wonder that the Dominion willingly contributes a Dreadnought to the British navy, and would probably welcome an alliance with the United States.

But not only are the labourers of New Zealand alive to the dangers of Asiatic immigration; they realize also

Labour Unions dislike

Immigration that they could not maintain their standard of living in case of a very great immigration from Great Britain and other European countries. Quite frequently letters have been sent to English papers with the object of dissuading labourers from migrating to the Dominion on the ground that the labour'market was already well supplied. On August 26, r906, the president and the secretary of the Canterbury Trades and Labour Council, Mr. Rusbridge and Mr. Barley, sent a letter to twenty-five of the leading papers of Great Britain and Ireland; warning workers against coming to New Zealand, giving statistics as to wages and prices, and stating that the natural increase of the population was sufficient to supply any increasing demands for labour, at least in the building trades, and that there was a good 
deal of unemployment, particularly in the winter months. As quoted in the Manchester Guardian, the writers said:

"Our object in taking this action is chiefly, on the one hand, to disabuse the mind of those who may be under the impression that New Zealand is for workers a realization of Sir Thomas More's Utopia, and, on the other hand, to prevent, if possible, the further crowding of our already over-stocked labour market. Various reasons can be given for the congested state of the labour market at present; but the principal is the steady inrush of immigrants from Britain and the Australian States." (The Evening Post, Wellington, October 19, 1906.)

The reason why New Zealand so quickly feels the effects of immigration doubtless is that she is a small country with relatively limited resources. Migration of LaOnly the great size and the vast unde- bour tends toveloped resources of the United States ward the Equalhave enabled her to absorb so many ization of Wages millions of immigrants without a fall in wages toward the European level. It is hard to see how any country, whether socialistic or individualistic in its industrial organization, can long keep its advantage over other countries without some restriction of immigration. A thoroughgoing experiment in collectivism, therefore, could not be made under favourable conditions in New Zealand or any other country, unless that country were isolated from the rest of the world, or unless the whole world made the same experiment at the same time. 


\section{CHAPTER XVII}

\section{GENERAL SURVEY AND ESTIMATE OF RESULTS}

IN the foregoing chapters an account has been given of the most characteristic activities of the New Zealand Government, but of necessity others of

Other State Activities equal importance have been left out. A discussion of the labour laws alone would fill a volume, and another volume could be made about the inspection of meat, the grading of butter and cheese, and other methods of regulating industry for the protection of consumers and the development of export trade.

The Post Office would repay careful study, with its parcels post, savings bank, telegraphs, telephone exchanges, and the proposed establishment The Post Office of wireless telegraphy. It is interesting to note that the rates for telegrams are about the same as in England and much lower than in the United States, and that the charges for telephone service also are very low. However, the telegraphs and the telephone exchanges are operated at a loss, although the Post and Telegraph Department as a whole earned a profit of $£ 106,342(\$ 500,000)$ in the year 1908-09. This profit, of course, would be much reduced if allowance were made for interest on the cost of the buildings, which must be a very large sum. But the Government does not try to make a profit out of the Post Office, and the Postmaster General said in his Report for 1909: 


\section{SURVEY AND ESTIMATE OF RESULTS 285}

"It should suffice, if the public is being well served, that the Department is paying its way." (Annual Report of the Post and Telegraph Department for the year 1908-09.)

Very important is the work of the Advances to Settlers Office, established by Act of Parliament in 1894, which has lent over $£ 8,000,000(\$ 40,000,000)$ to farmers at five per cent. interest, has lost practically nothing, and earned a Advances to Settlers net profit of $£ 63,835(\$ 310,000)$ in the year 1908-09. The records of mortgages registered shows that in $1895^{-96}$, the year in which the Advances to to Settlers Office began operation, 70 per cent. of the money lent on mortgages bore interest at 6 per cent. and over; while in the year $1907-08,83$ per cent. of the money lent bore interest at 5 per cent. and over, and only 35 per cent. bore interest at 6 per cent. and over. The most common rate of interest on first class mortgages was 6 per cent. in I895; at the present time it is about 5 per cent. (Year-Book, I909, p. 537.) The lending of money by the State has had a marked effect in lowering the rate of interest.

In the year I906, the Government Advances to Workers Act was passed, under which the sum of $£_{571}$,2 Io $(\$ 2,800,000)$ has been lent to workers at 4 I-2 and 5 per cent. interest, which has greatly helped them in acquiring Advances to Workers homes. The net profits of this business

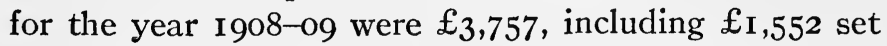
aside as a sinking fund. (Year-Book, I909, p. 589.) In the year I905, the Workers Dwellings Act was passed, providing for the building of houses for workers, to be let at a rental of equal to 5 per cent. on the capital cost, plus insurance. In the year I909 there were in the four cities I05 of these houses, usually of five rooms, with bathroom and scullery, and renting at from $9 s$. (\$2.25) to I7s: $6 d$. 
(\$4.25) a week. (Annual Report of the Department of Labour, 1909, p. xv; Scholefield, New Zealand in Evolution, p. 255.)

Another industry in which the State is engaged is the mining and selling of coal, under the Coal Mines Act, I90I. The price of coal has always been State Coal Mines

high in New Zealand; and at the time the Act was passed it was exceptionally high, owing to the restriction of the output in New South Wales. At the present time the State operates a colliery at Point Elizabeth and one at Seddonville. In the year 1908, the total amount of coal raised in New Zealand was I,860,975 tons; of which the State mines produced 234,250 tons, some of which was used by the State railways and the rest sold at depots in Wellington, Christchurch, Wanganui and Dunedin. The activity of the State in this field has not interfered seriously with private enterprise, although it may have discouraged those who planned to open new mines, especially as the State has reserved some of the richest fields. The production of coal has increased considerably since I9OI, but the demand also has increased and the price has been well maintained. In fact, the price of coal is higher in most places than it was in $\mathbf{1} 899$. The Government claims to have earned a net profit of nearly $£ 20,000(\$ \mathrm{IOO}, 000)$ in the year 1908-09. (Year-Book, I909, pp. 487, 591; Budget, r909, p. ii.)

Of the State coal mines, advances to settlers, lands for settlements and the purchase of native lands, Sir Joseph Ward says:

"The profits earned on these State reproductive investments now reach nearly $£ 200,000$ (\$I, OoO,ooo) after payment of interest and all expenses, and are increasing rapidly from year to year. In addition to this, very beneficial results accrue in the reduction of expenses and cost of living to the general public. It was not intended that these investments should reduce rates to what would be a 


\section{SURVEY AND ESTIMATE OF RESULTS 287}

ruinous competition with private traders and investors. The object was to maintain a fair and reasonable average in order that the public may benefit by obtaining money, coal and land at reasonable rates, which may be said to have now reached the minimum." (Budget, 1909, p. ii.)

In this statement Sir Joseph Ward lays down the fundamental principle of fair competition between State and private enterprise; and if the Govern-

Fair ment will adhere to this, private traders

Competition and investors will have little to fear from State competition. The competition between the State Fire Insurance Office and the private companies has been unfair, because the rates have been so low that proper reserves could not be built up; but competition in life insurance has usually been quite fair, and private companies have done even more than their share of the business. The principles of fair competition are not well understood, and it is impossible to lay down definite rules; but any private business that is to continue to exist must earn enough to pay running expenses and interest on borrowed capital, to provide reserves against depreciation and loss, and to pay off its debts at the proper time. It is probable, too, that there should be net profits, to be used in extending the business or in other investments, that private capital may increase and industrial development continue. If the State can do all these things and still produce more cheaply than private capitalists, there is nothing to be said against State ownership, and the sooner the State takes over every kind of business the better it will be for everybody.

The

But the experience of New Zealand "Government Stroke" shows that when the State conducts business on sound financial principles, private enterprise can more than hold its own. The State has an advantage in that it can 
borrow at low rates of interest, but in regard to efficiency of management the advantage is on the side of private business. As Dr. Clark says:

"Men do not work as well for the State as for private employers Nothing illustrates the last fact more significantly than that the usual term among Australasians for an easy-going pace of work is "the Government stroke." ("The Labour Movement in Australasia," p. 286.)

The carrying on of public enterprises at a loss is frequently defended, because people think more of the

Profit and Loss of Public Business utility or service which the State renders than of the cost of that service; but the opinion is steadily gaining ground that all the business operations of the State should be conducted on business principles, actuarially sound, as insurance men say. It is important that this should be done when the State is competing with private enterprise, as in banking, insurance and the mining and selling of coal; but it is even more important that sound business principles should govern the management of the Post Office, the railways and other State monopolies, where there is no private competition to act as a check upon costly management, obsolete methods and unreasonable concessions to popular clamor.

The Government recently adopted the policy of making the railways pay at least interest on their capital cost, and will probably soon set aside a portion Sinking Funds of the net income for the ultimate extinction of the railway debt. In his great speech at Winton, Sir Joseph Ward said:

"As the outcome of the various undertakings that the Government carry out for the people, it seems to me, after careful consideration, that the question of the provision of sinking funds for the paying off of our loans should be dealt with upon a comprehensive and sound basis." (The Otago Daily Times, May 6, 1910.) 


\section{SURVEY AND ESTIMATE OF RESULTS 289}

There are many who think that the time of borrowing should come to an end and that the time of paying should begin. The Dominion would surely be in a better position if it were no longer a debtor nation and if the whole revenue Public Saving could be used for developmental purposes, instead of being sent abroad to foreign money lenders. Private capital is derived from saving, from a surplus of revenue over expenditure, and there can be no good reason why public capital should not be accumulated in the same way. Indeed, if New Zealand ever became a socialistic State, it would have to establish new industries out of the accumulated profits of the old; for it would be monstrous, if not impossible, to mortgage the country to private capitalists.

At the present time only a few industries are carried on by the State, but the same financial principles apply as if the State owned and managed everything. If the State industries are carried on at a loss, there is a loss to the people as a whole, or else some of the

Business and

Charity people are being taxed for the sake of others, and these not the poor who need charity, but people who can well afford to pay for all that they receive. There should be separate accounts for business and for charity, else there may be no profit in business and nothing to be given in the way of charity.

But although the New Zealand Government has borrowed enormous sums, has entered into competition with private capitalists, has carried on some enterprises at a loss, and has made great concessions to the labouring class, the prophecies of those who looked for dis-

The Government not Bankrupt aster and bankruptcy have not been fulfilled. On the 
contrary, the period of prosperity which began about the year 1896 has lasted, with only a single break, until the present time.

The industrial depression that began in the United States in 1907 spread to New Zealand, caused a good deal of trouble in the winter of 1908 , and still Crises of 1908-09 more in the winter of 1909 , when business was very dull and there was much distress in the large towns. The chief cause of the depression was the decline in the value of the exports from $£_{20,061,641}$, in 1907 , to $£_{16,075,205}$, in 1908. (Year-Book, I909, p. 300.) The worst feature of the situation was the low price of frozen mutton, which fell as low as 2 II-I6 d. (5 3-8c.) in August, I909, on the London wholesale market. But the price of wool was higher in 1909 than in the preceding year; the clip was large; and the Dominion gained on wool far more than it lost on mutton. Also, the price of mutton rose before the end of the year, and the total value of the exports for the year ending March 3I, I9I0, exceeded £2I,000,000 $(\$ 105,000,000)$. Another important factor in the restoration of confidence was the ability of the Government to borrow large sums at from 3 I-2 to 4 per cent. interest. New Zealand suffered less from the depression than either England or the United States; made a more rapid recovery; and, provided that the prices of wool, mutton and dairy produce remain high, is likely to enjoy another series of good years.

The prosperity of New Zealand since the Liberal Party came into power may be measured in various

Prosperity of New Zealand ways. From the year I89I to the year I908, the population increased from 634,058 to 960,642 ; the combined value of imports and exports from $£_{15,903,945}$ to 
$£_{33,365,814}$; the bank deposits from $£_{12,796,098}$ to

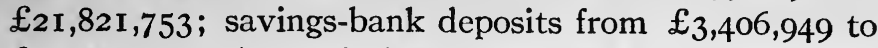
$£_{13,512,266}$; the capital value of land from $£_{122,225}$,-

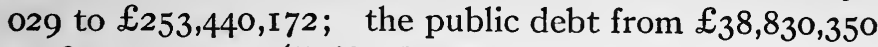
to $£ 70,938,534$. ("Fifty Years of Progress in New Zealand," Year-Book, I909, pp. 637-649.) But probably the best measure of prosperity is afforded by the statistics of total and per capita wealth, which, although not quite satisfactory, are very useful for purposes of comparison.

These statistics have been compiled from the probate returns of estates of deceased persons, which give the average amount left by each person,

from which may be estimated the wealth Average Wealth of the living by assuming that the

average wealth of living adults is the same as that of those who die. The estimate is probably too high, because of the fact that the average wealth of those who die is probably greater than that of the living, many of whom are young persons who have not yet accumulated much property. On the other hand, there is no record of the number and value of estates left to husband or wife of the deceased, as these are not dutiable. Again, there is probably a certain amount of undervaluation of estates for the purpose of escaping taxation.

According to this method, the total private wealth of New Zealand in I89I was estimated at $£_{145,780,504}$, being an average of $£_{230}\left(\$ \mathrm{I}, \mathrm{I}_{5} \mathrm{O}\right)$ per head of the population, excluding Maoris. In the year 1906, the last year for which this calculation was made, the total private wealth was estimated at $£_{304}, 654,000$, and the wealth per head at $£_{335}(\$ 1,675)$. However, this estimate is probably too high, because of the probating of some exceptionally large estates, and the estimate for 1905 seems to be more accurate, which gives the total private wealth 
as $£ 258,7$ I0,000, and the wealth per head as $£ 293$ $(\$ 1,465)$. (Year-Book, I 908, p. 537.)

The method of estimating private wealth by the probate returns has been abandoned as unsatisfactory, and in the Budget for 1909 an estimate is given based on totally different principles. The total wealth of the Dominion is given as $£_{5} \mathrm{II}, 056,384$, being about $£_{500}$ $(\$ 2,500)$ per head of the population, and the figures are compared with those of I89I, which were compiled according to the discarded method. The figures themselves are quite erroneous and the comparison with previous years is altogether misleading. (Budget, I909, p. iii.)

It is not necessary, even for political purposes, to give an exaggerated estimate of the wealth of New Zealand.

Comparison with Other

Countries

Taking the wealth per head at $£_{335}$ $(\$ 1,675)$, as in 1906 , or even at $£ 293$ $(\$ I, 465)$, as in 1905 , New Zealand has a greater wealth per head than any other country in the world. Mulhall's estimate for 1896 gives the wealth per capita of the United Kingdom as \$I,455 (£29I); France \$I,228 (£245); Germany, \$75I (£I50); Canada, \$957 (£I9I); Australia, \$I,247 (£249). The per capita wealth of the United States, in I904, according to the Census Report, was \$I,3 I 8 (£263). The áverage for the United States is brought down by the low average for the Southern states. The wealth per capita of the Northern states is greater than the average. New York, for example, has wealth per capita of $\$ I, 867\left(£_{373}\right)$; Minnesota, \$I,728 (£345); Illinois, \$I,689 (£337); Nebraska, \$1,882 (£376); Colorado, \$2,045 (£409); California, \$2,582 ( $£_{516}$ ). (Special Report of the Census Office on Wealth, Debt, and Taxation, Washington, 1907.) All such comparisons, however, are more or less 
misleading, because of the various methods by which the e. timates are made.

The Liberal Party naturally claims much credit for the prosperity which New Zealand has enjoyed during the past fifteen years, but the basis of this prosperity has been economic rather Economic Basis than political in its character. The of Prosperity natural resources of the Dominion, when

compared with the population, are very great. There are only a million people in a country as large as Great Britain and half of Ireland, with abundance of good land, a fine climate, and an excellent market for all the staple products. Before the days of refrigeration, small farming was not profitable, except in the vicinity of the towns; and even sheep raising on a large scale was a precarious business, depending for its profits on the price of wool alone. But the refrigerator has revolutionized the sheep-raising industry; has built up a large export trade in dairy products; and has done far more for New Zealand than all the legislation of the past twenty years. Mr. Scholefield says:

"Refrigeration was the salvation of New Zealand. At a time when the colony was in the lowest state of depression in its history, when the labour market was glutted with unemployed, and the agricultural classes were disheartened for lack of markets, it gave birth to two industries which rejuvenated the country population and absorbed some of the surplus of the cities; which gave an impetus to the genuine settlement of the land by small men able to work it, and which brought into the country during the worst period of its depression nine millions sterling of absolutely new revenue." ("New Zealand in Evolution," London, 1909, p. I3I.)

And yet it cannot be denied that large landholders frequently stood in the way of closer settlement; and that the efforts of the Government to break up the great estates and to help the small Land Reform farmers in every way have made it possible for many people to live where few lived 
before, and have added not a little to the population and wealth of the Dominion. Even the much criticised borrowing for roads and railways, while it involved the taking of a great risk, has proved to be a good investment; for the country has been rapidly developed and wealth has increased much more rapidly than the public debt.

It is not so easy to show that the labour legislation, with the possible exception of the Arbitration Act, has added to the prosperity of the country.

Labour

Legislation

Labour legislation is a luxury that a rich country can afford; and it may be hoped that it will, in the end, increase industrial efficiency as well as improve the condition of the working class, and thus promote the greatest happiness of the greatest number.

As to State insurance, State ownership of coal mines, and other forms of State trading, while their utility is questionable, they cannot be State Trading shown to have done much harm; and if in the future they are conducted on sound financial principles they will not drive private enterprise from the field, but will do only a part of the business and operate as a check upon the fixing of extortionate prices by private combinations of capitalists. The only danger is that the Government, under pressure of public opinion, may sell products and services at less than cost, ruin private business and establish monopolies in these and other fields of production. But the Government cannot afford to carry on business at a loss, and there is no general demand for the further extension of governmental functions; for many people think that it would be well to wait until the success of the various State experiments is assured before trying any more. Mr. Scholefield says: 
"Of late years the whole tendency has been to leave more and more to private enterprise. It is a swing of the pendulum. Ten years ago the Government would not have dared to suggest allowing private companies to develop the great assets latent in the energy of the rivers of New Zealand. To-day it is the avowed policy of the State to encourage private enterprise in this direction. It is highly improbable now that New Zealand will make any further pronounced advance towards State Socialism until a new temper succeeds to the present mood of conservative Liberalism." ("New Zealand in Evolution," p. 259.)

From the merely scientific point of view, it is a pity that the Dominion is not willing to try experiments even more radical than those of the past few years. Having become the sociological experiment station of the world, she is rather

Social

Experiments expected to go on with the work without too much regard for her own welfare and convenience, to practise a little more vivisection for the benefit of humanity. The conditions are exceedingly favourable: the country is remote, with a small and homogeneous population; the people are intelligent and well educated and have a high standard of public virtue; the soil is fertile, the climate healthful; surely here, if anywhere, the ideals of Utopia could be realized.

But the people of New Zealand do not take this very altruistic point of view. In all their legislation they have in mind their own benefit; and when they think that their experiments have gone far enough, they will stop, regardless of the wishes of people in other parts of the world. Besides, the legislation of New Zealand is not to be regarded as merely experimental in its character, but as arising from a conflict of interests and a series of compromises, resulting in conditions from which the people could not altogether recede even if they wished to do so.

Among these permanent conditions the most important is the State itself, which has increased enormously 
in power since the Liberals came into office in $\mathbf{I} 891$. In fact, one reason why the Liberal Party has remained Power of the State in power so long is that it has had control of an increasing number of departments and an increasing expenditure of money derived from taxation and loans. $\mathrm{Mr}$. Seddon well understood the political effects of making the State the dominant economic power in the Colony; and knew how to strengthen his Government by widening the scope of its activities, by a shrewd expenditure of money, chiefly in the building of roads and railways, and by a judicious distribution of favours of every kind. He taught the people in every part of the Colony to "stand in " with the Government if they wished to be remembered in the distribution of loaves and fishes.

Already there are more than 54,000 persons in the pay of the State; who, with their families, number at least I30,000 persons directly dependent Power of the on the State, and the number of persons Public Servants indirectly dependent on the State must be very great. The public servants are regarded as servants of the people, and are partially disfranch ised in that they are not allowed to take an active part in politics; but their political power, exercised in a quiet way, is very great, and must increase as the functions of the State increase. It is clear that state socialism in a country like New Zealand, with so much centralization of power, could mean nothing else than government by a bureaucracy.

Tendency

toward

Bureaucratic

Government

are controlled
It may be thought that government by a bureaucracy is the same as government by the people, since the public servants belong to Departments which by cabinet ministers who are elected by 
the people; but the departments are not altogether controlled by the ministers in charge, nor even by the chief officials, but by a sort of custom which in the expression of the will of the public servants as a body, who regard first of all their own interests, and, secondly, the interests of the people whom they serve. A department at first exists for the performance of some public service; but after a time it comes to exist for its own sake, and the service which it performs is quite a secondary matter. Indeed, if a department ceased to perform any public service whatever, it would continue to exist as an organization; its members would draw pay and receive promotion; and only a most unusual outburst of public indignation, or the stress of financial embarrassment, could get rid of such a vestigiary and parasitic organ, whose usefulness had long since passed away.

At the present time there is a tendency toward decentralization, which must be regarded as making for greater economy in expenditure and a greater degree of individual liberty. The more closely settled parts of the Dominion are becoming more independTendency toward Decentralization ent of the general Government, more inclined to take charge of their own affairs, and less disposed to favour extravagant expenditure of public funds on roads and railways for the less settled districts. The Government has gone so far as to ask districts needing railways to guarantee at least 3 I-2 per cent. upon the capital cost. It has been proposed that more authority be given to the School Committees, and that the Government no longer pay the whole cost of public instruction, but give pound for pound against money raised by local taxation. In the settlement of industrial disputes the tendency is toward conciliation by local councils of experts rather than 
arbitration by a single court for the whole Dominion. In brief, it is coming to be recognized that the State, the local governing bodies, and the individual have their proper spheres of activity, within which they must be allowed to work, if liberty is to be preserved and the greatest possible social welfare is to be secured.

The word "development" has been the key note of State activity since the time of Vogel. The State has been in the position of a landlord with a

Development Accelerated

vast estate awaiting development,development which would have come sooner or later through private effort, but which has been hastened by the borrowing of large sums for the building of roads and railways, for the purchase and division of large estates, for loans to settlers, for the encouragement of immigration, and for building up the great primary industries of the Colony. This has been an agrarian policy throughout, with the interests of the small farmer predominant. The labour legislation may be regarded as an attempt to divide the profits of development with the labouring class, while the various experiments in State trading have been undertaken for the sake of reducing the cost of living and preventing the growth of oppressive monopolies. The policy of the Government may be open to criticism at many points; but development has been secured, and the Premier has every right to point with pride to statistics showing a rapid increase in population, foreign trade, land values, total and per capita wealth, and material prosperity of every kind. (Budget, 1909; Speech of Sir Joseph Ward at Winton, May 5, 1910.)

But statistics of total and per capita wealth do not give an adequate idea of the prosperity of the mass of the people, since they throw no light on the 


\section{SURVEY AND ESTIMATE OF RESULTS}

question of the distribution of that wealth. Some years ago statistics were collected by the late Dr. C. B. Spahr from the probate court records of certain counties in the State of New York, showing that about one per cent. of the

Distribution of Wealth families owned fully one half of the total wealth. Spahr considered that these counties were typical of the country as a whole; and while he may have been mistaken in this, it is certain that in every part of the country a small minority of the people own a large part of the wealth. This condition is not peculiar to the United States, but obtains to a greater or less extent in all the countries of Europe, and even Australia and New Zealand are not exceptions to the general rule. ("The Present Distribution of wealth in the United States," by C. B. Spahr, New York, I 896.)

It is often said that there are no millionaires and no paupers in New Zealand, but such a statement must not be taken literally. There appears to be as much poverty in the cities of New Millionaires in Zealand as in cities of the same size in New Zealand the United States, and as many people of large wealth. It is probable that no one person in New Zealand owns as much as a million pounds, or five million dollars, but there are a good many who are millionaires in the American sense of that word. The late Jacob Joseph left a fortune of about $£_{300,000}(\$ 1,500,000)$; the late Archdeacon Williams left about $£_{420,000}(\$ 2$, IOo,ooo); and the late Hon. W. W. Johnston left about $£_{500,000}(\$ 2,500,000)$.

Through the courtesy of Mr. George Laurenson, M. H. R., and Mr. C. A. Hickson, Commissioner of Stamps, the

Concentration of Wealth

writers have obtained an interesting return showing 
the number and value of the estates of deceased persons for the years 1903 and 1904. In those years about I0,000 adults died, of whom 2,609 left dutiable estates. The total amount left was about $£ 6,000,000$,

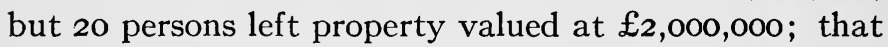
is to say, one fifth of one per cent. of the adults who ried owned one third of the wealth. If we assume that the wealth of living adults, numbering about 500,000 , is distributed in the same manner as the wealth of those who die, which is the assumption made by Spahr, we arrive at the conclusion that about $\mathrm{I}, 000$ persons owned 33 per cent. of the wealth of New Zealand. But there were at that time approximately 180,000 families in New Zealand, allowing, as Spahr does, an average of 5 persons to a family; the conclusion, therefore, is that about one half of one per cent. of the families owned 33 per cent. of the total wealth.

But the figures for the years 1903 and 1904 show an unusual concentration of wealth, as compared with the statistics given in the Year-Books from 1895 to 1903 . Perhaps some unusually large estates were probated in the later years. An average for the years 1895 to 1897 shows that about nine tenths of I per cent. of the families owned 38 per cent. of the wealth; the average for I 898 to I 900 shows that seven tenths of I per cent. of the families owned 30 per cent. of the wealth; and the average for I 90 I to I 903 shows that about I per cent. of the families owned about 35 per cent. of the total wealth.

One would think that the graduated taxes on land and the division of the great estates would have had a

Effect of

Taxation marked effect in equalizing the distribution of wealth, but such has not been the case as yet; as is shown by the fact that from 1893 to 1903 , three tenths of I per 
cent. of the adults who died left 35 per cent. of the value of the property left; while from 1904 to 1907 , about four tenths of one per cent. of the adults who died left about 4I per cent. of the total value. (Year-Book, 1909, p. 542; Year-Books, I 895 to 1904.) In both cases the average value of the largest estates was about $£ 50,000(\$ 250,000)$. It is interesting to note that the average wealth of the 125,000 richest families in the United States, as given by Spahr, was $\$ 264,000\left(£_{53}, 000\right)$.

In Australia, wealth seems to be more unequally distributed than it is in New Zealand. According to statistics given in the Official Year-Book of New South Wales for 1904-05, about I,000 persons own wealth valued at $£_{130}, 000,000$, making an average of

Distribution of Wealth in Australia $£_{130,000}(\$ 650,000)$. These persons represent about four tenths of I per cent. of the families of New South Wales, and their combined fortunes amount to about 35 per cent. of the total private wealth of that State. Probably half of the entire private property is in the hands of not more than 3,000 persons. (The Official Year-Book of New South Wales, 1904-05, p. 543.)

While a large part of the private wealth of New Zealand is owned by a few persons, there is a large class of people in comfortable circumstances, and a large proportion of the families Many Owners own property of one kind or another. of Property The probate statistics show that about 63 per cent. of the families own property valued at $£$ ioo $(\$ 500)$ or over, and it is probable that 75 per cent. of the families are in this class, for a good many small estates escape taxation. Also, of the people classed as propertyless, many are young, industrious, and well-paid wageearners; who, if they have good health and good luck, may 
yet acquire a competency, for the opportunities for advancement in a country so prosperous as New Zealand must be unusually great.

And yet, there is a large number of unsuccessful and discontented people; who have accumulated little or no property, have no source of income The Propertyless other than the labour of their hands and no hope for their declining years but the prospect of a grudging assistance from their children and a small pension from the State. There were relatively more of this class of people in the early nineties than there are to-day, but many of them acquired land and other property, and are now successful and contented. The land legislation of the Liberal Government was socialistic, in a sense; but its effects were anything but socialistic, for it converted land hungry labourers into prosperous farmers, strong supporters of the freehold and the sanctity of private property.

It must be admitted that the benefits of land reform and other Liberal legislation have accrued chiefly to the

Wages in

Relation to

Immigration owners of land and other forms of property, and that the condition of the landless and propertyless wage earners has not been much improved. Indeed, wages could not rise much without causing immigration from Australia, Great Britain and other countries, which would bring wages down again, for the labour market of New Zealand could not absorb a very large number of immigrants in any one year. The Government has done what it could to improve the conditions of labour, and to provide opportunities for acquiring property; that the more capable, industrious and frugal might raise themselves to a condition of independence which they could never attain while they re- 
mained mere wage earners, living from hand to mouth and making no provision for the future.

There is still a good deal of land to be had at reasonable prices, especially in the back blocks, and the Government makes loans to settlers and workers at low rates of interest; but A Discontented these opportunities are open only to those Class

who have saved something and are able and willing to help themselves. But there is a class of labourers to whom this old-fashioned way of getting ahead does not appeal; who think that the Government should provide some royal road to fortune; and applaud the single-taxers who tell them that every inhabitant of the Dominion has a natural right to a share in the land, and the socialists who say that labour should receive, not only wages, but the whole product of capital accumulated by others.

At the annual Conference of the Trades and Labour Councils of New Zealand, held in Wellington in October, 1909, Mr. T. O'Bryne moved: "That Proposed Forthe time has now arrived when the mation of an Trades and Labour Councils should Independent take definite action in endeavouring to Labour Party return Labour members to Parliament." In discussing this motion Mr. O'Byrne said that the Labour Party had been dragged at the heels of the Liberal Party long enough, and that the time was ripe for the formation of an Independent Labour Party. Mr. Hart said that the workers would have got more concessions from the Conservative Party. Mr. Horning said that the workers of New Zealand had got the bone while the capitalists had got the meat. Mr. McLaughlin said that the workers would make a mistake in cutting themselves adrift from the Liberal Party, through whom they had got more 


\section{STATE SOCIALISM IN NEW ZEALAND}

concessions than had been obtained by the Independent Labour Party in Australia. Several other delegates doubted the advisability of breaking with the Liberal Party, but the motion was carried by a vote of 22 to 2 . (Report of the Annual Conference of the Trades and Labour Councils, I909.)

The labour leaders are probably ill-advised in their effort to establish an Independent Labour Party at the present time, notwithstanding the victory of the Australian Labour Party in the elections of r9ro. The urban population of New Zealand is not so great as that of Australia, and the number of people owning property is so large as to offer an insuperable barrier against either single-tax or revolutionary socialism. Besides, an Independent Labour Party could not do much more for labour than has been done by the Liberal Government without driving capital away and ruining the industries of the country. Again, the formation of an Independent Labour Party would probably force the Liberals into an alliance with the Opposition, and prevent further important concessions to labour for years to come.

The Liberal Party is not a socialist party, although it has gone rather far in the direction of state socialism in its efforts to conciliate the working Troubles of the class, through whose support it has Liberal Party remained in power for almost twenty years. The Premier is a financier and business man of great ability, who seems to think that there has been enough radical legislation for the present, and all that he offers to the working class is a voluntary system of national annuities, and other contributory insurance schemes, which will not satisfy the more radical among the labour leaders. There is trouble, too, with the small farmers, hitherto the backbone of the Liberal 
Party, who have been converted to capitalism by the socialistic legislation passed for their benefit. The farmers ask for the freehold and the labourites demand the nationalization of land, while the Government tries to postpone the settlement of both questions as long as possible, knowing that they threaten to disrupt the Liberal Party.

It is probable that some sort of fusion will be effected sooner or later between the Opposition and the more conservative elements in the Liberal Party; and that the more radical Liberals will join an independent Labour The Political Outlook Party in demanding the nationalization of land, and other measures looking toward socialism as the goal, more or less remote. But the party of the property owners will have a large majority at first; and even when New Zealand becomes an industrial country, with great manufacturing industries and a large urban population, it should be possible for the party of property to attach to itself the more efficient among the working class, by giving them high wages, short hours, pleasant conditions of labour, opportunities for promotion, a chance to acquire property, insurance benefits, and greater advantages of every kind than they could gain under any form of socialism. If this can be done, the socialists will be in a hopeless minority, a proletariat of the inefficient, for whose improvement everything will be done that can be done, but for whom the community could not sacrifice itself without peril of decay and ruin in the struggle for racial supremacy now impending.

The most momentous question of the day in New Zealand, as in Australia, is not the land question, nor the labour question, but the question of Asiatic immigration. Even the socialists, with all their internation- 
alism, demand the exclusion of coolie labour, because they realize that unrestricted immigration might bring

The Peril of

Asiatic

Immigration

down the standard of living to the Asiatic level and overwhelm colonial civilization with a Mongolian invasion. The danger may appear slight and remote to people dwelling in security in the interior of the American continent, or on the Atlantic coast; but it looks dark and threatening to the inhabitants of New Zealand, Australia, California, and all the European communities on the Pacific Ocean. What the British Colonies need most is not more socialistic legislation, but an alliance with the United States; and who shall say that the United States does not need an alliance with the British Empire, if not for the open door in China and the mastery of the Pacific, at least for the preservation of Anglo-Saxon civilization? 


\section{INDEX}

A

Accounting, importance of, 70, 106, 107, I16, 215.

Advances to Settlers, I6, II3, 285.

Advances to Workers, 15, 285.

Alison, E. W., I 50, 212.

Allen, James, I05, 2 I9.

Anstey, Hon. John, 193.

Arbitration, industrial, 216-268.

Arbitration Court, the, 222, 223, $227,228,230,25$ I , 252, 254, 263, $265,267,268$.

Awards, 223, 228, 230, 23I, 24I, 242.

Awards, enforcement of, 238, 252$260,262$.

Awards refused, 230, 23I.

Breach of award, 223, 224, 232, 233, 237.

Compilation Act, 1905, 220-225.

Conciliation, 221, 222, 227, 228, $229,255,260,262,263$.

Cost of production, 234, 243, 244, 247.

Disputes, 222, 226.

Dissatisfaction, 250-260.

Efficiency of labour, 233, 234, 235, 248.

Fair wages, 234, 238, 239, 240, 243.

Fines, 223, 224, 252-262.

Incompetent worker, the, 232 .

Minimum wages, 232-234.

Preference to unionists, 235-237.

Registration, 221, $225,227$.

Registration, cancellation of, 22I, 25I, 26 I, 264, 266, 267.

State regulation of wages, 226, 229.

Strikes and lockouts, 224, 232, 243, $249,250-261,264-266$.

Argentina, 12.

Aristotle, I9.

Asiatics, II5, I87, 239, 28I, 282, 305, 306.

Atkinson, A. R., 184 .
Atkinson, Sir Harry, 98, 123, 190, 209.

Australia, 7, 12, 14, 15, 56, 91, I52, 207, 21 2, 269, 273, 277, 280, 281, 301, 304 .

Australian Mutual Provident Society, I57-163.

Aves, Ernest, 226, 228, 229, 230, 23I, $233,239,245,248$.

\section{B}

Ballance, Hon. John, I2, 15, 23, 28, 39 . 99, I 22, I25, 2 I 8, 277, 280.

Barclay, A. R., 2 Ir.

Baume, F. E., I35, 202.

Bell, Dr. Mackintosh, I77.

Booth, G. T., 248.

Broadhead, Henry, 218, 220, 226, 228, $230,233,235,240,244,249,250,26$ r. Brydone, Thomas, Io.

Buckle, Henry Thomas, $\mathrm{I}$.

\section{C}

Canada, 2, 3, 4, 12, 34, 35, 88, 94, 263, $269,270$.

Capital, private, $3,49,50,56,102,135$, I 78, 245, 265, 287, 289, 305 .

Centralization, 7, 207, 296, 297.

Challaye, M. Félicien, 250.

Chapman, Justice H. S., 230, 252.

Charitable aid, I79-I83, I87, I88, I93, I94.

Cheviot Estate, 4I, I29.

Clark, Dr. Victor, 2, 87, 233, 242, 244, $247,273,277,288$.

Class legislation, $4,5,32,35,295,303$, 304.

Climate, 34, 52, 295.

Coal mines, State, I5, 286.

Colorado, 269-277.

Competition, I58, I65, I69, I7 7 -178, $214,287,288$.

Constitution Act, 4, I 17 .

Consolidated Fund, 96, I04, II3, 117. I 18 . 
Cooper, Justice T., 230, 232.

Cost of living, 243, 244, 269-283.

Coghlan, T. A., 277.

Credit, State, 6, 2I, Ior, I02, II3, II4, 289, 290.

Crisets, industrial, $7,9,12,18,59,60$, 98, I I 2, I I6, $216,290$.

Crombie, C. B., 133 .

Crown lands, 3, 20-33.

\section{D}

Dairy produce; Io, II.

Dalston, H. M., 63.

Death duties, I34, 135 .

Death rate, 153 .

Debt, public, 6, 21, 42, 43, 57, 94-II6, 294.

Denver, wages and prices in, 270-277.

Development, 35, 82, 85, 96, I08, 298.

Discontent, 8, 9, 17, 302, 303 .

Dreadnought, gift of, II5, 282.

Duthie, John, 2 I9.

E

Education, 6.

Edwards, Justice W. B., 230.

Ell, H. G., 29, I4I, I5I, $244,248$.

Emigration, 9.

Employers' liability, I5.

Enterprise, State and private, 3, 4, 54, 60-63, I54, 157, 158, I60, 165, 166, $169,167-178,2 I 4,215,286,287,288$, 295.

Expenditure, public, 58, 68, 7 I-80, 83, $84,91,92,107$, I09, III I I 2, II5, I34, I36, I88, I89, 209, 2 I 4.

Exports, II, 99, I20, 290.

F

Factories Act, 15, 216.

Farmers in politics, 12, 16, 26, 27, 28, $32,37,38,44,5$ I, I24, I25, I30, I33, I $5 \mathrm{I}, 248,298,305$.

Fergus, Hon. T., 2 I9.

Fire Insurance, State, I67-I78.

Premi ums, I 7 I, I 74, I78.

Reserves, I 73, I 75 .

Expenses, I 73.

Profit and loss, I73, I74, I75, 28
Findlay, Hon. J. G., I8, 46, 131, I93, I94, 233, 234, 242, 247, 268.

Fisher, Hon. Andrew, 15, I05.

Fisher, H. S., 25.

Fitzroy, Governor Robert, I 22.

Fowlds, Hon. George, 29, I5 I, I74.

Fox, Hon. William, 6.

Fraser, William, I02.

\section{G}

General Assembly, powers of, 4, 5, II 7 . George, Henry, 29, 5I, I22, I 25, I33, I39, I 40, I5I.

Gladstone, Right Hon. W. E., I54.

Government stroke, 8I, 288.

Grey, Sir George, 38, 6I, 88, 122, 218.

\section{$\mathrm{H}$}

Hall, Sir John, 2 I 9.

Hall-Jones, Hon. W., 99, I I0.

Hally, P., 260.

Harkness, J. G., 2 I9.

Hector, Sir James, 58, 59.

Herdman, A. L., I35, 206, 207.

Heyes, P., I 44 .

Hickson, C. A., 299.

Hutcheson, J., I9I.

Hobbs, F. W., 264.

\section{I}

Immigration, 6-9, 38, 58, 18 I, 270, 280$283,302,305,306$.

Imports, I $20,290$.

Inflation, $7,59,98$, I I2, I3I.

Interest, rates of, 285 .

\section{K}

Knights of Labour, I4.

Knowles, John, 56, 57, 68.

\section{$\mathbf{L}$}

Labour, co-operative, 72.

Labour in politics, 8, I3, I4, I5, 27, 5I, I 52, 2 I I , 2 I 7, 236, 237, 250, 257, 259, $265,267,282,298,303,304,305$.

Labour legislation, I5, 294. 


\section{INDEX}

Laissez-faire theory, I, 17, 18, 38.

Land question, the, 12, 16, 20-51, 293.

Absentee ownership, 47, 51, 128, 129.

Closer settlement, I6, 38-49, 293.

Freehold tenure, 23, 33, 305.

Large holders, 5, 9, 12, 13, 35-51, 125, $128,129$.

Leasing of Crown lands, 20-33, 57.

Limitation of areas, 50.

Small holders, II, 12, 13, 16, 36, 37, 125.

Speculation, 44, 59, 10I, 13I, 139.

Taxation, II 7-I 52.

Unimproved values, 122, 125, I26, I29, I38-I52.

Valuation, 16, 22, 23, 27-30, 40, 129-132, 139.

Liberal Party, I 2-I 5, 99, I03, 21 7, 24I,

267, 290, 293, 296, 302, 303, 304.

Life Insurance, State, I 53-166.

Premiums, 158.

Expense ratio, 159-161.

Bonuses, I6I, 162.

Lapses, $162,163$.

Investments, 164 .

New business, I 58, 165 .

Lloyd, Henry D., 250.

Lloyd-George, Hon. David, 32, I9r.

\section{M}

Macdonald, Hon. J. Ramsay, 225.

MacGregor, Dr. Duncan, 180, I8I.

MacGregor, John, 223, 224, 226, 229, 233, 250.

Machiavelli, 226.

Manawatu Railway, 60-62, 91, 1 Io.

Manchester School, I.

Mander, Francis, 29.

Mann, Tom, 265.

Manufactures, growth of, 245, 246.

Maoris, 55, 96, 98, 1 I 9, 291.

Maritime Strike, 14, 216, 2 I 7.

Martin, Justice J. C., 230.

Maskell, W. H., 53.

Massey, W. F., 102, 106, 248.

McCarthy, S. E., 258.

McCullough, J. A., 2I0-2I4, 23 I.

McIlraith, J. W., 243.

McKenzie, Sir John, I5, 24, 26, 39.
McKenzie, Hon. Roderick, 259.

McLaren, D., 25 I.

McNab, Hon. Robert, 45.

Menger, Carl, 50.

Midland Railway, 62, 63.

Millar, Hon. J. A., 75, 76, 92, 197, 201,

$217,237,245,256,263,264$.

Mutton, frozen, 10, I I, I2, 99, 290.

\section{$\mathbf{N}$}

National endowments, 22, 31 .

Neill, Mrs. Grace, I8I.

Newcastle strike, I5.

New Zealand Company, 2, 7, 52.

\section{O}

O'Byrne, T., 303.

Okey, H. G. H., 2 I2.

Opportunist legislation, 17.

O'Regan, P. J., I40, I4I.

\section{$\mathbf{P}$}

Parsons, Professor Frank, 91, 168.

Paternalism, I8.

Paul, Hon. J. T., 266.

Pensions, old-age, I 79-I96.

Perpetual lease, 22, 23, 26, 30.

Perpetuity, lease in, 24, 25, 26, 30.

Pilcher, E. G., 55, 57, 59.

Politics in relation to State enterprise, $58,74,78,83,85,87,91$, 108, 109, I I0, 257, 259.

Population, I I, 216, 245, 290.

Post Office, 284 .

Postal Savings Bank, 5, 284.

Poverty, I 79-1 83, 299, 302.

Preferential tariff, I 20.

Profits of private business, 246, 247. 263.

Profits of State enterprise, $43,58,60$, 68, I03, I16, I36, 259, 287, 289.

Productive investments, 95, 96, 116 .

Protective tariff, I20, I21, 244.

Provinces, the, 2, 3, 4, 5, 7, 21, 53, 54.

Public Service, 197-215, 296, 297.

Appointment, 198, 199, 200.

Classification, 200-204. 
Public Service:

Efficiency, 80, 8I, 203, 204, 205. $214,215,288$.

Retrenchment, II4, I36, 208, 209.

Patronage, 199-203, 206.

Politics, 2I0-2I4.

Promotion, 202-206, 208.

Tenure of office, 205, 207.

Public Trustee, 6.

Public Works Fund, ro4-r Io.

Public works policy of Vogel, 6, 2I, 5559.

\section{$\mathbf{R}$}

\section{Railways, 3, 6, 9, 54-93.}

Accommodation, 64 .

Addington workshops, $8 \mathrm{I}$.

Additions to open lines, 70, 7 I, 76.

Commissioners, 68, 69, 73, 80, 90, 91, 206.

Cost, $71,72,80,86$.

Deficits, $71-76,82,84,85$.

Fares and freight charges, 65,66 , 67.

Finance, 68-93.

Gauge, 56, 64 .

Mileage, 63 .

Political railways, $58,69,84-87,91$.

Private railways, 60-63.

Provincial railways, 54, 55, 56.

Railway servants, pay of, 77,78 .

Rating on unimproved values, I39-I52.

Reeves, Hon. W. Pember, 3, 8, I3, I5, $2 \mathrm{I}, 38,52,57,59, \mathrm{I} 23, \mathrm{I} 24, \mathrm{I} 25, \mathrm{I} 27$, I $7 \mathrm{I}, 190,217,218,219,220,224,226$, $227,228,235,245,252,263$.

Refrigeration, I0, Ir, I 2, 99, 293.

Renewable lease, $30,32,44$.

Revolution, political, 7, I2, I4, 35, 99.

Roads, $3,6,37,52,53,54$.

Rolleston, Hon. William, 5, 22, 24, 26, 28, 38 .

Ronayne, T., $8 \mathrm{r}$.

Ruskin, John, I96.

Russel, Lord John, I22.

Rusbridge, H., 282.

Rutherford, A. W., 201.

Ryan, Professor John A., 234.

$\mathrm{S}$

Scholefield, Guy H., 8, 9, ro, 14, I 7, $244,286,293,294$.
Scott, Professor R. J., 8 r.

Scott, William, 248.

Seddon, Right Hon. R. J., 28, 69, 98. 99, I08, I09, I20, I 72, I82, I85, I90, I9I, 277, 296.

Segar, Professor H. W., I 53, 195.

Single-tax, 27, I25, I39, I40, I4I, I42, I $43, I_{5}$ I, 278, 303.

Sinking fund, I02, I03, II6, 288.

Sim, Judge W. A., 230, 252.

Socialistic tendencies, I9, 49, 5I, 302 , $303,304,305$.

Social utility of State enterprises, 83 , 84, 108, 288, 289.

Spahr, Dr. C. B., 299, 300.

State Accident Insurance, 16.

State activities, origin of, I-I9, 296.

State coal mines, I6, 286.

State Fire Insurance, I6, I67-I78.

State Life Insurance, 5, I53-I66.

State telegraphs, 5 .

State telephones, 5 .

State Tourist Department, I6.

State trading, I6, I36, 214, 294, 298.

Stephens, A. G., 89.

Stephenson, Robert, 56.

Stevens, Hon. E. C. J., 39.

Stewart, Hon. W. Downie, 2 I7, 2 I9.

Stockwell, H. G., 70 .

Stout, Hon. Sir Robert, 22, 98, I461 I94, I98, 229.

Strikes, 21 7, 218, 224, 250-268.

Surplus, the, I05, I06.

Sweating, I4, $216,238,239,243,264$.

\section{$\mathrm{T}$}

Taxation, I I 7-I52.

Death duties, I34, I35.

Evasion of taxes, 45, 46, 132.

Graduated land tax, 45-49, I 28I32.

General property tax, I23.

Local taxation, I38-r52.

Land and Income Tax, 46, I21I37.

Tariff, the, I2I.

Taxation of mortgages, I26, I27. I 28, I 32.

Ordinary land tax, 126.

Per capita taxation, II9, I 20.

Stamp taxes, I34. 


\section{INDEX}

Taylor, T. E., 186.

Templin, W. F., 27 r.

Thomson, J. C., 107.

Tregear, Edward, 255, 277, 278, 280.

Truck act, 15.

\section{U}

Unearned increment, 24, 26, 43, 62, 83 .

United States, 2, 4, 12, 34, 35, 52, 64,

$65,88,94,110,117,119,120,173$, $187,203,204,269,273,274,275,276$, 277, 283, 292, 299, 301, 306.

University, New Zealand, 6.

\section{V}

Village settlements, 5 .

Vaile, Samuel, 88-9I, 142.

Valentine, Dr. T. H. A., 182 .

Vogel, Sir Julius, 5, 6, 8, 9, 55, 56, 58, 83, 97, I I3, I 54, I 55, 208, 298.

Von Dadelszen, E. J., 243, 278.

$\mathbf{W}$

Wages, 77, 243, 244, 247, 269-283, 302. Wakefield, Edward Gibbon, 7, 21, 36, 52.

Ward, Right Hon. Sir Joseph George, $44,75,77,79,87,99,103,109, I_{13}$, I 14, I 35, I 73, I86, 194, 203, 205, 206, 209, 2 I 2, 286, 287, 288, 298.

Warren, Senator F. E., III.

Wealth, distribution of, 19, 292, 299. 300, 301, 302.

Wealth, private, 97, $114,291,292,299$. 301.

Wellington, wages and prices in, 270277.

Williams, Justice J. S., 230, 24 I.

Woodward, J., 156.

Wool, I0, II, I 2, 34, 290, 293.

Workers' Dwellings, I5, 285. 



$\begin{array}{lllll}\text { HD } & 3616 \quad \text { A84 N7 } 1910\end{array}$ SMC

Le Rossignol, James

Edward, 1866-1959.

State socialism in New

Zealand /

AAF-5051 (mcsk) 
$3 \% \& 8 \% \& \% \& \%$

$8+\infty \times \infty$

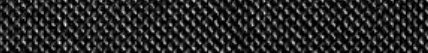

\%



.

\%

$8+8 \times 8$

\%

(6)

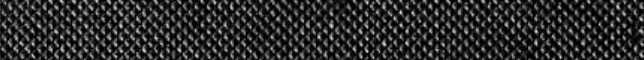

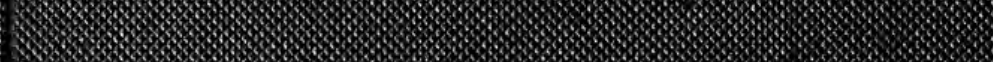

-

-

$3 \%$ \%

(8)

F

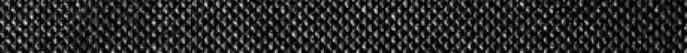

\%

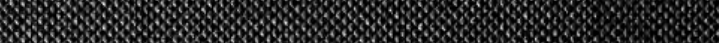

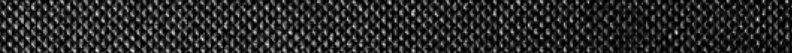

\%

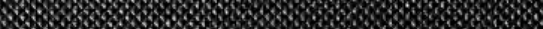

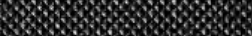

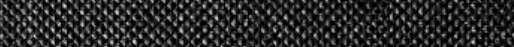

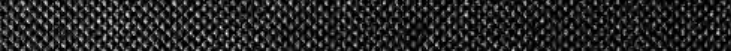

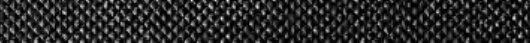

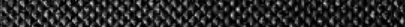

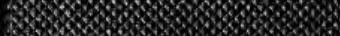

3. 